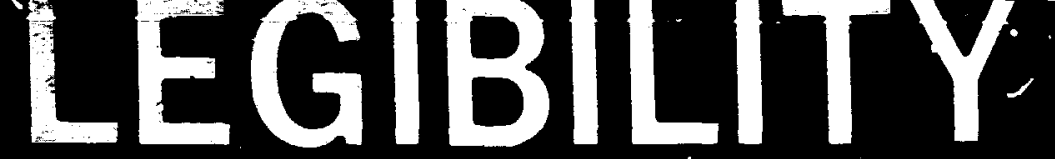

A major purpose of the Technical Information Center is to provide the broadest dissemination possible of information contained in DOE's Research and Development Reports to business, industry, the academic communit', and federal, state and local governments.

Although a small portion of this report is not reproducible, it is being made available to expedite the availability of information on the research discussed herein. 
MOTIEE

PORnONS Of THIS REPORT RRE ILLEGIBL copy to pernit the broadest pessibin no.

coility.

. OAK

RIDGE

NATIONAL

LABORATORY

UNION

CARBIDE

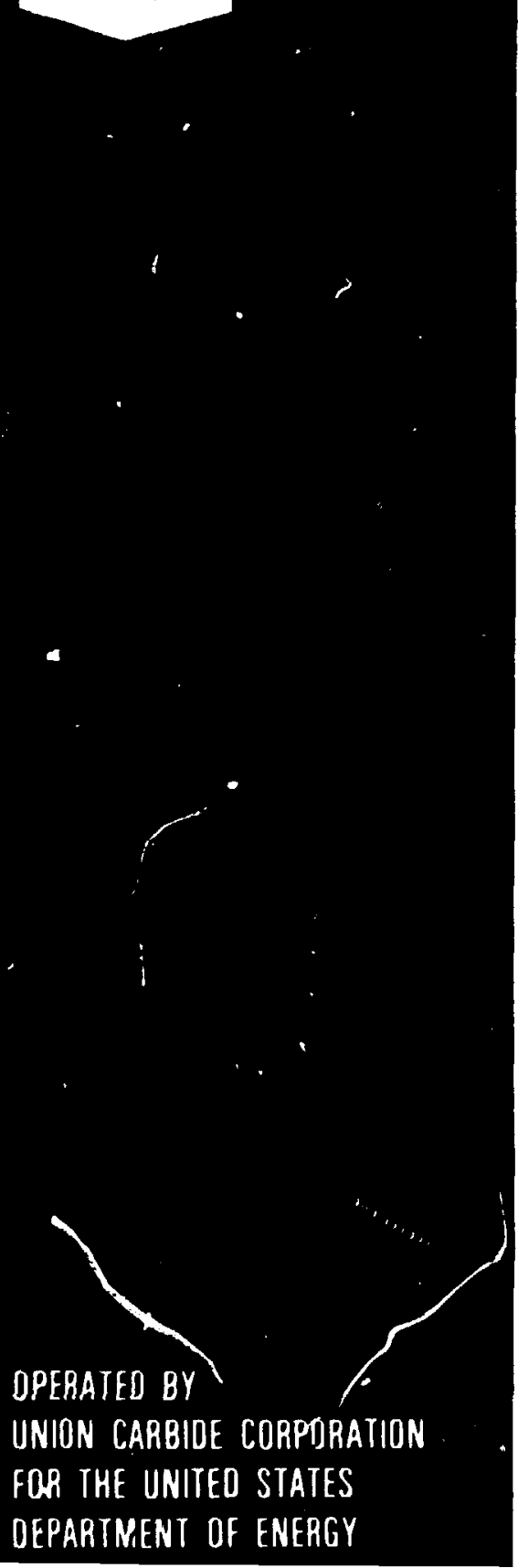

ORWL Nuclear Waste Programs Annual Progress Report for Period Ending September 30, 1982 
Printed in the United States of America. Available from National Techrical Information Service

U.S. Department of Commerce

5285 Port Royal Road. Springfield. Virginia 22161

NTIS price codes-Printed Copy: A16; Microfiche A01

This report was prepared as an account of work sponsored by an agency of the United States Government. Neither the United States Government nor any agency thereol. nor any of their employees. makes any warranty, express or implied. or assumes any legal liability or reaponsibility for the accuracy. completeness, or usefulness of any information. apparatus. product, or process disclosed. or repres:?nts that its use would not infringe privately owned rights. Reference herein to any specific commercial product. process, or service by trade name, trademark. manufacturer, or otherwise, does not necessarily constitute or imply its endorsement, recommendation, or favoring by the United States Government or any agency thereof. The views and opinions of authors expressed herein do not necessarily state or reflect those of the United States Government or any agency thereof. 


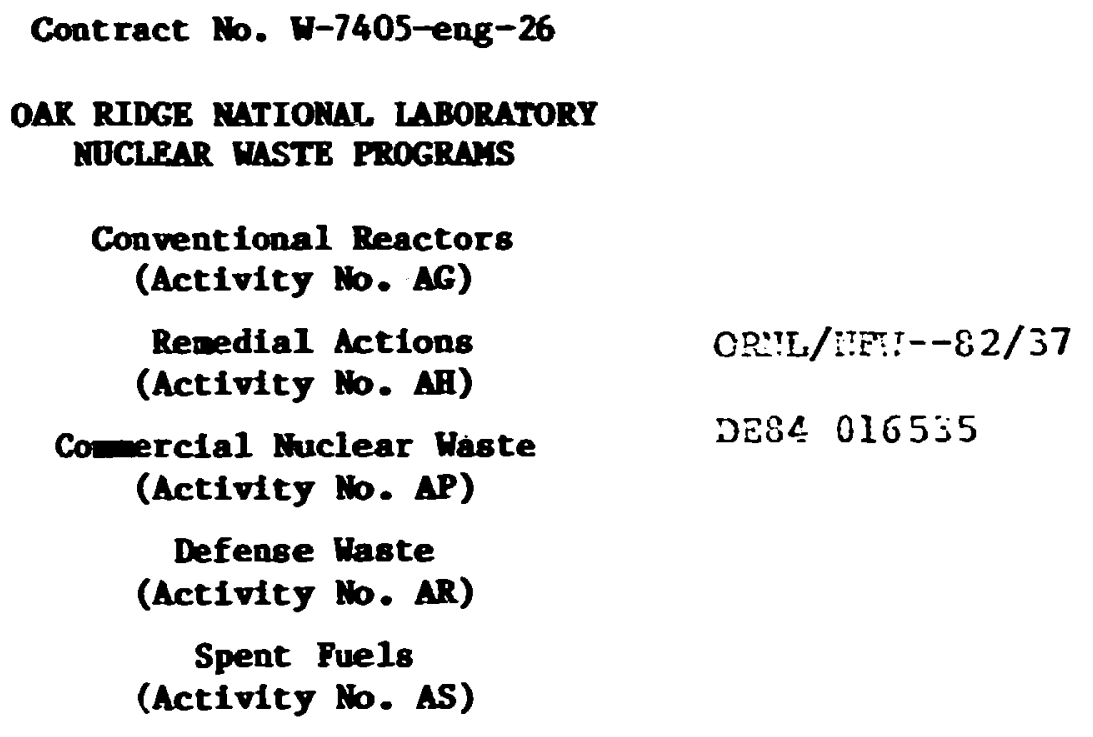

ORML NUCLEAR WASTE PROGRAMS

ANNAL PROGRESS REPORT FOR PERIOD ENDING SEPTEMGER 30, 1982

$\begin{array}{ll}\text { Program Managers: } & \text { J. H. Coobs } \\ & \text { N. H. Cutshall } \\ & \text { A. P. Malinauskas } \\ & \text { L. J. Mezga } \\ & \text { K. J. Notz } \\ & \text { H. H. PIte } \\ & \text { J. D. Sease } \\ & \text { L. J. Shappert } \\ & \text { S. H. Stow } \\ & \text { S. M. Tlegs } \\ & \text { T. H. Row } \\ \text { Program Director: } & \text { J. C. Brown } \\ \text { Finance Officer: } & \text { M. S. Cooper } \\ \text { Program Secretaries: } & \text { P. D. Viles }\end{array}$

May 1983

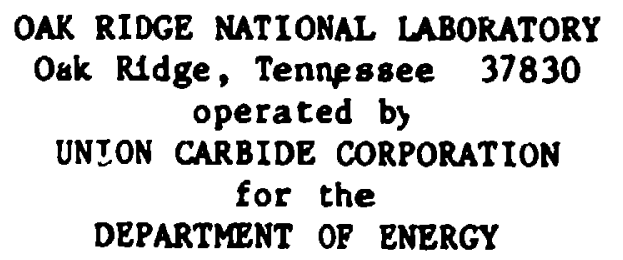




\section{DISCLAIMER}

This report was prepared as an account of work sponsored by an agency of the United States Covernment. Neither the United State Governmert mor any agency thereof, nor any of their employees, makes any warranty, express or implied, or assumes any legal liability or responsibility for the acsuracy. completeness, or usefulpess of any information, apparatus, product, or process disclosed, of represents that its use would not infringe privately owned rights. Reference herein to any specific commercial product, process, or service by trade name, trademark, manufacturer, or otherwise does not necessarily constitute or imply its endorsement, recommendation, of favoring by the United States Government or any agency thereof. The views and opinions of authors expressed herein do not necessarily state or reflect those of the United States Gowernment or any agency thereof. 


\section{SPEAT FUALS PROGRM}

1. SPENT FUELS PROGRAM - L. J. Shappert $\ldots \ldots \ldots \ldots \ldots \ldots \ldots \ldots \ldots \ldots \ldots$

1.1 IMTRODUCTION $\ldots \ldots \ldots \ldots \ldots \ldots \ldots \ldots \ldots \ldots \ldots \ldots \ldots \ldots \ldots \ldots \ldots \ldots, 3$

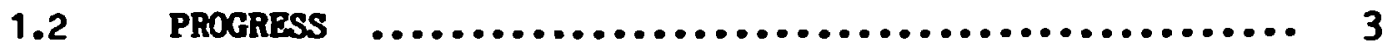

1.2.1 Spent Puel Storage $\ldots \ldots \ldots \ldots \ldots \ldots \ldots \ldots \ldots \ldots \ldots$

1.3 PUBLICATIOLS $\ldots \ldots \ldots \ldots \ldots \ldots \ldots \ldots \ldots \ldots \ldots \ldots \ldots \ldots \ldots \ldots \ldots \ldots$

$1.4 \quad$ REPERENCES $\quad \ldots \ldots \ldots \ldots \ldots \ldots \ldots \ldots \ldots \ldots \ldots \ldots \ldots \ldots \ldots \ldots \ldots \ldots$

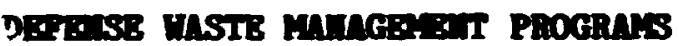

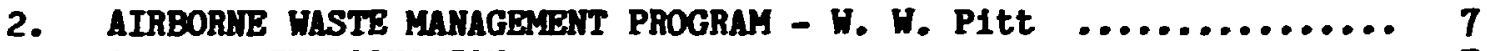

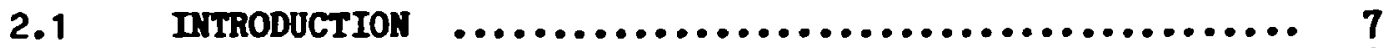

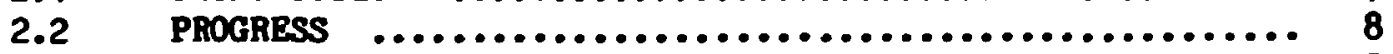

2.2.1 Carbon-14 Immobilization ................. 8

2.2.2 Filter Test Facility Quality Assurance ....... 12

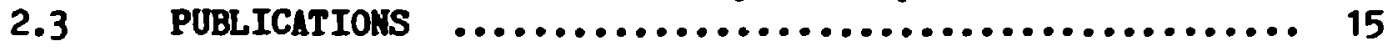

2.4 REFEREICES $\ldots \ldots \ldots \ldots \ldots \ldots \ldots \ldots \ldots \ldots \ldots \ldots \ldots \ldots \ldots \ldots \ldots \ldots \ldots . \ldots$

3. BYPRODUCTS UTILIZATION MANAGEMENT PROGRAM - S. M. TIegs ...... 17

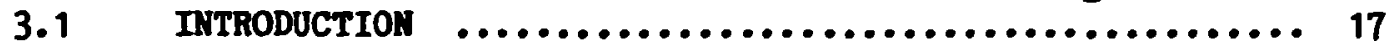

3.2 PROGRESS $\ldots \ldots \ldots \ldots \ldots \ldots \ldots \ldots \ldots \ldots \ldots \ldots \ldots \ldots \ldots \ldots \ldots \ldots \ldots . \ldots \ldots$

3.2.1 Terrestrial Radioisotope Application

Development .......................... 17

$3.3 \quad$ PUBLICATIONS $\ldots \ldots \ldots \ldots \ldots \ldots \ldots \ldots \ldots \ldots \ldots \ldots \ldots \ldots \ldots \ldots \ldots \ldots \ldots \ldots \ldots$

$3.4 \quad$ REPERENCES $\ldots \ldots \ldots \ldots \ldots \ldots \ldots \ldots \ldots \ldots \ldots \ldots \ldots \ldots \ldots \ldots \ldots \ldots \ldots$

4. SURPLUS RACILITIES MANAGERERT PROGRAM - J. H. COObs ........ 39

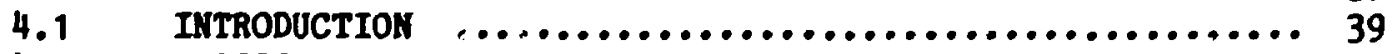

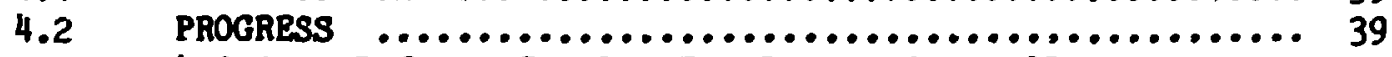

4.2.1 Defense Surplus Facilities Survelllance and

Maintenance ......................... 40

4.2.2 Curium Facility Decomissioning ............ 40

4.2.3 ILH Transfer Line Decomissioning .......... 44

$4.3 \quad$ PUBLICATIONS $\ldots \ldots \ldots \ldots \ldots \ldots \ldots \ldots \ldots \ldots \ldots \ldots \ldots \ldots \ldots \ldots \ldots \ldots . \ldots 46$

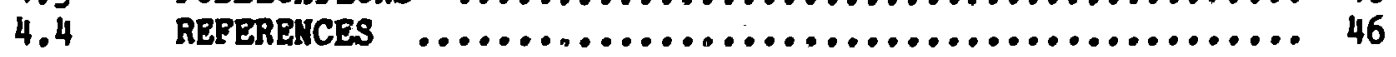

5. HIGH-LEVEL WASTE MANAGEMENT PROGRAM - W. W. Pitt $\ldots \ldots \ldots \ldots \ldots \ldots 49$

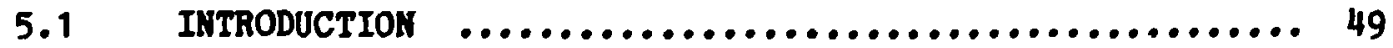

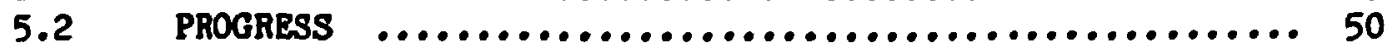

5.2 .1 Concrete Grout Bulk Immobilization Study ..... 50

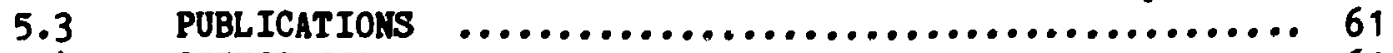

5.4 RERERERCES $\ldots \ldots \ldots \ldots \ldots \ldots \ldots \ldots \ldots \ldots \ldots \ldots \ldots \ldots \ldots \ldots \ldots \ldots \ldots \ldots 61$ 
6. INTEGRATED DATA BASE PROGRAM - . J. Notz $\ldots \ldots \ldots \ldots \ldots \ldots \ldots \ldots .63$

6.1 INTRODUCIION $\ldots \ldots \ldots \ldots \ldots \ldots \ldots \ldots \ldots \ldots \ldots \ldots \ldots \ldots \ldots \ldots \ldots . \ldots 6 . \ldots \ldots$

6.2 PROGRESS ................................... 63

6.2 .1 Integrated Data Base $\ldots \ldots \ldots \ldots \ldots \ldots \ldots \ldots \ldots 6 . \ldots \ldots$

6.3 PUBLICATIONS $\ldots \ldots \ldots \ldots \ldots \ldots \ldots \ldots \ldots \ldots \ldots \ldots \ldots \ldots \ldots . \ldots \ldots$

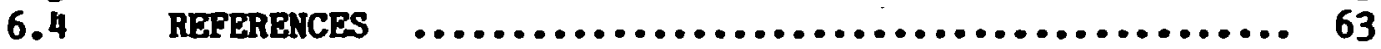

7.1 DOE LOW-LeVEL WASTE MANAGEAGNT PROGRAM - L. J. Mezga ........ 65

7.1 .1 INTRODUCTION $\ldots \ldots \ldots \ldots \ldots \ldots \ldots \ldots \ldots \ldots \ldots \ldots \ldots \ldots \ldots \ldots . \ldots 6$

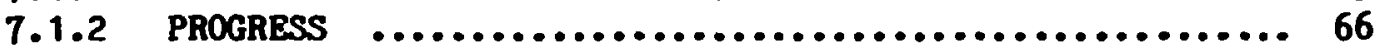

7.1.2.1 Low-Level Waste Management ...............66 66

7.1.2.2 Site Participation ...................... 66

7.1.2.3 Corrective Measures Handbook .............. 70

7.1.3 PUBLICATIOLS $\ldots \ldots \ldots \ldots \ldots \ldots \ldots \ldots \ldots \ldots \ldots \ldots \ldots \ldots \ldots \ldots . \ldots \ldots$

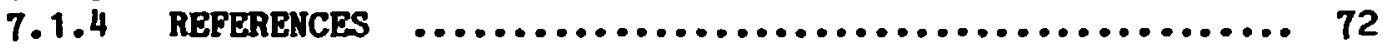

7.2 ORNL LOW-LEVEL WASTE MaNAGEMENT PROGRAM - N. H. Cutshall ..... 73

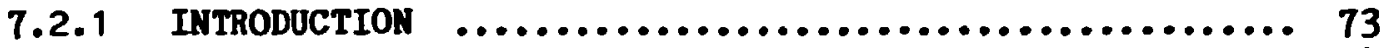

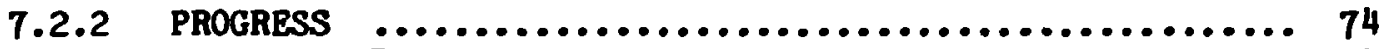

7.2.2.1 ORNL Corrective Measures ............... 74

7.2.2.2 Shallow Land Burial Technology

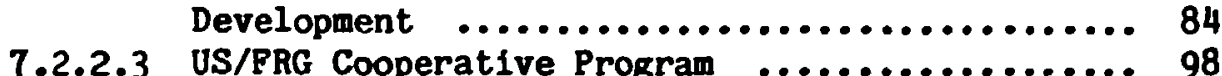

7.2 .2 .4 Decontamination Effectiveness .............. 98

7.2.2.5 Shallow Land Burial Handbook ............. 99

7.2.2.6 Low-Level Waste Treatment

Handbook ............................... 100

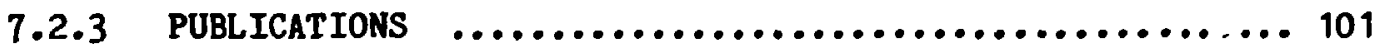

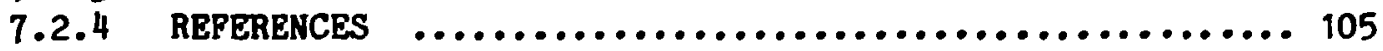

8. WASTE MANAGEMENT OPERATIONS PROGRAM - J. D. Sease .......... 107

8.1 INTRODUCTION $\ldots \ldots \ldots \ldots \ldots \ldots \ldots \ldots \ldots \ldots \ldots \ldots \ldots \ldots \ldots \ldots \ldots$

$8.2 \quad$ PROGRESS $\ldots \ldots \ldots \ldots \ldots \ldots \ldots \ldots \ldots \ldots \ldots \ldots \ldots \ldots \ldots \ldots \ldots \ldots$

8.2.1 Operational Planning and Development ........ 108

8.2.2 Liquid and Gaseous Waste System Operations ... 142

8.2.3 Solid Waste Storage Management ............ 146

8.2.4 Gunite Tank Sludge Removal Project .......... 152

8.2.5 Site Specific Low-Level Waste Studies ....... 157

8.2.6 Hydrofracture Mix Development Studies ....... :78

8.2.7 Waste Volume Reduction .................. 186

8.2.8 Central Waste Disposal Pacility Design

and Development ...................... 199

8.2.9 Metal Haste Management at ORO Sites ......... 206

8.2.10 Traffic Managers Support ................. 209

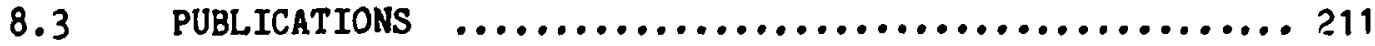

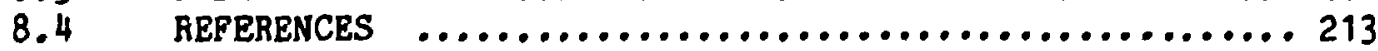




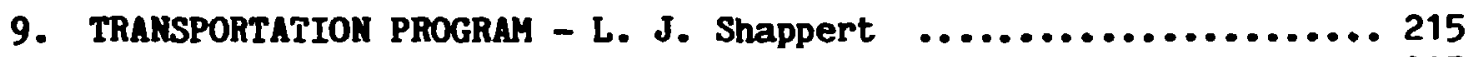

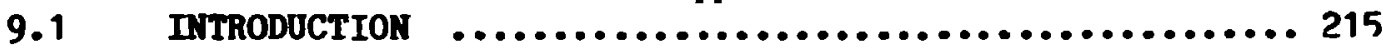

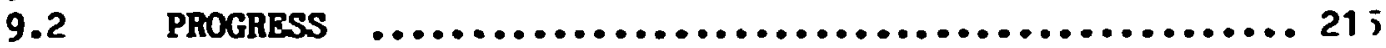

9.2.1 Defense Waste Transfortation Studies ........ 215

9.2.2 TRUPACT Transport System Tests ........... 217

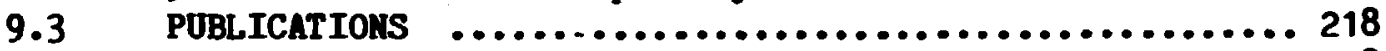

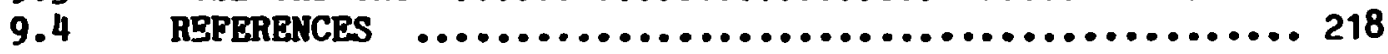

10. TRU HASTE MANAGEMENT PROGRAM - H. H. Pitt $\ldots \ldots \ldots \ldots \ldots \ldots \ldots \ldots . \ldots \ldots$

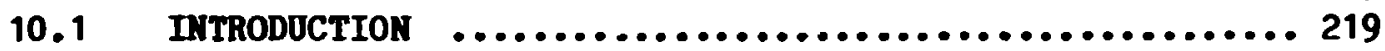

10.2 PROGRESS ..................................... 219

10.2.1 FUETAP Concrete Immobilization $\ldots \ldots \ldots \ldots \ldots \ldots 219$

10.2.2 Instrumentation Prototype ................ 225

10.2.3 TRU Naste Certification Program ............ 228

10.2.4 Cementitious Waste Form Development for

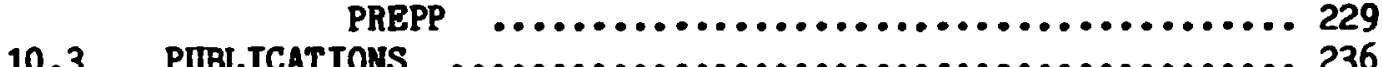

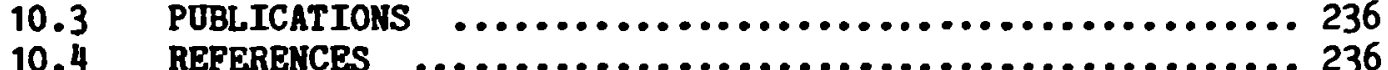

\section{COAGRCIAL MUCLEAR UASTE MATLGBiET PROGRAYS}

11. HIGH-LEVEL HASTE MANAGEMENT PRUGRAM - H. H. Pitt ........... 239

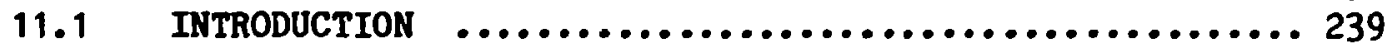

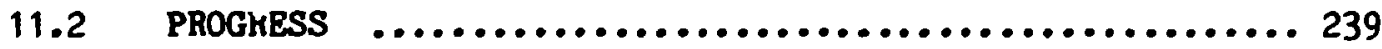

11.2.1 ORNL Fixation of Waste in Concrete .........239

11.2.2 High-Level Waste Container Development ...... 255

11.2.3 ORNL Sol-Gel Coated Particle Waste Form

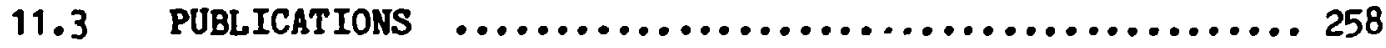

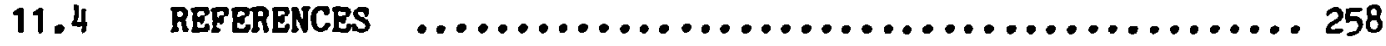

12. INTEGRATED DATA BASE PROGRAM - K. J. Notz ............... 259

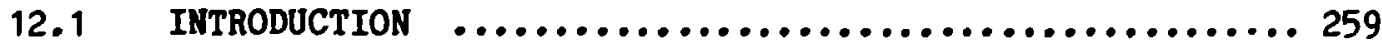

12.2 PROGRESS ................................... 259

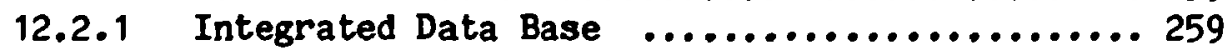

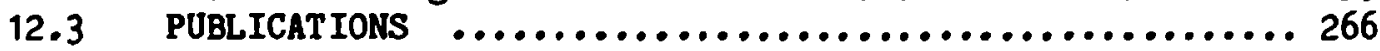

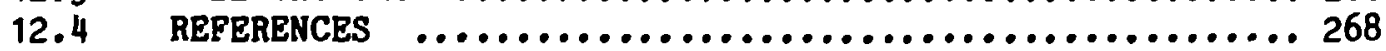

13. LOW-LeVEL haSte MANAGEMENT PROGRaM-L. J. Mezga/N. H. Cutshall... 269

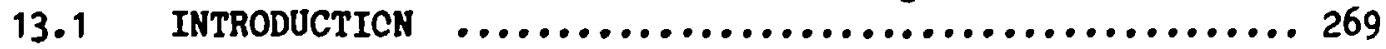

13.2 PROGRESS .................................. 269

13.2.1 Low-Level Waste Information Center .........269

13.2.2 State Screening Project ................. 270

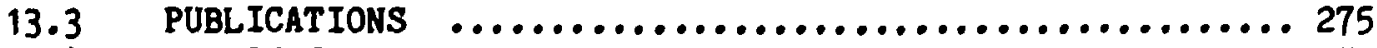

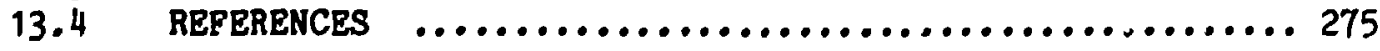


14. TRARSPORTATION PROGRAM - L. J. Shappert .................. 277

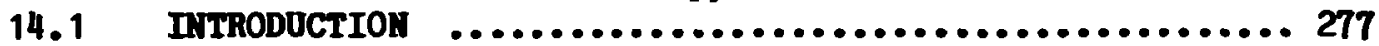

14.2 PROGRESS ..................................... 277

14.2.1 Comercial Waste Transportation Studies ..... 277

14.3 PUBLICATIOLS ................................. 279

14.4 REPERENCES $\ldots \ldots \ldots \ldots \ldots \ldots \ldots \ldots \ldots \ldots \ldots \ldots \ldots \ldots \ldots \ldots \ldots \ldots \ldots \ldots . \ldots 279$

15. TRU wASTE managengNT PROGRAM - H. H. Pitt $\ldots \ldots \ldots \ldots \ldots \ldots \ldots \ldots \ldots 281$

15.1 INTRODUCTION $\ldots \ldots \ldots \ldots \ldots \ldots \ldots \ldots \ldots \ldots \ldots \ldots \ldots \ldots \ldots \ldots \ldots . \ldots . \ldots \ldots 1$

15.2 PROGRESS .................................... 281

15.2.1 FUETAP Concrete Imnobilization ............ 281

15.2.2 TRO Comercial Fuel Cycle Studies ..........281

15.2.3 TRU Isotope Decay Chains .................. 284

15.3 PUBLICATIONS .................................. 289

15.4 REFEREHCES $\ldots \ldots \ldots \ldots \ldots \ldots \ldots \ldots \ldots \ldots \ldots \ldots \ldots \ldots \ldots \ldots \ldots \ldots \ldots \ldots . \ldots . \ldots$

16. WASTE ISOLATION PROGRAM - S. H. Stow $\ldots \ldots \ldots \ldots \ldots \ldots \ldots \ldots \ldots \ldots \ldots 1$

16.1 INTRODUCTION $\ldots \ldots \ldots \ldots \ldots \ldots \ldots \ldots \ldots \ldots \ldots \ldots \ldots \ldots \ldots \ldots \ldots \ldots . . \ldots 291$

16.2 PHOGRESS ..................................... 291

16.2.1 Regional Environmental Characterization

Studies - Nuclear Haste ................... 291

16.2.2 Institutional Arrangements for Nuclear

Waste Siting ........................... 292

16.2.3 Evaluation of Avery Island Coupons ..........293

16.2.4 Effects of Water in Salt Repositories ........ 293

16.2.5 Salt Model Pillar Studies ................. 294

16.2.6 Expected Repository Environments for

Commercial Wastes, Savannah River Hastes,

and Other Wastes ........................ 295

16.2.7 Technical Topical Report on Brine

Migration ............................. 295

16.2.8 System Model to Assess Flooding in a

Waste Repository ........................ 296

16.2.9 Sensitivity and Uncertainty Analysis

Methods Development ..................... 296

16.3 PUBLICATIOAS $\ldots \ldots \ldots \ldots \ldots \ldots \ldots \ldots \ldots \ldots \ldots \ldots \ldots \ldots \ldots \ldots \ldots \ldots . \ldots \ldots$

16.4 REPEREICES $\ldots \ldots \ldots \ldots \ldots \ldots \ldots \ldots \ldots \ldots \ldots \ldots \ldots \ldots \ldots \ldots \ldots \ldots \ldots . \ldots . \ldots . \ldots . \ldots . \ldots$

\section{REISDIN ICTIOIS PROGRAYS}

17. SURPLUS PACILITIES MANAGEARNT PROGRAM - J. H. Coobs ......... 303

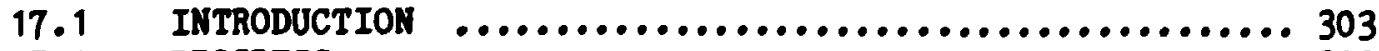

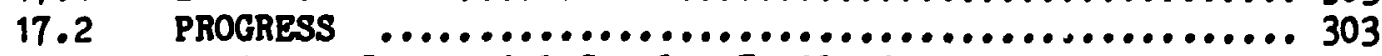

17.2.1 Comercial Surplus Pacilit'es

Survelllance .......................... 303

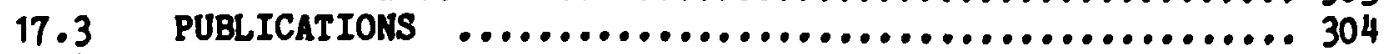

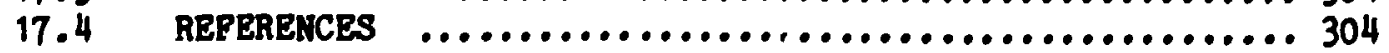


18. URANTUM MILL TAILTMGS PROGRAM - J. H. Coobs ............... 305

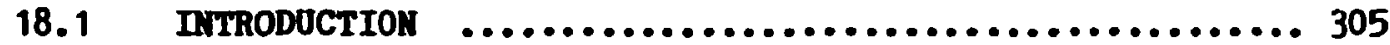

18.2 PROGRESS .................................... 305

18.2.1 Liner Evaluations for Uranium Mill

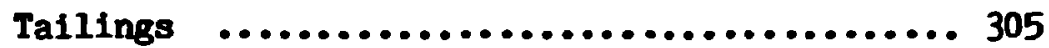

18.2.2 UMrRAP Information Support $\ldots \ldots \ldots \ldots \ldots \ldots \ldots \ldots . \ldots \ldots$

18.3 PUBLICATIOLS $\ldots \ldots \ldots \ldots \ldots \ldots \ldots \ldots \ldots \ldots \ldots \ldots \ldots \ldots \ldots \ldots \ldots \ldots . \ldots . \ldots \ldots$

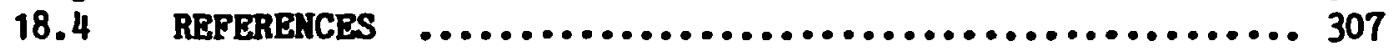

19. FORMERLY UTILIZED SITES REMEDIAL ACTIONS PROGRAM - W. W. Pitt... 309

19.1 INTRODUCTION $\ldots \ldots \ldots \ldots \ldots \ldots \ldots \ldots \ldots \ldots \ldots \ldots \ldots \ldots \ldots \ldots \ldots . \ldots 309$

19.2 PROGRESS ...................................... 309

19.2.1 Stabilization Studies at Middlesex,

New Jersey Sampling Plant ................ 309

19.3 PUBLICATIOHS ................................ 315

19.4 REREREKCES $\ldots \ldots \ldots \ldots \ldots \ldots \ldots \ldots \ldots \ldots \ldots \ldots \ldots \ldots \ldots \ldots \ldots \ldots$

CONVEITIONL RBACTOR PROGRAY

20. THREE-MILE ISLAND PROGRAM - A. P. Malinauskas ............. 321

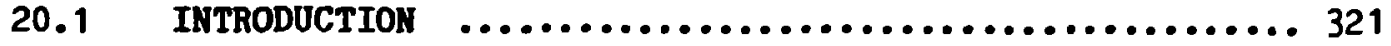

20.2 PROGRESS .................................. 321

20.2.1 Technical Advisory Grour Activities ......... 321

20.2.2 Technical Assistance and Advisory Group

Activities ............................. 322

20.2.3 Technical Support Activities .............. 322

20.2.4 Development of Inorganic Sorbents ........... 326

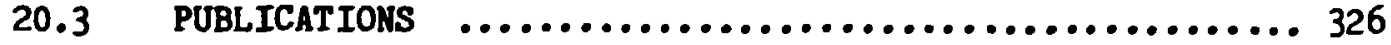

20.4 REFERENCES $\quad \ldots \ldots \ldots \ldots \ldots \ldots \ldots \ldots \ldots \ldots \ldots \ldots \ldots \ldots \ldots \ldots$ 
HIGHLIGHTS

\section{SPENT FUELS PROGRAM}

A catalog was drafted and submitted to the Transportatio:t Technology Cent‘.r, Sandia National Laboratories for their review and approval covering such topics as federal, state, and local regulations, spent fuels characteristics, cask characteristics, transportation costs, and emergency response information.

\section{AIRBORNE WASTE MANAGEMENT PROGRAM}

\subsubsection{Carbon-14 Immobilizatiou}

Carbon- 14 immobilizazion development studies on the $\mathrm{Ba}(\mathrm{OH}) 2 \cdot 8 \mathrm{H}_{2} \mathrm{O}$ process have been completed. These studies were conducted at the micro-, bench-, and pilot-8cale and will be the subject of two final reports, which are in preparation.

\subsubsection{Filter Test Fac1lity Quality Assurance}

Three meetings of the Filter Test Facilities (FTF) Standards Wricing Group were held, one at each facility. Final drafts of two standards were completed. Work began on preliminary drafts of two additional standards.

\section{BYPRODUCTS UTILIZATION MANAGEMENT PROGRAM}

S1x major fleld tests of the radiolumfnescent lights were conducted this year in concert with development and fabrication. The fleld tests provided Input from various Department of Defense services and the program expanded to include infrared 11 ghts and afrcraft instrument lighting. Important Imprc nts were made to the luminescent lights light output by proper selection or phosphors, application of phosphors to the tubes, tube geometry, and geometry of assembled fixtures. 
A cesium-137 WESF cafsule used in the Sandia sludge irradiator was examined for internal corrosion and capsule tensile strength.

Solubility testing of fully active cesium pollucite was completed.

\section{SURPLUS FACILITIES MANAGEMENT PROGRAM}

\subsubsection{Defense-Surplus Facilities Surveillance and Maintenance}

At the Metal Recovery Facility, defective roof hatches were replaced, radionuclide content of the canal was monitored, and a complete report on radiological characterization of the facllity was issued. The stack was cleaned and cleared of debris at the ORNL Graphite Reactor in addition to regenerating demineralizer and routine filter replacements.

\subsubsection{Curium Facility Decommissioning}

Decontamination of the manipulator cells in the Curfum Facility was completed by using a combination of Lechniques. Contamination levels in the cells are acceptable for the planned alternate use of the facility.

\subsubsection{ILW Transfer Line Decommissioning}

The abandoned transfer lines across the White Oak Creek floodplain and the high-pressure line from the old hydrofracture to the New Hydrofracture Facility were excavated and removed. The high-pressure pipe was salvagec and stored for reuse, and the abrndoned pipeline was disposed of as waste.

\section{HIGH-LEVEL WASTE MANAGEMENT PROGRAM}

\subsubsection{Concrete Grout Bulk Immobilization Study}

ORNL demonstrated the feasibility of using grout bulk solidification for Hanford tank sludges and newly generated Purex wastes. Work is proceeding to establish the necessary grout formulations for specific wastes and to determine the properties of the resulting grouts. 


\section{INTEGRATED DATA BASE PROGRAM}

A new issue of the annual report on spent fuel and radwaste Inventories, projections, and characteristics was published, projecting to year 2020 and assuming reprocessing and defense HW vitrification. Development of ORGENTRE-8ystem codes continued for (a) nuclear materidis (fissile and fertile) in the overall fuel cycle, (b) defense and I/I projections, and (c) waste treatment simulation. The ORIGEN 2 code for Isotope generation and depletion was maintained and updated for once-through fuel cycles. Bibliographic files were expanded and a bibliography published. The "Radioactive Waste Management Vewsletter" was pubilished (issues $15,16 / 17$, and 18 ).

\subsection{DOE LOW-LEVEL WASTE MANAGEMENT PROGRAM}

During FY 1982, the LLWMP Program Office at ORNL has drafted technology program plans, developed prioritized FY 1982, FY 1983, and FY 1984 budgets to support these plans, and provided technical guidance for the implementation of these plans at participating DOE sites.

\section{WASTE MANAGEMENT OPERATIONS PROGRAM}

\subsubsection{Operatlonaj Planning and Developmist}

An ad hoc committee for development of a long-range plan for radioactive waste management completed a draft report that describes the various waste systems, discusses problems and shortcomings, and recommends improvements in factifties and practices. The committee's report will be issued in two parts during FY 1983. 
The New Hydrofracture Facility was completed. A dedication ceremony was held, and the facility became operational in June. Construction of the new building for the Waste Operations Control Center was completed, and a contract for procurement of the data acquisition system was negotiated. Demolition of the old precipitator at the 3039 Stack Off-Gas System and modifications to the scrubber were completed, and construction of the temporary by-pass loops is in progress. Major construction at the new flow monitoring station No. 3 on White Oak Creek was completed, and work on the other two stations is progressing on schedule. Progress on General Plant Projects included completion of four clusters of piezometer wells in SWSA 5 and a monitoring weir for the Northwest Tributary of White 0ak Creek. Installation of the electropolishing equipment at FPDL was completed and a core storage building was constructed. Procurement and installation of a fourth column for the Process Waste Treatment Plant has been delayed because the column dfd not pass inspection and testing.

\section{Liquid and Gaseous Wastes System Operations}

After preoperational testing, including a cold injection in March, the: New Hydrofracture Facility (NHF) began hot operation in June with injection of about $606 \mathrm{~m}^{3}(160,000 \mathrm{gal})$ of concentrated intermediatelevel waste. Also, two injections of resuspended gunite tank sludge were made: In August about $696 \mathrm{~m}^{3}(184,000 \mathrm{gal})$ and in September about $454 \mathrm{~m}^{3}$ $(120,000 \mathrm{gal})$. 


\subsubsection{Solid Waste Storage Management}

About $54 \mathrm{~m}^{3}\left(1,910 \mathrm{ft}^{3}\right)$ of TRU waste were stored retrievably. About $1,886 \mathrm{~m}^{3}\left(66,563 \mathrm{ft}^{3}\right)$ of beta-ganma waste were recr.ived: $1,404 \mathrm{~m}^{3}$ $\left(49,598 \mathrm{ft}^{3}\right)$, Including $34 \mathrm{~m}^{3}$ which was $278 \mathrm{~m}^{3}$ before compaction, were buried in trenches and auger holes and $238 \mathrm{~m}^{3}\left(8,403 \mathrm{ft}^{3}\right)$ in landfill for low-hazard contaminated wast $\geqq$.

\subsubsection{Gunite Tank Sludge Removal Project}

Construction of the gunite tank sludge removal project was completer. Necessary documents were prepared, reviewed and approved. Preoperational testing was completed and sluicing began on June 12. As noted above, two injections of resuspended sludge were made at the NHF: In August, about $696 \mathrm{~m}^{3}(184,000 \mathrm{gal})$ a:d in September about $454 \mathrm{~m}^{3}(120,00 \mathrm{gal})$.

\subsubsection{Site Specific Low-Level Waste Studies}

A detalled site characterization of the geochemical, hydrological, and geological factors governing radionuclide migration is presently being undertaken at ILW Trench 7. This site was chosen because of the occurrence of ${ }^{60} \mathrm{Co}$ and ${ }^{233} \mathrm{U}$ in a surface seep which appears in a valley $50 \mathrm{~m}$ east of

the trench. Groundwater ${ }^{60} \mathrm{Co}$ and ${ }^{233} \mathrm{U}$ concentrations undergo a seasonal variation at this site with the highest activities occurring in the springtime. The seasonal rise in niclide ac: the groundwater level and a concurrent increase in groundwater $\mathrm{pH}$. This suggests that during winter and spring, the water table may rise to saturate the alkaline fill in the trench or contaminated solis near the trench and thus promote nuclide migration. A new serfes of wells and soll borings is presently being drilled at the north end of the trench to evaluate the above mechanism and pathway for nuclide moblifzation and 
transport and the effectiveness of the groundwater interceptor drain as a remedial action plan to retard nuclide : ransport along this pathway. Since SWSA 4 is the most important contributor of ${ }^{90} \mathrm{Sr}$ to White Oak Creek, it has been the focus of detailed studies of mechanisms for the hydrologic transport of ${ }^{90} \mathrm{Sr}$ from disposal trenches. These studies have shown that surface runoff is of major importance at SWSA 4 and have resulted in plans for a surface water diversion to capture uncontaminated runoff from the upslope portions of the SWSA 4 watershed and divert it. In the meantime, soil and water samples have been taken to characterize the nature and extent of radionuclide contamination that is potentially susceptible to transport by groundwater runoff. The nature of the threedimensional distribution pattern strongly suggests that the spread of contamination results from the "bathtub" effect within several individual trenches in low-lying areas. These trenches, which were constructed perpendicular to contour liues, collect water and overflow to the grourd surface at the downslope end rather than releasing contaminated water to the surrounding soils for subsequent groundwater transport. It is expected that this shortened pathway will be reduced to a minor role when the surface water diversion construction is completed. Dye tracer experiments have confirmed that SWSA 3 is the source of radiostrontium to seeps on Raccoon Creek and the Northwest Tributwry (NWT) to White Oak Creek. The relative intensity of dye reaching the NWT and the Raccoon Creek seep indicates that a spring on the NWT is the major recipient of radionuclides migrating from SWSA 3. This spring should be an excellent monitoring point for assessing the effectiveness of any remedial actions implemented at SWSA 3. This work is of particular significance because SWSA 3 overlies a limestone formation that is known to contaln solution openings. 


\subsubsection{Hydrofracture Mix and Grout Development Studies}

Studies showed no difference between the performance of the suspending agent Attagel-350 and the Attapulgite-150 drilling clay in hydrofracture grouts.

Dry solids blending tests showed the necessity of homogenious blending to assure acceptable grout rheologies.

Microscopic examination of an 18 year old grout core showed no radionuclide migration into the shale.

\subsubsection{Waste Volume Reduction Operations}

Two mezhods of dissolution of the aluminum metal-europium oxide HFIR control plates were tested successfully.

An electropolisher and a vibratory finisher were installed at the ission Product Development Laboratory to decontaminate metallic tools and small equipment for reuse at ORNL facilitfes or for salvage operations. The reduction in the volume of tnis type of material presently sent to the burial ground will aid in the conservation of the limited burial ground space available at ORNL.

Láboratory studies indicate viability of using anaerobic digestion technology for volume reduction of low-level solid radioactive waste generated at ORNL. The volume reduction factor for this process is expected to be approximately $20: 1$.

\subsubsection{Central Waste Disposal Factlity Design and Development}

A single large area on West Chestnut Ridge, near ORNL, was selected as the reference site for a central waste facility for LLSRW disposal. Preliminary field studies (geological, hydrologizal, and selsmic refraction) were completed on six topographically attractive tracts. As a result of these studies, a decision was made to continue examining 
this site with more detailed field studies. Because the reference site could not yet be accepted with a high degree of confidence, however, a decision was maje to select an additional, alternative site on which to begin preliminary field studies.

For ORNL, the central waste facility will complement SWSA 7, the solid waste storage area being developed for low-volume, higher-activity solid waste.

\subsubsection{Metal Waste Management at ORO Sites}

The Conceptual Design Requirements for a Metal Smelting Facility report was completed during FY 1982. Various disposal options for the ORGDP scrap metal were also investigated and a complete report was issued. Work was completed and a report was issued which detailed the potential need within the government for the steel produced from suelting of the contaminated scrap metal. An additional study has been completed, and a report issued, that investigated processing the contaminated scrap metal using comercial metal processing and smelting firms for both on-site and off-site operations.

\subsubsection{Traffic Managers Support}

\section{A Transportation of Hazardous Materials: Directory of Principal} Contacts was developed designating the agencies/personnel responsible for transporting hazardous/radloactive materials and emergency response contacts for each state and locale.

The data base for the HIGHWAY routing model has been upgraded to include principal DOE sites, nuclear reactors, and major comercial airports. A special program has been developed for Identifying the afrports in the vicinity of any location included in the HIGHWA data base. 


\section{TRANSPORTATION PROGRAM}

\subsubsection{Defense Waste Transportation Studies}

The Legislative and Regulatory Information System was divided into a current and a historic data base, both of which were converted to the new data management system, INQUIRE. The Seventh International Symposium on Packaging and Transportation of Radioactive Materials has been scheduled in New Orleans, Louisiana, in May 1983. Instructions for the preparation of papers have been completed. A study to compare the use of various criticality codes by the International Committee was completed and results indicated that codes employing Monte Carlo and other transport methods give satisfactory results.

\subsubsection{TRUPACT Transport System Tests}

Newly designed TRU waste packages, intended to be carried in the TRUPACT container (an overpack currently being designed by the Trans.. portation Technology Center at Sandia National Laboratory) were impact tested under conditions spectfied in DOE and NRC rezulations.

\section{TRU WASTE MANAGEMENT PROGRAM}

\subsubsection{FUETAP Concrete Immobilization}

The first PUETAP process proof-of-principal tests at an engineering scale $(1 / 4-t o n)$ was successfully completed.

ORNL formulated and tested a cement-based waste host from the Rocky Flats Plant Rullding 374 sludges. 
xvii

\subsubsection{Instrumentation Prototype}

To date 114 drums have been assayed and gamma-scanned by the NIAS and segmented drum scanner, respectively. We have tentatively identified 46 drums as being below the $100 \mathrm{n} \mathrm{Ci} / \mathrm{g}$ limit for TRU waste and 55 drums as being over the limit. Maximum throughput of drums in the active and total colncidence neutrons assay modes (not Including neutron iliplicity measurements and gamma-scanning) was found to be six to seven druns per hour (40-50 drums per 8-hr shift) with sufficient personnel and equipment.

Destructive assaying of the drums will entail the transfer of a drum's contents into a glove box for examination, segregation of waste type, shredding of cellulosics, and plastics, and sampling for gamma-ray spectroscopic analysis. It is planned to assay approximately 100 drums taking approximately 100 samples from each drum.

\subsubsection{TRU Waste Certification Program}

A certification document for handling newly generated contact handled transuranic waste at ORNL was completed and internally reviewed. All of the certifiration document, except the detalled site handing procedures, has been in: ormally submitted to TWSO for comment.

\subsubsection{Cementitious Waste Form Development for PREPP}

Preliminary formulas for high- and low-combustible ashes from the PREPP at INEL were formulated and proof-of-principle tests of the cementation step were supported on site. Recommendations regarding mixing equipriant and accelerated terting for the cemented wastes were made. 
xvili

11. HIGH-LBVEI, WASTE MANAGERTT PROGRAM

\subsubsection{ORML PIxation of Hastes in Concretes}

A draft of the close-out evaluation report on the use of autoclaved concretes for high-level wastes was prepared.

\section{INTEGRATED DATA BASE PROGRAM}

\subsubsection{Integrated Data Base. Progran}

A new Igsue of the annual report on spent fuel and radwaste Inventories, projections, and characteristics was published, projecting to year 2020 and assuning reprocessing and defense BLW vitrification. Developwent of ORGENTRE-8ystem codes continued for (a) nuclear materials (fissile and fertile) In the overall fuel cycle, (b) defense and I/I projections, and (c) waste treatment simulation. The ORIGEN 2 code for 1sotope generation and depletion was maintained and updated for once-through fuel cycles. Bibllographic files were expanded and a blbllography published. The "Radioactive Waste Management Newsletter" was published (18sues 15, 16/17, and 18).

\section{LOW-LEVEL WASTE MANAGEMENT PROGRAM}

\subsubsection{Low-Level Waste Information Center}

The low-level waste information center recelved 200 new documents, wrote 150 abstracts, and responded to 300 information requests on technical information relevant to low-leve 1 radioactive waste technology during the funding period October 1, 1981 to February 1, 1982. 


\subsubsection{State Screening Project}

A report has been drafted for the State of Tennessee describing a process of identifying areas that have the greatest probability of containing acceptable sites for shallow land burial of low-level radioactive waste.

\section{TRANSPORTATION PROGRAM}

\subsubsection{Comerclal Waste Transportation Studies}

Approximately 400 new bills pertalning to the transportation of radioactive materials were added to the Legislative Data Base.

The Test and Evaluation Facility Logistics Study was completed for the Transportation Technology Center, Sandia National Laboratories. The NUS waste management model RAWSYM was successfully transferred to and tested on the ORNL computer system.

\section{TRU WASTE MANAGEMENT PROGRAM}

\subsubsection{TRU Comerclal Fuel Cycle Studies}

TRU wastes to be expected from the commercial reprocessing of LWR fuel were Identified and quantitatively listed, based on an AGNS-type flowsheet, and for a $1500 \mathrm{MJU} / \mathrm{y}$ plant. Isotoplcs were based on 16 year old fuel at an average burnup of 25,200 MNd/MTHM. Qualitative differences for the reprocessing of UYPBR fuel were identified.

\subsubsection{TRU Isotope Decay Chaing}

The detalled alpha decay behavior of 38 isotopes, including daughters, were computed and summed using ORIGEN2. The results were then summarized and presented graphically for the time span 0.1 to $10^{6} \mathrm{y}$. 


\section{WASTE ISOLATION PROGRAM}

\subsubsection{Regional Environmental Characterization Studies - Nuclear Waste}

This task supports the ONWI overall goal of providing a significant degree of assurance that high-level nuclear wastes can be isolated from the biosphere in a safe and environmentally acceptable manner.

Information contained in the regional environmental characterization report was used to screen geologic formations which have potential as high-level nuclear waste repositories to select formations suitable for further detailed analyses in the area phase of this study.

\subsubsection{Institutional Arrangements for Nuclear Waste Siting}

There is considerable uncertainty that remains in the repository design and siting process indicating a need for continued research to lessen uncertainty, and flexibility in job training program design as uncertainty is reduced. There are likely to be multiple major factors that need to be involved in job training program design. There is a need for development of mechanisms for resolving potential conflicts among these major actors. Program design and implementation decisions need to be documented carefully to protect each program participant's interest. A clear assignment of responsibilities for program design and implementation must be made.

\subsubsection{Evaluation of Avery Island Coupons}

Tests to obtain the necessary corrosion data so that various multibarrier waste package emplacement concepts in domal salt could be evaluated were performed and showed that only carbon steel experienced appreciable attack. 


\subsubsection{Effects of Water in Salt Repositories}

Through experimental and modelling studies, we are attempting to predict the consequences of the presence of water in a salt repository that might compromise the integrity of the repository. At this time, testing is not complete.

\subsubsection{Salt Mode1 Pillar Studies}

Careful examination of the creep records of the long-term tests revealed the existence of episodes of transient creep occurring between periods of steady behavior. The potential importance of these transient creep episodes in repository design and in the verification of computer codes to be used in design justified a more in-depth investigation.

\subsubsection{Expected Repository Environments for Comuercial Wastes, Savannah} River, and other Wastes

A series of reports has been issued describing the environments providing information in designing experiments aud repositories and in licensing proc' Jures based on calculated expected repository environments for the disposal of both commercial and defense high-level wastes and spent fuel in salt formaticns.

\subsubsection{Technical Topical Report on Brine Migration}

A report was issued describing the technical findings on brine migration in a sait repository as input to a licensing topical report.

\subsubsection{System Model to Assess Flooding in a Waste Repository}

In order to develop the methodology and appropriate computer codes for analyzing the effects of freshwater intrusion into a salt repository for nuclear waste that also has applicabflity for other geologic media, salt dissolution mechanisms were examined and the sequence of solutioning 
was divided into two phases. Models for the two phases were identified. The literature on leaching of radionuclides was examined ani appropriate models were identified. Evaluation of the experimental data on the permeability of crushed salt as a function of time whil $z$ being stressed was completed. Considerable progress was made on developing a computer code for simulating the flooding process. This code (REFS) will be based on the existing code HYTAQ.

\subsubsection{Sensitivity and Uncertainty Analysis Methods Development}

Development of the GRESS computer language to automatically calculate the sensitivities of waste repository model performance with respect to model data results will be central to the development of a comprehensive methodology for sensitivity and uncertainty analysis for waste repository design licensing. This task began in June 1981 with the development of a demonstration version of the GRESS automated language approach to adjoint sensitivity analysis. The program was halted September 30,1981 , with the completion of GRESS Verions A. After an evaluation, plans were made for full-scale development and implementation of this approach for repository design licensing.

\section{SURPLUS FACILITIES MANAGEARNT PROGRAM}

\subsubsection{Comercial Surplus Facilities Survellance}

The annual reheat of the fuel in the rolten Salt Reactor Experiment (MSRE) was completed in addition to routine inspection and changing of filters. A radiological survey of the Homogeneous Reactor Experiment (HRE-2) was inftiated and completed except for soll core samples. A leaking shield plug previously used for a loop experiment at the Oak Ridge Reactor (ORR) was replaced; the defective shield was disposed of as waste. 
xariii

\section{MILL TAILINGS PROGRAM}

\subsubsection{Liner Evaluations for Uranium Mil1 Tailings}

A draft report was completed on the assessment of in situ grouting as an alternate remedial action for will tallings piles. The topical report will be issued as soon as internal review is complete.

\subsubsection{UMRAP Information Support}

Information support was supplied to an Internal Symposium and by responding to special requests. A third volume of the bibliography entitled "Nuclear Facility Decomissioning and Site Remedial Actions" was prepared and 1ssued.

\section{FORFERLY UTILIZED SITES REMEDIAL ACTIONS PROGRAM}

The concept of In situ stabilization has been proposed for both the Middlesex Sampling Plant Site and other facllities under FUSRAP. Expressed In the nost simplified manner, this roncept envisions utflizing the natural materials (soll, other sediments, bedrock where applicable) at a site to contain the radionuclides present in contand nated material. This can be possibly accomplished by elther adnding these natural earth warerials with the wastes or burying the wastes wthin an "envelope" provlded by the natuzal materials. In some cases, both adinfing and burlal can be practiced to assure containment. In a related approach, various substances or additives, efther natural such as bentonite or artificial such as lon-exchange resins, can be added to further the contalnment capabilities of the natural materials avallable at a given site. 
xxiv

\section{THREE MILE ISLAND PROGRAM}

\subsubsection{Technical Advisory Group Activities}

The Technical Advisory Group activitles focused on the performance of the Submerged Demineralizer System for containment bullding and reactor coolar: system water cleanup. A number of other problems involving aqueous stream decontamination were also addressed.

\subsubsection{Technical Assistance and Adv1sory Group}

Participation on TAAG Involved reviews of many significant TMI-2 recovery operations including the axial power shaping rod motion tests and the "quick look" video camera insertion.

\subsubsection{Technical Support Activities}

During this fiscal year, the technical support activities included an examination of expected source terms during refueling, studies of criticality during recovery, evaluation of TMI-steam generator tube corrosion, studies of the elution of a cestum-loaded zeolite column that is currently a significant radioactivity source tn the containment bullding, development of a method for chloride removal from RCS water, examination of possible causes for fallure of thc self-powered neutron detectors at TMI-2, studies of the rate of uptake of cesium and strontium by specific zeol11.38, and varlous chemical analyses.

\subsubsection{Development of Inorganic Sorbents}

EIghteen candidate Inorganic sorkents were screened for possible use In the decontamination of aqueous streams likely to be encountered in light water reactor systems. This activity was terminated at the conclustion of the screening tests, however, in order to focus attention on more urgent problems associated with TMI-2 recovery. 


\section{SPENT FUELS PROGRAM}


1. SPENT FUELS PROGRAM

\author{
L. B. Shappert
}

\title{
1.1 INTRODUCTION
}

The goal of this task is to support the Domestic Spent Fuel Storage Program through studies involving the transport of spent fuel. The major objective is to develop a transportation catalog for spent fuel.

\subsection{PROGRESS}

Technical progress for the task of this program for the fiscal year just ended follows.

\subsubsection{Spent Fuel Storage (L. B. Shappert)}

A catalog was developed to provide authoritative, timely, and accessible transportation information for persons involved in the transport of irradiated reactor fuel. The catalog, drafted and submitted to the Transportation Technology Center, Sandia National Laboratories, for their review and approval, covers such topics as federal, state, and local regulations, spent fuel characteristics, cask characteristics, transportation costs, and emergency response information.

\subsection{PUBLICATIONS}

None.

\subsection{REPERENCES}

None. 


\title{
2. AIRBORNE WASTE MANAGEAENT PROGRAM
}

\author{
W. W. Pitt
}

\subsection{INTRODUCTION}

The airborne release of ${ }^{14} \mathrm{C}$ fron various nuclear facilities has been identified as a potential blo-hazard due to the long half-ilfe of ${ }^{14} \mathrm{C}(5730$ years) and the ease with which it my be assinflated into the biosphere. The objective of the ${ }^{14} \mathrm{C}$ Innobilization task is to develop technology for the removal and imobilization of this radionuclide. Prior studies have Indicated that ${ }^{14} \mathrm{C}$ will likely exist in the oxidized form as $\mathrm{CO}_{2}$ and will contribute slightly to the bulk $\mathrm{CO}_{2}$ concentration of the gas stream, which Is alrlike in nature $\left(\sim 330 \mathrm{ppm}_{\mathrm{v}} \mathrm{CO}_{2}\right)$. The technology under development utflizes the $\mathrm{CO}_{2}-\mathrm{Ba}(\mathrm{OH})_{2} \cdot 8 \mathrm{H}_{2} \mathrm{O}$ gas-solid reaction with the mode of gassolid contacting belng a fixed bed. The product, $\mathrm{BaCO}_{3}$, possesses excellent thermal and chemical stability, prerequisites for the long-term disposal of nuclear wastes. For optimal process operation, studies have Indicated that an operating window of adquate size does exist. When operating within the window, high $\mathrm{CO}_{2}$ removal efficlency (effluent concentrations $\left(100 \mathrm{ppb}_{\mathrm{v}}\right)$, high reactant utilization ( $\left.>99 \%\right)$, and an acceptable pressure drop across the bed $(3 \mathrm{kPa} / \mathrm{m}$ at a superficlal veloctty of $13 \mathrm{~cm} / \mathrm{s}$ ) are possible. The experimental program has addressed three areas of experimental investigation: (1) microscale studies on 150-mg samples to provide information concerning surface properties, kinetics, and equilibrlum vapor pressures; (2) macroscale studies on large flxed beds ( $4.2 \mathrm{~kg}$ of reactant) to determine the effects of humidity, temperature, and gas flow rate upon bed-pressure drop and $\mathrm{CO}_{2}$ breakthrough; and (3) design, 
construction, and initial operation of a pllot unit capable of continuousiy processing a $34 \mathrm{n}^{3} / \mathrm{h}\left(20-\mathrm{ft}^{3} / \mathrm{min}\right)$ air-based gas stream.

The objective of the Filter Test Facflities Qualfty Assurance task is to derrelop a set of standardized procerures for the operation and guidance of the three DOE Filter Test Facflities at Richland, Washington; Rocky Flats, Colorado; and Oak Ridge, Tennessee; to analyze operating data from the three facilities to determine trends with respect to operating loads and quality of HEPA filters being supplied to DOE contractors; and to provide general technical assistnce to the Filter Test Facilities and to the DOE Alrborne Waste Program.

\subsection{PROGRESS}

Technical progress for the Carbon-14 Immobilization task and Filter Test Faciltty Quality Assurance task for FY 1982 follows.

\subsubsection{Carbon-14 Immobilization (G. L. Haag, J. W. Nehls, Jr. and W. G. Chapman)}

Extensive studies on $\mathrm{Ba}(\mathrm{OH})_{2}$ hydrates, their reaction with $\mathrm{CO}_{2}$, and the operation of fixed-bed processes for $\mathrm{CO}_{2}$ removal from alr-based gas streams $\left(330 \mathrm{ppm}_{\mathrm{v}} \mathrm{CO}_{2}\right)$ were continued and the results analyzed. Macroscale studies have indicated that (1) the published vapor pressure for $\mathrm{Ba}(\mathrm{OH})_{2} \cdot 8 \mathrm{H}_{2} \mathrm{O}$ is valld, (2) the rate of dehydration of $\mathrm{Ba}(\mathrm{OH})_{2} \cdot 8 \mathrm{H}_{2} \mathrm{O}$ to $\mathrm{Ba}(\mathrm{OH})_{2} \cdot 3 \mathrm{H}_{2} \mathrm{O}$ and the subsequent rehydration at relative humidities $<55 \%$ 18 proportional to the amount of free water on the surface (1.e. a function of - lative humidity), and (3) the reactivity of $\mathrm{Ba}(\mathrm{OH}) 2 \cdot 8 \mathrm{H}_{2} \mathrm{O}$ for $\mathrm{CO}_{2} 183$ orders of magnitude greater than that of elther $\mathrm{Ba}(\mathrm{OH})_{2} \cdot 3 \mathrm{H}_{2} \mathrm{O}$ or $\mathrm{Ba}(\mathrm{OH})_{2} \cdot \mathrm{H}_{2} \mathrm{O}$. Macroscale studies under near-18othermal conditions on 10.2-cm-ID flxed beds of commerclal $\mathrm{Ba}(\mathrm{OH})_{2} \cdot 8 \mathrm{H}_{2} \mathrm{O}$ flakes (reference 
superficial velocity of $13 \mathrm{~cm} / \mathrm{s}$ ) Indicated that the pressure drop across the bed Increased dramatically as 557 relative humidity in the influent gas was approached. The dependancy upon relative humidity rather than water vapor pressure was confirwed by the consistancy of data obtained at two temperatures, $22^{\circ} \mathrm{C}$ and $32^{\circ} \mathrm{C}$ (a difference in the water vapor saturation pressure of $15.8 \mathrm{mom}$ ). Sinilar studies conducted with the ${ }^{14} \mathrm{C}$ Imobilization pilot unit under near-adiabatic conditions Indicated a simflar increase in pressure drop when the influent relative hunidity approached 55\%. Because of the adiabatic nature of the reaction, the terperature of the gas stream decreased by $\sim 4^{\circ} \mathrm{C}$ upon passing through the bed. It is speculated that the increase in pressure drop results from the capillary condensation of water at V-shaped contact point or pores within the solid. The presence of the condensed water incurs two phenomenom. First, the substoichiometer flakes hydrate and recrystallze upon forming $\mathrm{Ba}(\mathrm{OH})_{2} \cdot 8 \mathrm{H}_{2} \mathrm{O}$. During the step, the flakes tend to curl and although the surface area is increased, the flakes are more fragile. Second, studies have indicated that the surface area of the product decreases as the relative humidity increases. This would indicate a subsequent increase in crystallite size with decreasing relative humidity. We Ejeculate that the larger crystallites are more likely to cleave from one another and that this results in flake degradation and increased pressure drop. This information will be addressed in greater detall in a final report.

Experimental studies indicated that the transfer of the ieactant ga: through the gas film is the major resistance to mass transfer. A modei, assuming gas film control, was developed and exact numerical solutions were obtalned. An excellent correlation between the model-predicted breakthrough curves and the experimental breakthrough curve was obtained 
when the area avallable for mss transfer was modeled as a linear function of conversion [1.e. $\left.A=A_{0}(1-X)\right]$. The magnitude of the mass transfer coefficlent was rharacteristic of literature values. There were Indications that the magnitude of the initial surface area avallable for reaction, $A_{0}$, way be weak function of velocity dise to a reallignment of the flakes. This reallignment results from fluid shear forces and an accompanying reduction in the mumber of planar contact points between neighboring flakes; thus, Increasing the area avallable for mass transfer. Based upon the experimental data obtalned during this study and its subsequent analyses, a window or regime of optimal process operation under near-1sothermal and near-adiabatic conditions was determined to exist for the fixed-bed process. The window is bounded on the lower side by the dissoctation vapor pressure of $\mathrm{Ba}(\mathrm{OH})_{2} \cdot 8 \mathrm{H}_{2} \mathrm{O}$ and on the upper side by the onset of apprectable caplllary condensation and subsequent pressure drop problems ( 557 relative humidity). An operating envelope 18 presented in P1g. 2.1 for the treatment of a 330-ppmv- $\mathrm{CO}_{2}$ gas stream. The relative humidity of the influent gas must fall within the envelope for optimal gas throughput. The operating envelope also demonstrates why operational problems at 22 and $32^{\circ} \mathrm{C}$ were not severe and why considerable difficulty was encountered when trying to operate the process at $42^{\circ} \mathrm{C}$.

In the development of this fixed-bed technology, a pilot unit capable of processing $34 \mathrm{~m}^{3} / \mathrm{h}(20 \mathrm{ft} 3 / \mathrm{min})$ was designed, constructed, and operated. Specific goals of this aspect of process development were to provide (1) the basis for the design of a ${ }^{14} \mathrm{C}$ immobilization module for future testing under hot conditions; (2) data at operating conditions not achievable with present bench-scale equipment, in particular, operation at 
TEMPERATURE $\left({ }^{\circ} \mathrm{C}\right)$

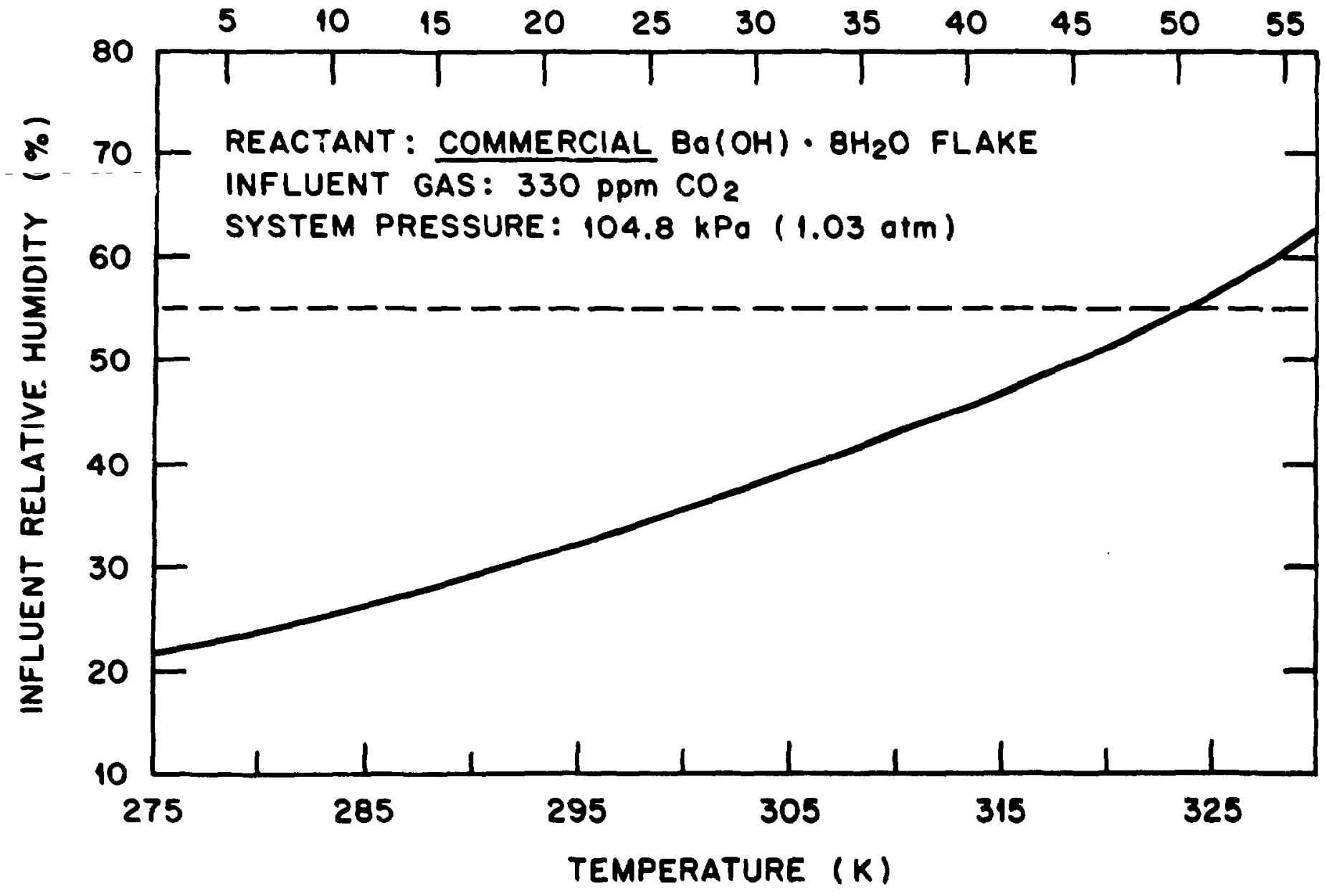

Fig. 2.1. Operating window for contacting a 330-ppmv $\mathrm{CO}_{2}$ sas stream with fixed beds of commerclal $\mathrm{Ba}(\mathrm{OH}) 2 \cdot 8 \mathrm{H}_{2} \mathrm{O}$ flakes. 
near-adabatic conditions; (3) necessary scale-up data; and (4) operating data on key hardware items and instrumentation.

A flow-instrumentation diagran of the ${ }^{14} \mathrm{C}$ Inmobilization pilot unic is shown in Fig. 2.2. A photograph of the system is presented in Fig. 2.3. The designed gas throughput at a superficial veiocity of $13 \mathrm{~cm} / \mathrm{s}$ in the reactor is $34 \mathrm{~m}^{3} / \mathrm{h}\left(20 \mathrm{ft}^{3} / \mathrm{min}\right)$. The system cinsists of two reactors which contain canisters loaded ifth $32 \mathrm{~kg}(70 \mathrm{lb})$ of comercial $\mathrm{Ba}(\mathrm{OH}) 2 \cdot 8 \mathrm{H}_{2} \mathrm{O}$ reactant. Due to the size of the canisters and the relatively long loadIng times prior to breakthrough, continuous operation with only two reactors is posible. Approximately 2100 hours of operating time (8 cell loadings) were accumulated prior to the termination of the experimental work. Detailed results of these studies will be preselted in a final report.

\subsubsection{Filter Test Facility Quality Assurance (C.A. Burchsted)}

\subsubsection{Standards}

Three meetings of the Filter Test Facilities (FTF) Standards Writing Group were held during the year, one at each station. Although earlfer plans called for a family of elght standards to provide the required guidance for FTF operations, this was reduced to four by combining several related topics into one standard, NE F 3-43. Final drafts of two standards, NE F 3-42, Operating Policy for DOE Filter Test Facilities, and NE F 3-43. DOE F1lter Test Fac1lity Operating Procedures, were completed and submitted to the Technical Review Committee for preliminary review prior to balloting. Preliminary drafts of two additional standards, one a gulde for preparing quality assurance programs for the FTFs and the second 


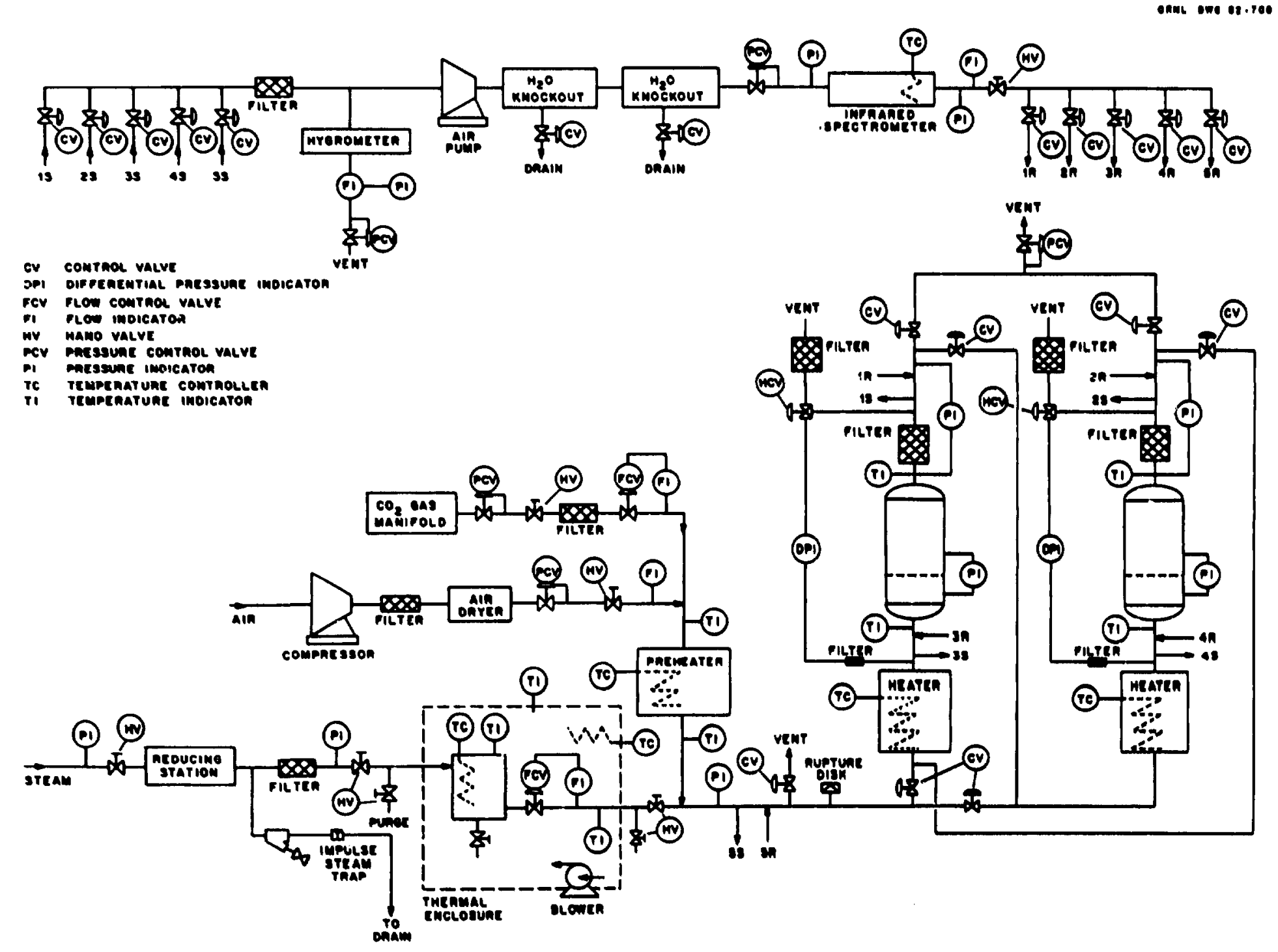

Fig. 2.2. Flow-instrumentation diagram of the ${ }^{14} \mathrm{C}$ Immobllization pilot unit. 


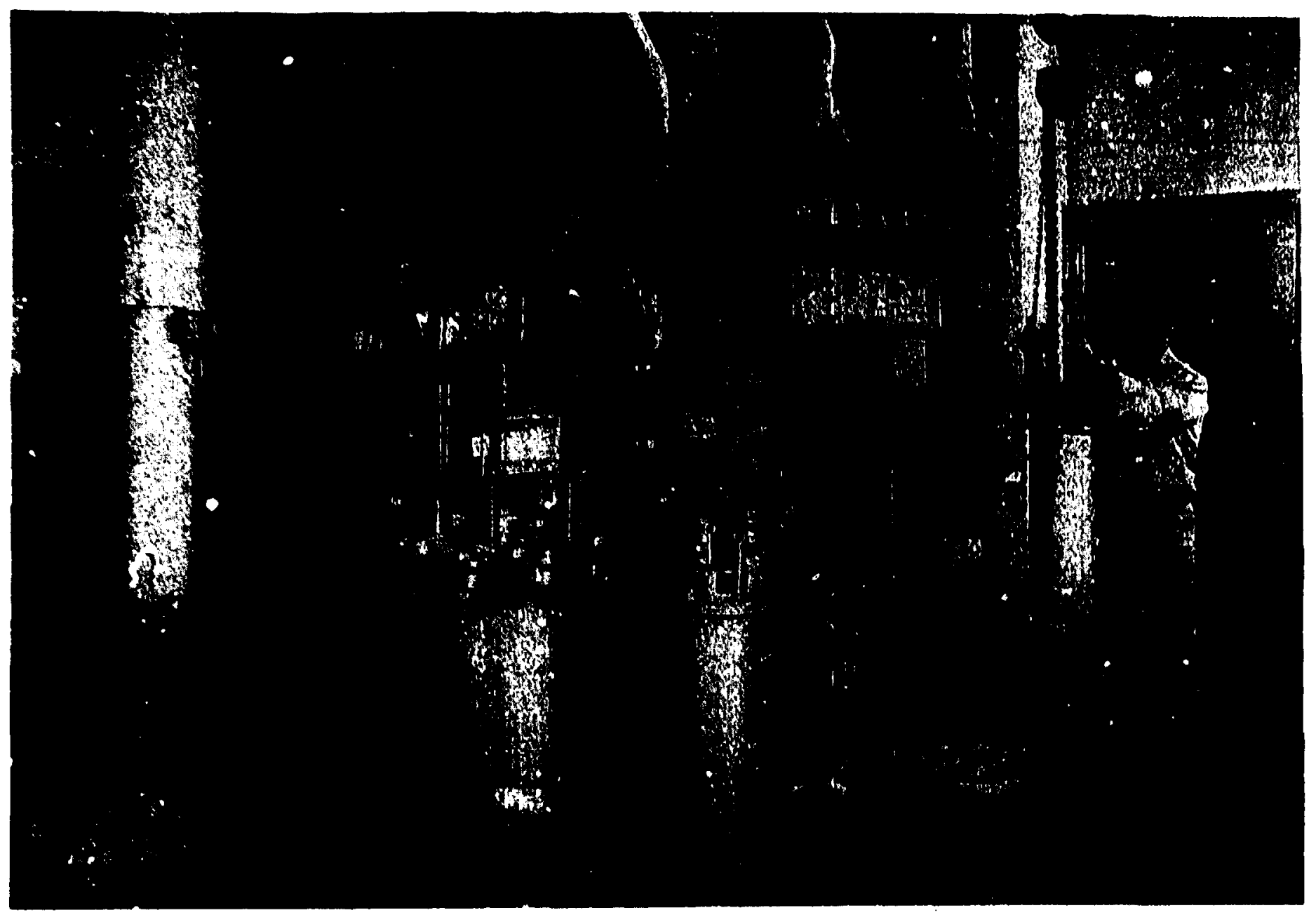

F18. 2.3. The ${ }^{14} \mathrm{C}$ immobilization p1lot unit. 
a guide for procurement of HEPA filters by DOE contractors, were started and will be presented to the Writing Group early in FY-1983.

\subsubsection{Round Robin}

Proccdures for round robin tests to validate FTF operations were completed and incorporated in NE standard F 3-43. The inftial round robin was started at the end of the fiscal year and will be complete during the first quarter of FY-1983. Round robins wil be conducted at least annually In the future.

\subsubsection{Operating Data Analysis}

A review of FTF operating data for the years 1960 (intitiation of FTF program) through 1980 was completed. Findings were reported to DOE and as a paper at the 17 th DOE Nuclear AIr Cleaning Conference. With a change of emphasis and the addition of data for 1981 , the findings were also reported at the World Filtration Congress III.

\subsection{PUBLICATIONS}

C. A. Burchsted, "Experience In the quality Assurance Testing of HEPA Filters," pp 15-22 in the Proceedings of World Filtration Congress III, Sept. 13-17, 1982.

G. L. Haag, Application of the $\mathrm{CO}_{2}-\mathrm{Ba}(\mathrm{OH})_{2} \cdot 8 \mathrm{H}_{2} \mathrm{O}$ Gas-Solid Reaction for the Treatment of Dilute $\mathrm{CO}_{2}$-Bearing Gas Streams, Ph.D. Dissertation, University of Tennessee, Knoxville; and ORNL-5887 (in preparation).

G. L. Haag, J. W. Nehls, Jr., and G. C. Young, "Carbon-14 Immobillzation via the $\mathrm{Ba}(\mathrm{OH})_{2} \cdot 8 \mathrm{H}_{2} \mathrm{O}$ Process," Proceedings of the $17 \mathrm{th}$ DOE Nuclear A1r Cleaning Conference, Denver, Co., Aug. 2-5, i982. 
C. A. Burchsted, A Review of DOE Filter Test Facflity Operations, 1970 Through 1980," Proceedings of the 17th DOE Nuclear Air Cleaning

Conference, Denver, C0., Aug. 2-5, 1982.

\subsection{REFERENCES}

No se. 


\section{BYPRODUCTS UTILIZATION MANAGEMENT PROGRAM}

S. M. Tiegs

\subsection{INTRODUCTION}

Field testing of radioluminescent lights was conducted in concert with development and fabrication. The field tests provided input from various Department of Defense services and the program was expanded to incluie infrared lights and aircraft instrument lighting. As a consequence, participation by the Army has becomr an important focal point for extended utilization, especially by the rapid deployment forces. Important improvements were made to increase light output by proper selection of phosphors, application of phosphors to the tubes and tube geometry.

A cesium-137 WESF capsule used in the Sandia sludge irradiator was examined for internal corrosion and capsule tensile strength. Solubility testing of fully-active cesium pollucite was completed.

\subsection{PROGRESS}

Techniral progress for each of the tasks of this program for fiscal year 1982 follows.

\subsubsection{Terrestrial Radioisotope Application Development (F. N. Case, K. W. Haff, J. A. Tompkins, and F. J. Schultz)}

\subsubsection{Radioluminescent Light Source Development}

3.2.1.1.1 Phosphor Development. A survey was made to obtain candidate samples cf phosphors for testing with tritium to maximize light output. Eighteen phosphor samples were obtained and tested for light output when exposed to tritium. From this group, one yellow-green and one infrared phosphor were salected for use in fabrication of light tubes. The yellowgreen phosphor increased Ifght output approximately $20 \%$ over the best phosphor used in earlier work. Phosphor particle size has been identified as an important parameter in light output; however, work has not progressed to the point of selection of an optimum size for a given phosphor. Phosphor coating thickness control and proper composition of binders for the application of phosphors to glass tubes are required to obtain 
uniform coatings of phosphors on tubes. In our earlier work with binders we used a silicune binder that provided a highly stable adhesive for phosphor coatings. However, this preparation was a proprietary product and has been discontinued. Work was then conducted using the conventional phosphoric acid binders, and satisfactory methods for coating tubes were developed. Decomposition of the phosphor when it is exposed to phosphoric acid occurs to a limited extent at the phosphor/glass interface. A formulation consisting of $0.5 \%$ phosphoric acid in a $95 \%$ acetone, $5 \%$ hexyl alcohoi mixture was found to bind the phosphor to well-cleaned and hydrofluoric acid-etched glass.

Ten phosphor manufacturers and supplie:s in the U.S., Europe, and Japan were contacted in a search for more efficient phosphors for wse with tritium and krypton-85. The search resulted in a phosphor with a $20 \%$ greater light output.

\subsection{Fabrication and Light Fixture Developmen:- Runway distance} markers were fabricated and supplied to Tyndall Air Force Base for testing and evaluation. These $4 \times 4 \mathrm{ft}$ square markers were assembled and shipped to Tyndall for installation. Each marker contained flat glass light tubes $1 / 4 \mathrm{in}$. thick $\times 3 / 4 \mathrm{in}$. wide that varied in length from 4 to $22 \mathrm{in.}$ Thirty individual units were fabricated that comprised both runway distance markers and taxiway information signs. (Figure 3.2.1)

ORNL-PHOTO $5717-80$

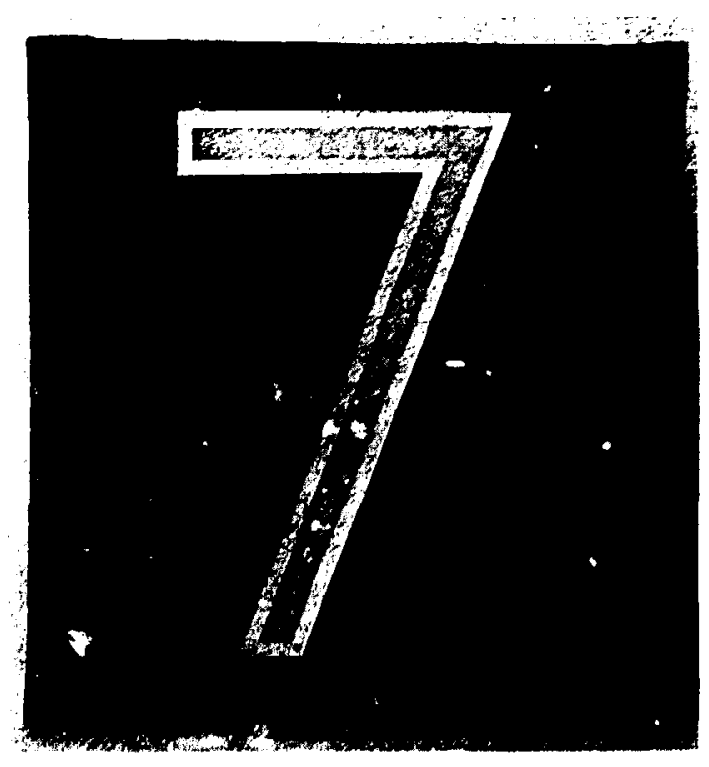

Figure 3.2.1 Typical Tritlum Taxiway Sign 
Approximately 150 runway edge lights comprised of 120 visible and 30 infrared lights were fabricated and tested. These units consisted of three individual pyrex light tubes containing $32 \mathrm{Ci}$ of tritium each and packaged inside a 1-1/2 in. diameter polycarbonate tube sealed in:it. Each unit had 10 in. of light projection over its 15 in. of total length. In use, two units are deployed on a "tee" shaped holder (Figure 3.2.2) placed in the ground at the edge of an airfield runway. This arrangement makes it easy to deploy the units and provides for 6 in. of spacing between individual lights on the holder. Thus, the apparent light size is increased, making the acquisition distance greater than is possible with Individual lights.

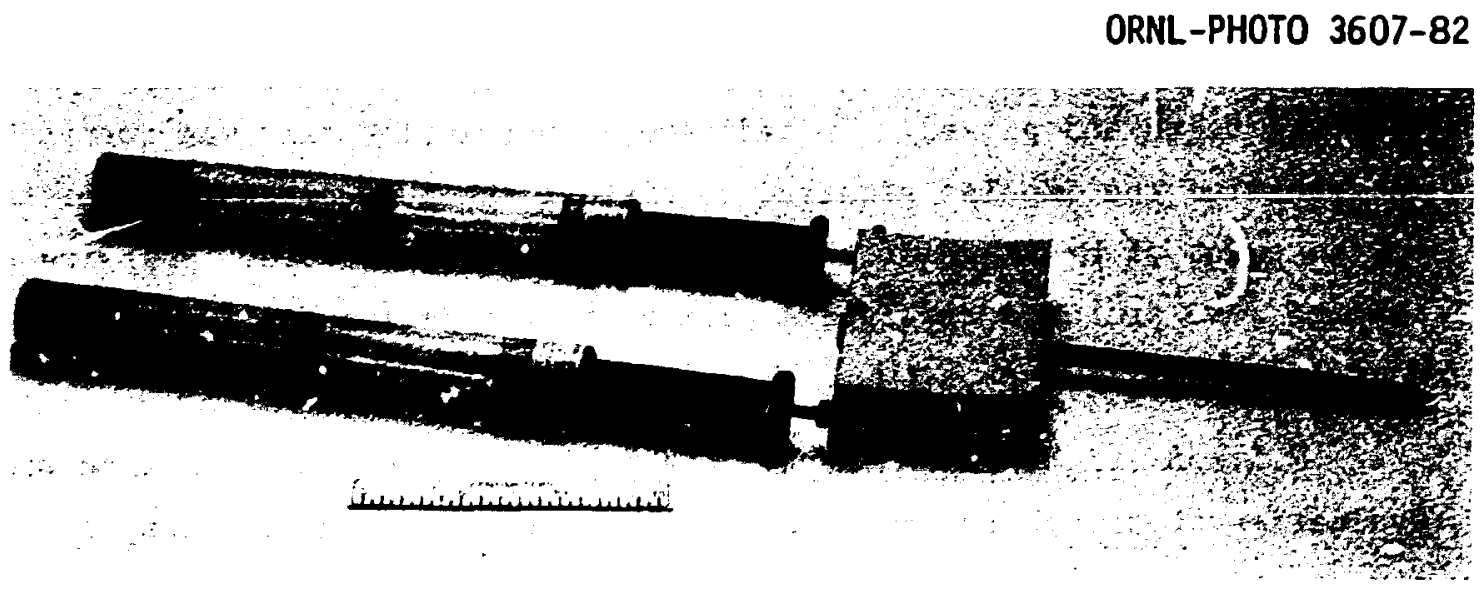

Figure 3.2.2 Tritium Lights Assembled on "Tee" Holder

A small fixture containing three 6 in. long light tubes assembled inside of a 1-1/2 in. diameter polycarbonate sealed tube and equipped with a handle and a stud bolt for attaching several fixtures end to end was designed and tested. These fixtures were developed to meet a need by rapid deployment forces for use in marking drop zones and for identification of combat-important ground locations. Both visible and infrared phosphors were used in these fixtures. Field tests are scheduled for FY 1983.

3.2.1.1.3 Ruggedizing. Military use of radioluminescent lights requires ruggedized systems to permit afr dropping, rough handing, and exposure to environmental extremes. Clear polycarbonate provides more resistance to breakage than any of the transparent construction plastics avallable and is used to enclose the pyrex glass tubes containing the phosphor and radionuclide. The tubes are shock mounted on silicone rubber foam spacers and 
resist breakage under normal handling and shipping conditions. High-speed photography was used to observe deflections in the pyrex tubes that occur during mechanical shock conditions. The photographic observatiuns are presently being evaluated. The objective of this effoit is to develop methods for testing and diagnostic examination that will permit the fabrication of fixtures that will meet military combat requirements.

3.2.1.1.4 Physical Testing. Testing of light fixtures and shipping cartons to meet ANSI and DOT standards was carried out. Two lighting systems were tested. Runway distance markers were teeted to neet the ANSI standard for self-luminous signs, and an NRC license for use of the markers at Tyndall Air Force Base was obtained. The hand-held lights, consisting of three tubes in a polycarbonate fixture, were tested according to ANSI standard tests and passed. In acidtion, a percussion test was carried out to determine the impulse required to distort the polycarbonate cover tube to the point of breakage of the internal pyrex light tubes. Shipping containers were procured and Type A package certification testing was conducted.

3.2.1.1.5 Light Measurement. Light output measurement is required for evaluation of phosphors and to optimize geometry for fabrication of light fixtures. Equipment was installed in a totally dark, non-reflective walled area. This equipment consists of an EG\&G, Model 550 Photometer. One huidred fifty candella measurements were made for krypton-85 lights fabricated and tested for runway edge lights and for taxiway lights. A typical 1socandella profile is shown in Figure 3.2.3. Infrared light output was obtained using this photometer also.

3.2.1.1.6 Field Testing. The major effort for the year involved fabrication of fixtures and field testing for military applications. This was a highly productive effort from the standpoint of introducing the military to the potential of radioluminescent lights as a reliable and longlived light source for low-level 11ghting. Suggestions from user personnel provided the direction needed to make the program functional and to expand participation of various military services.

Ft. Rucker Alabama Test. A demonstration of visible lights, with both kxypton-85 and tritium lights, was given during a General staff conference 


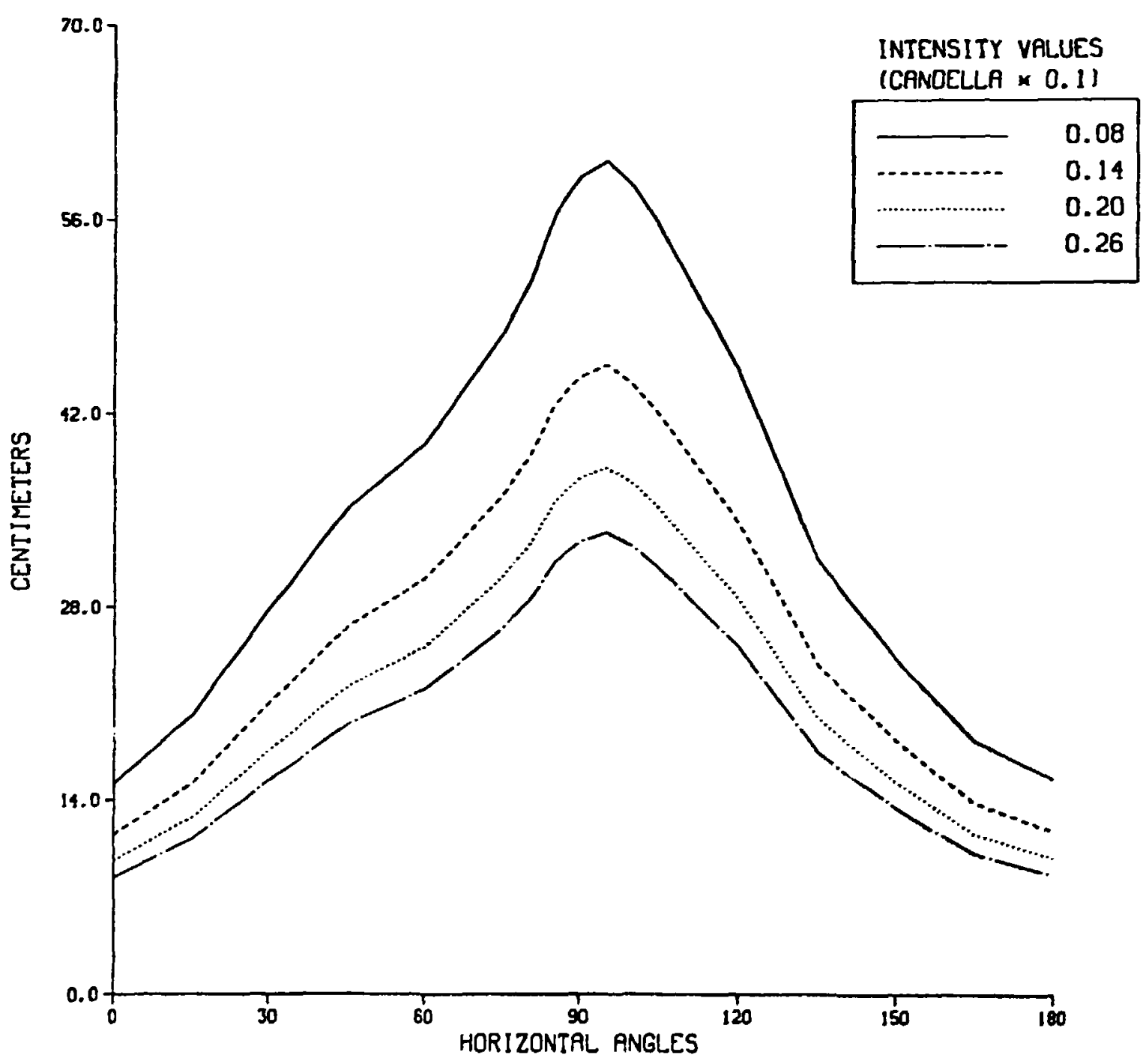

Figure 3.2.3 Isocandella Curves for a Krypton-85 Light Source with Bimdirectional Light Pipe 
at Ft. Rucker, Alabama, in March 1982. This demonstration provided several General officers with a first hand observation of the lights and their potential applications. It also permitted reviewing with night vision equipment by the conference attendees. A full test in May 1982, also at Ft. Rucker, was conducted to demonstrate helicopter landing field marking. This test used single three-tube tritium light wands set out in a line excending from each end of two parallel rumays to provide alignment for aircraft maneuvers. Lights were deployed for five nights and used in training exercises. Both visible and infrared lights were used in this test. Pilot evaluation was favorable and the lights were judged to be adequate for lane marking in remote field applications.

Pope Air Force Base, North Carolina. A field test was conducted at Pope Air Force Base, North Carolina to compare visible and infrared radioluminescent lights with battery operated units. The battery operated infrared unfts were judged to be about two times brighter than the radioluminescent lights. The radioluminescent lights, however, appeared to be adequate for most requirements and have the added advantage of reliability not possible with battery operated units. The radioluminescent lights have many potential military applications. At the field test it was suggested that paratrooper wrist altimeters be fitted with tritium lights. Two units were obtained and flluminated with tritium light sources for evaluation.

Naval Ship Yard - Connecticut. A test was conducted to determine the visibility of a standard three-tube light under conditions of murky waters as might be encountered during a ditching of a helicopter from the deck of a ship. The objective was to provide an exit light that is unaffected by electrical power failure to orient the pilot of the aircraft, in or under water. Further testing was fudged to be necessary with increased intensity of light or one of different spectral quality.

Fort Huachuca, Arizona. A planning session and a field test were conducted at Fort Huachuca, Arizona to test use of 1ights under desert conditions and in a low-ambient light environment. The test was set up at a simulated base airfield of the type used by advance combat raisid deployment forces. One hundred twenty lights were fabricated and deployed as runway edge lighting and threshold 1ighting. Helicopter and Mohawk afrcraft were used in this test. The Iighting system was reviewec by Army rapld deployment officers and enlisted personnel and was fudged to be acceptable as a 
landing aid when used with radar guidance for field location. Recomendation of a second bare base test to be made in Hawail was put in form of an Army request by the Hawaiian base commander who was visiting Ft. Huachuca. A glide slope indicator was set up using both visible and infrared lights and was used successfully by helicopters.

Marine Corps Auxiliary Landing Field, Bogue, North Carolina. A demonstration of rumay edge lighting and classified infrared tests were conducted at the MCALF, Bogue, North Carolina, along with a meeting of the program technical guidance comittee. The test involved rumway edge lighting used by helicopters. A paratroop jump zone marking and paratroop jump test originally planned for this demonstration were scrubbed due to inclement weather. This has been rescheduled for the Spring of 1983 at Ft. Benning, Georgia.

Oak Ridge National Laboratory. A test was held at ORNL using a remote site set up as an air strip (grass) for helicopter landing and combat maneuvers with the radioluminescent tritium lights and nighi vision equipment. The aircraft, a Huey helicopter, was supplied by the North Carolina National Guard. Fdge lighting and infrared glide slope markers were deployed for use in training with night vision equipment. The field will be used for prototype light testing.

3.2.1.1.7 Instrument Lighting. Work was started in FY 1982 to evaluate radioluminescent lights for cockpit instrument lighting to fulfill a need for cockpit lighting that is compatible with advanced night vision equipment. Present incandescent lighting causes the electro-optical systems of this equipment, designed to operate at very low-light levels, to fail by aperture closing when excessive light is intercepted. The radioininescent light is compatible with the advanced night vision equipment; therefore, it may be used for cockpit 1ighting. While limitations of no capability for changes in intensity or on/off warning light signals are a negative factor in instrument lighting, the reliability of light sources and ease of retrofit makes the effort attractive. An assortment of instruments that represent types used on Huey helicopters was obtained from the Afrcraft Depot at Tucson, Arizona. Illumination is obtained by reflection onto the dial face from light sources placed in the frame around the dial. Good visibility was obtained. Two of the instruments have been fitted with 
visible light sources. Maximum instrument visibility can be obtained by back lighting the instruments. However, this would require major instrument redesign in some cases; therefore, its application would be limited and retrofit expensive.

A second area of radioluminescent light development related to instrument lighting fnvolves external aircraft markers. Two helicopter rotor tip lights were prepared for placement on the ends of the rotor blade. These lights consisted of a donut shaped tube encased in polyester resin and attached to the rotor inspection plate. Extensive testing to determine structural integrity will be necessary before these lights can be deployed as an aircraft component. This work was started late in FY 1982 and will continue inte the FY 1983 effort.

A major accomplishment in the program was achieved by R. E. Nelson and W. C. Remini in arranging for flight time support by the North Carolina Air National Guard. Since this guard unit has as its objective $100 \%$ qualified night vision operator sapability, their participation is an important key in the byproduct utilization program.

\subsubsection{Examination of WESF Cesium Capsule}

A ${ }^{137} \mathrm{CsC1}$ Waste Encapsulation and Storage (WESF) capsule, No. C-117, was transferred from the Sandia Irradiator for Dried Sewage Solids to ORNL for an intensive examination of its physical properties. See Figure 3.2.4 for a detailed description of a WESF capsule. The capsule was loaded on September 25, 1975, and opened on September 11, 1981. The examination of the capsule and the resulcs obtained include the following:

(a) Composite in-cell photographs of both the inner and outer capsules vere obtained through a Köhl-Morgan periscope (see Figures 3.2.5 through 3.2.7).

(b) Skin temperature measurements of the inner and outer capsules were made using a chromel-alumel contact thermocouple. The results of the WESF capsule temperature measurements are:

$\begin{array}{cc}\text { Capsule } & \text { Skin Temperature }\left({ }^{\circ} \mathrm{F}\right) \\ \text { Outer } & 220 \\ \text { Inner } & 260\end{array}$


$0 \operatorname{anc}-0.060$ - 01340

\begin{tabular}{|c|c|c|c|c|c|}
\hline \multirow{3}{*}{ Lomons } & \multirow{3}{*}{ 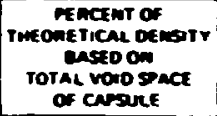 } & \multicolumn{4}{|c|}{ TE GERATUAE } \\
\hline & & \multicolumn{2}{|c|}{ an } & \multicolumn{2}{|c|}{ waten } \\
\hline & & CEMTER LINE & Sumfact & CENTEn UANE & seme ace \\
\hline$\infty \times c$ & $\infty$ & $\infty 6$ & 2000 & Dre & ste $c$ \\
\hline
\end{tabular}

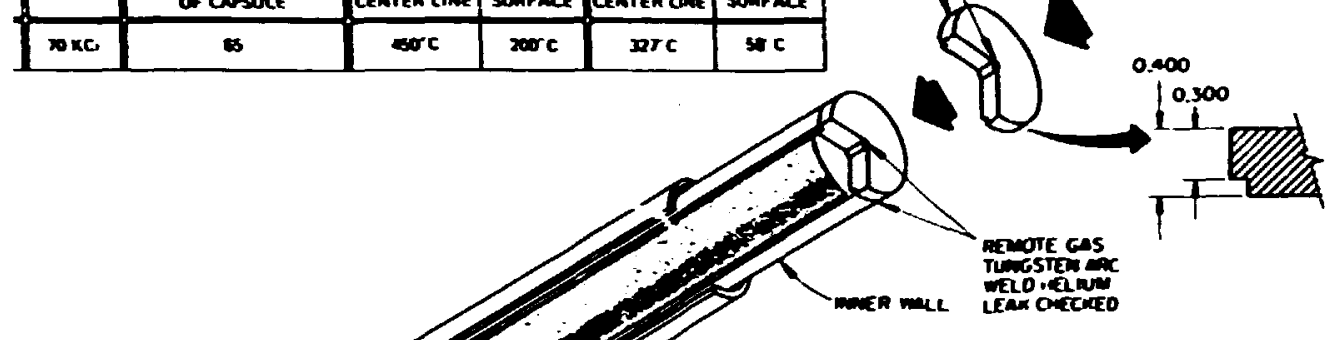

iss Tumestem ate TESTEO cutin

juTEn wet

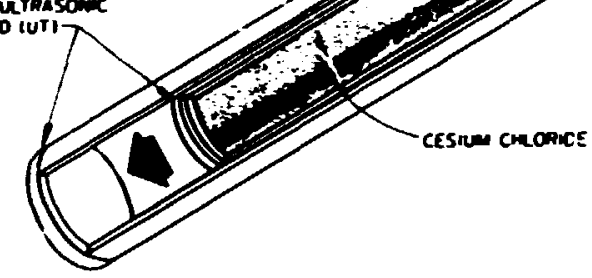

\begin{tabular}{|c|c|c|c|c|c|c|c|c|c|c|}
\hline & \multicolumn{10}{|c|}{ carsule } \\
\hline & \multicolumn{5}{|c|}{ InUEAs } & \multicolumn{5}{|c|}{ outen } \\
\hline & mitenial & $\begin{array}{c}\text { Dall } \\
\text { Thicentess }\end{array}$ & $\begin{array}{l}\text { OUTSSOE } \\
\text { OANETEA }\end{array}$ & $\begin{array}{l}\text { TOTAL } \\
\text { LENGTH }\end{array}$ & $\begin{array}{l}\text { TOTAL CAO } \\
\text { THICx Mess }\end{array}$ & matemial & $\begin{array}{c}\text { WALL } \\
\text { InICKMESS }\end{array}$ & $\begin{array}{l}\text { WUTSDE } \\
\text { OANETER }\end{array}$ & $\begin{array}{l}\text { TOTAL } \\
\text { LEMTH }\end{array}$ & $\begin{array}{l}\text { TOTal Cal } \\
\text { Twiexhess }\end{array}$ \\
\hline $\begin{array}{l}\text { CESIU: } \\
\text { CHLOAIOE }\end{array}$ & $\begin{array}{l}\text { JWL } \\
\text { ST AUNLESS } \\
\text { STEEL } \\
\text { UUTI }\end{array}$ & $\begin{array}{l}\text { o.cess } \\
\text { IUTi }\end{array}$ & 2.750 & 73 & 0 & $\begin{array}{c}\text { 3ISL } \\
\text { STANLES } \\
\text { STEE. } \\
\text { IUT. }\end{array}$ & $\begin{array}{l}0.100 \\
\text { IUTi }\end{array}$ & 2.675 & sans & 0.000 \\
\hline
\end{tabular}

Figure 3.2.4 Hanford Vaste Encapsulation and Storage Facility Capsule

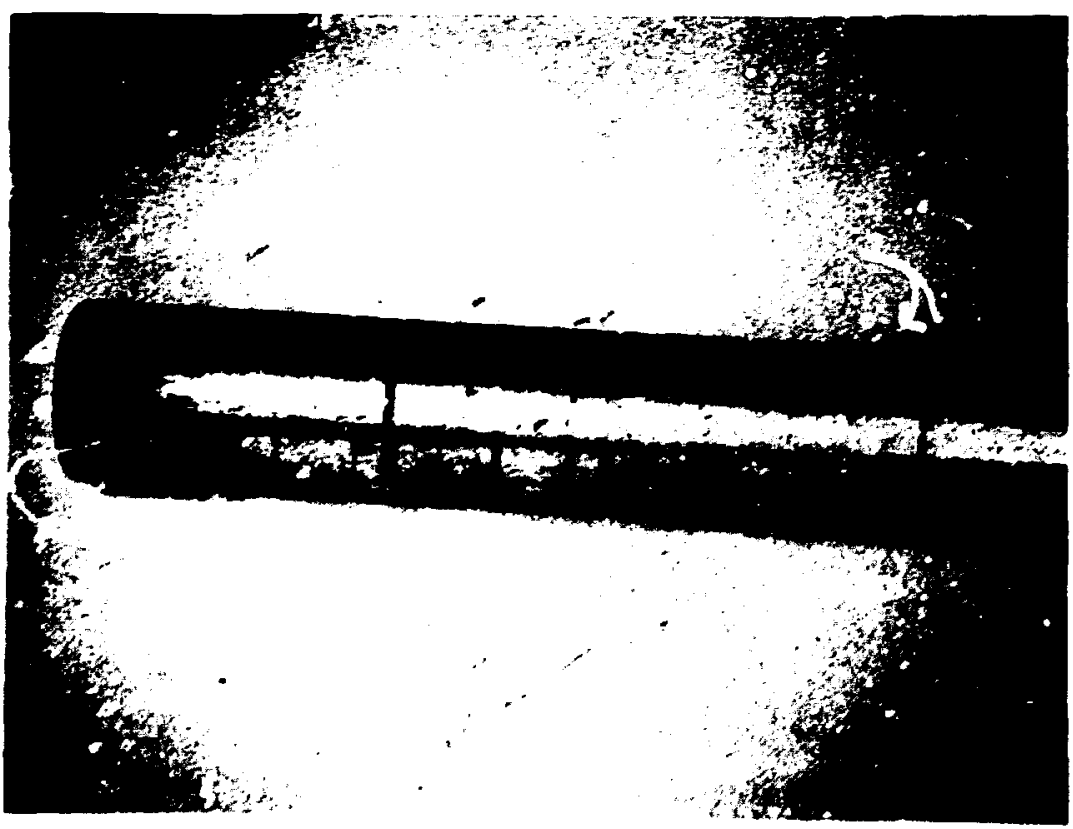

Figure 3.2.5 In-Cell View of WESF CsC1 Outer Cap3ule 




Fjgure 3.2.6 In-Cell View of WESF CsCI Inner Capsule

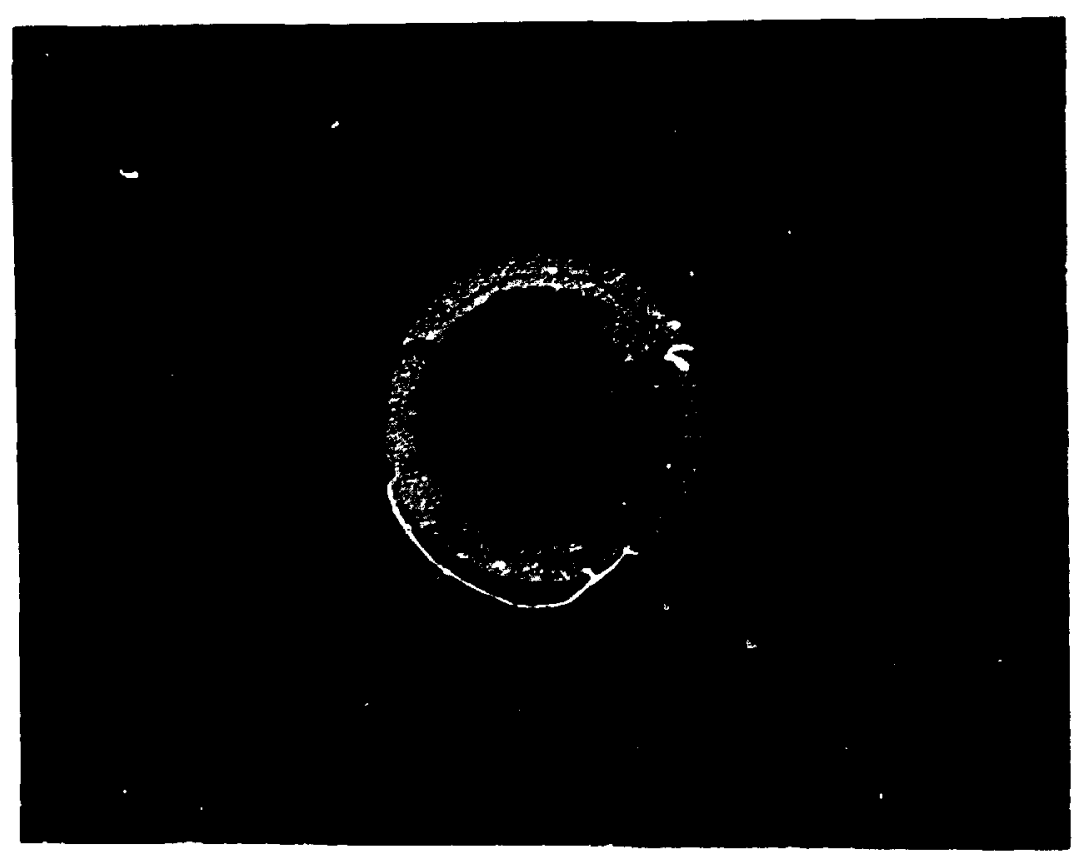

Figure 3.2.7 In-Cell View of $\mathrm{CsC1}$ Salt Contained in Inner Capsule 
(c) The gas contained in both the inner and outer capsules was quantitatively recovered by penetration of the stainless sceel walls with a laser beam and recovering the released gas in an evacuated vessel of known volume. The gas was then analyzed using a gas chromatograph/mass spectrometer ( $\mathrm{gc} / \mathrm{ms})$. The evacuated capsules were then each backfilled with He to determine the total void volume. The results of the quantitative identification of gases are presented in Table 3.2.1. The results of the void volume determination are:

\begin{tabular}{cc} 
Capsule & $\begin{array}{c}\text { Void Volume } \\
\left(\mathrm{cm}^{3}\right)\end{array}$ \\
\cline { 2 - 2 } & 244.942 \\
Outer & 134.056
\end{tabular}

Table 3.2.1. Quantitative Identification of Gases Contained in Inner and Outer Capsules

\begin{tabular}{ccc} 
Compound & $\begin{array}{c}\text { Outer Capsule } \\
\text { Gas Volume } \\
\left(\mathrm{cm}^{3} \text { at STP }\right)\end{array}$ & $\begin{array}{c}\text { Inner Capsule } \\
\text { Gas Volume } \\
\left(\mathrm{cm}^{3} \text { at STP }\right)\end{array}$ \\
\cline { 2 - 3 } $\mathrm{H}_{2}$ & 1.358 & 0.023 \\
$\mathrm{He}$ & $<0.046$ & 25.927 \\
$\mathrm{CH}_{4}$ & 0.033 & 0.006 \\
$\mathrm{H}_{2} \mathrm{O}$ & $<0.001$ & 0.067 \\
$\mathrm{~N}_{2}+\mathrm{CO}$ & 58.104 & 11.419 \\
$\mathrm{O}_{2}$ & 0.020 & 0.002 \\
$\mathrm{Ar}$ & 5.380 & 18.777 \\
$\mathrm{CO}_{2}$ & 0.722 & 0.028
\end{tabular}

(d) The mass of cesium chloride recovered from the inner capsule was $2.69 \mathrm{~kg}(5.93 \mathrm{lb})$. This represents a $2.63 \%$ loss, as the reported $\mathrm{CsC} 1$ loading was $2.76 \mathrm{~kg}(6.09 \mathrm{lb})$. Results from the cesium specific activity analysis of $\mathrm{CsCl}$ salt are:

\begin{tabular}{lc} 
Isotope & Ci/gram \\
\hline${ }^{137} \mathrm{Cs}$ & $22.1 \pm 0.3$ \\
${ }^{134} \mathrm{Cs}$ & $0.33 \pm 0.003$
\end{tabular}

The results of the cestum fsotopic ahindance analysis of the CsCl salt are: 


\author{
Isotope \\ Cesium - 133 \\ Cesium - 134 \\ Cesium - 135 \\ Cesium-137 + Barium
}

\section{Fraction}

0.57

ح10 ppm

0.10

0.33

(e) Metallographic examination of the capsule wall surfaces and weldments revealed a corrosion depth of 1 to 2 mils $(20.05 \mathrm{~mm})$ in the wall sections examined. No corrosion of the weldments was detected.

(f) Five groups of tensile specimens were machined from selected sections of the stainless steel inner and outer capsules. These included:

1. Top section of the inner capsule which contained the CsCl salt-void interface.

2. Bottom section of the inner capsule which was full of CsCl salt.

3. Section of the outer capsule.

4. Section of the new-design capsule* which was turned down to the same wall thickness as capsule $\mathrm{C}-117$.

5. Section of the new-design capsule utilizing full thickness of material.

Tensile testing of the specimens yielded smooth creep rate versus force curves indicating a ductile metal. This is the expected curve for 316L stainless steel. The specimens were cut with the tensile axis parallel to the tube axis. Specimen loading was by pins through the grips and specimen ends. The tensile tests were conducted on an Instron tensile test machine at a cross head speed of $0.05 \mathrm{in}$. per minute. All tests were conducted at room temperature $\left(24^{\circ} \mathrm{C}\right)$. The cross-sectional dimensions were measured before the test with a micrometer and post-test measurements were made using a toolmaker's microscope.

The tensile test results for the specimens removed from capsule $\mathrm{C}-117$ are presented in Table 3.2.2 and for specimens removed from the unirradiated tubing in Table 3.2.3. In addition to the strength and ductility values presented, enginecring and true fracture stresses and uniform elongation were calculated. The fracture stresses are not reported because *The new-design capsule wall thickno;s is $0.1375 \mathrm{in}$. compared to $0.97 \mathrm{n}$.
wall thickness for capsule C- 117 . 
specimen necking after fracture initiation produced errors in area measurements at fracture. All measured uniform elongations were $80 \pm 27$ of the total elongations.

Table 3.2.2 Tensile Properties of WESF CsC1 Capsule C-117 Specimens

\begin{tabular}{|c|c|c|c|c|}
\hline \multicolumn{5}{|c|}{ Strength (ksi)* } \\
\hline $\begin{array}{l}\text { Thickness } \\
\text { (in.) }\end{array}$ & $\begin{array}{c}\text { Yield } \\
0.2 \% \text { offset }\end{array}$ & Ultimate & $\begin{array}{c}\text { Elongation } \\
\text { in } 1 \text { in. } \\
(\%)\end{array}$ & $\begin{array}{l}\text { Reduction } \\
\text { of Area } \\
(\%)\end{array}$ \\
\hline
\end{tabular}

Top Inner Capsule (Above CsCl-Void Interface)

$0.097 \pm 0.00637 .6 \pm 3.079 .1 \pm 6.0 \quad 60.2 \pm 4.8 \quad 74 \pm 6$ Bottom Inner Capsule (Below CsCl-Void Interface) $0.096 \pm 0.003 \quad 47.3 \pm 4.8 \quad 82.8 \pm 4.7 \quad 49.8 \pm 5.3 \quad 75 \pm 2$

Outer Capsule

$\frac{0.112 \pm 0.00138 .3 \pm 1.0 \quad 81.3 \pm 1.961 .5 \pm 6.6 \quad 68 \pm 4}{\text { *Results reported are average values } \pm \text { standard devia- }}$

Table 3.2.3 Tensile Properties of Unirradiated Specimens

\begin{tabular}{cccc}
\multicolumn{2}{c}{ Strength (ksi)* } \\
$\begin{array}{c}\text { Thickness } \\
\text { (in.) }\end{array}$ & Yield & Ultimate & Elongation \\
in $\underset{(\%)}{1}$ in. & Reduction \\
& $0.2 \%$ offset & & $(\%)$
\end{tabular}

Group 4 (see section (f)

$0.094 \pm 0.001 \quad 44.6 \pm 4.3 \quad 95.1 \pm 4.1 \quad 54.5 \pm 5.3 \quad 66 \pm 7$

Group 5 (see section (f)

$0.144 \pm 0.001 \quad 44.4 \pm 4.6 \quad 93.4 \pm 4.0 \quad 52.0 \pm 1.4 \quad 62 \pm 5$

*Results are average values \pm 3 tandard deviation.

The longitudinal tensile properties of the type 316L stainless steel. inner and outer capsule, No. C-117, met the requirements of the ASTM Standards A-240, A-312, A-376, and A-511. Somewhat higher strength and decreased ductility were observed for the type 316L stainless steel in 
contact with the salt. One possible explanation for these differences may be the diffusion of some elemental impurities of the salt into the stainless steel resulting in an "intergranular" attack. Further examinations are $r$ =quired to confirm this hypothesis.

\subsubsection{Cesium-137 Low-Solubility Compounds}

Assaying of the fully-loaded ${ }^{137} \mathrm{Cs}$ aluminosilicate pellets leachant samples was completed. The total elapsed time the pellet specimens were leached are:

\section{Pellet Specimen}

$\begin{gathered}\text { Quasi-static, }{ }^{a} \text { sectioned, fully-loaded } \\ 137 \mathrm{Cs} \text { aluminosilicate pellets } \\ \text { S+atic, unsectioned, fully-loaded } \\ { }^{137} \mathrm{Cs} \text { aluminosilicate pellets }\end{gathered}$
$\begin{aligned} & a_{\text {Soxhlet extractor leaching. }} \\ & b \text { Immersion in distilled water. }\end{aligned}$

Total Elapsed Leaching Period (days)

245

206

The leach rates calculated from the assay results for the aluminosilfcate pellets are presented in Figures $3.2 .8,3.2 .9,3.2 .10,3.2 .11$, 3.2 .12 , and 3.2 .13 .

The results presented in Figures 3.2 .8 and 3.2 .9 for pellets $F 1$ and F2 show that the leach rates have remained essentially constant, within experimental error, after the first week of leaching. This indicates that steady-state has been achieved and the leaching of the cesium ion out of the pollucite crystal lattice is diffusion controlled (see reference 1 ).

Examination of the pellet leach rates for the quast-static leaching reveals that each pellet achieved a steady-state equilibrium with respect to cesfum ion leachability through the pollucite crystal lattice structure. Pellets 79CsP-4, 79CsP-12, and 79CsP-7 achieved approximately equal leach rrtes (see Figures $3.2 .10,3.2 .11$, and 3.2.13). However, the leach rate attained by pellet $79 \mathrm{CsP}-11$ was an order of magnitude lower than hose attained by the remaining three test pellets.

A review of the pellet fabrication history provides information which seems to explain the anomaly. The pellets were fabricated under similar 


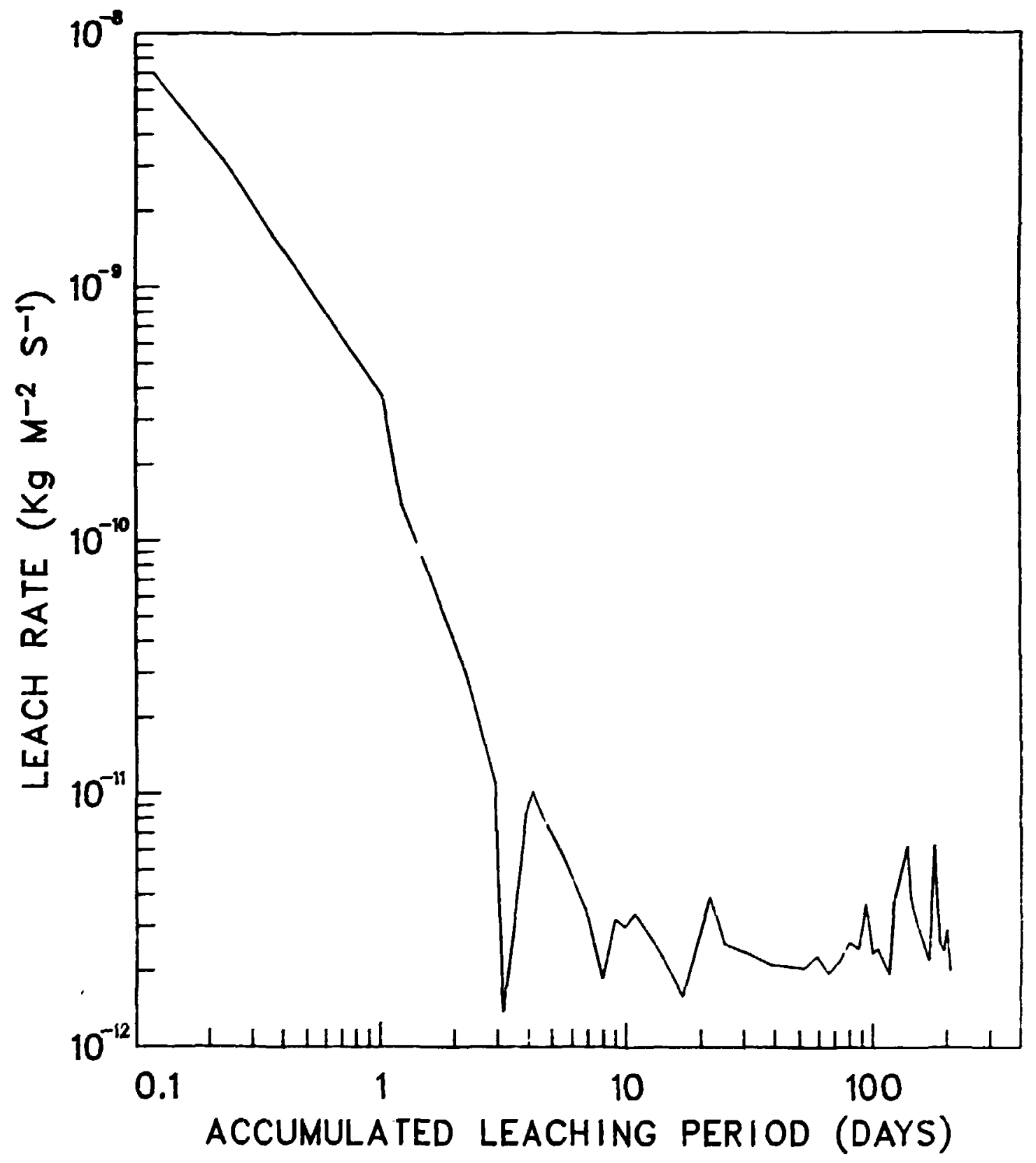

Figure 3.2.8 Aluminosilicate Pellet Fl Cesium Ion Leach Rate vs Tíme 


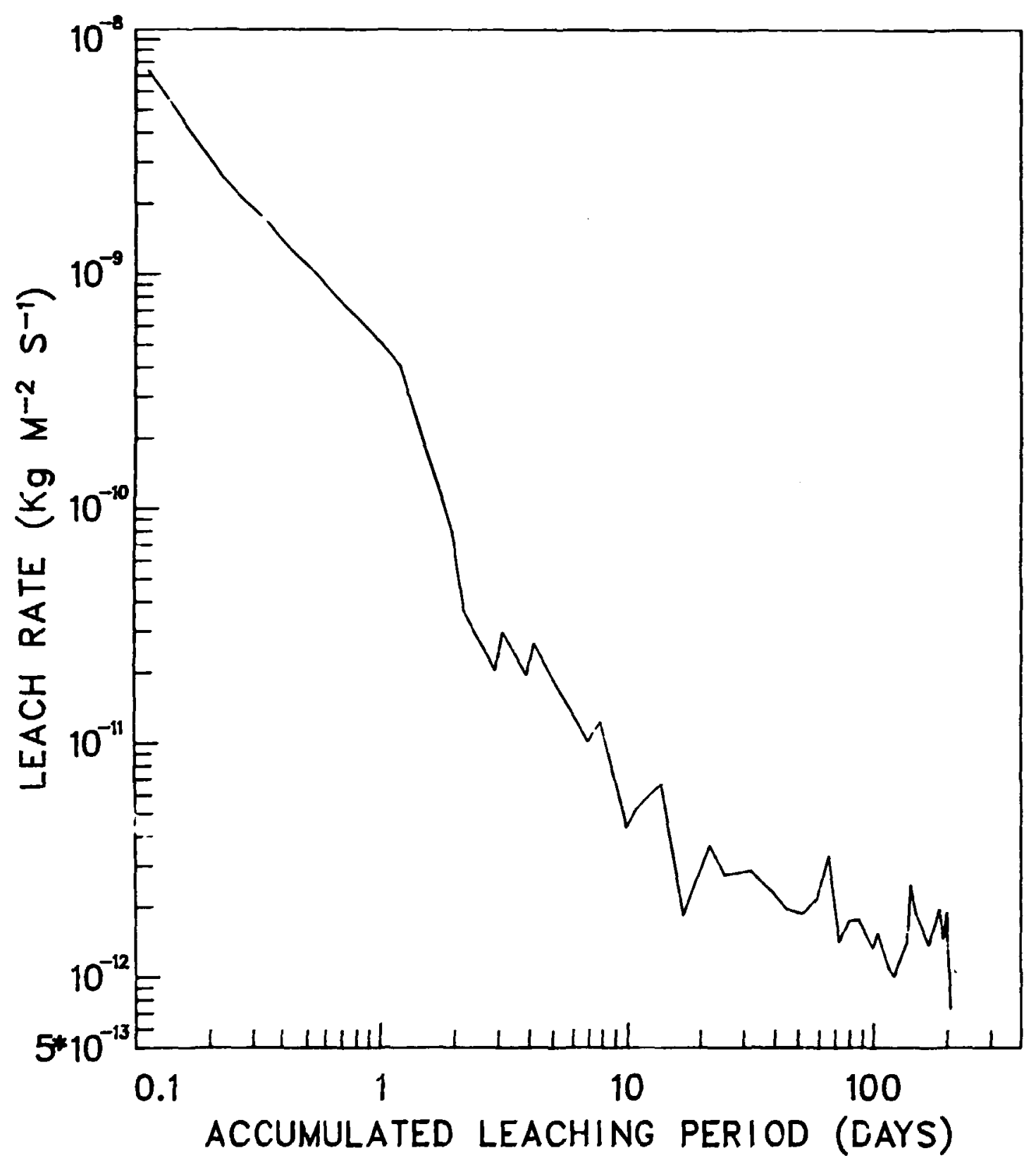

Figure 3.2.9 Aluminosilicate Pellet F2 Cesium Ion Leach Rate vs Time 


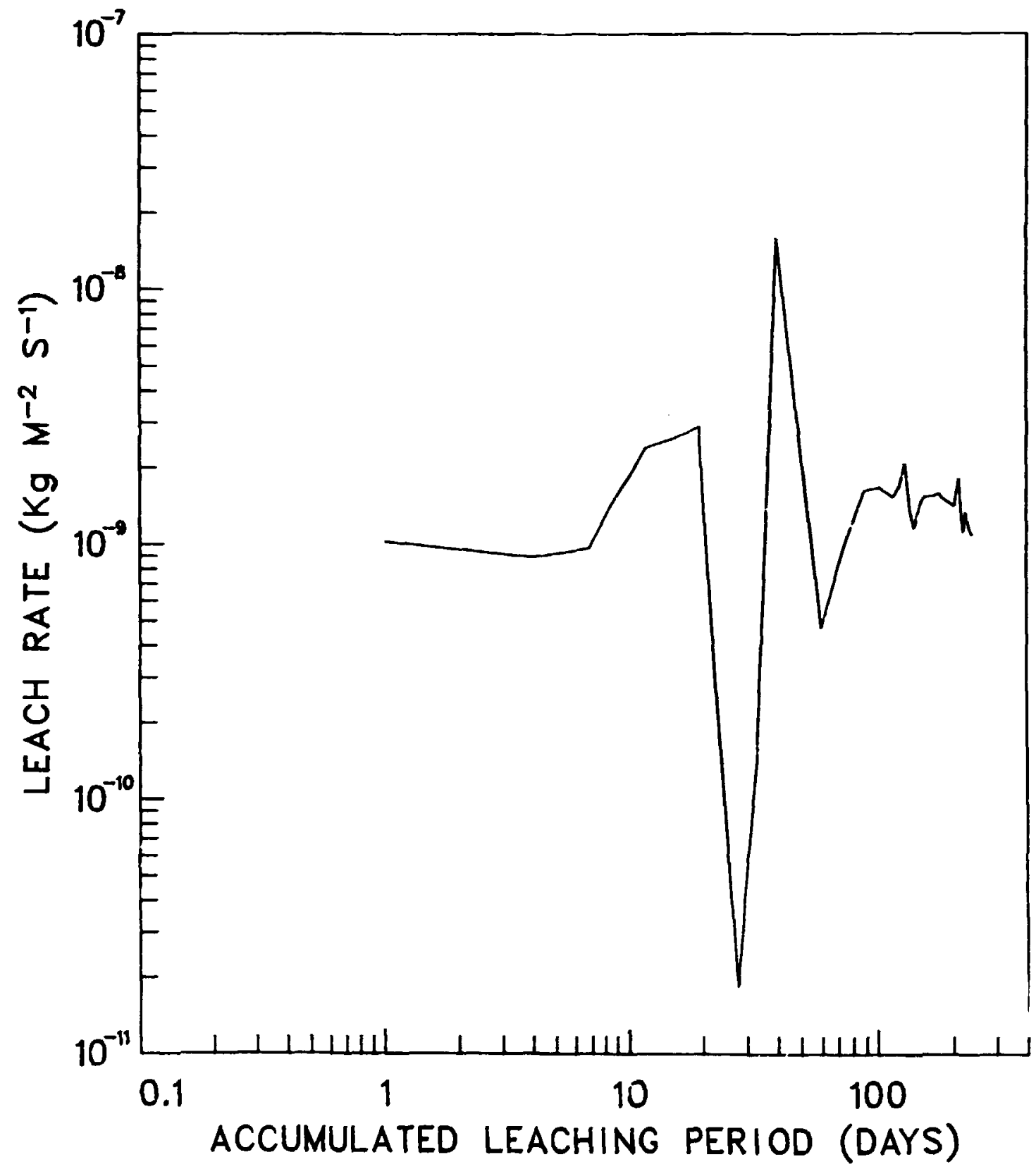

Figure 3.2.10 Aluminosilicate Pellet 79CsP-4 Soxhlet Cesiun: Ion Leach Rate vo Time 


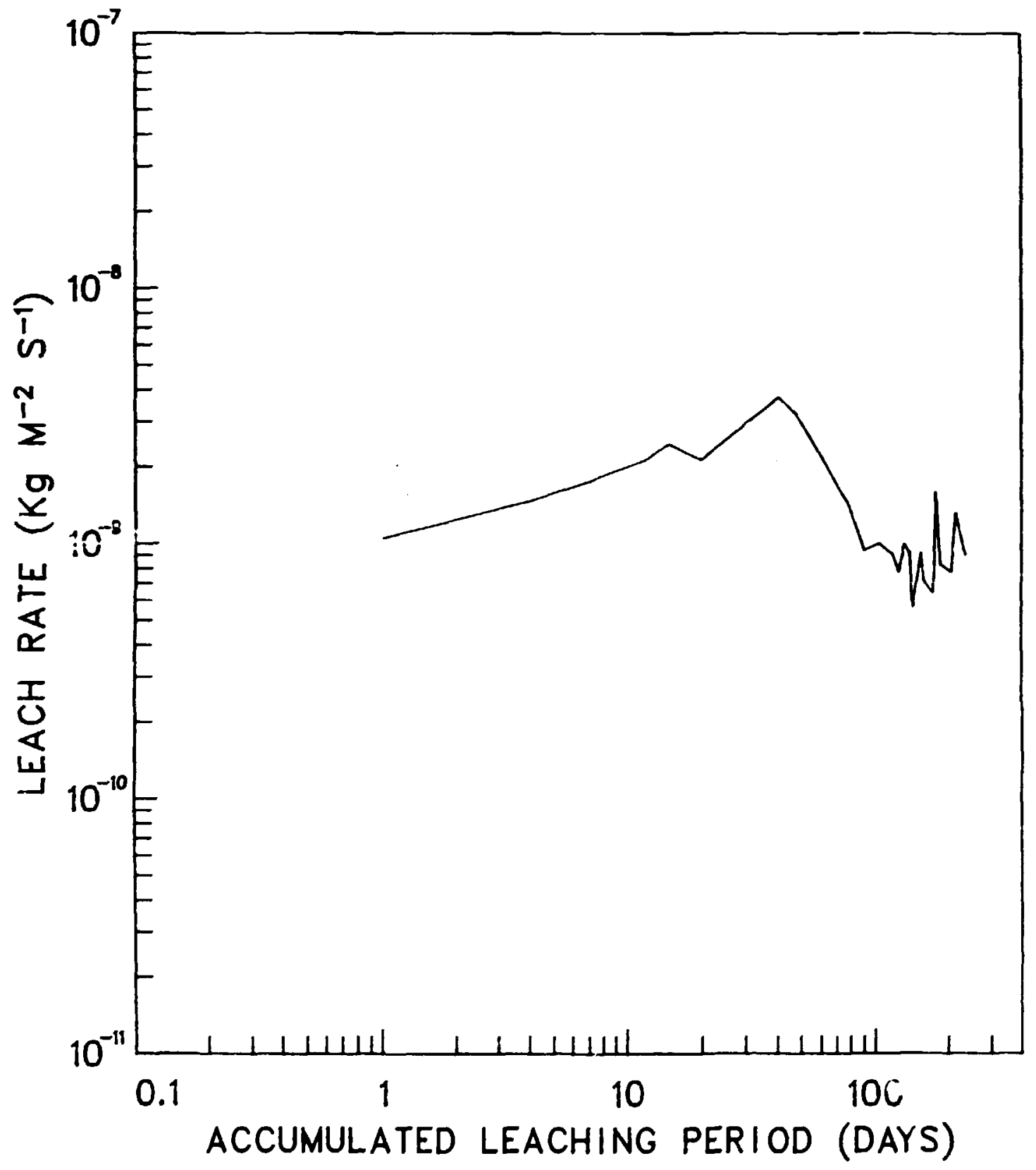

Figure 3.2.11 Aluminosilicate Pellet $79 \mathrm{CsP}-12$ Soxhlet Cesium Ion Leach Rate vs Time 


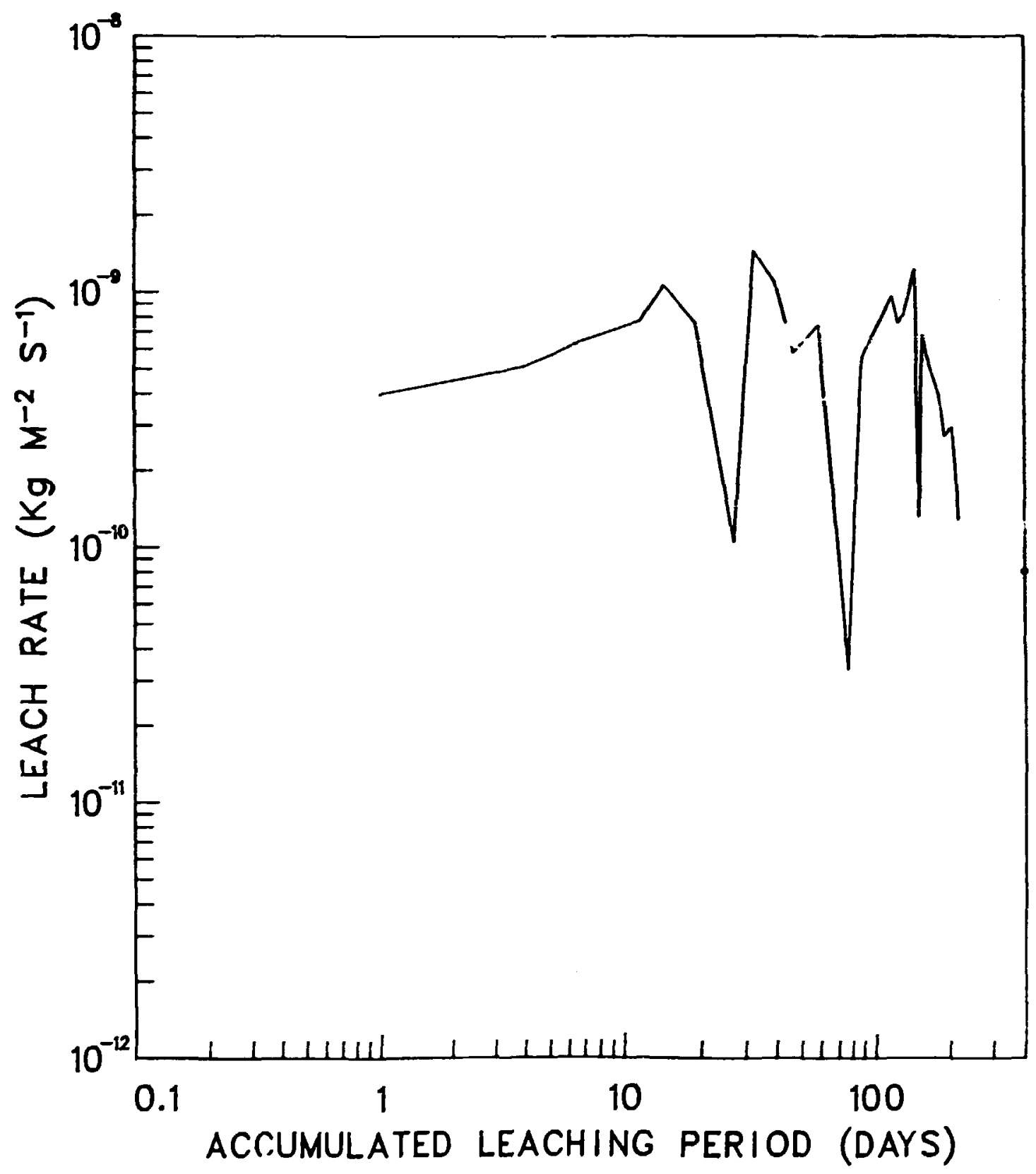

Figure 3.2.12 Aluminosilicate Pellet 79CsP-11 Soxhlet Cesium Ion Leach Rate vs Time 


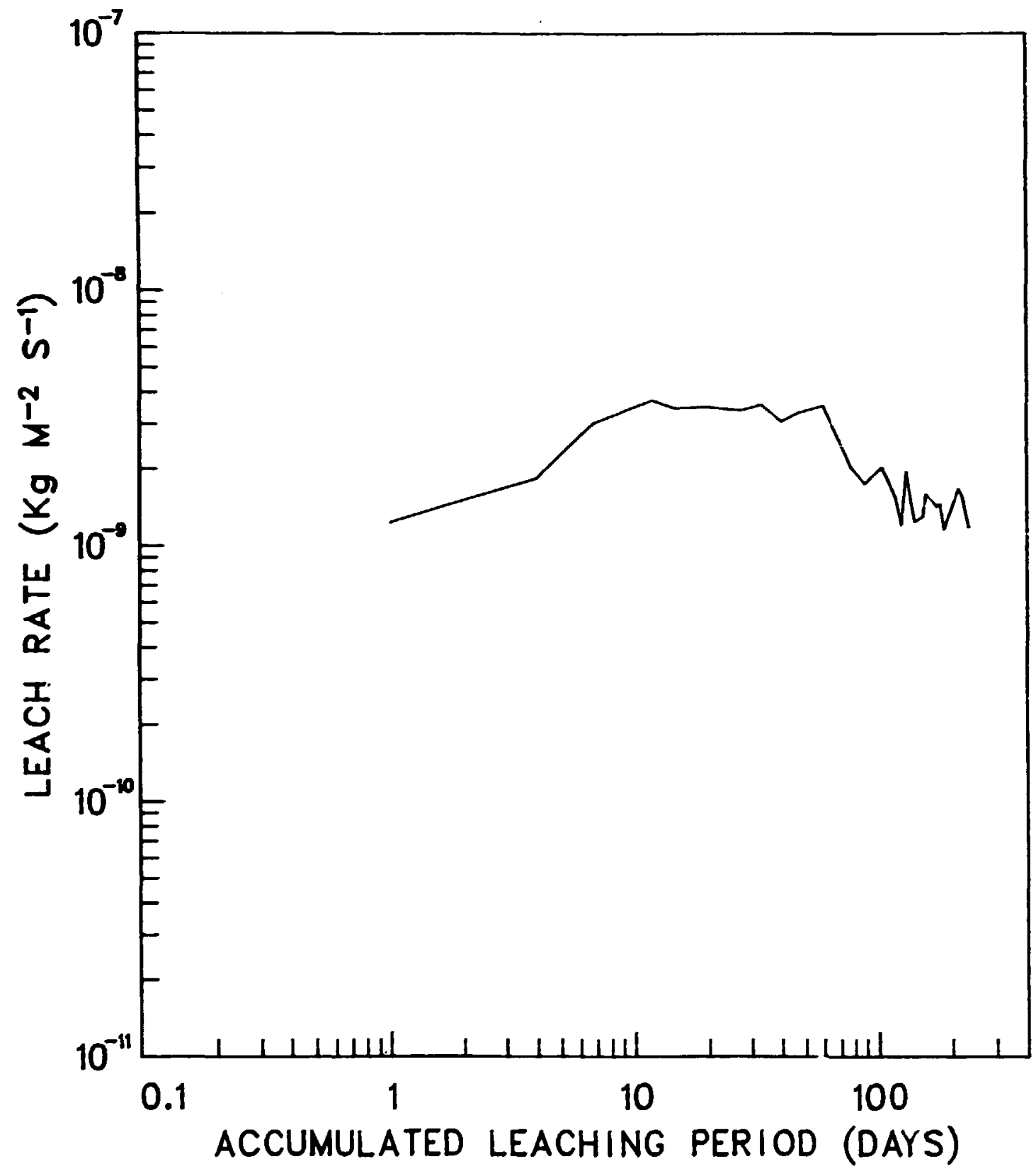

Figure 3.2.13 Aluminosilicate Pellet 79CsP-7 Soxhlet Cesium Inn Leach Rate vs Time 
DEFENSE WASTE MANAGEMENT PROGRAMS 
conditions of temperature and pressure except for one variable, curing time duration. The curing time (f.e., the length of tine the power is applied to the pellet after ram trave? has ceased) for pellet 79CsP-11 was 90 minutes as compared to 20,45 , and 10 minutes, respectively for the remaining pellets. This indicates a minimum time, $t$ (where $45<t \leq 90$ ) is required in which to assure that all of the cesium is incorporated into the pollucite crystal lattice. Otherwise, the cesium can be leached from the pellet at a rate approximately $10 \mathrm{X}$ greater (see reference 1 ).

\subsection{PUBLICATIONS}

F. J. Schultz, J. A. Tompkins, K. W. Haff, F. N. Case, Preparations and Characterizations of Cesium-137 Aluminosilicate Pellets for Radioactive Source Applications, ORNL-5775 (July 1981).

F. N. Case, K. W. Haff, J. A. Tompkins, F. J. Schultz, W. C. Remini, Radioactive Powered Light Sources, ESL-TR-82-12 (in publication); Engineering and Services Laboratory, Air Force Engineering and Services Center, Tyndall Air Force Base, Florida.

F. N. Case and K. W. Haff, Krypton-85 Powered Lights for Airfield Applications, ESL-TR-80-55 (November 1981); Engineering and Services Laboratory, Air Force Engineering and Services Center, Tyndall Air Force Base, Florida.

\subsection{REFERENCES}

1. F. J. Schultz, J. A. Tompkins, K. W. Haff, F. N. Case, Preparation and Characterization of Cesium-137 Aluminosilicate Pellets for

Radioactive Source Applications, ORNL-5775 (July 1981).

2. K. W. Haff, F. N. Case, F. J. Schultz, J. A. Tompkins, Testing of Tritfum-Poweied Runway Distance and Taxiway Markers, ESL-TR-81-45

(August 1981); Engineering and Services Laboratory, Air Force Engineering and Services Center, Tyndali Air Force Base, Florida. 


\section{SURPLUS PACILITIES MAMAGEMTNT PROGRAY}

J. H. Coobs

\subsection{INTRODUCTION}

This is the first of two prograns that are concerned with the anagement of surplus facilities. The facilities in this progran are those related to defense activities, which Include the ORNL Graphite Reactor, about 20 waste collection and storage tanks that have been retired from service, abandoned waste transfer lines, the Fission Product Development Laboratory (PPDL), and a nuber of other process and waste facllities. The progran is an Integral part of the Surplus Facilitles Managenent Program, which is a national program administered for DOE by the Richland Operations office. Objectives of the progran are tc provide for survelllance and maintenance of surplus radloactively contaminated DOE facilfties awalting decomissioning In order to assure safe conditions and to Implement a structured decommissioning program to accomplish disposition of all surplus DOE-owned facilities. The decommissioning operations are supported by financlal estimating, planning and scheduling, engineering, and technology development activtties.

\subsection{PROGRESS}

Technical progress for each of the tasks of this program for flscal year 1982 follows. 
4.2.1 Defense Surplus Facilities Surveillance and Maintenance

(R. W. Schaich, R. V. McCord, J. F. Alexander, and F. J. Peretz)

This task includes survey and inspection of surplus facilities on a regular besis, collection and analysis of samples from waste streans, replacement of exhaust afr filters on a regular basis, and maintenance of facilities as indicated by procedures and results of inspections.

Routine monitoring of containment and replacement of exhaust filters was performed at a:l facilities. Monitoring of waste systems and storage cells and malntenance of manipulators was carried out at FPDL. The demineralizer system was regenerated at the Graphite Reactor and the exhaust stack was cleaned and inspected. The storage canal at the Metal Recovery Pacility was monitored and analyzed to detect Increases in contaminants, and badly deteriorated roof hatches were repalred. A consolidated report on all phases of the radiological characterization of the Metal Recovery Facility was completed and issued, and a companion report giving details of the analysis and evaluation of subsurface soll cores near the facility was completed. Development of special equipment and procedures for survey and sampling of abandoned waste tanks was begun.

\subsubsection{Curium Facility Decomissioning (R. W. Schaich and F. J. Peretz)}

The Curium Source Fabrication Facility (CSFF) was designed and constructed in the i.rly 1960 s to prepare and encapsulate multigram quantities of curfum-242 and curfum-244 for the U.S. Atoric Energy Commission's Systems for Nuclear Auxiliary Propulsion (SNAP) program. At the termination of the SNAP program, the facility operated as a curlum-244 fuel development faclitty unt11 1979. The facllity, shown in 
Fig. 4.1, contalns four manipulator operated cells surrounded by waterfilled tanks for neutron shielding and a concrete- and steel-shielded cell that was used for final source encapsulation. Decontamination of the facility was begun in January 1981.

At the time decontamination was begun, the selected mode for decommissioning the facility was dismantlement of the water-shielded cells - and decontamination and removal of excess equipment from the other cells and the cell access area. This complete decomissioning program was estimated to cost about $\$ 2.7$ million and would have made the vacated facility avallable for further modification and reuse. On the other hand, early in FY 1982, a more imwediate use for the facility became evident recause of the Impending transfer to ORNL in FY 1983 of the uranfum-234 recovery program. This program would occupy the Alpha Handling Faclltty in Bldg. 3038, which 18 presently utilized for amerfclum operations. The proposal was made and preliminary approval obtained for transfer of the americlum-24l program to the Curium Facility, contingent upon completion of the decontamination work at the Curium Facility.

Decontamination efforts during FY 1981 concentrated on highpressure spraying with aqueous detergent solution to remove insoluble particles of $244 \mathrm{Cm}_{2} \mathrm{O}_{3}$ from cell surfaces. This method removed much contamination but was not effective in reducing alpha smear levels much below $1 \times 10^{6} \mathrm{dpm} / 100 \mathrm{~cm}^{2}$.

The next stage in the decontamination cycle was accomplished early In FY 1982 by apply1ng a Turco-4501 solution to all in-cell surface 


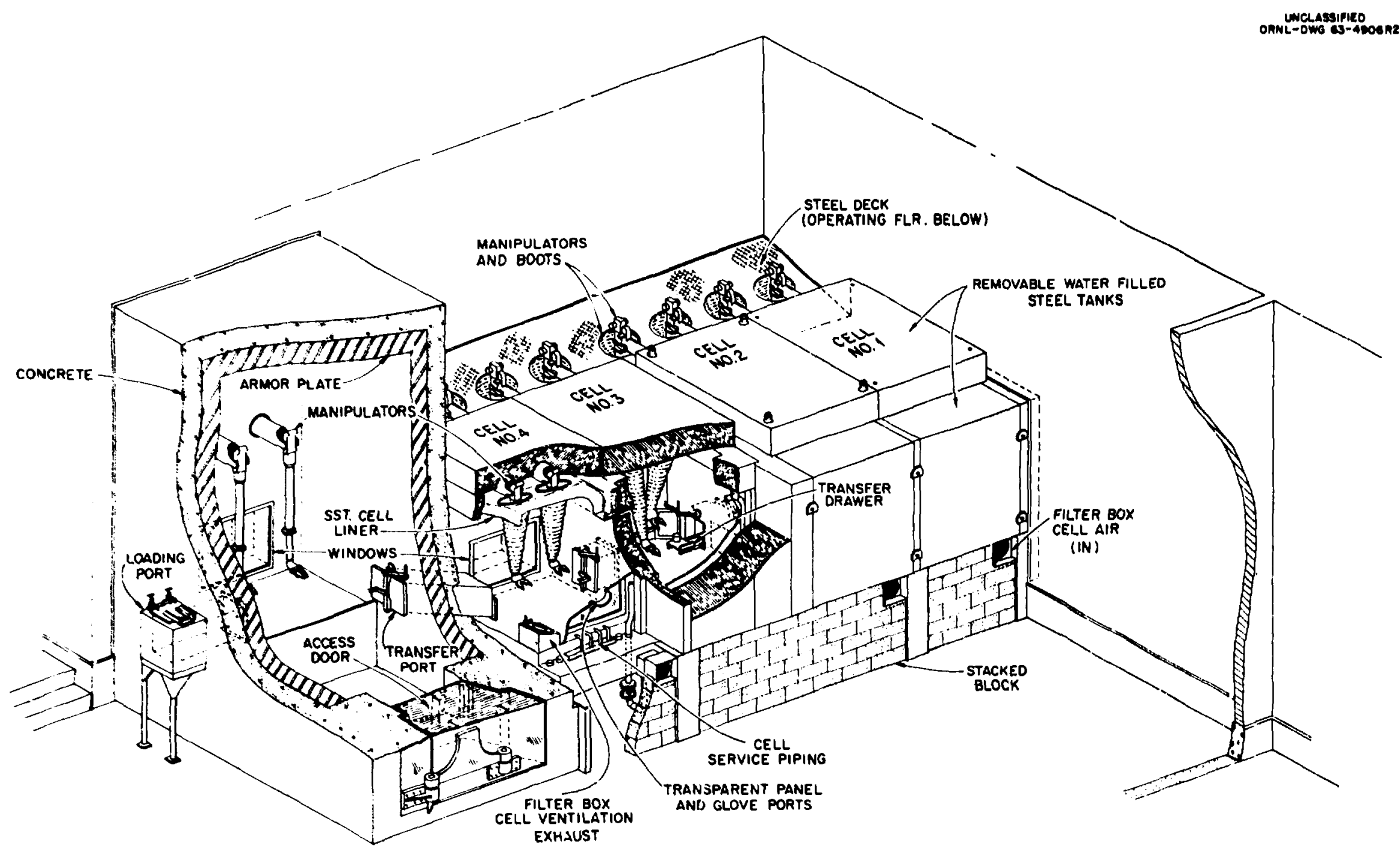

F1g. 4.1. Curlum Source Fabrication Facility. 
areas, followed by a warm oxalic acid solution rinse to remove ofl, grease, and rust that had accumulated on the non-stainless steel equipment. Following the solution decontamination cycle, all in-cell surface a reas were wiped with wet cotton swabs containing a high percentage of solid sodium bisulfate (Sani-Flush cleanser). Test wipes were removed from the cell system and were found to be alpha contaminated to greater than $1.0 \mathrm{MBq}\left(>6 \times 10^{7} \mathrm{dpm}\right)$. This decontamination procedure was repeated until the analytical data Indicated a general contamination level of less than $2.0 \mathrm{KBq}\left(<1 \times 10^{5} \mathrm{dpm}\right)$ alpha per wipe. The use of swabs was then discontinued and all accessible surface areas Inside Cell 3 were covered with a strippable paint (ALARA Decon Yellow). A plastic tent with an afrlock entry was constructed around the Cell 3 access plate, and operating personnel protected with plastic airline suits removed the cell access plate under controlled conditions. All vessels, piping, and associated equipment were coated with strippable pafnt, transferred to Cell 3, and placed In stainless steel drums for storage as TRU waste.

Pinal decontamination of the In-cell surfaces of the water shielded cells was accomplished by the wet wipes saturated with cleanser, which reduced the in-cell surface area contaminat ton to less than $1.0 \mathrm{KBq}$ $\left(<6 \times 10^{4} \mathrm{dpm}\right)$ alpha per wipe. A final application of strippable paint to the in-cell surfaces will reduce the contamination level to an acceptable tolerance for in-cell maintenance and repairs that are planned for FY 1983.

The Beta/Gamma Manipulator Cel1 (Ce11 5) was contaminated with particles contalning alpha- and beta-emitting radionuclides ( $<2 \mathrm{KBq}$ per wipe) 
due to a variety of processes that were performed in this cell over the past 20 years. The decontamination techniques used un Cell 5 were identical to those previously reported. After the contamination level had been reduced to less than $1 \mathrm{KBq}\left(<6 \times 10^{4} \mathrm{dpm}\right)$ alpha or beta on a smear, operating personnel entered the cell in plastic alrline suits, removed excess equipment, and scrubbed the in-cell surface areas by hand. An aqueous detergent solution and cleanser-pads were used until the smear level was reduced to less than $100 \mathrm{~Bq}(<6000 \mathrm{dpm})$ alpha per wipe. The surface was then painter with an epoxy paint (Colma Sol) anc the srrar level was reduced to ORN requirements $(1.0 \mathrm{~Bq}$ or $60 \mathrm{dpm}$ alpha) for the future operations planned for this cell.

Decontamination of the outer surfaces of the water shielding tanks and the cell access areas is in progress and will be completed early in FY 1983. The extended-reach manipulators that were removed from the cells were decontaminated to acceptable levels, repaired, and stored for future program use. This decontamination project will be completed at an estimated total cost of $-\$ 700,000$ and will make available for alternate use a facility that would cost several million dollars to replace.

\subsubsection{ILW Transfer Line Decommissioning (A. A. Walls, W. G. Tatum, and} The scope of this task involves removal of approximately $210 \mathrm{~m}$ (700 ft) of the abandoned 2-ln. ILW pipeline from the White Dak Creek floodplain, removal of the transfer line from the Old Hydrofracture Factlity to the New Hydrofracture Facility, and entombment of two sections of the ILW line where leaks occurred plus seallng to divert surface water and prevent erosion. 
The transfer line from the Old Hydrofracture Facllity to the New Hydrofracture Facility was removed in December 1981. This 800-ft segment of heavy-wall pipe had been used only for a test injection at the new facility and was not heavily contaminated. Sections of this pipeline were disconnected and recovered during removal and have been stored for future use.

The schedule for removal of the ILW transfer line from the floodplain was advanced to the fourth quarter of FY 1982 to avoid interference with construction activities scheduled for September and October 1982 on the new weir and channel for Monitoring Station No. 3. Excavation was begun in July, and the two parallel lines were exposed, disconnected, and dralned. The stalnless steel line was lifted, starting at the end near the old hydrofracture facility, cut into 9-ft sections, and packaged for disposal as low-level waste. Two 20-ft sectlons of the original cast iron pipe that were still connected to the stainless steel line at the east were also removed and cut into 30-in. sections for packaging Into drums and storage as TRU waste. Th1s was necessary because analyses of samples of the cast iron and mild steel plpe showed that it had adsorbed sufficlent quantities of transuranic nuclides to be classified as TRU waste whereas the stainless steel pipe was much less contaminated and could be disposed of as lowlevel waste.

The abandoned carbon steel line which paralleled the stainless line was lifted in 20-ft sections and then cut into 30-in. lengths for disposal as TRU waste. Both of the carbon steel pipe and stainless steel pipe sections which crossed White Oak Creek and extended west were 
lifted as Individual long sections from the creek bed and relocated for sectioning. Three 50-gal drums were used to store the $300 \mathrm{ft}$ of carbon steel pipe. All of the stainless steel pipe removed was packaged into 9-ft sections and disposed of as low-level waste. The operations during excavation and removal of the pipelines are shown in Fig. 4.2.

Radiation readings on the pipe were consistent with previous surveys, 1.e., $<30 \mathrm{mr} / \mathrm{h}$ on the exterfor of the pipe and $10-12 \mathrm{R} / \mathrm{h}$ on the interior of the pipe. Some holes were found in the carbon steel ire as a result of corrosion, as expected. This was especially the case for the portion of the line that was exhumed from the creek bed.

The packaged sections of pipe were removed to storage or disposal, and the excavations were closed to complete this portion of the project.

\subsection{PUBLICATIONS}

F. J. Peretz and J. F. Alexander, Results of the Radiological

Characterization of Bullding 3505, UCND Report X-OE-190 (September 1982).

\subsection{REFERENCES}

None. 


\section{HIGH-LEVEL WASTE MANAGEMENT PROGRAM}

W. W. Pitt

\subsection{INTRODUCTION}

The Defense High-Level Waste Management Program for FY 1982 consisted of only one task, "Concrete Grout Bulk Immobilization Study." The objective of this task was to provide an option for the management of existing waste at the Hanford site by:

(a) the development of tailored cement-based waste forms for Hanford wastes,

(b) evaluation of product performance and performance criteria, and

(c) providing assistance to Hanford on the selection and development of transport and emplacement technologies.

ORNL has a long history of successful laboratory and engineering development of cement-based grouts used as hosts for the immobilization of radioactive wastes. Examples of radioactive wastes fixed in tailored cement based hosts include: ion-exchange media, evaporation bottoms, filter media, waste sludges, waste slag, incinerator ash, waste calcines, shredded metal, and heavy waste oils. Through the use of additives and the application of advanced processing technology, the performance of cement based waste forms have been tailored for site specific cases. In addition, over 2 million gallons of intermediate level waste solutions and sludges have been successfully disposed of via an engineering scale grout facility, providing over 15 years of operating experience. 


\subsection{PROGRESS}

Technical progress for the three subtasks for FY 1982 follows.

\subsubsection{Concrete Grout Bulk Immobilization Study (E. W. McDaniel, L. R. Dole, G. A. West, and R. L. Hickey)}

During FY 1982 the following tasks were addressed: (1) grout mix

development of simulated Hanford wastes, (2) leach studies on simulated Redox waste, and (3) a preliminary study of leaching performance criteria.

\subsubsection{Grout Mix Development of Simulated Hanford Wastes}

Simulated supernate and sludge wastes were supplied by Rockwell Hanford for groui studies. The wastes included: (1) simulated Redox wastes, (2) three simulated Purex wastes, including non-processed, neutralized current acid waste (NPN-CAW), washed sludge and digested sludge, and (3) Zirflex/cladding wastes including $\mathrm{Mg}(\mathrm{OH})_{2}$ supernate and sludge and $\mathrm{NaOH}$ supernate and sludge.

Grout formulation studies were made for each type of waste. The initial formulations were based on those used at ORNL to dispose of waste solutions and sludges by the hydrofiacture process. These basic formulatinns were modified to accommodate the particular waste stream chemistries and to optimize waste loading, leachability and physical propertias of the resulting grout. Generally grouts were made by mixing wastes and water with a dry solids blend of cement, fly ash and clays (Indian Red and/or Attapulgite-150) in a ratio of one liter (waste/ water) per $0.8 \mathrm{Kg}$ of dry solids. Admixt.r:es ( $\leq 1$ wt $\%$ ) were added when needed as set regulators or waste reducers. The resulting waste-loaded grouts typica!ly contain $10-16$ wt \% cement, $<16$ wt. \% fly ash, and 
$<10$ wt $Z$ clays with the remainder being wastes and water. Raw materials available locally in the Pacific Northwest region were used whenever possible for the grout mixes. These included Type I-II LA cement from the Oregon Port land Cement Company, Durkee, Oregon, and Pacific Northwest pozzolan ASTM Class F fly ash from a Centralia, Washington power plant. Reference grouts were also made from standard ORNL material: including Portland Type I cement, Kingston TVA fly ash, and Ottawa graded sand.

Since the leach performance and physical properties are very sensitive to the maturity of the paste (i.e., curing time), these data must necessarily lag behind the selection of acceptable formulas. Therefore, the selection of mix formulas was based on the grouts' flow properties, which establish the formulas' compatability with standard processing technology, such as mixing, pumping, and emplacement equipment. The standard technolory has evolved from oil field grouting through the development and 20 years operation of the ORNL hydrofracture in situ solidification process. Pertinent flow properties include fluid consistency index, flow behavior index, density, critical velocity, pumping rate for critical velocity, fractional pressure drop and hydrolic horse power.

5.2.1.1.1. Grouts Prepared with Simulated Redox Waste. Formulation studies for the fixation of simulated Redox waste in a cement-based grout showed that pumpable grouts could be mede with locally available materials. Two water reducing agents, Plastiment ${ }^{\bullet}$ from sika Chemical Corp. and REAX-LP of Westvaco, Inc., where used in these tests. Rheology of the grouts made from locally available materials and standard ORNL materials indicate that raw materials have a major effect on 
grout rheology and that Plastiment ${ }^{\bullet}$ is an effective admixture in the formulas using Northwestern materials.

5.2.1.1.2. Grouts Prepared with Simulated Purex Waste. Formulation studies for the fixation of simulated Purex waste in cement-based grouts and the resulting grouts' flow propertios, were investigated for three types of waste: (1) non-processed, neutralized current acid waste (NPN-CAW) solution, (2) simulated Purex sludge that had been washed and centrifuged, (3) simulated Purex sludge that had been digested at $92^{\circ} \mathrm{C}$ for $72 \mathrm{~h}$, then washed and centrifuged.

Grouts were made with NPN-CAW waste using local Northwestern and the standard ORNL cements and fly-ashes. Three admixtures, Plastiment ${ }^{\bullet}$, D-65 $5^{\circ}$ from Dowell, Inc., and CFR-1 ${ }^{\bullet}$ from Halliburton Services, Inc., were used for each cement mixture. These grouts were plastic and fluid. Their rheological data demonstratec that these grouts' flow properties are also very sensitive to the presence of admixtures. Grouts were also prepared with NPN-CAW waste chat had been digested at $92^{\circ} \mathrm{C}$ for $72 \mathrm{~h}$, using Attapulgite-150 drilling clay as a suspender. This grout was also fluid, plastic and suitable for deep geologic disposal.

Grouts were prepared with two types of simulated Purex sludge: washed and centrifuged, and (2) digested at $92^{\circ} \mathrm{C}$ for $72 \mathrm{~h}$, washed and centrifuged. The grouts made with the digested sludge had a lower viscosity, lower pressure drop, and higher density than the undigested sludge. However, the grout with digested sludge exhibited a much higher 120 min. gel strength, wich could create problems, such as, fouling of pipelines and pumps. However, such problems are avoided by proper formulation design and equipment selection (i.e., the pump has the capacity 
to break maximum gel strength and the formulation is designed to be $\leq$ this maximum!.

Based on these results and ORNL's experience with grouting, the following conclusions can be drawn about Purex wastes:

1. Grouts prepared with non-processed, neutralized current acid waste solutions and an ORNL hydrofracture grout dry solids blend behave like hydrofracture grouts.

2. Grouts prepared with simulated Purex sludge and a dry solids blend, used at ORNL to prepare sludge-slurry grouts, behave like ORWL sludge-slurry grouts.

3. Admixtures are very effective in controlling grout flow properties.

4. Grouts prepared with digested and nondigested sludges, both washed and centrifuged, are different in character.

\subsection{Ziflex Wastes/Cladding Removal Wastes (GRW). Zirflex} decladding waste results from dissolution of the Zircaloy-2 cladding from N-reactor fuels in a boiling ammonium fluoride - amonum nitrate solution. This solution is neutralized by addition of $\mathrm{NaOH}$ resulting in a slurry consisting primarily of $2 \mathrm{rO}_{2} \cdot \mathrm{XH}_{2} \mathrm{O}$ sludge and a supernatant containing NaF. An alternative method is being evaluated tt Rockwell Hanford Operations (RHO), where the decladding waste is neutralized by addition of magnesium hydroxide rather than $\mathrm{NaOH}$. The resulting neutralized waste would consist of a mixture of $\mathrm{ZrO}_{2} \cdot \mathrm{XH}_{2} \mathrm{O}, \mathrm{MgF}_{2}$, and $\mathrm{Mg}(\mathrm{OH})_{2}$. This supernate should be nearly free of soluble ions. 
A major area of concern of fixing simulated zirflex waste in a cement based matrix is the effect of fluorides on set-time of cement, since NaF is a commonly used set retarder. Using $\mathrm{Mg}(\mathrm{OH})_{2}$ instead of NaOH to neutralize the $\mathrm{Zr}$-clading leachate (strike) eliminates this problem. The $\mathrm{Mg}(\mathrm{OH})_{2}$ precipitates soluble fluoride ions; thus reducing or eliminating the fluoride.

Thus, disposal of four types of waste were investigated:

(I) supernate of $\mathrm{Mg}(\mathrm{OH})_{2}$ strike of $\mathrm{Zr}$-cladding leachate,

(2) solids produced as a result of $\mathrm{Mg}(\mathrm{OH})_{2}$ strike of $\mathrm{Zr}$-cladding leachate,

(3) supernate of $\mathrm{NaOH}$ strike of $\mathrm{Zr}$-cladding leachate, and

(4) solids produced as a result of $\mathrm{NaOH}$ strike of $\mathrm{Zr}$-cladding leachate. Scoping tests made by mixing each simulated waste with the same dry solids blend showed that hydrofracture compatible grouts can be prepared with both $\mathrm{Mg}(\mathrm{OH})_{2}$ strike supernate and solids. The supernate prodiced a high phase separation (i.e., $\mathrm{H}_{2} \mathrm{O}$ collecting on top of grout), when mixed with a dry solids blend. The phase separation can be reduced or eliminated by increasing the dry solids.

The qualitative set (hardening) data are as follows:

1. The grout made with supernate of $\mathrm{Mg}(\mathrm{OH})_{2}$ strike was rigid to the point that the gel could not be broken after $72 \mathrm{~h}$. This is $24 \mathrm{~h}$ longer than a normal hydrofracture grout with the same mix ratio of waste to dry-solids and retarded with CRF-1 set regulator. This grout had a strong odor of ammonia.

2. The grout made with $\mathrm{NaOH}$ strike supernate showed no setting after $72 \mathrm{~h}$. 
3. The grout made with $\mathrm{H}_{\mathrm{g}}(\mathrm{OH})_{2}$ strike solids started into initial set after $72 \mathrm{~h}$, but this set could be broken. This grout had a strong ammonia odor, also.

4. The grout made with $\mathrm{NaOH}$ strike solids showed no setting at the end of $72 \mathrm{~h}$.

Based on these scoping tests, the following conclusions can be drawn:

1. A grout suitable for a variety of disposal options can be prepared with $\mathrm{Mg}(\mathrm{OH})_{2}$ strike supernate.

2. Grout prepared with NaOH strike supernate exhibits a longer set-time than is desirable. Additional development work will be required to shorten the set-time.

3. Grout can be made that contains $\mathrm{Mg}(\mathrm{OH})_{2}$ strike solids, but additional development work will be required.

4. Grout made with $\mathrm{NaOH}$ strike solids is similar to that made from $\mathrm{NaOH}$ strike supernate.

\subsubsection{Leach Studies on Simulated RHO Redox Waste}

Preliminary results are presented for static leach tests performed according to MCC-1 specifications on a grout formula designated RHO-4 using a basalt-bentonite leachant. Composition of RHO-4 is listed below:

\section{Material}

Portland Type I Cement

Kingston Fly Ash

Octawa Graded Sand

Indian Red Clay

Sludge (dry wt)

D $65^{\circ}$ Water Reducer

Water
Composition (wt z)

26.45

5.75

3.07

3.07

17.95

0.59

43.13 
The leachant was prepared by contacting deionized water with a Basalt-Bentonite mixture. The Basalt was obtained from the Rockwell Hanford Operations Energy Systems Group. The Bentonite was a bereficiated Wyoming Sodium Bentonite (trade name Thixo-gel \$2).

The leach tests were performed at $40^{\circ} \mathrm{C}$ with leachate samples taken at 3, 7, 14 and 28 days. In general, the data was consistent and showed no unexpected results. In any static leach test (such as Mcc-1), the leachate will become saturated with time. In this experiment the leachate pH, conductivity, and concentrations of aluminum, sodium, and potassium were constant after 3-7 days. The leachate had not quite been saturated with calcium in 28 days, although the solution appeared to be rapidly approaching it. Significantly, the parabolic relationship observed between the calcium leachate concentration and leach time is a strong indication that the calcium release is tue to diffusion of $\mathrm{Ca}(\mathrm{OH})_{2}$, and it does not indicate matrix dissolution.

Three methods of determining release rates for selected elements were compared. Release rates were calculated as follows:

$$
\begin{aligned}
\mathrm{NL}_{i} & =\frac{M_{i}}{\mathrm{f}_{i} \cdot S A \cdot i} \\
\mathrm{~L}_{i} & =\frac{M_{i}}{S A \cdot t} \\
\mathrm{~F}_{i} & =\frac{M_{i}}{G_{i} \cdot t} \cdot 100 \%
\end{aligned}
$$

where

$$
\begin{aligned}
& N L_{i}=\text { Normalized leach rate of component } i\left[g / \mathrm{m}^{2} \cdot \text { day }\right] \\
& M_{i}=\text { Mass of element } i \text { in leachate }[g], \\
& f_{i}=\text { Mass fraction of element } i \text { in solid sample, }
\end{aligned}
$$




$$
\begin{aligned}
& S A=\text { Solid sample surface area }\left[\mathrm{m}^{2}\right] \\
& t \quad=\text { Leach time }[\text { days }], \\
& L \quad=\text { Leach rate of components }\left[\mathrm{g} / \mathrm{m}^{2} \cdot \text { day }\right], \\
& F_{i}=\text { Fractional release rate of component } i[z / \text { day }] \text {, and } \\
& G_{i}=\text { Total mass of component } i \text { in solid sample }[g] .
\end{aligned}
$$

In general, the calculated release rates showed no surprises. As expected with a static leach test, the average release rates decreased with each time. The $z^{*}$ ali and alkaline eart. elements showed a markedly higher release rate than the heavier matrix elements. For example, $70 \%$ of the sodium was released in a 3 day period. It should be noted that these specimens were not allowed sufficient curing time to develop their potential physical properties. This resulted in higher release rates, than would be expected of mature specimens that have been cur ?d 90-128 days. Subsequent leach studies will be performed usin; mature specin:ens.

\subsubsection{Preliminary Study of Leaching Performance Criteria}

5.2.1.3.1 Background. In order to estimate the potential performance required of a grout waste host at the Hanford site, two scenarios were selected: (1) solidification in single-walled tanks, and (2) bulk solidification in the basalt repository. Assuming the $10^{-5}$ annual fractional release limit of the proposed NRC 10 CFR 60 , the necessary leaching properties were back calculated with the second conservative assumption that takes no credit for the tank-and-liner and tubbing-andbackfill for cases 1 and 2 , respectively. 
5.2.1.3.2 Methods and Results. Figures 5.1 and 5.2 were calculated, using the Joy-Godbee model:

$$
\begin{aligned}
F \cdot V / S A= & (R \cdot D)^{1 / 2}\left[(t+1 / 2 R) \operatorname{erf}(R \cdot t)^{1 / 2+}\right. \\
& \left.(t / \pi R)^{1 / 2} \exp (-R \cdot t)+1\right]
\end{aligned}
$$

where

$$
\begin{aligned}
\mathbf{F} & =\text { cumulative fraction leached at time }[t], \\
\mathbf{V} & =\text { volume of sample }\left[\mathrm{cm}^{3}\right], \\
\mathbf{S A} & =\text { surface area of samp] }\left[\mathrm{cm}^{2}\right] \\
\mathbf{R} & =\mathrm{U}^{2} / 4 \mathrm{D}, \text { moring bcundary constant }\left[\mathrm{s}^{-1}\right], \\
\mathbf{D} & =\text { apparent diffusion coefficient }\left[\mathrm{cm}^{2} / \mathrm{s}\right], \\
t & =\text { time }[\mathrm{s}], \\
U & =\text { moving boundary velocity or degradation rate }[\mathrm{cm} / \mathrm{s}], \text { and } \\
\text { erf } u & =\text { error function }=2 / \pi 1 / 2 \int u \mathrm{e}^{-z^{2}} \mathrm{dz} .
\end{aligned}
$$

This model has been shown to effectively scale the surface (SA) to volume (V) effects from small (15 $\left.\mathrm{cm}^{3}\right)$ to large (100 L) samples. Therefore, these results indicate that a smaller $\mathrm{SA} / \mathrm{V}$ ratio of large monoliths allows the use of grouts with a higher leach rate and still meet the intent of 10 CFR 60 .

Figure 5.1 shows the effective diffusion constant $\left(D_{e}\right)$ and the apparent boundary velocity $R$ required for a concrete monolith in the shape of a Hanford AX tank. For grouts with $D_{e}<10^{-13} \mathrm{~cm}^{2} / \mathrm{s}$ and $R<10^{-10} \mathrm{~s}^{-1}$, the unprotected waste solid would meet the intent of 10 CFR 60 . In the case of a $200 \mathrm{~L}$ drum (Figure 5.2), much lower leach rates are required. At this time, the configuration of the waste solid monolith is not known for the basalt repository scenario. For now, we assume that its SA/Vatio will be approximately that of a $200 \mathrm{~L}$ drum and that a $\mathrm{D}_{e}<10^{-16}$ and 
ORNL OWG 82-508

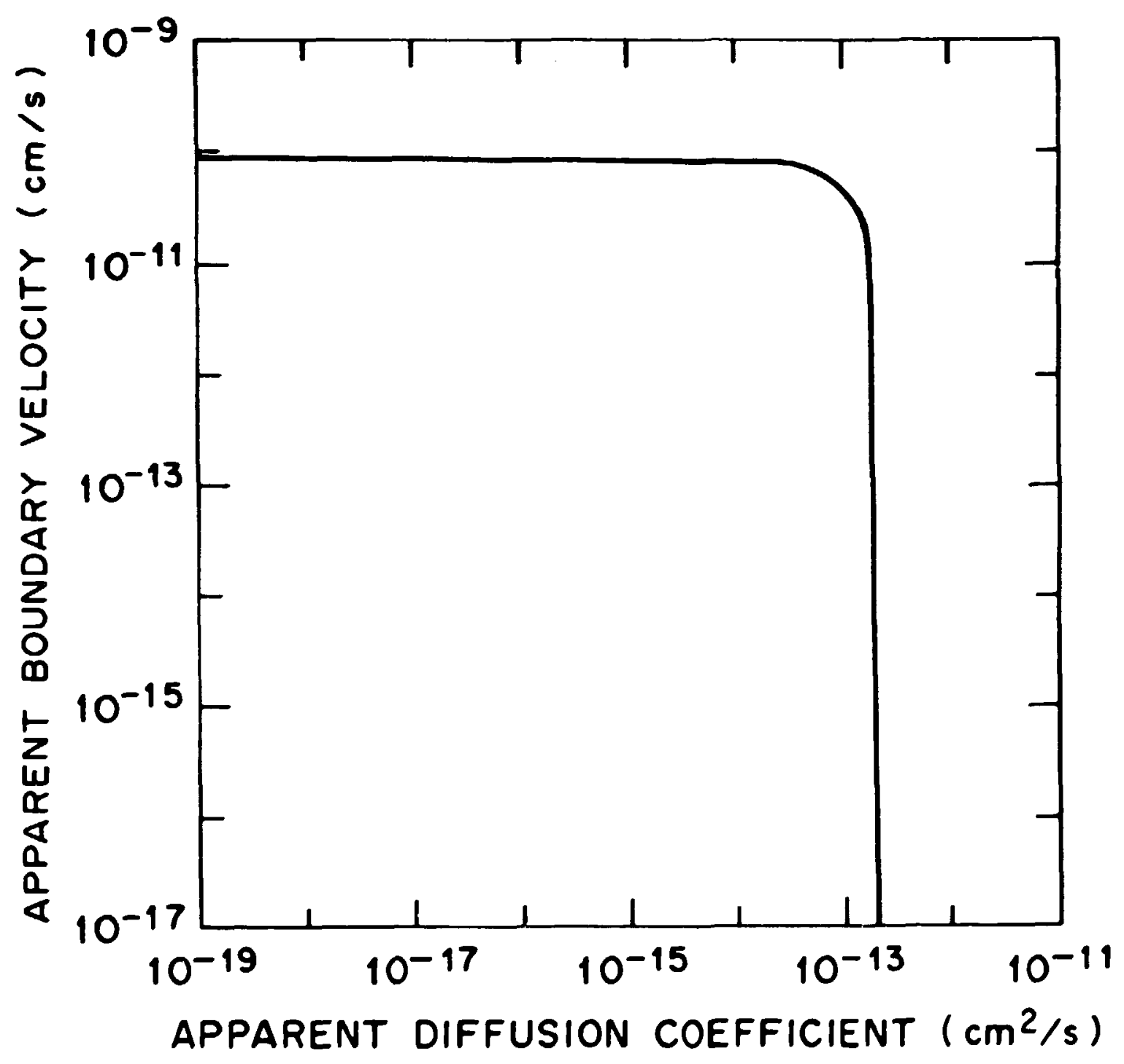

F1g. 5.1. Parameters necessary to obtain the maximum NRC release fraction of $1 \times 10^{-5}$ in 1 year from Hanford AX tank (dimensions $75 \mathrm{ft}$ diam $x 36.5$ ft high). 
ORNL DWG 81-455R

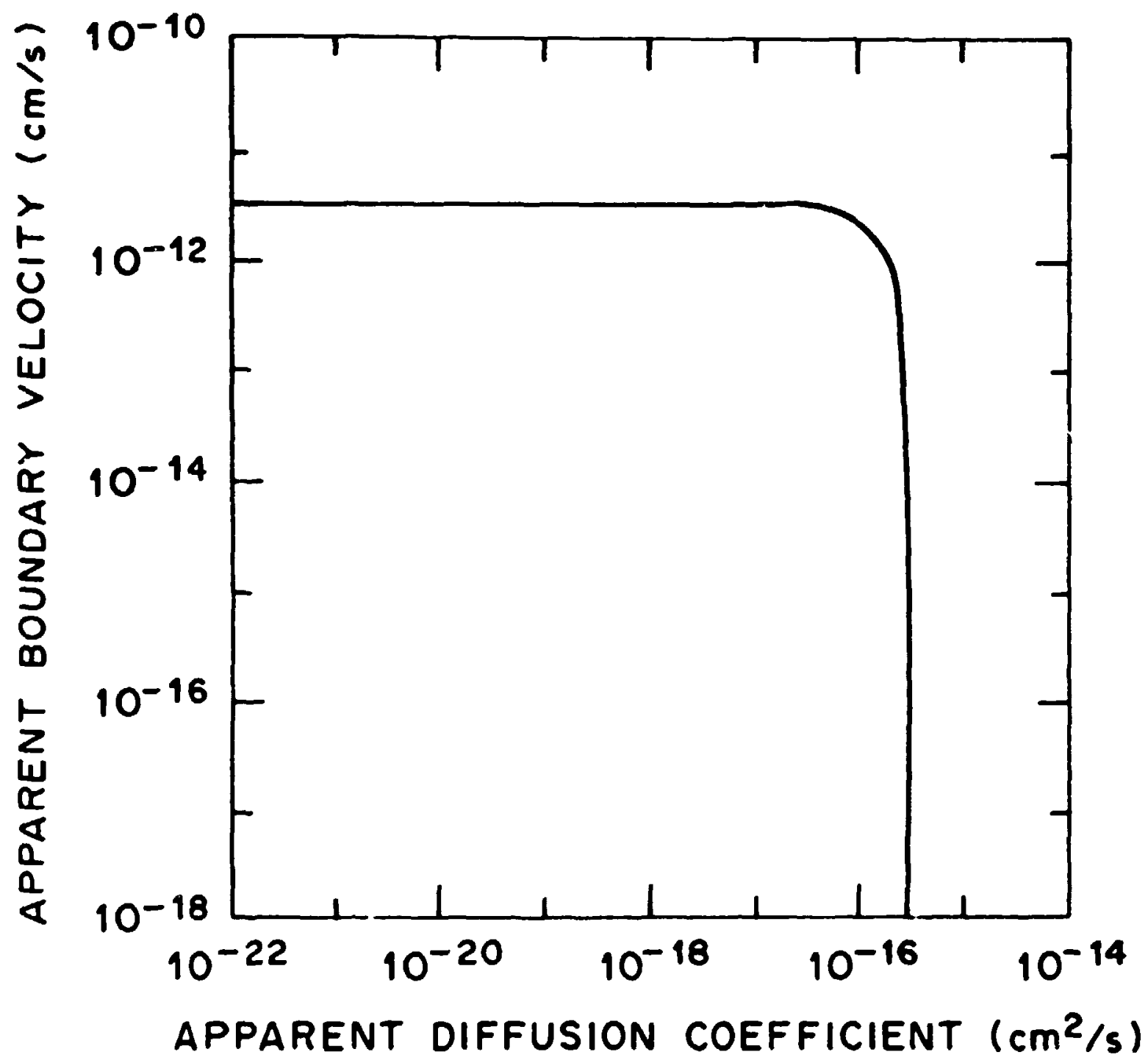

Fig. 5.2. Parameters necessary to obtain the maximum NRC release fraction of $1 \times 10^{-5}$ in 1 year from standard $200-\mathrm{L}$ drum. 


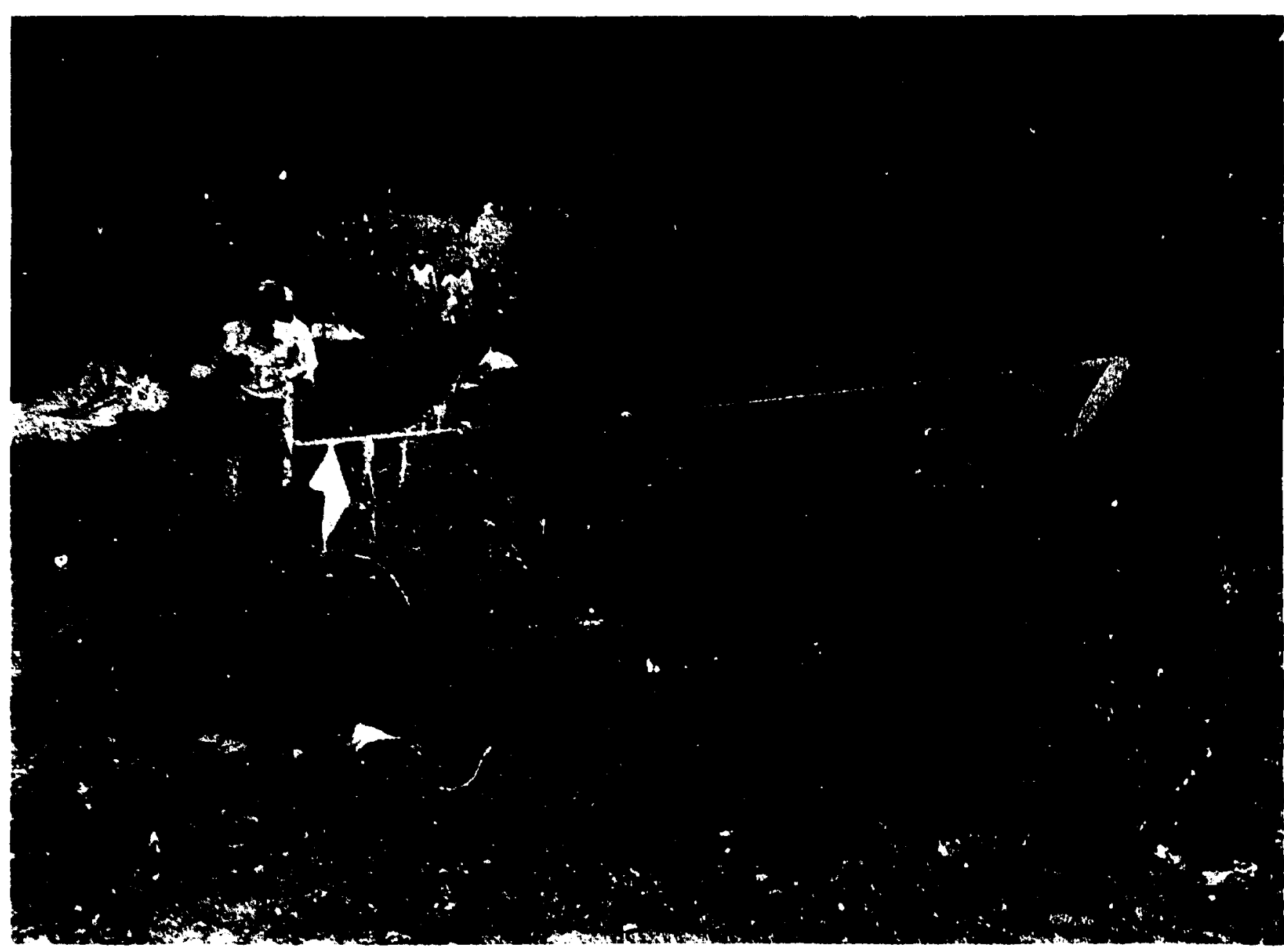

$\because 1 \% \cdot 4.2$. Fxcavation for Removal of ILW Transfer Lines from White Oak Creek and Floodplain. View fook $1 \mathrm{ng}$ winl loward white Oak Creek from the old Hydrofracture Fac1llty. Excavation in foreground has :and :artlally closed, and removal of plpes is in progress near the creek. 


\section{$61 / 62$}

a $R<10^{-12}$ will be required. ORNL has shown that the present hydrofracture grouts and autoclaved concretes satisfy these performance

requirements .

\subsection{PUBLICATIONS}

None.

5.4 REFERENCES

None. 


\subsection{DOE LOW-LEVEL WASTE MANAGEMENT PRDGRAM}

\section{J. Mezga}

\section{1 .1 - INTRODÜCTION}

In early FY 1979 Oak Ridge Narional Laboratory was assigned the associate lead contractor role in the DOE Low-Level Waste Management Program (LLMMP). This role is carried out under the overall management of the Program Manager at DOE's Idaho Operations Office, the lead contractor, (EG\&G Idaho) at the Idaho National Engineerirg Laboratory, and DOE's Oak Ridge Operations office.

The overall objective of the LLWMP is to develop and promote environmentally sound techniques for safely and efficiently managing the disposal of all types of low-level wastes (LLW).

LLW results from such activities as energy production, manufacturing, and the use of radioisotopes in medical and research activities. Specific program technology objectives include the development of waste treatment and packaging technology; development of Improved shallow land burfal technology; establishment of corrective measures for stabilizing and lmproving performance of existing burial grounds; Identification and evaluation of alternative methods for storage and disposal of LLW that provide greater confinement than shallow land burlal; and devẹlopment of guldelines or standards for waste characterlzation, disposal, and monitoring. 
The Oak RIdge National Laboratory (ORNL) in its role as associate lead contractor of the DOE LLWMP has responsibility for the management of progran-funded technology development activities. In this role with general guidance provided by DOE and the lead contractor (EG\&G Idaho), the ORNL progran office is charged with the responsibility to

(1) deveiup progran plans for the major technology areas, (2) recommend allocations for the progran resources, (3) review the technology development tasks to ensure that program objectives are being met, and (4) to sssist the lead contractor in coordinating the DOE LLMP with other on-going U. S. and foreign waste technology programs. Although the ORNL office generally assists the lead laboratory in management of the total program, our emphasis is on management of R\&D for development of basic technology and to assess concepts for alternative systems of processing and disposal of LLW.

\section{1 .2 - PROGRESS}

Technical progress for each of the tasks of this program for FY 1982 follows.

\subsubsection{Low-Level Waste Management (L. J. Mezga, R. B. Fltts.} M. S. Moran, W. H. Pechin, L. E. Stratton, and D. J. Wilkes)

\subsection{Technical. Planning}

Detalls for the technology development portions of the LLWM FiveYear Program Plan were developed in conjunction with EG\&G Idaho. The actual issuance of the detalled overa1l Program Plan for FY 1982 was 
carried out by BG\&G Idaho. The following reviews of technology status were prepared by this office in support of progran planning and control:

- Revision of Posftion Paper: "Evaluation of the Need for Greater Confinemen, than Shallow Land Burial of Low-Level Hastes" (L. J. Mezga),

- Final Report: "Review of Liquid Waste Treatment Processes Developed by the DOE LLWMP," ORNL/NFW $82 / 7$ (J. E. Vath), and

- Final Report: "Verification and Validation Protocols for Low-Level Waste Disposal Site Performance Models" (M. S. Moran).

In order to Insure that program outputs are of consistently high quality and delivered on schedule, the following program guidance was developed for technology development tasks:

- Guidance for the Preparation of Experimental Test Plans,

- Technical Guidance for the Preparation of FY 1983 Current Year Work Plans, and

- Technical Guidance for the Preparation of FY 1984 Field Task Proposals/Agreements.

\subsection{Resource A.llocation}

The major effort during FY 1982 focused on the devclopment and prioritization of the PY 1982, 1983, and 1984 budgets. These 
activities included: (1) preparation of FTF/A and budget call technical guidance, (2) evaluation and revision of FY 1982, 1983, and 1984 budgets, (3) evaluation and revision of the FY 1982, 1983, and 1984 Current Year Work Plans, and (4) priorltization of the FY 1982, 1983, and 1984 budgets. These were 1terative processes based on changes in the proposed budgets for these years and were made more complex because of the problems associated with operating under a continuing resolution.

\subsection{Program Review}

Program review activities during FY 1982 included: (1) conducting site visits to existing contractor facilities, (2) briefing DOE-HQ and field offices, and (3) conducting the Third- and Fourth-Annual Information Meetings. Site visits were conducted to review and discuss current fiscal year activities and to develop the elements of the Current Year Work Plan for the coming fiscal year. LLMMP staff provided guldance to the various contractors relative to program goals and technical needs, anticlpated funding levels, and program organization during these visits. The information galned during this exchange was used in evaluating and prioritizing the FY 1982, 1983 and 1984 budgets.

Information exchange and program coordination within the LLWMP occurred during the Third- and Fourth-Annual. Information Meetings held In New Orleans, Loulsiana on November 4-6, 1981, and Denver, Colorado on August 31 and September 1-2, 1982. The proceedings of the third annual meetIng were published as ORNL/NFW-81/34. The proceedings of the fourth annual meeting are in press. During these meetings, the 
various contractors reported on the status of projects funded during the current fiscal years (FY 1981 and 1982). A series of workshops were held during the third annual weeting to obtain input fron the contractors regarding research needs and progran approach. The fourth annual meeting consisted almost entirely of snall group, technical sessions to maximize information exchange and discussion among the participants. The audience for this meeting was expanded to include representatives of USNRC, USEPA, USGS, several states, and private consultants and facility operators. Contractors from all four faderal agencles presented reports on their work allowing for better coordination and understanding of the federal program.

\subsection{Coordination With Other Waste Technology Programs}

Information exchange and program coordination with other DOE and federal waste programs continued. In addition to the major effort on coordination with other federal waste programs that occurred at the Th1rd- and Frourth-Annual DOE LLWMP Program Particlpants' Meetings, the ORNL LIWM program office participated in an inceragency meeting on the application of models to low-level waste disposal held In Germantown, Maryland, June 15, 1982. This meeting brought together representatives from the U. S. Department of Energy, U. S. Environmental Protection Agency, U. S. Geologic Survey, and U. S. Nuclear Regulatory Commission. Coordination with other defense waste programs was maintained through particlpation in the lleadquarters Field Coordination Meeting. In addition, a memorandum of agreement was developed between the DOR LLWM and IRU Programs 1dentifying areas of programmatic intersction 
related to greater confinement disposal. To that end, TRU Program representatives participated in the Fourth Annual Participants Meeting.

\subsubsection{S1te Participation}

This task provided support for the Third and Fourth Annual DOE LIWMP Participants Meetings. These activities are discussed in section 7.1.2.1.3 Program Reviéws.

7.1.2.3 Corrective Measures Handbook (L. E. Stratton)

\subsection{Corrective I'easures Criteria}

Draft Corrective Measures Criteria were prepared and submitted to EG\&G Idaho in July 1982, two montins ahead of schedule, for use as part of DOE Grder 5820. This completed ORNL's effort on the criteria. The Corrective Measures Criteria provide standards for addressing problems encountered with the shallow land burial of low-level radicantive waste by identifying threshold levela which require corrective measures to improve disposal site performance. In developing the criteria, an initial working draft was prepared and a review committee was formed with representation from the DOE, the states, and the commercial sector. The committee recommendations were used as foundation principles for developing the criteria.

The draft corrective measures criteria provide for correction of conditions that could jeopardize performance objectives of a site. Conditions covered in the criteria are: (1) wind and water erosion, 
ponding or flooding, (2) accunulation of water in trenches, (3) plant or anteal Intrusion, and (4) chenical or biological reactions.

\subsection{Corrective Measures Handbook}

The Corrective Measures Handbook describes the experience of shallow land burfal site operators with the implementation of corrective measures to ellatnate conditions that result, or could result, in the site's faflure to neet its stated performance objectives. The report provides operators with documentation of previous efforts to correct conditions comon to several SLB disposal sites that result in inadequate site performance. As such, the report Is a "state-of-the-art" document and w1ll be the reference point for the final Corrective Measures Handbook.

The report 18 based on a literature review and on fisits to six DOE and five comercial disposal sites. Experience Indicates that the most effective corrective actions are those developed based on an understanding of the site conditions which caused the problems. Accordingly, the report 18 organized by causative factors (1.e., conditions that have resulted in probler... These factors include: (1) unstable trench cover, (2) permeable trench cover, (3) subsidence, (4) groundwater entering trenches, (5) intrusion by deep-rooted plants, (6) Intrusiun by burrowing animals, and (7) chemical and physical conditions in the trench. In discussion of each, the condition 18 briefly introduced and 18 followed by an itemization of actions to correct the condition. 
A peer refiew comittee was created with representation from both DOE and comercial disposal facility operators. The comittee reviewed the report and their recomendations were incorporated. The current practices corrective neasures report titled, "Prefious Experience and Related Research and Development In Applying Corrective Measures at the Major Low-Level Radioactive Waste DIsposal Sites," was conpleted in September 1982 as scheduled.

\subsubsection{PUBLICATTONS}

D. E. Large, R. S. Lowrle, L. E. Stratton, and D. G. Jacobs (editors), 1981. Proceedings of the Third Annual Information Meeting, DOE Low-Leve1 Waste Management Program, November 4-6, 1981, New Orleans, Loulsiana, ORNL/NFW-81/34, 586 rages.

D. E. Large, L. E. Stratton, L. J. Mezga, R. R. Rose, Compilers, 1982. Proceedings of the Fourth Annual Participants' Information Meet Ing, DOE Low-Level Waste Management Program, August 31, September 1-2, 1982, Denver, Colorado, ORNL/NFW-82/18 (in press).

\subsubsection{DEFERENCES}

None. 


\subsection{ORNL LOW-LEVEL WASTE PROGRAM}

N. H. CUTSHALL

\subsubsection{INTRODUCTION}

Projects, addressing the generic aspects of radioactive solid waste disposal, are carried out in the ORNL Low-Level Waste Research and Development Program. These include the evaluation and demonstration of improved burial procedures for future and existing disposal sites and the development and demonstration of corrective measures and strategies for site stabilization and closure. The federal regulation code (10 CFR 61) requires that all future commercial disposal sites be managed to meet a performance objective of no off-site groundwater contamination which would esult in a radiological dose above certain regulatory limits. To meet this requirement, certain sites may require engineered barriers, such as lined or grouted trenches, as improvements to the current practice of dump-and-ílll. Thus, a significant effort is under way to demonstrate and e raluate grouting and lining techniques. Even with good site planning and advanced burial techniques, the proposed regillations also require contingency plans for corrective actions should site performance be compromised by groundwater contamination. Techniques for groundwater contamination management, particularly for the more mobile radionuclides contained in the waste, need to be developed and demonstrated before generic recomendations for them can be advocated. Techniques under evaluation include a passive groundwater diversion system, remedtal trench grouting, and chemical treatment of trenches and groundwater seeps with caustic soda and soda ash. The final phase 
In the management of a waste disposal site is its stailization and closure. After closure, a site is abandened to the processes of geological weathering and vegetational succession through which perfod the site must still meet certain performance objectives. An evaluation of the interaction of weathering processes and vegetational succession with management techniques for final site stabilization is being pursued. Possible strategies to minimize these processes from compromising site performance need to be Identified so that the consequences of various strategies for site stabllization and closure can be predicted.

\subsubsection{PROGRESS}

Technical progres 3 for each task of this program for fiscal year 1982 follows

7.2.2.1 ORNL Corrective Measures (B. P. Spalding, M. G. Browman, E. C. Dav18, L. K. Hyder, D. S. Marehs11, I. L. Munro)

Shallow land burfal (SLB) has been and will continue to be the dominant disposal method for most low-level radioactive solid waste. SLB trenches usually perform well in retaining radionuclides and in preventing their migration to uncontrolled areas. Occasionally, trenches do leak radionuclides to the extent that corrective measures seem warranted. Problems with SLB including the infiltration of surface runoff into burial trenches, groundwater intrusion, trench subsidence, soll erosion, trench intrusion by plants and animals, and radionuclide migration, have been identified as potentially or actually leading to situations requiring corrective action. A 
hypothetical trench with all of these identified problems is depicted in Figure 7.2.1. The seasonal fluctuation of the water table leads to periods when the buried waste is bathed by groundwater. Additional inundation is facilitated by direct infiltration of precipitation and the catching of any surface runoff due to partial subsidence of the trench backfill. Points of rapid trench subsidence or cover collapse can effectively function as drains for surface runoff leading to an accumulation of water which results in a perched water table within the trench. Obviously, the control and diversion of surface runoff can alleviate many of these inundation problems. Trench cover sealing with bentonite or plastic sheeting has been advocated to relieve the situation of direct infiltration of precipitation $(7.2 .1)$. However, trenches like the one depicred in Figure 7.2.1 of ten are situated in areas where the water table is maintained by lateral groundwater recharge rather than, or in addition to, direct infiltration precipitation. Passive groundwater interception and diversion drains provide a means to relieve such situations.

Such engineered drainage alterations, however, can become economically prohibitive for large rogions containing many trenches, particularly when only one or a few trenches are the source of the problem. In these situations, hydrologic isolation of individual trenches can be addressed better by waste grouting. The infection of grout throughout the vold space of a burlal trench, which upon grout set becomes impermaable to water, can effectively isolate 
PAECIPITATION

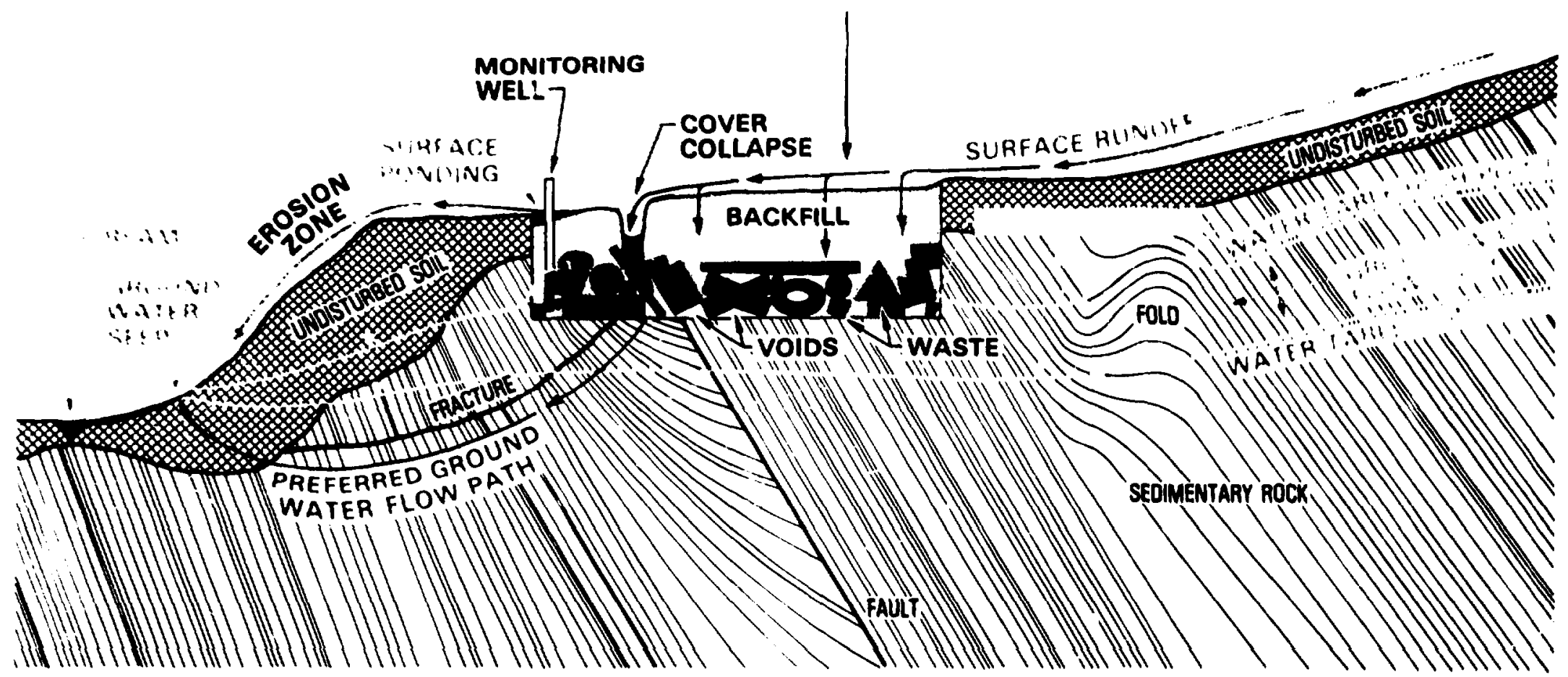

Fig. 7.2.1. Problems encountered in the shallcw land burlal of low-level waste to be iddressed by corrective measures technology. 
buried waste from further groundwater intrusion. In addition, since trench void spaces become filled, zubsidence can also be effectively controlled.

Mobility of radionuclides in low-level waste is the source of its potential hazard. One radionuclide, ${ }^{90} \mathrm{Sr}$, is particularly troublesome for SLB not only in a generic hazard evaluation because of its high radiotoxicity and its high mobilicy in soil but also at specific sites such as ORNL's waste disposal areas (7.2.2). Fixation or Immobilization of ${ }^{90} \mathrm{Sr}$ in soil, in and around a burial trench, has been pursued both in laboratory and field studies using caustic soda snd soda ash chemical treatment. Such chemical techniques would be mest applicable to situations where either groundwater diversion or grouting would be expensive. Treatments would also be applicable to groundwater seep contamination where an immediate abatement of radionuclide concentrations may be required. Treatment at a source trench may require a considerable interval before effects are observed at a distant contaminated seep.

The ORNL correctfve measures technology task is divided into four subtasks: a passive groundwater diversion dralnage demonstration, a trench grouting demonstration, a trench chemical treatment demonstration, and a groundwater seep treatment demonstration.

\subsection{Passive Drainage Demonstration}

This subtask addresses the situation where groundwater intrusion of a group of trenches is maintained by lateral recharge rather than by direct infiltration of precipitation. By constructing a groundwater intercepting and diverting drain between the area to be 


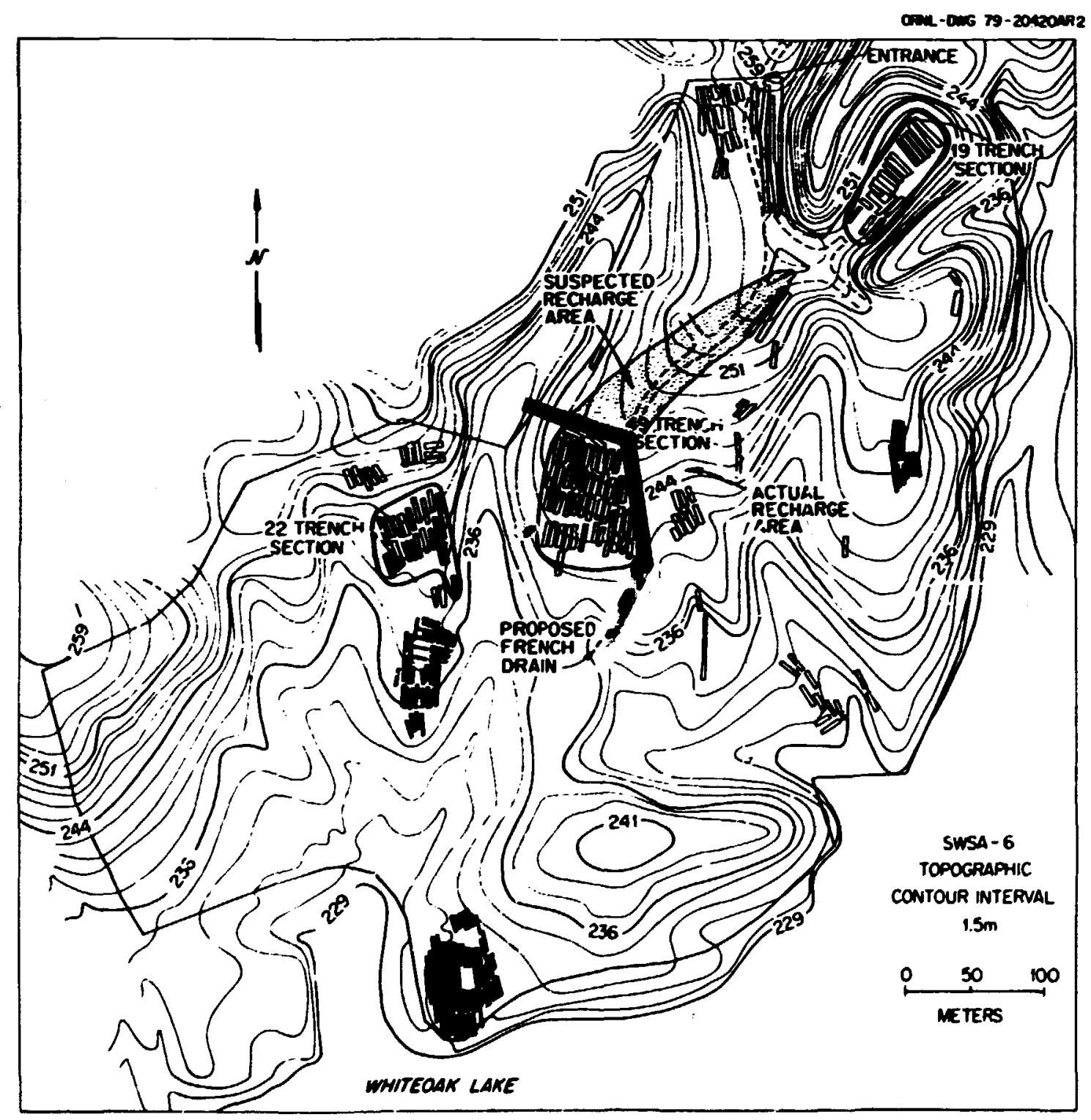

Fig. 7.2.2. Location of proposed french drain for groundwater diversion demonstration Solid Waste Storage Area 6 at ORNL. 
protected and its recharge area, the groundwater recharge can be eliminated. For purposes of a demonstraticn of this technology, a subsection of solid waste storage area (SWS $)$ ) 6 at ORNL, containing 49 burfal trenches, was selected as a site for cons.ruction of a french drain (Figure 7.2 .2 ). The suite of 49 trenches, to be protected by the drain, was surface sealed with a sull-bentonite mixture in November. 1976; however, seasonally standing water still exists in many of the trenches (7.2.3). Whether or not the bentonite seal is working in this area cannot be determined from observations of the water table alone; in addition to any infiltration of precipitation, allowed by a poorly performing seai, the water table in this area is maintained by lateral groundwater recharge from areas not under the seal. InterestIngly, based on the surface topographic contours and water table elevation data in the area (7.2.4), a traditional hydrologic analysis would indicate that the recharge area would be the shaded area in Figure 7.2.2. However, the area immediately east of these 49 trenches is probably more important as a recharge zone because it lies along the line of joint fractures in the area $(7.2 .5)$ which function as preferred grouridwater flow paths. Additional experimental determinations of the groundwater velocities and directions along the line of the proposed drain are being collected. Regardless of the relative contributions of these two possible recharge areas, the 49 trench area will be protected by the gurrounding drain. Test borings along the proposed drain have been completed and no hard rock was encountered within the 7.6 meter marimum depth of the dra:n. Construction will begin in the near future 
and, in the pre-construction interval, water table elevations will continue to be monitored to add to the existing five-year record of the area $(7.2 .4)$

\subsection{Tre Gh Grouting Demonstration}

This subtask addresses the situation where a particular trench, rather than a group of trenches, is functioning as a source of radionuclide groundwater contamination and, therefore, compromising the performance of a site. By the injections of a low viscosity and nonparticulate grout into the void space of a problem trench, the burfed waste can be hydrologically isolated after the grout sets to its impermeghle state. Two basic problems are faced by the potential grout user for any application as a corrective measure for low-level radioactive solid waste. Firstly, of the many grout types and formulations presently available (7.2.6), a selection must be made using criteria including a low-grout viscosity similar to that of water, a set time controllable from minutes to dyys, an Inherently low permeability after set, durability to resist the physiochemical and microbial stresses in its applied enviroment, low toxic hazard, and, of course, low cost. Any grout selection will, of necessity, represent a compromise among these properties. Based on existing data (7.2.6), five grout formulations were selected for laboratory testing; the fundamental property for this laboratory evaluation was the ability of the grout to reduce the hydraulic conductivity of several solls and waste types. Both $10 \%$ polyacrylamide and $15 \%$ sodium silicate performed well and were selected for field demonstration. 
The second problem to be faced by any grout user for such corrective measures application is how to achieve a distribution of the grout within the target trench. Since both the acrylamide and sodium silicate grost formulations are low viscosity and non-particulate, they would flow within trench volds as factlely as intruding groundwater. Therefore, grout injection could be effected with a ninimm number of injection wells; because the hydraulic conductivity of a trench's waste/backfill is wch greater than the surrounding unperturbed soll formation, trenches can be facilely filled with fluids. To test this critical assumption for waste grouting application, three disposal trenches were constructed in the suspect waste landfill area of SUSA 6. Trenches were filled with suspect solid waste and beckfilled with soil as SLB is currently practiced at ORNL. A grid of nine wells was positioned in each trench and each trench was surrounded by four additional wells within the unperturbed formation. By measuring the hydraulic conductivity of the material surrounding each of these wells through constant-head pump-in tests, grouting effectiveness can be determined by comparing before and after grouting measurements. The grid of wells, in addition to measuring the waste/backfill and soi $i$ formation conductivity, provides a means to determine the areal extent of grout penetration.

Both silfcate and polyacrylamide grouts were readily injected into the trenches and were observed in all monitoring wells. The hydraulic conductivities of all wells are dramatically reduced with more than $80 \%$ becoming effectively impermeable. Continuing monttoring 
of the permeability of each grouted trench will establish the longevity of their effectiveness.

\subsection{Chenical Trench Treatment Demonstration}

Treatment of trenches with caustic soda and soda ash can lead to a significant fixation or immobilization of ${ }^{90} \mathrm{Sr}$ which is 1ikely the most compromising radionuclide to the performance of a SLB site. Laboratory studies, employing both test tube batch and soil columns, have indicated that $\mathrm{Ca}\left({ }^{90} \mathrm{Sr}\right) \mathrm{CO}_{3}$ is an excellent phase to form in soll in-situ by the addition of soda ash and/or caustic soda $(7,2.7)$. A number of concerns remained about the applicability of this technique to acidic soils which are inherently low in available $\mathrm{Ca}$ from which $\mathrm{CaCO}_{3}$ would form on the addition of soda ash. Several acidic soils were treated with soda ash and supplemental $\mathrm{Ca}$ and $\mathrm{Ba}$ to supply adequate amounts of alkaline earths to effect a precipitation of $\mathrm{CaCO}_{3}$ or $\mathrm{BaCO}_{3}$, respectively. Soll columns were treated with ${ }^{85} \mathrm{Sr}$ and chemicals as described previously $(7,2.7)$ and eluted with dilute $\mathrm{CaCl}_{2}$. Supplemental $\mathrm{Ca}$ or $\mathrm{Ba}$ did effect a greater fixation of ${ }^{85} \mathrm{Sr}$ than soda ash alone. Thus a twc-step system for the chemical fixation of radiostrontium in strongly acidic solls would seem quite feastble and considerably broadens the range of solls to which the technique is applitcable.

The field demonstration of the trench treatment with caustic soda and soda ash, reported last year (7.2.8), hss continued in its monftoring phases. Little change in the trends of the observations reported then has occurred to the present. Hydrologic characterization of the trench 
ervirons has been attempted with some water pump-in tests. The resulting hydrologic characteristics will be used to evaluate the chenical behavior of this trench through time and will be used to formulate a model of the trench environs from which conclusions about trench performance beyond the period of experimental observation can be based.

\subsection{Groundwater Seep Treatment Demonstration}

This subtask addresses the situation where a groundwater seep is discharging radioactivity into surface water. Such a situation may require an immediate corrective action depending on the level of radioactivity involved. Source treatments, like the three techniques discussed above, could not result in an lnediate response at a seep discharge because the contamination plume, leading to the seep, could take several years to flush. Thus, even interim techniques to address sich situations have considerable merit. A seep on the periphery of SWSA 5 was selected for a field demonstration and a weir, stage height recorder, and autonatic water sampler were installed at the sfte. Af ter about a year of pre-treatment monitoring, $360 \mathrm{~kg}$ of soda ash was buried at seven locations immediately upslope from the seep and the response of ${ }^{90} \mathrm{Sr}$ and seep water quality were observed. Following soda ash burial, $\mathrm{pH}$ and electrical conductivity of the seep water increased markedly, while the hardness and ${ }^{90}$ Sr levels decreased concomitantly. An in-situ softening of this seep water, with the coprecipitation of ${ }^{90} \mathrm{Sr}$ on calcite, was brought about by this treatment. Average water quality parameters are presented in Table 7.2.1 the perfods 0-300 days 
before, 0-90 days after, and 91-310 days after soda ash $\mathrm{k}:$ rial. An average 807 reduction in ${ }^{90} \mathrm{Sr}$ concentration was maintained for the 90-day period following soda ash burial which was followed by a slow recovery to near, pretreatment levels over the next year. Thus, the technique has merit as an interin corrective measure, which could be repeated as often as necessary, while more perwanent corrective measures were carried out at the source. The major reason for its temporariness is the depletion of the soda ash via dissolution, neutralization, and calcite precipitation in the groundwater flow path. Since the inconing ${ }^{90} \mathrm{Sr}$ in groundwater was not stopped through a source treatment, once the soda ash was depleted, there was no mechanisa for continued radiostrontium fixation.

7.2.2.2 Shallow Land Burlal Technology Development. (N. D. Vaughan, G. T. Yeh, F. G. Taylor, N. H. Cutshall, I. L. Larsen, L. H. Stinton, O. M. Sealand)

The purpose of this task is to adapt, develop and demonstrate technical procedures that support the sha1low land burlal of low-1evel radloactive waste. Three subtasks have been fursued during the past year: 1) Advanced Burial Procedures, 2) Site Stabilization and C1osure and 3) Stte Selection Procedures Evaluation.

\subsection{Advanced Burial Procedures.}

The Engineered Test Facility (ETF), is a five-year field demonstration project of improved shallow land burial procedures. Site characterization and waste emplacement have been completed and monitorIng phases begun. 
Table 7.2.1 Average chenical characteristics of seep water in the periods before, 90-days after, asd greater than 90-days after soda ash treatrient of a groundwater seep.

\begin{tabular}{|c|c|c|c|c|}
\hline \multirow[b]{2}{*}{ Characteristic } & \multirow[b]{2}{*}{ Units } & \multicolumn{3}{|c|}{ Period* } \\
\hline & & $\begin{array}{l}0-300 \text { days } \\
\text { before }\end{array}$ & $\begin{array}{l}\text { 0-90 days } \\
\text { after }\end{array}$ & $\begin{array}{l}91-310 \text { days } \\
\text { after }\end{array}$ \\
\hline${ }^{90} \mathrm{Sr}$ & $\mathrm{Bq} / \mathrm{mL}$ & $7.37 a$ & $1.36 \mathrm{~b}$ & $5.34 c$ \\
\hline Hardness & $\mathrm{mgCaCO}_{3} / \mathrm{L}$ & $390 a$ & $83 b$ & $290 c$ \\
\hline Conductivity & $\mu \mathrm{S} / \mathrm{cm}$ & $638 a$ & $9000 \mathrm{~b}$ & $662 a$ \\
\hline pH & $-\log \left[\mathrm{H}^{+}\right]$ & $7.4 \mathrm{a}$ & $9.5 b$ & $7.6 a$ \\
\hline $\begin{array}{l}\text { Number of } \\
\text { Samples }\end{array}$ & - & 63 & 93 & 106 \\
\hline
\end{tabular}

* Means followed by the same letter are not significantly different at the $5 \%$ level. 


\subsection{Site Characterization. The ETF is located within} the Copper Creek thrust block of the Valley and Ridge Province of east Tennessee and is underlain by strata of the Middle to Lake Cambrian Conasauga Group. The Maryville Lfmestone formation, which is composed of ribbon-bedded and interclastic limestones and dark grey shales and mudstones, comprises the bedrock immediately beneath the site. The bedrock and residuum structure are characterized by anticlinal folds with numerous Joints and fractures, some of which are fulled with calcite. Seismic and electrical resistivity methods were useful in characterizing the thickness of residuun and presence of structural features. Solls are lliftic and range from podzolic to 1ithosols to alluvial in the vicinity of the ETF, but the original so11 solum was removed in 1975 when the mixed hardwood forest was cleared and the site was planted in grasses. The remaining residuum consists of acidic soll aggregate (pH 4.4 to 5.6 ) and extensively weathered siltstone and sandstone which exhibit the original rock structure. Mean annual precipitation at the site $181500 \mathrm{~mm}$, although during the initlal study period (10-1-80 to 9-30-81) the annual total was $939 \mathrm{~mm}$. Runoff was estimated to be approximately $50 \%$ of total precipltation based on observations at two Parshall flumes Installed at the site. Storm runoff is quite responsive to rainfall and the lag time between peak rainfall and runoff 18 less than 15 minutes during winter storms. Water quality of surface runoff 18 as expected for a mixed carbonate and siliceous terrain; except, there is tritium migration from an adjacent disposal area 
present in the flume to the east of the study area. Tracer studies of the groundwater system, together with pump tests, have shown the important influence of fractures and joints on groundwater movement at the site. The results to date suggest that groundwater flow has two distinct components; one associated with fracture flow and the other with Intergranular flow $(7.2,9)$.

7.2.2.2.1.2 Waste Emplacement. Waste emplacement consisted of waste-type selection, identification of specific Iiner and grout treatments, and actual emplacement. Compacted, baled low-level radioactive waste was chosen because of the quantity of waste needed for the triplicate demonstration-sized trenches $\left(\sim 27 \mathrm{~m}^{3}\right)$ for each treatment (control, grout and 1iner). These trenches were constructed in a Latin-square array within the space enclosed by the characterization wells. The bales were dumped as opposed to stacked into the trenches to simulate the voids normally found In low-level disposal trenches.

A $1.1 \mathrm{~mm}$ reinforced Hypalon material was selected as the 1 iner. It was placed into the trenches prior to the bales and then sealed shut after the trench was full. The grout used was composed of $0.45 \mathrm{~kg}$ bentonite and $2.75 \mathrm{~kg}$ Type 1 cement for every 3.78 11ters of slurry and was introduced after the waste was emplaced. These treatments are designed to retard water movement into the waste thus reducing subsequent radionuclide migration from the trenches and reducing trench substdence. Each trench had a unique chemical tracer placed in it at time of treatmant for sonftoring purpuecs. 
7.2.2.2.1.3 Monftoring. For the monttoring phase 24 wells were drilled with each trench surrounded by at least 4 wells. Samples are taken frrm the monitoring and characterization wells on a biweekly schedule to be analyzed for chemical or radionuclide contamination. Results Indicate that tracer breakthrough has not occurred in the first 4 months after closure.

An autouated data acquisition system has been developed for monitoring groundwater levels at the ETF site. The system employs a battery-operated data logging instrument that digitizes potentiometer output from water-level monitors in the 15 ETF wells, and records the digitized data on cassette tape at approximately 14-minute intervals. At one to two week intervals, the cassette is removed from the logger, and its contents are transferred onto a disk file on ORNL's PDP-10 computer. The raw data are preprocessed on the PDP-10 to convert from reverse octal to decimal millivolts. An interacive program prompts the user for the date, time, and calibration information associated with a given tape, and creates a raw data file for transfer to, and permanent storage, on the IBM Mass Storage Subsystem. A SAS (Statistical Analysis System) program that runs on the IBM 3033 converts the raw milivolt data to water-1evel elevations, associates these elevations with appropriate date-time information, and performs several checks for consistency of calibration and timing. The new data are added to a data base (stored as a'SAS data set) which contains all previously collected data in a form readily accessible for plotting and further data analysis, Including model valiu...ton. 
7.2.2.2.1.4 Burtal Site Transport Hodels. Numeious models using finite difference and finite element approaches for simulating the water flow and contaminant transport in either saturated-unsaturated porous media or in completely saturated aquifers have been reported In the 1iterature $(7.2 .10,7.2 .11)$ - However, none of the computational codes have been designed to simultaneously handle the transient sources/sinks, Dirichlet (prescribed head or concentration), Neumann (prescribed gradient of head or concentration), Cauchy (prescribed flux of water and contaminant), and variable boundary conditions (also confining leaky aquifers. in the case of completely saturated system). In real world, problems such as occur in disposal sites, recharge/ pumping, are more likely to be distributed over the region of Interest and to be time dependent. The boundary values, with rare exception, vary both with time and along a Dirichlet boundary. The prescribed gradients are bot! temporally and spatially distributed over the Neumann surfaces. The total fluxes vary with time and along Cauchy surfaces. Furthermore, in many occasions, the boundary conditions cannot be predetermined but change with the passage of time and with field conditions. Ior prototype applications, a compitational model must have the capability to deal with these aspects efficiently and simultaneously. Four computer codes, FEWA (7.2.12), FEMA (7.2.13), FEMWATER-1 $(7.2 .14)$, and FEMWASTE-1 (7.2.15) have been developed and implemented to achieve these objectives in the past year. FEWA and FEMA are intended for application to completely saturated aquifers over horizontal areas. This pair of models can be applied to largescale as well as small area problems. On the other hand, FEMWATER-1 
and FEMWASTE-1 are intended for applications to combined saturatedunsaturated porous media on a vertical cross-sectional area. They are more applicable to problems on a sca!e of hundreds of meters. They can be applied to larger-scale problems although computer storage requirements and central piocessing unit (CPU) time will be large. These four computer codes are developed and modified based on FEMFATER (7.2.16) aná FEMTASTE (7.2.17). The modifications will consider: (1) space and timedependent sources/sinks representing recharges and pumping; (2) highly transfent boundary values on Dirichlet segments; (3) time-dependent, distributed gradients over Neumann boundaries; (4) highly time dependent total fluxes on Cauchy boundaries: (5) addition of off-diagonal hydraulic conductivity to the water-flow equation; (6) options of under- and over-relaxation techniques in interation solutions; and (7) sutgatic resetting of time step size when boundary conditions or sources/sinks change abruptly. In addition, the input structure Is completely reformulated so that practitioners can use them easily. Modifications 1 through 4 make the model applicable to realis tic situations when internal sources/sinks and boundary conditions are changing with time either gradually or abruptly and are distributed over space. Modification 5 enables the application of these models to cases of geologic media consisting of several formations, each Is nonhomogeneous and anisotropic. Modification 6 extends modal applications to wider ranges of parameters when they make the numerical solutions fluctuate or converge too slowly. Modification 7 makes the schedule of time step size easy upon change of conditions. In addition, 
point-wise iterative computation is built in FEWA and FEMA as an alternative to the direct solution. This makes FEWA and FEMA applicable to large-scale problems because the requirement of large computer storage due to large band widtn of the matrix is relaxed.

\subsection{Site Stabilization and Closure}

Two factors that are critical to the long-term success of shallow land burial site closure are soil erosion and vegetation control.

\subsection{Soil Erosion Measurement. Post-closure soil erosion} may affect shallow land burial sites by reducing the integrity of trench covers, allowing infiltration into the trench and, in extreme cases, exposing the waste. Agricultural erosion work has previously led to development of the "universal soil loss equation" which estimates erosion rates based on precipitation, land surface slope, soil erodibility, etc. The USDA cosputer model, CREAMS, represents an advanced implementation of the universal soil loss equation. Dirert field measurements of erosion have been made to confirm the validity of the universal soll loss equation for relatively flat mid-western terrain. This subtask will determine if the validation can be generalized to a wider set of terrains. It is conducted in cooperation with Dr. G. A. Nellsen and Mr. O. Arnalds at Montana State University. Direct analysis of soll movement in the fleld is slow and expensive. Therefore, indirect trace methods have been developed to allow more rapid estimation of erosion and deposition. Cesium-137 was used ac a soll tracer in erosion studiez by Rogowski and Tamura (7.2.18). Their techniques have been adapted to ${ }^{137} \mathrm{Cs}$ from fallout atmospher ic 
weapons tests, refined and applied by McHenry $(7.2 .14)$, Ritchie $(7.2 .20)$ and coworkers and by Brown et al. (7.2.21, 7.2.22). These techniques will be used in variety of terrains in Montana, ranging from prairie farmland to high alpine and the results compared to estimates from the universal soil loss equation. A preliminary investigation has been completed and fallout ${ }^{137} \mathrm{Cs}$ appears to be a promising indicator of soil movement in Montana. In particular, two sets of samples have been analyzed. The first set was selected from a wind eroded field. A field which had been plowed just prior to a major historical windstorm was selected. Plow layer samples taken from the field itself were depleted in ${ }^{137}$ Cs reflecting the loss of soil that had occurred. Cesium-137 inventories in paired samples taken to the windward and leeward sides of windbreaks and fencerows downwind from the eroded field also showed the effects of soll movemint. Windward inventories are 1.5 to 2 times the leeward invencories showing the accumulation of soil that occurred.

The other set of samples were taken in a small watershed. Vertical profiles from four sites were determined (Table 7.2.2). A regular gradient in ${ }^{137} \mathrm{Cs}$ inventories is apparent. In the upper- and lower-slope areas which are subject to erosion, ${ }^{137} \mathrm{Cs}$ inventories are markedly lower than the pond at the bottom of the watershed. Thus, it appears that the results are qualitatively consistent with expectation. Approximateiy 200 samples are now being analyzed for ${ }^{137} \mathrm{Cs}$, and the results w11 be used to make quantitative estimates of soll removal and deposition. 
Table 7.2.2. Montana watershed fallout ${ }^{137}$ Cs Distribution. Cesium-137 and soil are depleted from the upper slope and deposited in the pond.

\begin{tabular}{|c|c|c|c|c|c|c|}
\hline \multirow[t]{2}{*}{ Site } & \multirow{2}{*}{ Slope } & \multirow[t]{2}{*}{$\begin{array}{l}\text { Segment } \\
\text { Thickness } \\
\text { (inches) }\end{array}$} & \multicolumn{4}{|c|}{$\frac{{ }^{137} \mathrm{Cs} \text { Concentration } \mathrm{pCi} / \mathrm{g}}{\text { Segment }}$} \\
\hline & & & Upper & Center & & Lower \\
\hline Upper slope & $5-7$ & 6 & .17 & .08 & Not & sampled \\
\hline Lower slope & $1-3$ & 6 & .59 & .13 & Not & sampled \\
\hline Grass near pond & flat & 5 & .84 & .48 & & .07 \\
\hline Pond, center & flat & 5 & .72 & .65 & & .53 \\
\hline
\end{tabular}


7.2.2.2.2.2 Vegetation Studies in Humid Site Stabilization and Closure. Long-term stabilization and minimization of maintenance requirements are desirable components of closure for shallow land burial sites. State-of-the-art protocols utilizing grass as cover to inhibit invasion of undesirable species are labor-intensive and not suitable for the long term. A more desirable vegetative cover would employ phases other than pioneer stages (grasses) and would persist for many years with only periodic maintenance. Considering the diverse floristic composition of the humid eastern United States, no single taxon is likely to provide an ideal cover. Succession models can identify potential cover types (grasslands, thickets, forests) that can be manipulated (maintained) to prolong dominance.

P=eliminary work with simulation models indicutes plantations of certain early successional arboreal species may provide suitable vegetation cover while requiring infrequent, labor-intense manipulation. Species such as red maple or white ash have proper rooting characteristics, sprout readily when harvested, and can regenerate and maintain growth, through coppicing (stump sprouting) on a 20-year cycle, while providing high leaf areas suitable for relatively high evapotranspiration. Current work indicates highly variable growth under different moisture and nutrient regimes. The use of solely successional models, however, oversimplifies the temporal character of a cover in simulated studies. Addition of moisture and nutrient subroutines in model studies, superimposed upon manipulative practices, 
will provide design criteria in cover recommendations throughout the southeast.

From an initial selection process, red maple and white ash represent choices for plot studies to bigin next year. Efforts will be combined with site-specific research to evaluate the species ability to cover an area, interaction with invading (competing) species, and persistence without intense maintenance.

\subsection{Site Selection Procedures Evaluation}

During FY 1982 work was initiated on the Site Selection Procedures Evaluation Subtask. The subtask goal was to demonstrate the application of site selection criteria developed by DOE to a specific region - the Oak Ridge Reservation. Generally, the site selection process consists of two stages - site screening and site characterization. Site screening activities are based on reconnaissance level data such 38 published or unpublished reports, existing records, and brief field surveys. Site screening culminates in the identification of a preferred site. Site characterization entails the evaluation of the preferred site to confirm that the site characteristics will meet the specified performance standards. Significant site data and analysis are required to confirm site performance. Generic site selection procedures were identified covering the entire site selection

process. The availability of information at the Oak Ridge site required that the specific site application concentrate on the site screening stage. 
Initially the work was designed to use a computer code for site selection evaluation. However, upon reviewing existing computer codes for selecting a low-level waste disposal site, none were directly applicable at the sfte screening stage. Several models were available for site characterization; but, if these were forced into service for site screening, the data assumptions and model manipulations required would leave little credibility in the results. A generic site selection methodology was developed to pruvide a framework for applying the DOE criteria to the Oak Ridge Reservation.

Upon reviewing existing site selection criteria and procedures, a generic methodology was documented. The methodology was generally adapted frow state-of-the-art siting strategles and taflored for the specific needs of low-level waste disposal and the DOE site selection criteria. In general, the site screening involved defining the region of interest, identifying candidate areas and sites, and ranking candidate sites to identify the preferred site. The site selection strategy is summarized in Figure 7.2.3. The detailed logic for each activity was also developed. The logic includes provisions for 1terations and paths of recourse within the methodology in case the preferred site is found to be unacceptable.

Work was also inftiated on applying the methodology to the Oak Ridge site and comparing the results to previous siting studies completed on the reservation. These activities will be completed during the first quarter of FY 1983. 


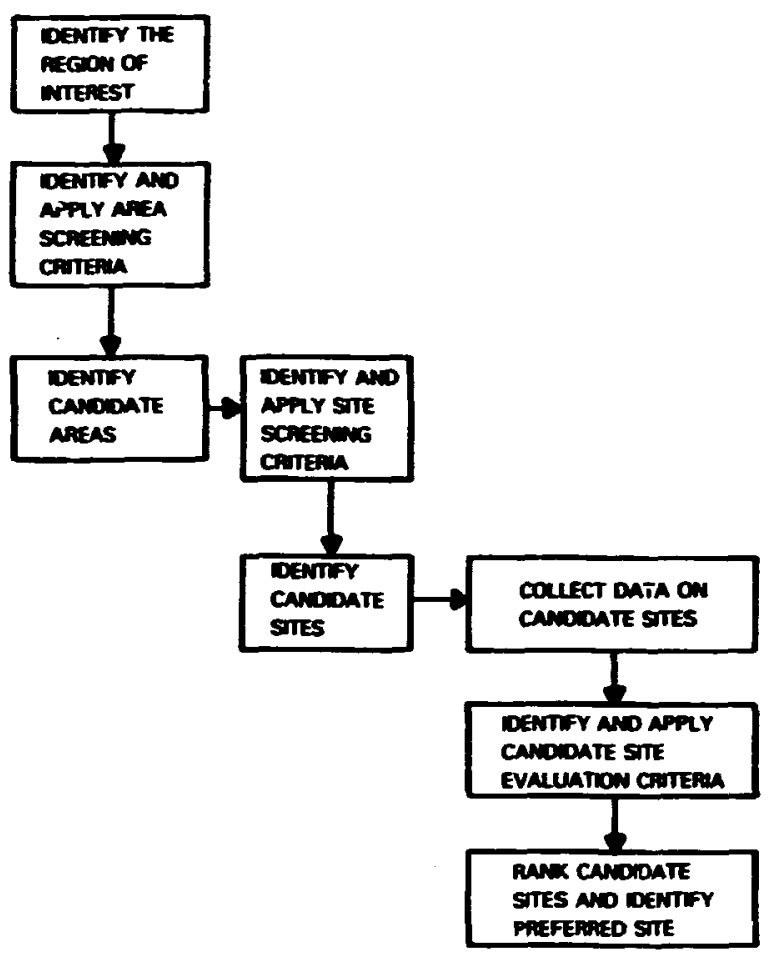

Onish-Ong ex-196e

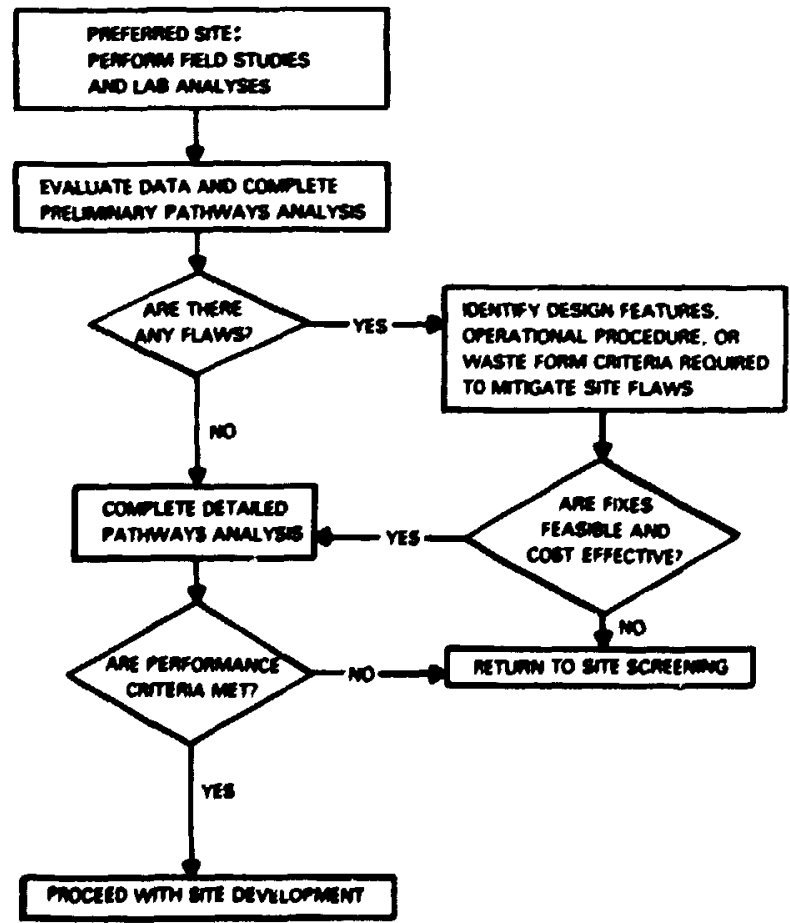

Fig. 7.2.3. Logic flow for shallow land burlal site selection procedures. a) Siting screening, b) characterization. 


\subsubsection{US/FRG Cooperative Program. (L. R. Dole, G. C. Rogers, and}

This task is directed toward a cooperative research and development program and information exchange on low-level waste disposal with the Federal Republic of Germany concern*ig in-situ solidification of low-level waste for disposal in salt cavities or other geological formations. Research has been initiated to determine the feasibility and applicability of this procedure as an alternative technique to shallow land burial. The tasks include: (1) consultation and information exchange with the FRG, (2) data assessment for applicability to shallow land burial, and (3) establishment of a cooperative research and development program.

Funding for this task ended after 3 months of FY 1982 and the work was terminated.

\subsubsection{Decontamination Effectiveness. (G. L. Copeland)}

Work on this program ceased in January when the program was canceled. At this potnt, information gathering for the literature survey was complete, and preparation of the report had startec Another aspect of the program was to provide more detailed analysis of ingots and slag produced during the demonstration melting at the Paducah Gaseous Diffusion Plant of 100 tons of contaminated steel. About 15 tons of steel were melted before suspected liner erosion caused melting to be stopped. These 15 tons of steel were cleared to about $1 \mathrm{ppm}$ uranium. This program was canceled during the delay in melting, and the planned doping of scrap with $C_{\text {B }}$ and $\mathrm{Sr}$ was not accomplished. 


\subsubsection{Shallow Land Burial Handbook}

Additional disposal facilities are needed to accommodate the low level radioactive wastes being produced by both comercial and defense activities. One of the purposes of DOE's Low-Level Waste Management Program is to "develop the technology and documentation required to open a shallow land burial site." The Shallow Land Burial Handbook provides support for this goal by transferring state-of-the-art information about shallow land burial technology to the user community. The handbook gives developers and state or local planners an overview of and infitial guidance for undertaking the development of phases and activities required for establishing new facilities for near-surface disposal of low-level radioactive waste. These activities, carried out from the first feasibility studies through closure and postclosure, include defining and establishing the scope of the problem, establishing objectives, compiling information, considering alternatives, and establishing and implementing plans.

This document went through several revisions and review cycles during FY 1982. Reviews of the final product indicate an acceptable document which should be useful to the U.S. Department of Energy and others in the government and private sector. 


\subsubsection{Lor-Level Haste Treat-ent Handbook}

The objective of the Low-Level Waste Treatment Bandbook 18 to present an overviev of current practices related to the segregation, classification, voluse reduction, solidification, handling, packaging, and transportation of low-level radioactive waste for disposal in a shallow land burial facility. The handbook is intended to serve as a guide to Indifiduals who have no previous knowledge in handing lowlevel wastes and who need an Introduction to the available technology and regulations.

The growing concern with low-level waste disposal has focused attention on methods for reducing the volumes being generated. One method of volume Animization 18 to exercise better administrative controls to limit the production of waste, such as contaminated dry trash. Volume minimization can also be achleved by more efficient waste treatment options; however, maximum volume reduction will dictate equipment modifications involving capital investment and licensing considerations. The commercial introduction of more sophisticated systems such as incineration for combustible wastes can significantly reduce the low-level waste volumes for disposal. Since waste characteristics and volumetric burlal charges are unique to each generator, cost-effective waste treatment procedures will have to be developed on a site-specific basis.

The handbook describes low-level radioactive waste treatment from source to ultimate disposal, including an introduction to the waste treatment problem, the bources and characteristics of low-level wastes; treatment and volume reduction techniques for both liquid and dry wastes, including fon exchange, evaporation, filtration, reverse osmos's, compac- 
tion, incineration, and dehydration; low-level waste solidification techniques, including a discussion of sorbents, cement, bitumen, and organic polywers; and packaging and transport of low-level waste to the disposal facility. To reflect comercially avallable technology, Gilbert Associates, Inc., was subcontracted to address the comercial status of low-level radioactive waste treatment and handling procedures.

\subsubsection{PUBLICATIONS}

T. E. Cerling, and B. P. Spalding. "Distribution and Relationship of Radionuclides to Streambed Gravels in a Small Watershed," Environ. Geo1., (in press).

₹. E. Cerling and R. R. Turner. 1982. "Formation of Freshwater Fe-Mn Coatings on Gravel and the Behavior of ${ }^{60} \mathrm{Co},{ }^{90} \mathrm{3r}$ and ${ }^{137} \mathrm{Cs}$ in a Sma11 Watershed," Geochim. et Cosmochim. Acta, 46:1333-1343.

N. H. Cutshall, N. D. Vaughan, C. S. Haase, C. R. Olsen, and D. D. Huff. 'Hydrologic and Geologic Aspects of Low-Level Waste Site Management," Proc. International Conference on Radioactive Waste Management, Winnepeg, Manitoba, Canada, Sept. 12-15, 1982, (in pres8).

B. P. Spalding and D.D. Huff. 1981. "Remedial Action Technology for Humid Sites," pp. 437-466, Proceedings of the Third Annual Participants Information Meeting, DOE Low-Level Waste Management Program, ONL/NFW-81/34. Oak RIdge National Laboratory, Oal Kidge, IN

B. P. Spalding and W. A. Hoffman, Jr, 1982. So11 Radiochromatography using ${ }^{22} \mathrm{Na},{ }^{85} \mathrm{Sr}$, and ${ }^{58} \mathrm{Co}, 0 R \mathrm{RL} / \mathrm{MM}-3138.44 \mathrm{pP}$.

B. P. Spalding. 1982. "Research Efforts on Environmental Transport of Hazardous Materials at Oak Ridge National Laboratory," Trans. Amer. Nuc. Soc., 41:66. 
B. P. Spalding, M. G. Browman, and E. C. Davis, "Correcitve Measures Technology for Hunid Sites," Proc. of the Fourth Annual Participants Information Meeting, DOE Low-Level Waste Maisagement Program, ONL/NFW-82, (in press).

N. D. Vaughan and N. H. Cutsha11. "SLB Technology-Humid". Proceedings of the Fourth Annual Particlpants Information Meeting, DOE Low-Level Waste Management Program, ONL/NFW-82, in press.

N. D. Vaughan, C. S. Haase, D. D. Huff, S. Y. Lee, and E. C. Walls, Field Demonstration of Improved Shallow Land Burial Practices for Low-Level Radioactive Solid Wastes: Preliminary Site Character1zation and Progress Report, ORNL/TM-8477, in press.

G. T. Yeh, "Computation of Darcian Veloc:-y and Mass Balance in the Finite Element Modeling of Groundwater Flow," Water Resource Research, Vo1. 12, No. 5, 1529-1534.

G. T. Yeh and T. Tamura. "Geohydrochemical Consideration in Land Disposals of Low-Level Wastes," Nuclear Sctences and Engineering, Volume 82, No. 2, 206-219.

G. T. Yeh and R. J. Luxmoore. "A Mult1-Dimensional Model for Simulating Moisture and Thermal Transport in Unsaturated Aquifer Systems," Modeling and Simulations, Vol. 12, No. 1, p. 61-66, Instrument Society of America Research Triangle Park, N.C.

G. T. Yeh and R. J. Luxmoore, "Chemfcal Transport In MacroporeMesopore Med Ia Under Partially Saturated Conditions," Sympostum on Unsaturated F1ow and Transport Modeling, Seattle, Washington, March 23-24, 1982, p. 267-282, Nuclear Regulatory Commisston, Washington, D.C. 
G. T. Yeh, CHNHYD: A Channel Hydrodynamic Model for Simulating Flows and Water Surface Elevations in Stream/River Network, ORN-5701, ESD Publication No. 1686, Oak Ridge National Laboratory, Oak RIdge, Tennessee, January 1982, pp. 123.

G. T. Yeh and R. H. Strand. FECWATER: User's Manual of a Finite Element Model for Simulating Water Flow through Saturated-Unsaturated Porous Media, ORNL/TM-7316, ESD Publication No. 1523, Oak Ridge National Laboratory, Oak Ridge, TN.

G. T. Yeh, "Simulations of Flows and Water Depth in Dendritic River System," International J. Numerical Methods in Fluids.

G. T. Yeh and R. J. Luxmoore. "Modeling Motsture and Thermal Transport in Unsaturated Porous Media," J. Hydrology.

G. T. Yeh and R. H. Strand. FECWASTE: User's Manual of a Finfte Element Code for Simulating WASTE Transport Through Saturated-Unsaturated Porous Media, ONL/TM-8104, Oak Ridge Nationai Laboratory, Oak RIdge, TN.

G. T. Yeh, CHNTRN: A Channel Transport Model for Simulating Sediment and Chemical Distribucion in a Stream/River Network, ORNL-5882, Oak RIdge, TN.

G. T. Yeh and R. J. Luxmoore, MATTUM: A Mult1-Dimensiona1 Model for SImulating Moisture and Thermal Transport in Unsaturated Porous Media, ORNL-5888, Oak Ridge National Laboratory, Oak RIdge, TN.. 


\subsubsection{REFERENCES}

1. J. 0. Duguid, Annual Progress Report on Burial Ground Studies at Oak Ridge National Laboratory: Period Ending September 30, 1975 ORNL-5141. 54 p. 1976.

2. J. 0. Duguid, 1975. Status Report on Radioactivity Movement from Burial Grounds in Melton and Bethel Valleys. ORNL-5017. 66 p.

3. H. S. Arora, D. D. Huff, D. S. Ward, and 0. M. Sealand, 1981. An Assessment of a Bentonite Seal on Groundwater Storage in Underlying Waste Disposal Trenches at ORNL. ORNL/TM-7416. $52 \mathrm{p}$.

4. D. A. Webster, J. S. Beatty, P. M. Benjamin, and W. M. Tranum, 1980. Water Level Data for Wells in Burial Ground 6, Oak Ridge Nationa1 Laboratory 1975-79. USGS Open-file Report 81-57.

5. J. J. Sledz and D. D. Huff. 1981. Computer Model for Determining Fracture Porosity and Permeability in the Conasauga Group. ORNL/TM-7695. $238 \mathrm{p}$.

6. J. Herndon, and T. Lenahan, 1976. Grouting of Solls. Vol. 1. A State-of-the-Art Report. PB-259-043. NTIS. 286 p.

7. B. P. Spalding, 1981. Chemical Treatments of Soll to Decrease Radiostrontium Leachability. J. Environ. Qua1. 10:42-46.

8. B. P. Spalding and D. D. Huff, 1981. Remedial Action Technology Development for Humid Sites. p. 437-446. In Proceedings of the Th1rd Annual Information Meeting, DOE Low-Level Waste Management Program. ONL/NFW-81/34. 586 p. 
9. N. D. Vaughan, C. S. Haase, D. D. Huff, S. Y. Lee and E. C. Walls, Field Demonstration c.f Improved Shallow Land Burial Practices for Low-Level Radioactive Solid Waste: Preliminary Site Characterlzation and Progress Report, ORNL/TM-8477 (in press).

10. C. A. Appel and J. D. Bredehoeft. 1976. Stalus of Groundwater Modeling in the U.S. Geological Survey. Geological Survey Circular 737, U.S.G.S., Reston, VA. pp. 9.

11. Y. Bachmat, J. Bredehoeft, B. Andrews, D. Holtz, and S. Sebastian. 1980. Groundwater Management:. The Use of Numerical Models

Water Resources Monograph 5, Americar Geophysical Union, Washington, D.C. pp. 127.

12. G. T. Yeh, and D. D. Huff. 1982a. FEWA: A Finite Element Model of Water Flow through Aquifers, Oak Ridge National Laboratory, Oak Ridge, TN, (in preparation).

13. G. T. Yeh and D. D. Huff. 1982b. FEMA: A Finite Element Model of Material Transport through Aquifers. Oak Ridge National Laboratory, Oak Ridge, TN (in preparation).

14. G. T. Yeh, 1982a. FEMWATER-1: A Finite Element Model of Water Flow through Saturated-Unsaturated Porous Media - first revision. Oak Ridge National Laboratory, Oak Ridge, TN (in pre,aration).

15. G. T. Yeh, 1982b. FEMWASTE-1: A Finite Element Model of Waste Transport through Saturated-Unsaturated Porous Media - first revision. Oak Ridge National. Laboratory, Oak Ridge, TN (In preparation). 
16. G. T. Yeh and D. S. Ward. 1980. FEMATER: A Finite-Element Model of Water Flow through Saturated-Unsaturated Porous Media. ORNL5567, Oak Ridge National Laboratory, Oak Ridge, TN pp. 153.

17. G. T. Yeh and D. S. Ward. 1981. FGMASTE: A Finite-Element Model of Waste Transport through Saturated-Unsaturated Porous Media. ORNL-5601, Oak Ridge National Laboratory, Oak Ridge, TN. pp. 137.

18. A. S. Rogowski and T. Tamura. 1965. Movement of ${ }^{137} \mathrm{Cs}$ by Runoff, Erosion and Infiltration on the Alluvial Captina Silt Loam. Health Physics 11:1333-1340.

19. J. R. McHenry. 1968. Use of Tracer Technique in Soil Erosion Research. Trans. Amer. Sor. Agricultural Engineers 11(5):619-625.

20. J. C. Ritchie and J. R. McHenry. 1977. The Distribution of ${ }^{137} \mathrm{Cs}$ in some Watersheds in the Eastern United States. Health Physics $32: 101-105$.

21. R. B. Brown, N. H. Cutshall and G. F. Kling. 1981. Agricultural Erosion Indicated by ${ }^{137}$ Cs Redistribution: I. Levels and Distribution of ${ }^{137} \mathrm{Cs}$ Activity in Solls. Soll Soc. Amer. Jour. $4(6): 1184-1190$.

22. R. B. Brown, G. F. Kling and N. H. Cutshall. 1981. Agricultural Erosion Indicated by ${ }^{137} \mathrm{Cs}$ Redistribution: II. Estimates of Erosion Rates. So11. Soc. Amer. Jour. 45(6):1191-1197. 


\title{
8. HASTE MANAGEMENT OPERATIONS PROGRAM
}

\author{
J. D. Sease
}

\subsection{INTRODUCTION}

The major function of the Program is to operate the Laboratory's systems and facilities for collecting and disposing of radioactive gaseous, liquid, and solid wastes. This includes the collection and shallow land burial of about $2,000 \mathrm{~m}^{3}$ of beta-gamma contaminated waste and retrievable storage of about $60 \mathrm{~m}^{3}$ of transuranium contaminated waste annually; ionexchange treatment and release to the environment of about $450 \times 10^{3} \mathrm{~m}^{3}$ of slightly contaminated water; volume reduction by evaporation of about $5,000 \mathrm{~m}^{3}$ of intermediate-level liquid waste followed by hydrofracture injection of the concentrate; and scrubbing and/or filtration of the gases from radioactive operations prior to release to the atmosphere. In adition, this year disposal of about $350,000 \mathrm{gal}$ of radioactive sludge from the old (no longer in service) gunite tanks began. Operations are in conformance with rules and regulations presently applicable to ORNL.

Th:.s Program is responsible for planning and for development activities for upgrading the facilities, equipment, and procedures for waste disposal; the objective is to ensure that waste management facilities and procedures at ORNL incorporate the latest technology and are consistent with DOE and other regulatory requirements. Major (line-item) new facilities are provided as well as substantial (GPP) upgrading of old facilities. Technical and engineering support is provided to handle nonroutine operating problems. $\Lambda$ n environmental research and development (R\&D) group 
conducts studies of our shallow land burial operations to identify sitespectfic problems and produce scientific basis for corrective actions -as vell as generic information of use to the National Low-Level Waste Management Program. Also, studies for volume reduction of solid waste for disposal are carried out by R\&D groups supported by the Program. Identification and design and development activities continue for a new disposal area for solid low-level waste generated at ORNL and for a central disposal facility for solid low-level radioactive waste for the three DOE plants located in Oak Ridge. Various operations are under study for disposal of the uranium-contaminated scrap metal currently stockpiled at DOE enrichmen: facilities. Also, work continues to dev'slop operational tools for the DOE traffic managers in the transportation of radioactive materials and hazardous wastes.

\subsection{PROGRESS}

Technical progress for each of the tasks of this program for fiscal year 1982 follows.

8.2.1 Dperational Planning and Development (J. H. Coobs, J. R. Gissel, R. E. Helms, S. H. Merriman, T. F. Lomenick, F. E. Harrington, T. S. Mackey, H. O. Weeren, T. F. Scanlan, T. N. Tiegs, and E. S. Bomar)

This task provides technical and engineering support and coordination services for all of the activities related to the management of solid, 1iquid, and gaseous radioactive wastes generated at ORNL as a result of varlous R\&D and radisisotope production programs. The objective is to ensure that waste management procedures and facllities at ORNL incorporate the latest technology and are consistent with DOE and other regulatory requirements. A further objective of this task is to 1dentify the need for, plan for, and bring into operation new or reno- 
vated facilities for the management of ORNL radioactive wastes. A technical support base to handle nonroutine operating problens and to evaluate and wontor the operating perfornance of the various waste managenent facilities at ORKL is also provided through this activity. Activities include the overall magement and long-range planning for the inprovenent of radioactive waste operations, identification and justification of Improvenent projects, support for conceptual design of IIne-iten and capital projects, preoperational checkout and startup of new facilities prior to turnover to routine operation, and planning for the management of new types of waste that ight arise as the result of new R\&D or production programs. This task is divided into four subtasks as follows: (1) Management and Planning, (2) LIne Iter Project, (3) General Plant Projects (GPP), and (4) Engineering Studies and Developwent.

\subsubsection{Management and Planning}

This subtask supports all activities associated with overall management of the program. An Important function is long-range planning, which is performed through the actions of an ad hoc committee. The new committee appointed in October 1981 consisted of 15 members representing several disciplines and drawn from waste management staff and the staff of waste generating programs. This committee and the five-member working group formed to support the committee were divided into seven subcomittees as follows: Gaseous Radioactive Waste, Liquid Radioactive Haste, Solid Low-Level Radioactive Waste, TRU Waste, Standards and Regulations, Decontamination, and Decommissioning, and Corrective Actions. These subcomnltees wet individualiy to Identify and evaluate 
problen areas and discuss solutions and reported periodically at meetings of the full conmittee. After a series of such meetings, each subconittee had plepared a draft report that described the attributes and shortconings of the various components of waste management systems and listed recomended inprovements to the systems. The working group then used these subconittee reports to prepare a summary report that presents a consolidated and prioritized set of recomendations for practices or projects to improve the systems. This report also presents estimates of cost to implement the recommendations. The draft summary report was completed and submitted for review and concurrence by management. After revision to accommodate comments and corrections, the report w11 be issued in FY 1983 as Phase I of the long-range planning activity, to support and guide the preparation of waste management plans that are updated annually. The several subcommittee reports will be issued as a consolidated report that will serve as a source and reference document for planning activities.

Another important function is the coordination of Independent assessments of waste management criteria and practices. During FY 1982, a work package was Identified for the development of generic assessment criteria for the evaluation of DOE solid waste disposal operations relative to commerclal practices and standards. Th1s work package was submitted for competitive bids and was awarded to Dames and Moore. The scope of work also Includes use of the generlc criterla to assess waste management practices at ORNL and to develop a program plan for assessing each of the other DOE sites administered by Oak Ridge Operations. Dames and Moore submitted a draft rort on generic assessment criteria and guidelines; comments and suggested revisions from our review were 
resolved in a conference at the end of September, and the final criteria document is belng printed. Dames and Moore is using these criterla to proce 1 with their assessuent of ORNL's solld waste magement operations.

\subsubsection{Line-iten Capital Projects}

8.2.1.2.1 Nev Hydrofracture Facility. Construction of this faci11ty was coapleted early In FY 1982. The facility was dedicated at a cerewony on October 28, 1982, and preoperational testing and a test Injection were completed in March 1982. Pigure 8.1 shows the facility as viewed from the north side. Detalls of operation beginning with the ILW Injection in June 1982 are s-ven in Sect. 8.2.2 and information on system modifications is given in Sect. 8.2.1.4.

\subsection{Radioact Ive Waste Facilities Improvements Project(8).}

The Radioactive Waste Facilities Improvements Project, ORNL 81T-104, will provide new facilities, equipment replacement, and other improvements to the Waste Management System at the Laboratory. The project will provide replacement and upgrading of off-gas and cell ventilation exhaust ducts ind related equipment at the main stack; a new building with state-of-the-art electronfcs and control computer to modernize the Waste Operations Control Center; and new flow measuring devices and support facilities to upgrade monitoring stations located at White 0ak Creek, Melton Branch, and White Oak Dam. In addition, the scope of the project was expanded to Include upgrading of the 18otope area local. cell ventilation and hot off-gas systems. 


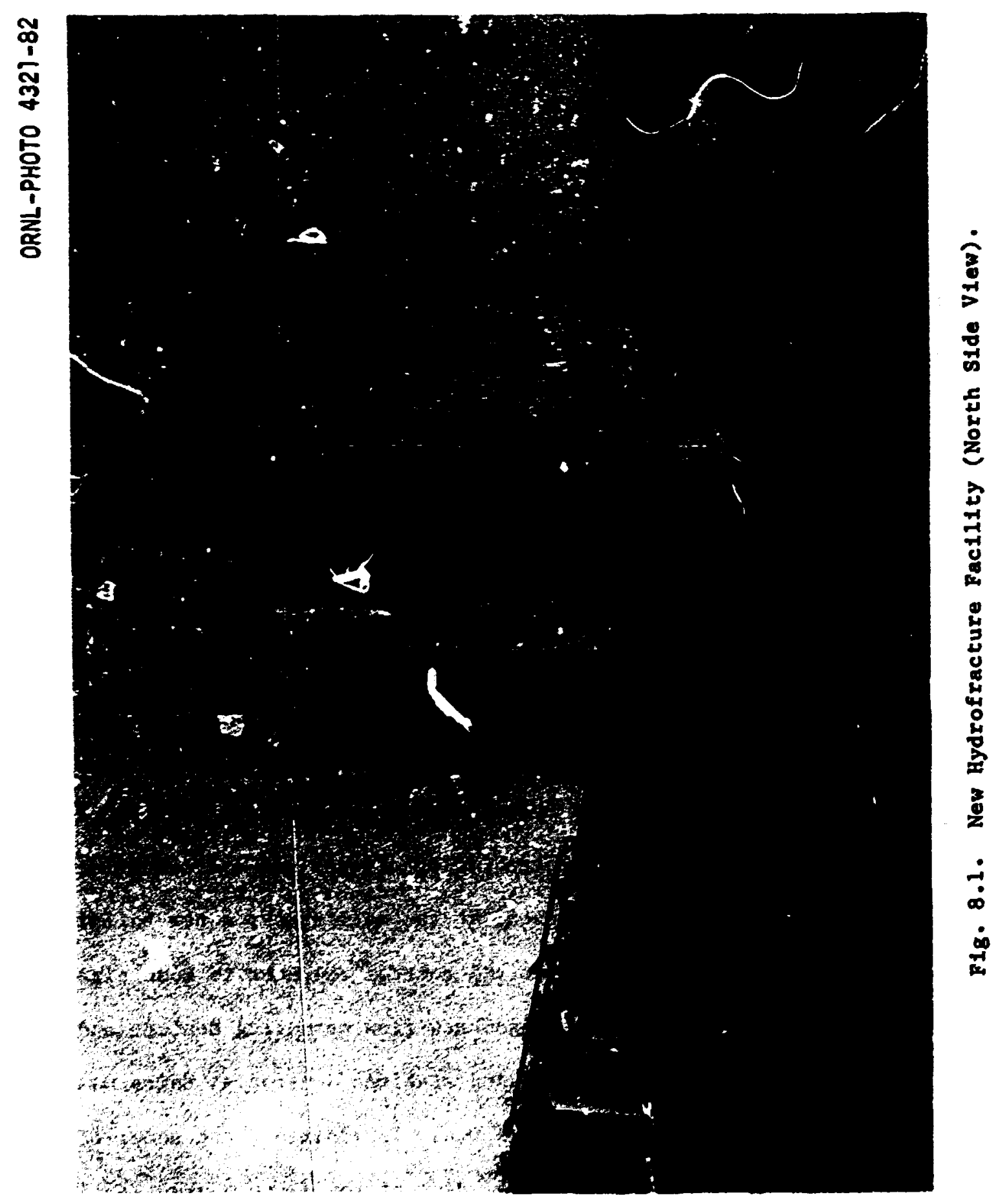


Waste Operations Control Center. In response to the requiremenis for inproved monitoring and control of radioactive waste effluents, ORNL's Waste Managenent Systea is being upgraded. The present Waste Operations Control Center in B1dg. 3105 is being replaced with a new building located on Hillside Avenue. The new factlity (Bldg • 3130), completed in Septenber of 1982, w11 house the computerized dita acquisition systee for real-tine assessment of waste effluent conditions at ORNL. In May 1982, the CADRE Corporation of Atlanta was awarded the contract for a turnkey data acquisition system (DAS) costing $\$ 611,000$. The system includes a host computer, seven remote data concentrator microcomputers, field input interfacing equipment, and systems and applications software. The DAS will collect and analyze over 250 field input signals, trend and display these data, and provide the capability for predicting conditions based on historical profiles. CADRE Corporation has entered into subcontract agreements with other firws for supplying parts of the DAS. All computer equipment and systems software have been purchased from Digital Equipment Corporation, data concentrator housings are currently belng bullt by an Atlanta firm, and front-end field signal interfacing modules are being acquired from Tennelec Corporation. CADRE 18 in the process of developing the applicat lons and communications software. The projected delivery date for the system 1s March 1983. 
Off-Gas and Cell Ventilation Inprovements at Main Stack. Inprovements to the 3039 Stack Off-Gas and Cell Ventilation Systen are to be accomplished in five packages that include: (1) demolition of the old precipitator, (2) buflding a temporary bypass system, (3) demolition of the old duct and improvenents on the scrubber system, (4) bullding a new cell ventilation system, and (5) removal of the temporary bypass system. The first package has been completed.

Construction of the temporary bypass system is underway by Rust Engineering. This system will be installed to provide ventilation during the demolition of the old duct and the bullding of the new 3039 Stack Cell Ventilation System. The temporary system includes two loops with fans $A-B$ and $C$. The ducts for the temporary system have been fabricated and are on site. Most of the ducts for fan A-B that serves the Isotope and $3025 / 3026$ areas have been erected (F1g. 8.2). The temporary fan unit A-B has been set in place as shown in Fig. 8.3. Temporary fan C is also in place.

Upgrading of the off-gas scrubber system, demolition of the old duct, Installation of underground piping, and tie-in connections of systems will also be done by Rust Engineering. Modifications to the scrubber (BIdg - 3092) have been completed. The routing of the new steam and afr supply lines across Central Avenue has been completed. Pabrication of the new stear control station was started. Procurement of the scrubber, pumps, valves, and other equipment and material is on 8 chedule. 


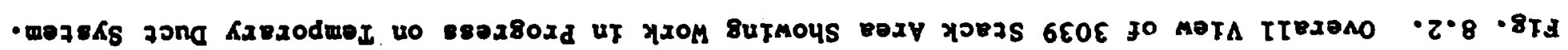

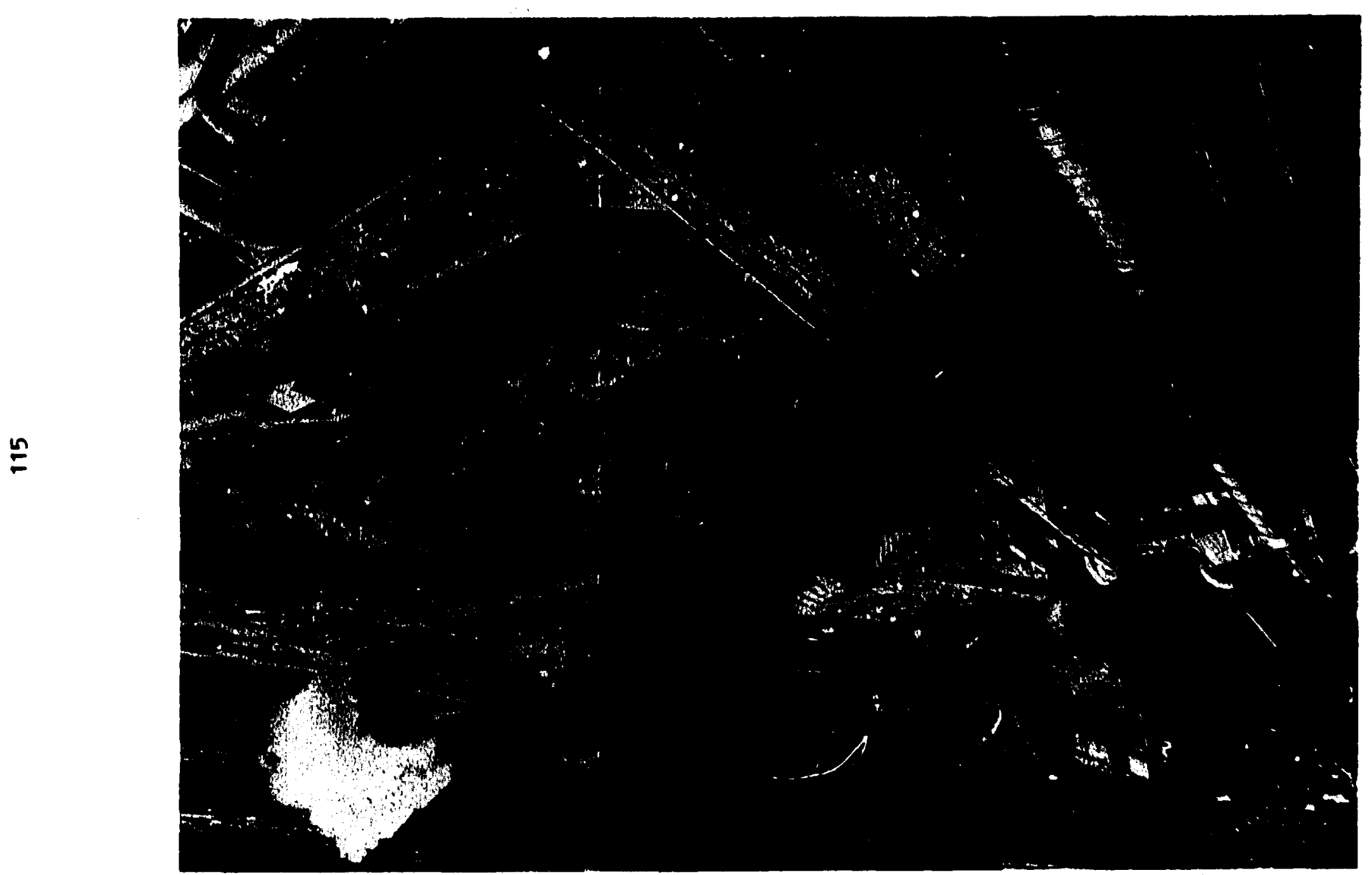

Z8-๕ZEЬ OLOHd-7NYO 
ORNL-PHOTO 4189-82

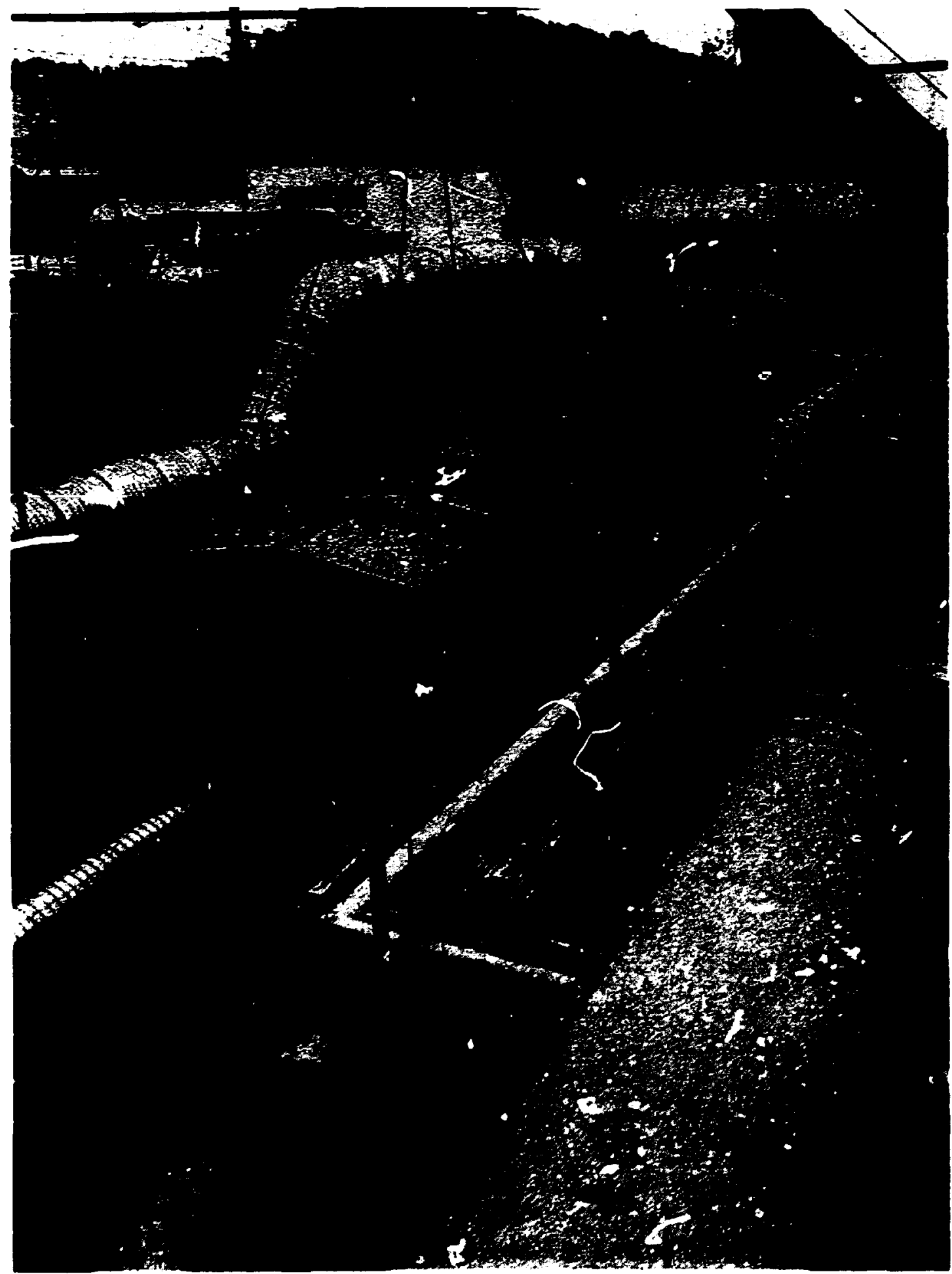

P1g. 8.3. Placement of A-B Fan Un1t for Temporary Duct System. The 3039 stack 18 barely nut of view on the right and the ORR (Bullding 3042) is visible north of the stack area at the extreme left. 
The contract for the new 3039 stack cell ventilation duct $8:-3 t e n$ has been awarded and the FPPC contractor (R. F. Knox Conpany) given notice to proceed.

Stean Flow Konttoring. The SFI task Includes a new nonitoring statIon Ho. 3 at White Oak Creek, a new nonitoring station Ho. 4 on Helton Branch, and a new nonftoring station No. 5 at White Oak Dan. Construction at all three statiuns is a ix of CPAP and PPPC contracts. Rust Engineering w111 do the CPAP portion and Vega Corporation will do the FPPC parts.

The ajor portion of the construction is complete at station Ho. 3, as shown In F1g - 8.4. The bridge construction over the weir, the Installation of instrumentation, and cutting in the strean channel remaln to be completed. At station Ho. 4, the EPPC contractor has completed excavation of the new welr channel. At station No. 5, the PPPC contractor has completed the concrete bridge supports for the new road and has started Installations of forms for the remainder of the channel on the doynstream side of the road, as shown in P1g.8.5. Isotope Area Cell Ventilation and off-Gas Improvements. In August of 1982 , the scope of this project was expanded to include upgrading of the lootope area cell ventilation and hot off-gas systems. This task w111 provide a new, above-ground stack exhaust atainless steel cell ventilation service to existing cells in eight bulldings in the Isotope Area. Also, a new local exhaust will provide bullding containment and hood exhaust to seven bulldings in the Isotope Area. Bxieting underground ducts will be sealed and abandoned in place.

Design criteria were completed and submitted for DOR review in September 1982. Detalled design to scheduled to begin early in CY 1983. 


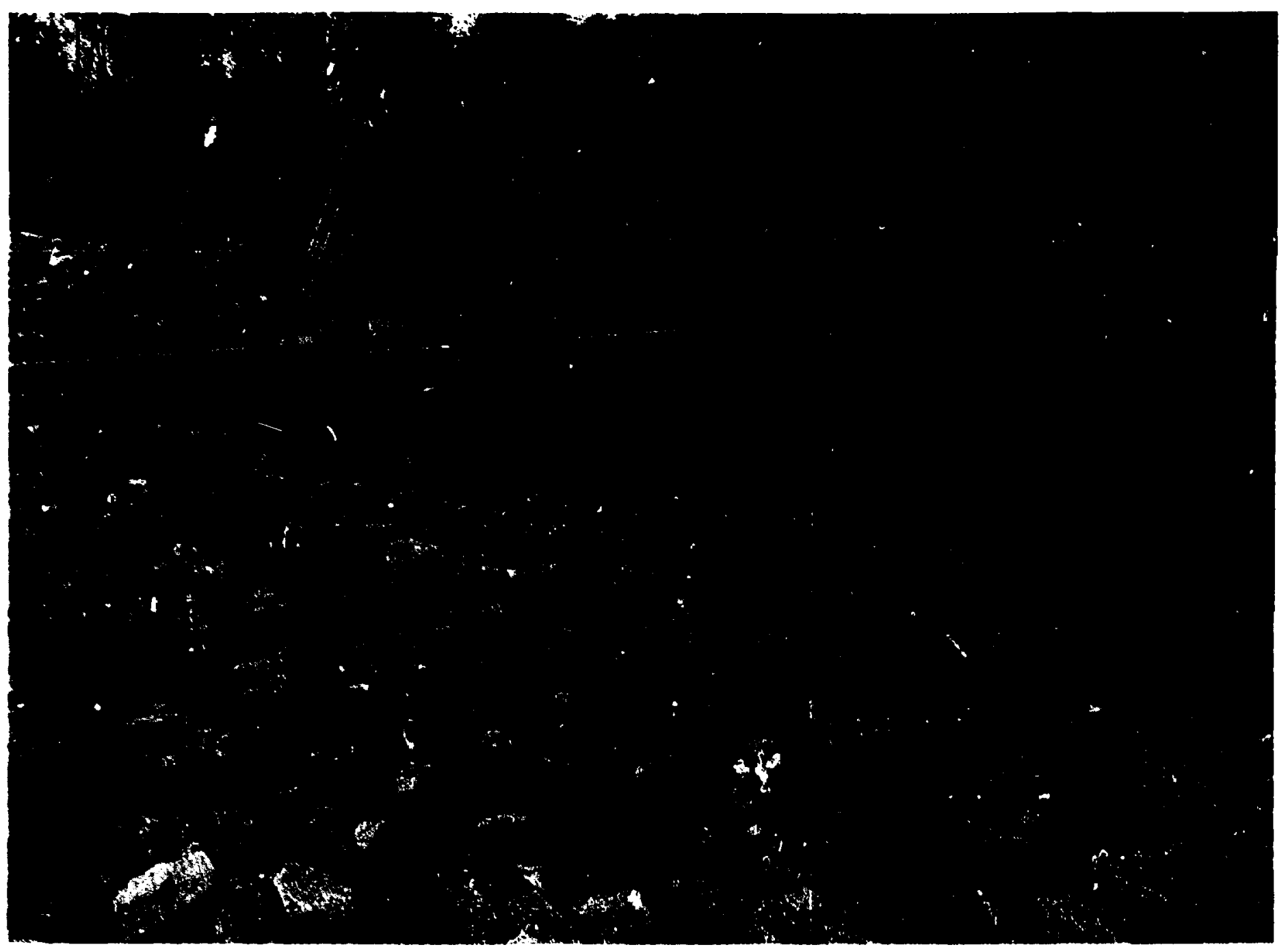

F1g. 8.4. New Monitoring Welr (Station 3), White Oak Creek, From Upper Stream Side. 


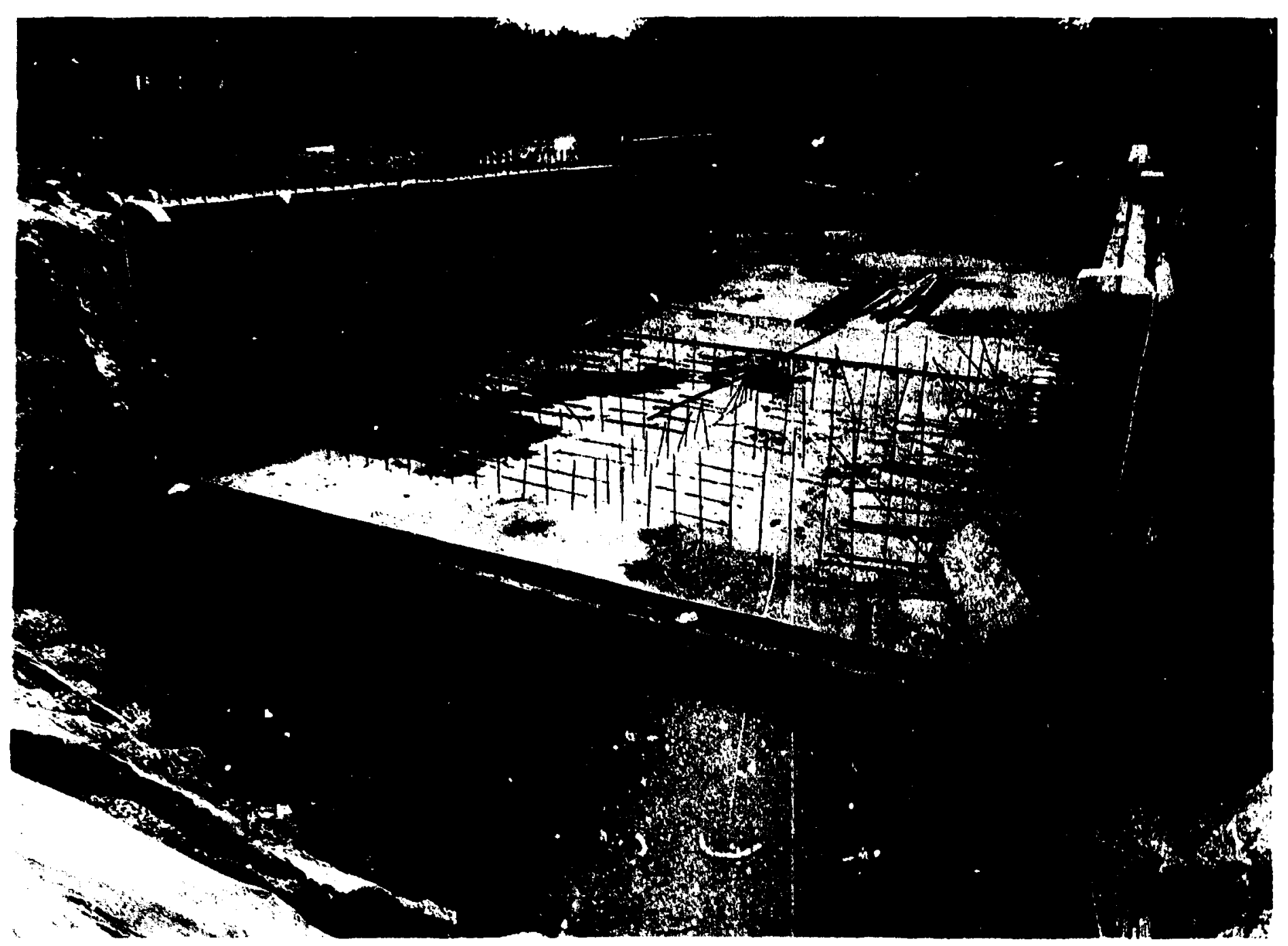

F18. 8.5. Construction of Channel, New Monftoring Welr, Station 5 at White Oak Dam. 


\subsubsection{General Plant Projects}

This activity funds the preparation of conceptual designs, formal engineering designs for and inspections of construction; safety assessments; quality assurance assessments; quality assuranie plans when required; environmental assessments and sinflar documentations that are required for DOE and/or Laboratory approval for directive and suidirective construction projects related to the managenent of radioactive wastes at ORNL. The projects are followed through design and construction, and the preoperational testing and startup are carried out under this activity before the facilities are turned over for routine operation.

8.2.1.3.1 Plezometer Wells, SWSA 5. Five clusters of wells have been drilled and cased In SWSA 5 to permit study of three dimensional flow characteristics of groundwater in bed rock. We11s of 100-, 150-, and 200-ft depths are common to all clusters. All but the first cluster (that installed by Jack Terry Drilling Company, Sevierville, IN) have a fourth well to groundwater. The wells have been made avallable to USGS personnel.

All contractural work assoclated with the project is complete and the project is closed.

8.2.1.3.2 Mag-Card Entry Gate, SWSA 6. SWSA 6 is enclosed by a security-type chain-link fence; the gate, whlch is near public highway Tennessee 95, 18 locked on all off-shift hours. However, the gate is open (unattended) during normal working hours to accommodate many trips 
in and out by operating personnel. As it is not feasible to an the entrance, a magnetic-card entrance control systen was installed by Rust Engineering. The project is complete. Access is avallable, via plastic card and/or key, to those groups of the Laboratory requiring adnission for official rusiness.

8.2.1.3.3 Monitoring Weir, Northwest Tributary (White Oak Creek). This station is to provide quantitative data on activity migrating fron SUSA 3 and the Enviromental Sciences Complex, Area 1500, to White Oak Creek. It was constructed at the recomendation of the Environnental Management Coordinator as a part of the overall program to increase monitoring capabilities at the Laboratory. Rust Engineering has completed field work on schedule and within allotted funds. Fig. 8.6 shows weir and instrument house. 8.2.1.3.4 Fencing, SWSA 3. The western half of the existing fence encompassing SWSA 3 was replaced as it was beyond economical repair. Approximately 1100 linear feet of fencing were replaced and the assoclated land surface contouring restored as required. The project was completed within authorized funding.

\subsection{Groundwater Monttoring Wells In SWSA Areas (SWSA 5 - TRU}

Area). USGS personnel working in the ORNL site have Included these water table observation wells in their schedule now that all work under this project is completa. Locations for the wells were selected by the USGS geologist. Depths vary from well to well. All but one are less than $50 \mathrm{ft}$ deep; it was cored and is $100 \mathrm{ft}$ deep. 
ORNL-PHOTO 4324-82

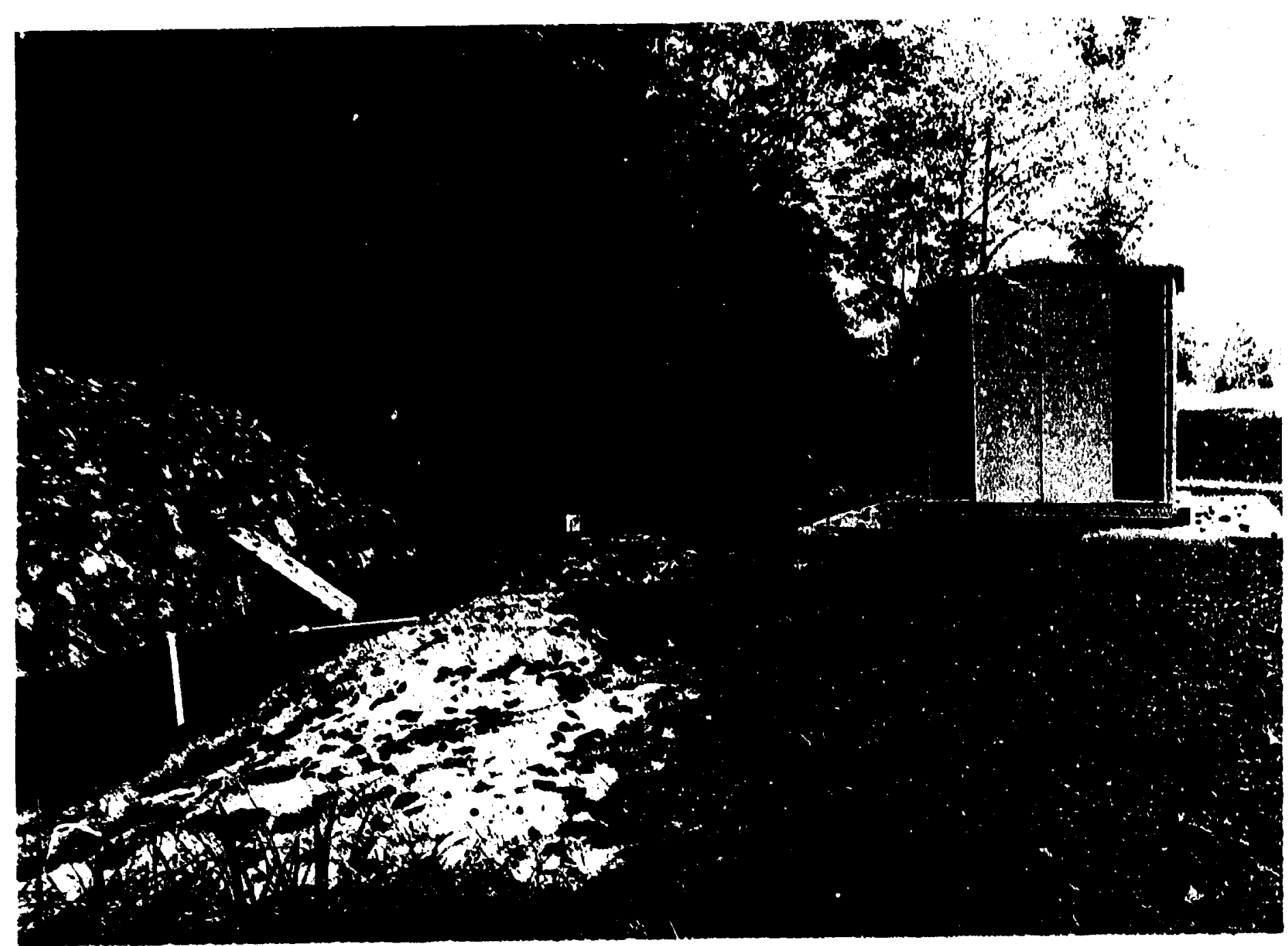

Fig. 8.6. Monitoring We1r, Northwest Tributary. 


\subsection{Decontamination Facllity Alterations (Electropolisher). By} means of this new facility, ORNL has greatly improved its capabilities of decontaminating and returning to use small metallic equipment items, apparatus, and tools. The project required extensive remodeling of the chemical process mixing station area within the Fission Products Development Laboratory (FPDL), Bldg - 3517. Rust Engineering and ORNL personnel worked to remove and/or relocate existing equipment, provide temporary facilities, install new equipnent, and remove the temporary equipment once the new equipment was operable. Except for miscellaneous Items, the project is complete. These minor deficiencies are being addressed and will be completed in time for the directive to be closed within the mflestone completion date, first quarter of FY 1983. Profect schedule was extended twice: the first time from October 1981 to October 1982, and the.r to the end of October 1982. Work stoppages by craft personnel necessitated the first extension; the addition of a women's change room dictated the second extension. The project costs are within those authorized.

8.2.1.3.7 Contaminated 011 Storage Facility. This task provides for a one-story addition to the Waste Storage Tanks, BIdg. 7830 , to house a 5000-gal storage tank and transfer pump. The tank provides capabilities for storing low-level contaminated waste ofl from JRNL Operations while awaiting disposal by injection with ILW waste in the New Hydrof racture 
Facility. In the past, it was the practice to dispose of this ofl by absorbing it on vermiculite and burying it in carbon steel drums. This is no longer acceptable under current guidelines and regulations for effluents. Cousins Construction Company, Oak Ridge, TN, was avarded the contract for this $\$ 330,000$ project; ground was broken in September 1982 , and work is progressing satisfactorily. Field vork is estimated to be 127 complete. All major procurement items are on the site. 8.2.1.3.8 Deconstration Module - Concrete Vaults. This demonstration system is based on concrete boxes ( 27 total) filled with selected solid waste, fmmobllized in grout, and belng stacked in three layers on a concrete pad in SWSA 6 . The array will be earth covered to establish a radiation shield and weather barrier. Figure 8.7 shows schematic view of the project. Since one year is allocated for filling the modules with waste as it is generated, the end of the fourth quarter of FY 1984 was established as the project completion date. Southern Cast Stone, Knoxville, $\mathrm{TN}$, is constructing the symmetrical concrete steel reinforced boxes to ORNL engineering performance spectfications. Work is $50 \%$ complete and progressing :3atisfactorily.

\subsection{Waste Treatment Plant Modifications (Additions to PWTP). The} flowsheet of the plant was rodified to halt the generation of sludge.

The project consists of the procurement and installation of a fourth fixed-bed ion exchange column and miscellanenus ancillary equipment, and changing resin in all columns. The fourth colimn will be simliar to the three existing ones.

An existing settling pond, Incated in Burial Ground 5, was :or.3tructed about ten years ago to provide for the retention of low-level 


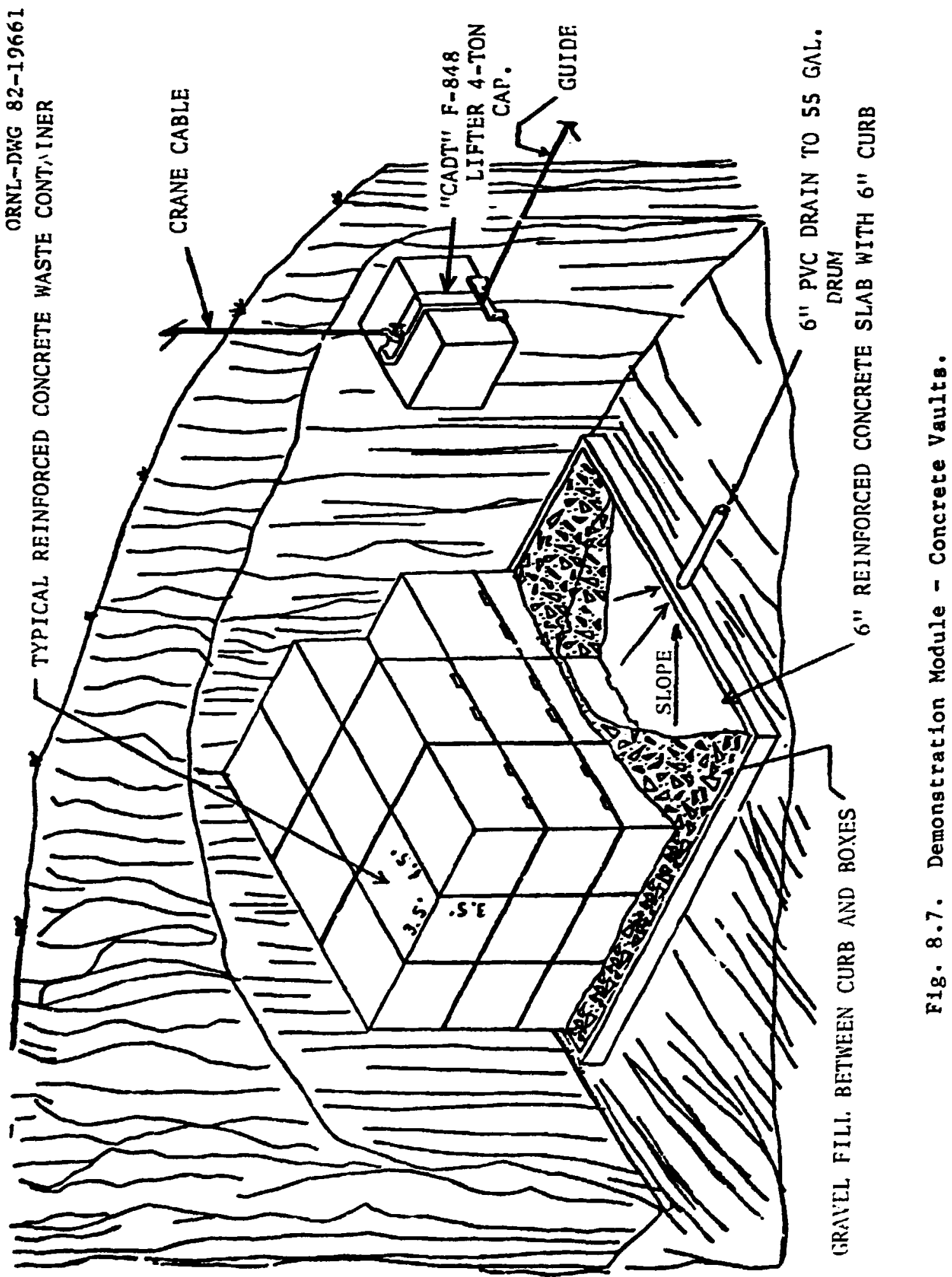


radioactive sludge renoved fron chenical waste streans fron various laboratory operations. At that tine, it was estinated that the storage capactity of the pond would be adequate for 30 years' use. However, current enviromental regulations preclude continued use of the pond for sludge storage. The problen of sludge production wil be elfainated by discontinuing the existing precipitation/clarification proces8, which produces the sludge. The addition of the fourth fired-bed lon exchange colunn w11 Increase the capacity of the Ion exchange process sufficiently to handle the liquid discharge from the laboratories and treat the waste to enviromentally acceptable levels for discharge to white Oak Creek. Rust Englneering Company is the contractor for this project. Much field work has been satisfactorily completed as scheduled; however, considerable difficulties have been encountered in the fabrication, by a vendor under contract to Rust, of the Ion exchange column that is to expand the capabilities of this plant. The column as initially bullt not only falled the corrosion test but was found to have been fabricated partly of Type 304 stainless steel in lieu of Type 304L. It is anticipated that the column will pass inspection in early November, at which time all corrections are scheduled to be complete. The project stands 387 complete. The milestone completion date of fourth quarter FY 1983 should be met, and funds expendec will be rithin the $\$ 300,000$ authorized for the project. Figure 8.8 shows three columns in the southwest room of the building. The fourth column will be added a line. 8.2.1.3.10 Upgrading Bullding 7824 (TRU Waste Assay Demonstration). The ORNL TRU Waste Drum Assay Pacllity (TRU-WDAP) is located in an existing structure, B10g. 7824, which was upgraded to meet program needs. 

The purpose of this facility is to field test, callbrate, and evaluate a detector systen for IRU waste materials which was developed by Los Alanos Natfonal Laboratory (LAN). The detector systen assays TRU wastes without breaching the containment provided by the steel storage druns. The work of codifying and upgrading B1dg. 7824 is complete and the directive closed. Figure 8.9 shows the entrance to the factlity. I neutron interrogation drum assay systen (Fig- 8.10) and gama drum assay systen (PIg- 8.11) with assoclated instrunentation have been installed, callbrated, and checked out. Additional inforwation on the equipment performance can be found under Sect. 10.2 .2 of this report. 8.2.1.3.11 Nev Hydrofracture Facility (MHP) Site Improvements. This project consists of inprovenents to the surface area Imediately surrounding the New Bydrofracture Pacility. Included is surface water run-off control, parking, and asphaltic concrete drives. Inaswuch as this facility is of interest worldwide, these improvements could also be considered necessary for aesthetic as well as for operational reasons. Becalise of the wonthly infection schedule, close coordination Is required between operating and contractor personnel. Renfro Construction Company, Knoxville, TN, is the contractor; work 18 scheduled to begin Immediately after the October Injection.

\subsection{Upgrade Melton Valley Malntenance Bullding. Th1s project} calls for fmproving the prefabricated steel bullding acquired from construction; it had served as the contractor's maln shop during the construction of the New Hydrofracture Pacility. ORNL will ut111ze the unft as a malntenance bullding. Improvements include an adequate heating and ventilation system for energy conservation, better 11ghting, 
ORNL -PHOTO 3029-82

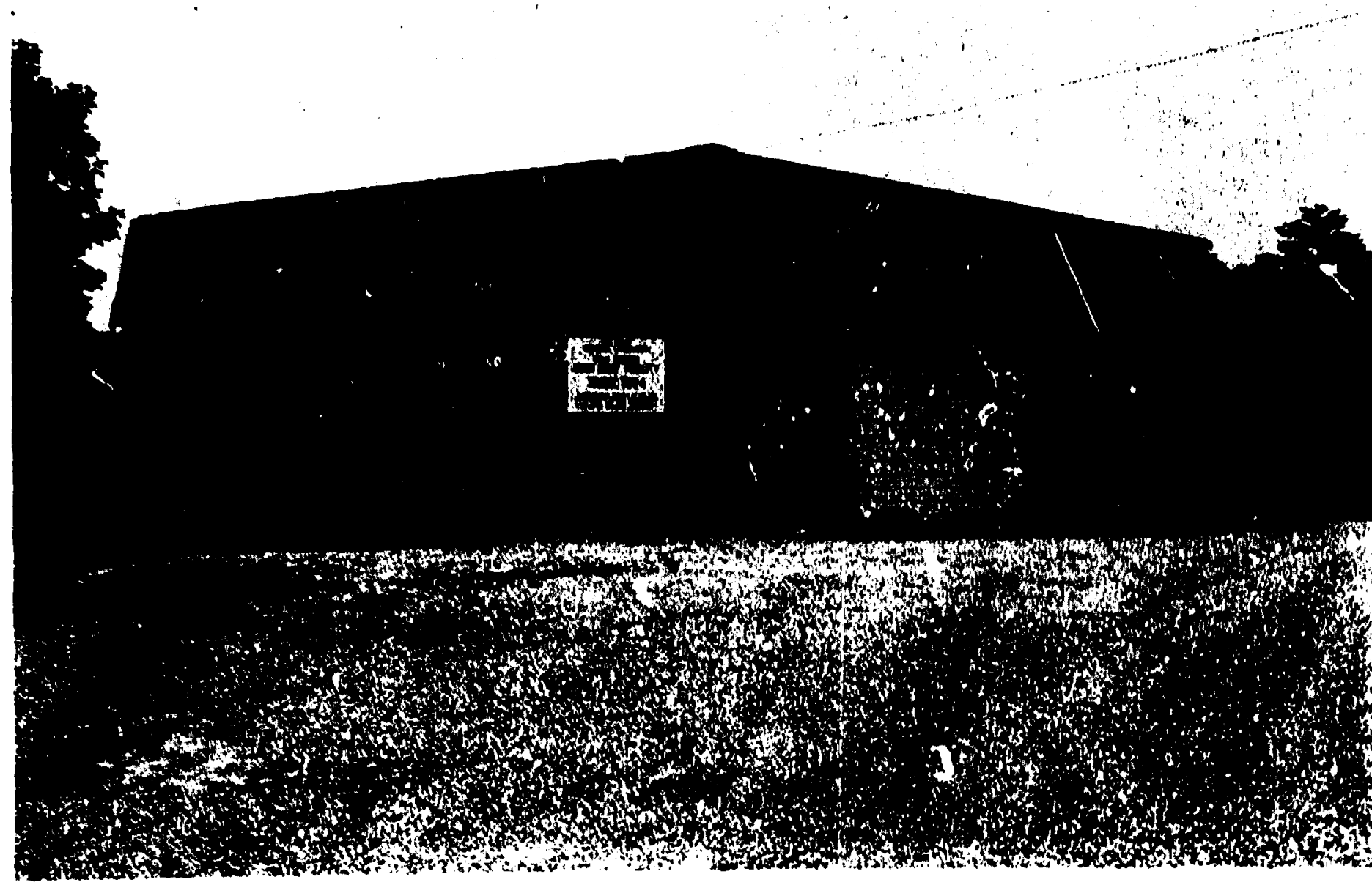

Fig. 8.9. Entrance of TRU Waste Drum Assay Facility. 
ORNL-PHOTO $\quad$ 1522-82

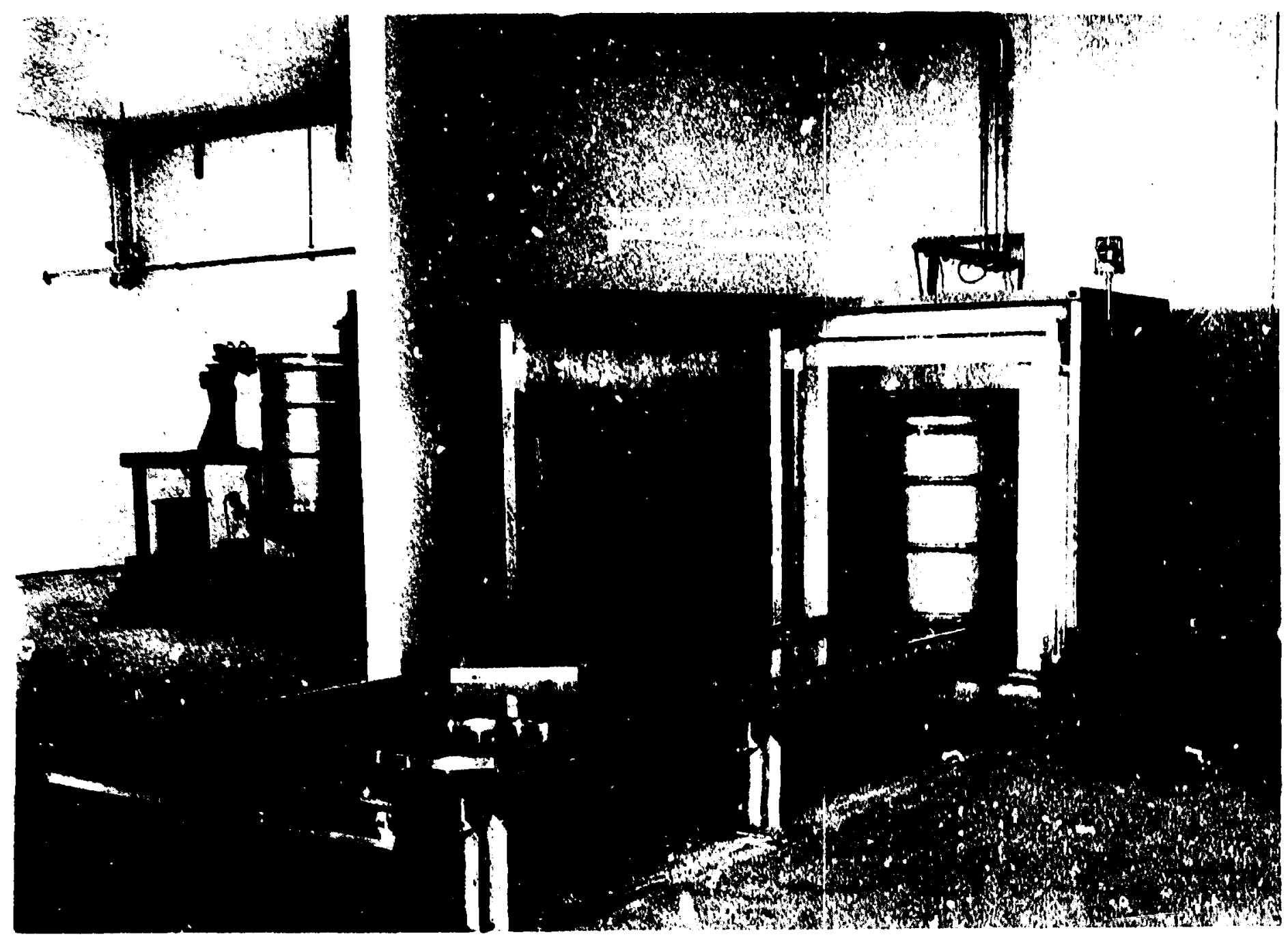

Fig. 8.10. Neutron Interrogation Drum Assay System. 


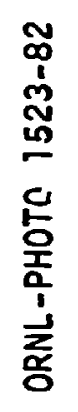

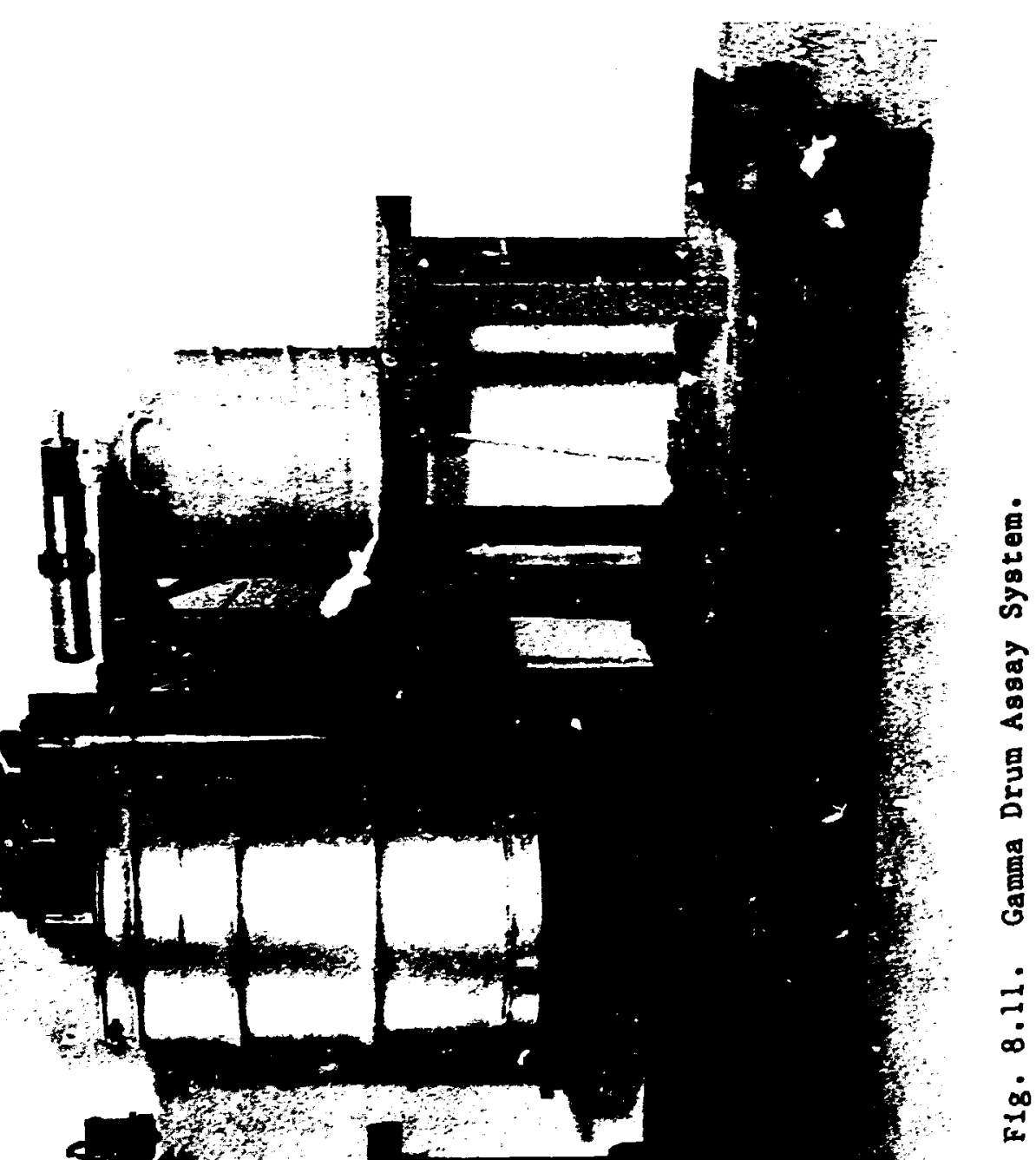


storage area for tools, equipment and work materials, general woià area, and a decontamination room for use with equipment from the NHF, wainly pump parts. Design is complete and is being estimated for construction. 8.2.1.3.13 Core Storage Bullding. A single story prefabricated wetal bullding with $12 \mathrm{ft}$ eave height was erected on a 75- by 85-ft concrete pad east of ORNL's 7000 area by the K. B. Ryedy Constructing Corporation, Oak Ridge, TN. The facility is for storing earth cores from the many sites in the vicinity of the Laboratory. Work is 997 complete and final costs will be within those approved. ORuL has taken beneficial occupancy and has arranged for transfer of cores from rented storage facilities. The scheduled completion date, Noveaber 30, 1982 , will be met. It Is anticipated that the official identity of the facilIty will eventual!y become Centralized Core Storage Facility - Oak Ridge Reservation.

\subsection{Study and Estimates for Future GPP Projects. Engineering} studies and estimates have been expense funded for:

1. Corrective Action, SWSA 4,

2. Deep Monitoring Wells (Far-0ut Wells),

3. Engineered Groundwater Barriar, SWSA 6 (to be an expense profect),

4. Upgrade Valving at the Evaporator Facility,

5. Replace ILW LIne Serving Building 3019,

6. Volume Reduction Pacility,

7. Initial Decontamination Pacility,

8. Upgrading Blectrical Substation at TURF,

9. Replace ILW Line Serving Bullding 3517,

10. Englneered Grcundwater Barrier, Trench 7, 
11. Replace BPIR IIH Transfer Line,

12. Sparge Naste Storage Tanks,

13. Sparge HFIR Settling Pond, and

14. Control Vegetation and Erosion at Elght Service Ponds.

\subsubsection{Engineering Studies and Developnent}

8.2.1.4.1 Hydrofracture. Hydrofracture was developed at ORM for the perwanent disposal of locally generated interwediate-level waste (ILW) solutions. In this process, the waste solution is wixed with a blend of cement and other solid additives; the resulting grout is then Injected into a nearly impermeable shale formation at a depth of 700 - to 1000-ft, well below the level at which clrculating gr.sundwater is encountered. During the injection, the grout forms a thin, approximately horizontal, grout sheet up to $1000 \mathrm{ft}$ wide. The grout sets a few hours after completion of the infection and permanentiy fixes the radioactive waste in the shale formation. A process flow diagram is shown In Fig. 8.12; a picture of the hydrofracture injection facility is s hown In Fig. 8.1 (Sect. 8.2.1.2.1).

The hydrofracture factilty was designed for the disposal of ILW solution; the disposal of resuspended gunite tank sludge is a comparatively recent expansion in the scope of this process. Much development work has Indicated that the operating procedure for sludge disposal would be very much the same as for the disposal of ILW solution; the differences in physical properties between s slurry and a solution could be compensated for by using a different solids mix (one with no attapulgite) and a different mix ratio. 
ORNL-DWG 81.18657

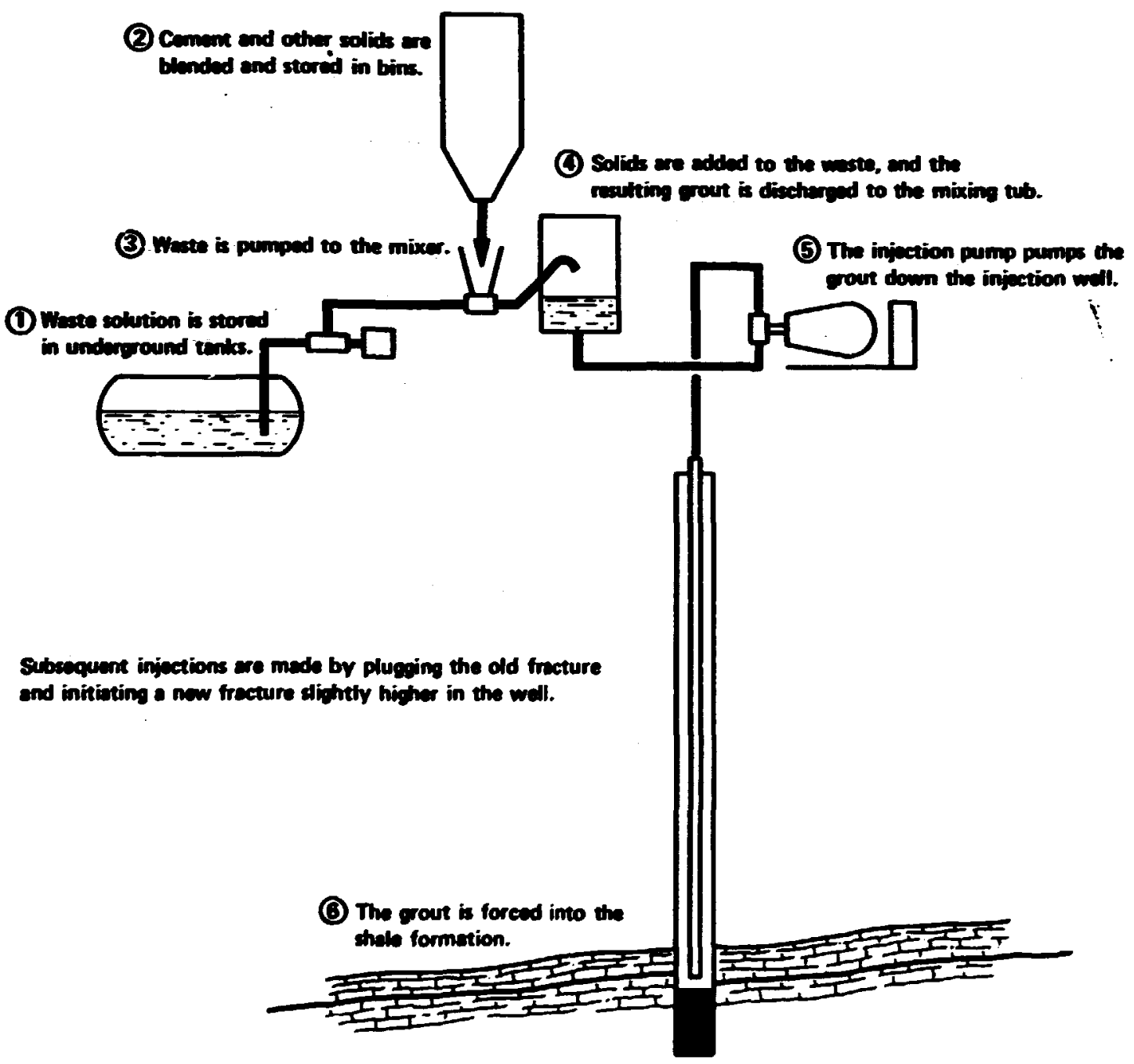

Fig. 8.12. Process Flow Diagram of an Injection Which Requires About $10 \mathrm{~h}$ to Complete. 
Preinjection Activities. The Safety Analysis Report for the Nev Hydrofracture Pacllity was originally subcontracted. The final version received from the subcontractor was inadequate and had to be extensively revised. The revised report (ORI/BNG/INF-81/2) vas lssued with approvals In May 1982.

In conjunction with the Safety Analysis Report, the Operating Safety Requirewents were written and approved. In addition, operating procedures and quality assurance docunents were vritten and approved. Analysis of previous hydrofracture injections indicated that the blending of the set retarder with the other components of the dry aix naterlals was inadequate. Such incomplete blending could resuit in the properties of the blended $\mathrm{mlx}$ varying appreclably and unpredictably. This hypothesis was checked during the cold test injection (Sect. 8.2.2.1) In March and confirmed. Procedures were therefore altered so that future retarder additions would be made to the waste solution Instead of the dry solids.

All observation wells were logged prior to the first injection of waste at the New Hydrofracture Facility and subsequent to each injection at this facility. Observation wells at the shale fracturing fac1lity (retired from service in 1980) were pressure tested and, depending on the response to the pressure test, capped or plugged.

Injections. The firgt operational use of the new facility (1n June 1982 was for the disposal of the ILW solution that had been accumulating since the last injection at the original facility (May 1979). In preparation for the Infection, 525 tons of dry solids were blended and stored. 
The waste solution was sampled, and the appropriate alx rat1o was deterIned. During the Injection, a total of about $160,000 \mathrm{gal}$ of waste solution was wixed with the solids blend and injected during a 2-day operation. This waste solution contalned about $15,000 \mathrm{CI}$ of ${ }^{137} \mathrm{Cs}$, $140 \mathrm{CI}$ of ${ }^{90} \mathrm{Sr}$, and $2.6 \mathrm{Cl}$ of long-11ved TRU 18otopes. The flow of solids was swooth and unifore throughout wot of the infection; consequently, excellent control of mix ratlo was maintained. The measured radiation levels outside the process cells were equal to or less than background; the levels Inside the cells, deternined after washup had been conpleted, were also generally low. Logs of the observation wells Indicate that the major wovenent of the grout sheet was to the north and west. Logs of the observation wells at the old fracturing facility Indicated that no grout sheets traveled that far.

A few difficulties were encountered. The injection pump rattied and bumped at high flow rates, presumably because of incomplete deaeration of the grout. In addition, the mixer hopper occastonally plugged and had to be cleared.

The first operational sludge infection in the new factilty was made in August 1982. In this injection, 180,000 $\mathrm{gal}$ of resuspended sludge was mixed with a dry solids blend and infected. The injected waste contained about $37,000 \mathrm{Cl}$ of ${ }^{90} \mathrm{Sr}, 6,800 \mathrm{Cl}$ of ${ }^{137} \mathrm{Cs}, 800 \mathrm{Cl}$ of ${ }^{244} \mathrm{Cm}$, and $93 \mathrm{Cl}$ of long-11ved TRU 18otopes. The infection was successfully completed, but considerable operating difficulties were experienced. The major problem was caused by an irregularity of solids flow in the mixer hopper. (Th1s irregularity had been observed during the previous ILW injection but had caused few problems.) During the infection, 
the solids would periodically bridge, i partially bridge, in the hopper. Such situations would require the injection to be halted, the Ex tub and the piping maifold to be washed, and the hopper to be cleared. Each interruption lasted several hours. A secondary problea arose from the tendency of grouts containing bentonite to gel (form a jelly-11ke ass) unless kept in constant wotion. As a result, infrequently used lines tended to plug unless washed. In addition, gelled grout tended to accumulate in stagnant areas of the mix tub. These accumulations reduced the effective tub volune and led to control probleas; they were also quite difficult to wash from the tub during shutdowns.

Several equipment modifications were made prior to the second sludge infection (made in September 1982). These include the following: (1) the screen was removed from the mix tub and the tub was cleaned, (2) the mix hopper wis cleaned and a conical flow disrupter was installed in the mix hopper to improve solids flow, (3) the injection pump was repacked, and (4) a new mix jet nozzle assembly was installed (the old nozzle was found to be eroded).

The infial injection pressure for this injection was unexpectedly high $(8,500$ psi), but this pressure decreased below 4,000 psi within about an hour. About $120,000 \mathrm{gal}$ of waste slurry was infected; this

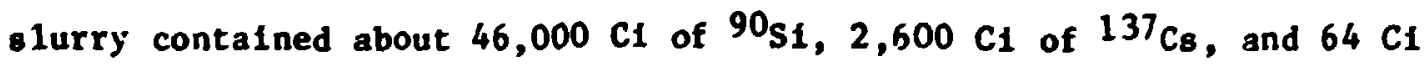
of long-1ived TRU isotopes. No ${ }^{244} \mathrm{Cm}$ was reported. The injection ran exceedingly well. The flow of solids was smooth and even throughout the injection and the control of the mix ratio was, in consequence, very good. No bridging of the dry solids in the $\mathrm{mlx}$ hopper was observed and 
the tendency of the grout to gel in the $n$ lx tube was ach less evident. The only difficulties that were noted were a tendency of the infection puap to knock at high flow rates and the unexpectedly high inftial Injection pressures.

Other Technical Support. The state-of-the-art report on hydrofracture that was written for IAEA was completed and forwarded to IAEA for Issuance as a docunent in their safety serles. This report has been Issued as an ORM/CF document for Internal use. Slight modifications were made to the document sent to IAEA, and publication is now pending. 8.2.1.4.2 Solld Waste Storage Area No. 7 (SWSA 7) Development.

A draft long-range plan for improvement of facilities and practices for radioactive waste managenent has been prepared, as mentioned in Sect. 8.2.1.1. The ad hoc committee that prepared the report concluded that the useful life of SWSA 6, the present disposal area for solid lowlevel waste, $18 \mathrm{six}$ to ten years and that a new area must be developed within this period. The committee recommended two courses of action, as follows: (1) develop SWSA 7 to recelve high-activity, low-level solid waste by 1988-1990 and (2) promote development of a central radioactive waste disposal facility for low-activity waste. The development of SWSA 7 is discussed In this section and In Sect. 8.2.5.3, and the design and development support for a central facility 18 presented in Sect. 8.2.8.

Siting of SUSA 7 within the White Oak Creek watershed has several advantages, as follows: (1) It contains all waste burial facilities presently utilized with reasonable success by ORNL, (2) it contains an adequate water quality monitoring system for besin discharge, (3) portions 
of the basin are underlain by formations which are viable as a burial nediua, (4) appreclable hydrologic data are avallable, and (5) the watershed is near to vaste sources.

Of the seven rock units that form the bedrock on the Oak Ridge reservation, two have characteristics which ake then the wost likely cholces as a burial mediun for LLW. These rock units are the Conasauga and Knox Groups, both of which occur within the thite Oak Creek basin. The Conasauga appears preferable because of 1 ts perfornance under the current waste disposal progran on the reservation. The Knox residum, while apparently successful for santary landfills in East Tennessee, has not been sufficientiy investigated to evaluate its potential as a burial mediun for LLW at ORKL.

Four moderately-sized (>20 acres) tracts within the 1375-acre White Oak Creek drainage basin are underlain by the Conasauga and have tentatively been determined to warrant further site characterization studles. Two of these tracts, when considered together, are the leading candidates for these future studies. Site characterization studies are proceeding on these two favored tracts. These txacts already have installed monitoring wells and lie along strikes with the same rock units in which existing disposal facilities are located.

8.2.1.4.3 Volume Reduction Cost Study. Costs for solid low-1evel radioactive waste (LLW) treatment steps and disposal operations were developed for the quantity and type of LLW generated at ORNL. Publication costs are reported for varlous combinations of waste treatment process steps, packaging, and disposal operations based around an existing ORNL faulify. Both operating and capital cost components were 
developed. The capital cost estinates included a capital recovery factory based on capital recovery in 20 years, $10 \%$ annual interest, and levelized payrents.

The overall costs for waste treatment and disposal varied from $\$ 40$ to $\$ 1740$ per $\mathrm{ft}^{3}$ of Intial solid waste volune. The lower costs were for Type I ( $<200 \mathrm{DR})$ rubble waste with ainimum processing and disposal operations and the'higher for Type II (>200 mR) combustible waste with Incineration followed by ash disposal in a concrete box in a concrete vault. The jor cost factor in almost all cases considered was capital costs (which accounted for $>907$ of overall costs in the highest cost option). AIl costs are very sensitive to the ORNL throughputs of the various type wastes.

These estimates may be used to help identify the more economical options available for future volume reduction efforts at ORNL. They should be useful elsewhere in relative, rather than absolute, terms.

B.2.1.4.4 Study and Estimates. Another conclusion of the draft long-range plan mentioned above was that the Intermediate-level liquid waste (ILW) collection system should be doubly contalned. A serles of Study and Estimates (S\&E) have been started to determine how this recommendation is to be met. These S\&Es will be used to obtaln the necessary funds and establish priorities. The first four S\&Es nearing completion cover:

1. Improved operability for the central recelving system in the B1dg. 2531 (ILW Evaporator) area to Include direct access to tanks $\mathrm{C} 1$ and $\mathrm{C} 2$, 
2. Double-contained piping from the vicinity of B1dg. 3019 to the central receiving systen which is already doubly contained,

3. Similar piping from close to B1dg. 3517, and

4. Replacing the segent of HFIR-ILW line not presentiy doubly contained. 


\subsubsection{Liquid and Gaseous Waste Syste Operations (E. M. King, L. C. Lasher, R. I.. Switherman)}

Facilities are operated for the treatment and disposal of radioactive liquids and gaseous wastes generated at ORML. There are separate systems for the collection and treatment of low-level (process) liquid waste and intermediate-level liquid waste (ILW). The low-level waste is treated at the Process Waste Treatment Plant (PWIP) by an Ion exchange process and the cleaned effluent is released. The intermediate-level waste is concentrated by a factor of 20 to 30 in an evaporator. When a sufficient quantity $(-100,000 \mathrm{gal})$ of concentrated waste is collected it is disposed of at the New Hydrofracture Facility (NHF). At the NHF, the concentrated wastes are mixed with cement and other solids to form a grout and are injected under pressure into a shale formation at a depth of about $1,000 \mathrm{ft}$, where the grout solidifies, for final disposal.

The gaseous waste disposal system collects radioactive gases (cell ventilation, vessel off-gas) from various areas of the Laboratory and discharges them to the atmosphere through tall scacks. The gases are filtered through high-effiriency filters or scrubbed before they are discharged. Continuous operation of the facilities for the treatment and disposal of the radioactive liquids and gases is essential to prevent releases to the environment from currently operating facilities and from old facilities that were used in earlfer discontinued AEC and ERDA programs.

The Eastern Filter Test Station, located at Oak RIdge Gaseous Diffusion Plant (ORGDP), makes quality assurance inspections and tests HEPA filters for all DOE installations east of the Mississippi River and, on a cost recovery basis, for other installations. Also, other DOE-requested or -authorized services such as research, development, and laboratory support are provided in the areas of air filtration. 


\subsubsection{Liquid Waste System Operations}

Approximately $452 \times 10^{3} \mathrm{~m}^{3}$ slightly contaminated water were processed through the process (low-level) waste system. The Process Haste Treatment Plant (PWTP) continued operation using the Dowex HCR-WZ (50W-X8) resin that was substitued near the end of FY 1981 for the Duolite resin previously used; this eliminated the head end precipitation step and the subsequent sludge handling procedures. Design was completed and piping changes were made in preparation for the fourth resin column in the PWIP; it is anticipated that the column will be installed and operations will begin in FY 1983.

The intermediate-level liquid waste (ILW) system processed about $5000 \mathrm{~m}^{3}$ of liquid waste through the evaporator facilities. Operations were routine and without incident.

Preoperational testing and calibration of the instrumentation for the New Hydrofracture Facility (NHF) began near the end of FY 1981. A dedication ceremony of the NHF was held on October 28, 1981; the keynote address was given by Dr. G. K. Oertel. Preoperational checks of the instrumentation and individual pieces of equipment continued; and in early February, the solids handling and liquid systems were checked out up to (but not including) the high-pressure pump using about $80,000 \mathrm{Ib}$ of mixed solids (cement, flyash, attapulgite and clay). In March, a cold infection using about 200,000 1b of solids and process water was successfully made; the test was for checkedout/proof of the overall system and training of the operating personnel (including Halliburion) in the new 
facility. As a result of the tests some minor equipment and operating procedure changes were made prior ot the first hot injection. On June 1617, an injection of about $160,000 \mathrm{gal}$ of concentrated ILQ waste and $1,000,000$ Ib of mixed solids was successfully made. During the week of August 9-15 the first injeetion of resuspended gunite tank sludge vas made; this included about $184,000 \mathrm{gal}$ of suspended sludge waste and about $1,050,000 \mathrm{lb}$ of mixed solids. And the week of September 20-24, the second gunite tank sludge waste injection was made - about $120,000 \mathrm{gal}$ of sludge waste and 700,000 lb of mixed solids. Minor equipment and procedure changes marle between injections are described in section 8.2.1.4.1.

The gunfte tank sludge removal facility (GTSR) was certified for operation in early July and sluicing operations began on July 12. Operations have continued since, and as noted above, two injections of resuspended sludge have been made at the NHF. The report for the GTSR facility is given in section 8.2 .4 of this report.

\subsubsection{Gaseous Waste System Operations}

Gaseous waste operations were normal for the year. The average flow through the Building 3039 stack was $63.7 \mathrm{~m}^{3} / \mathrm{s}$; this system provides both process and building ventilation throughout most of the Laboratory. Gaseous waste operations at other stacks at the Laboratory were normal.

Construction work continued throughout the year on upgrading of the ductwork and air handling equipment at the Building 3039 stack. In February, the old electrical precipitator in the vessel off-gas system was removed and buried. At year's end, installation of the duct for the temporary exhaust system was underway; this system w111 provide ventilation to the faclifties during installation of the new permanent system. 


\subsubsection{Eastern Filter Test Station $(\mathrm{K}-25)$}

A total of 3,656 high-efficiency particulate (HEPA) filters were inspected and tested. Of these 211 (5.87) failed to meet specification requirements. One hundred fifty-four of the nonconforming filters contained only minor deviations, not significantly affecting their performance, and these were accepted by the purchasers on deviation approvals. A total of 3,850 high-efficiency face mask canisters and/or cartridges were inspected and tested and only twelve $(0.37)$ were rejected.

The Filter Test Facilities Standards Committee met on October 19-20, 1981, in Golden, Colorado; on February 1-4, 1982, in Hanford, Washington; and on May 24-27, 1982, in Oak Ridge, TN. At the last meeting, drafts of NE Standards F3-42, Operating Policy of DOE Filter Test Faciifties, and F3-43, Quality Assurance Inspection and Test of HEPA Filters, were finalized and submitted for Government/Industry review. 


\subsubsection{Solid Waste Storage Management (J. Bolinsky, T. Grizzard, E. M. King)}

Solid radioactive waste generated at ORNL is disposed of by shallow land burial (beta-gamma waste) or retrievable stcrage (TRU waste) at ORNL; also, very small amounts of off-site waste, as approved by DOE on a caseby-case basis, are disposed of. Disposal is in accordance with approved practices and criteria.

All wastes are segregated and packaged at the point of origin by the generators. Transuranium contaminated (TRU) waste is stored retrievably in stainless steel drums in a I it-type concrete block and reinforced concrete building, in concrete casks in a cave-type building, or (for high beta-ganma TRU waste) in stajnless steel capsules in wells with a shielding-plug closure. The TRU waste is scheduled for eventual transfer to a Federal repository. Beta-gamma (non-TRU) contaminated waste with radiation levels above $200 \mathrm{mr} / \mathrm{hr}$ at the surface of the unshielded container is disposed of nonretrievakly in unlined auger holes. Generally, betagamma contaminated waste with radiation levels $\leq 200 \mathrm{mr} / \mathrm{hr}$ is segregated by the senerator into compactible and noncompactible parts with the noncompactible waste being buried as is, and the compactible portion being compacted into bales (at the burial ground) prior to burial. In addition, in order to conserve trench space, low-nazard (suspect) waste is burfed in landfill in the burfal grounds. 


\subsubsection{Summary of Waste Handled}

The total volume of radioactive waste handled during FY 1982 was $1,941 \mathrm{~m}^{3}$. A breakdown of the disposition of this waste is given in Table 8.1.

Table 8.1. Summary of Waste Handled at ORML Solid Waste Storage Areas for Fiscal Year $1982\left(\mathrm{~m}^{3}\right)$

TRU waste received and stored retrievably

Beta-gamma waste received

Beta-gamma suspect burfed in landfill

Beta-gamma noncompactible received and buried

Beta-gamma compactible received 238

Beta-gamma compactible buried

1,370

279

34

Beta-gamma (compactible and noncompactible) buried

Total waste handled (beta-gamma and TRU)

${ }_{\text {About }} 577 \mathrm{~m}^{3}$ of this were from facility alterations.

\subsubsection{Highlights of Operations}

Efforts to improve appearances at the burial grounds are continuing. All SWSAs were fertilized and low spots were filled and seeded for grass. During the year, Building 7824 was partitioned and sixty percent of the floor space was renovated and modified to accommodate the TRU Waste Assay Station. The remaining floor space in the building contin'sed to be used for SWSA storage.

The new Case backhoe and a JCB endloader have been added to the heavy equipment inventory, replacing old and worn-out machinery. Also, a new Dodge crew-cab pickup replaced the old Ford pickup. 
There was one off-site generated waste shipment received at ORNL during fiscal year 1982 for retrievable storage at SWSA 5 -- a 0.03 a ( $\left.1 \mathrm{ft}^{3}\right)$ container containing a $238 \mathrm{Pu}$ source.

TRU waste storage included ninety-five $0.21 \mathrm{~m}^{3}$ (55 gal) and three $0.11 \mathrm{~m}^{3}$ (30 gal) drums in Building 7834; ten concrete casks and one $0.8 \mathrm{~m}^{3}$ (30 $\mathrm{ft}^{3}$ ) metal box were stored in Building 7855.

Current activities by ESD researchers involving assistance by Operations Division personnel Include the Experimental Trench Facility (ETF - nine trenches filled with compacted waste for evaluating the effectiveness of liners and grouts in retarding radionuclide movement) and the experimental suspect waste landfill trench study (three trenches filled with suspect waste and a grout injected in the trenches to fill voids and to retard radionuclide movement). Operations Division personnel cut, clear, and maintain access roads for various ESD activities.

\subsubsection{Volume Reduction Operations}

The actions begun and intensifled, beginning in early FY 1978, to reduce the volume of solid radioactive waste for disposal have continued. The most effective appear to be: (1) the awzreness program for reducing waste volume, (2) better separation of contaminated from noncomtaminated waste at the point of origin and locking of the radioactive waste collection dumpsters, (3) separation of the low-radiction-level waste Into a compactible (with compaction at the burial ground prior to burial and a non compactible part, and (4) our landf111 operation of low-hazard contaminated waste. These actions will continue along with others including charging the generator for disposal of currently generated waste, emphasis 
on control of materials entering contanination zones, and better packaging to reduce voids and factlitate handling.

Tean audits were made of all facilities generating solfd radioactive wastes to review how well the volume reduction program is working and to discuss associated problems; the teams are made up of representatives from the burial ground operating group, Health Physics, and the group operating the facilfty being inspected. We are receiving excellent cooperation.

We received sizeable amounts of waste this year from construction, renovation, and cleanup jobs; emphasis has been placed on contacts with supervision of these jobs to encourage reduction of the amount of radioactive waste to as low as practical.

The compactor (for compaction of soft waste with a radiation level of $\leq 200 \mathrm{mr} / \mathrm{hr}$ of the unshilded packages) was used to compact about $279 \mathrm{~m}^{3}$ of waste into 81 bales with a volume of $34.5 \mathrm{~m}^{3}$ for a reduction ratio of about 8.1 .

Since October 1977, users of the burial ground have been charged for costs of current disposal operations. Charges include the cost of collection, transportation, compaction, and disposal (burial or retrievable storage) of the waste; and, beginning in FY 1981, costs of environmental monitoring were added to the charges. 
The costs to users experienced to date are

$\begin{array}{lr}\text { FY } 1978 & \$ 272,621 \\ \text { FY } 1979 & 287,283 \\ \text { FY } 1980 & 311,156 \\ \text { FY } 1981 & 513,301 \\ \text { FY 1982 } & 521,204\end{array}$

Hote: All costs to date include an overhead rate of about 317.

Table 8.2 is a sumary of the waste handled from FY 1978 through FY 1982. Our volume reduction efforts were intensified beginning in early FY 1978. 
Table 8.2 Radioactive Waste Handled at ORNL Burlal Ground, FY 1978 through FY 1982 (m³)

\begin{tabular}{|c|c|c|c|c|c|c|c|}
\hline \multirow{2}{*}{$\begin{array}{l}\text { Period } \\
\text { Fiscal } \\
\text { Year }\end{array}$} & \multicolumn{6}{|c|}{ General Beta-Gamma Radloactlve Waste } & \multirow{2}{*}{$\begin{array}{l}\text { TRU Waste } \\
\text { Stored }\end{array}$} \\
\hline & Recelved & $\begin{array}{l}\text { Buried in } \\
\text { Trenches and } \\
\text { Auger Holes }\end{array}$ & Landf 111 & $\begin{array}{c}\text { Compact } \\
\text { As } \\
\text { ReceIved }\end{array}$ & $\begin{array}{l}\frac{\text { ble Waste }}{\text { After }} \\
\text { Compaction }\end{array}$ & $\begin{array}{l}\text { Savings Due } \\
\text { to Landfill } \\
\text { and Compaction }\end{array}$ & \\
\hline 1978 & $2375 a$ & 2255 & 41 & 88 & 10 & 119 & 65 \\
\hline 1979 & $1955^{b}$ & 1517 & 117 & 361 & 39 & 439 & 75 \\
\hline 1980 & $2409 c$ & 1866 & 230 & 353 & 39 & 544 & 55 \\
\hline 1981 & $2003^{d}$ & 1610 & 113 & 318 & 38 & 393 & 62 \\
\hline 1982 & $1886 e$ & 1404 & 238 & 278 & 34 & 482 & 55 \\
\hline
\end{tabular}

${ }^{a}$ of this, $282 \mathrm{~m}^{3}$ are construction waste.

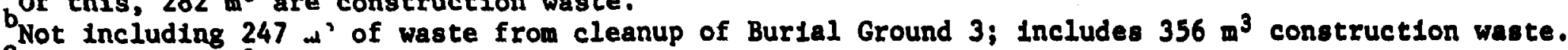

Includes $569 \mathrm{~m}^{3}$ of construction waste.

dincludes $577 \mathrm{~m}^{3}$ of construction waste.

Includes $594 \mathrm{~m}^{3}$ of construction waste. 


\subsubsection{Gunte Tank Sludge Renoval Project (L. D. Bates, H. D. MacNary,} T. N. Tiegs, H. O. Weeren)

The gunite tank sludge removal project (GTSR) provides equipment and facilities for the removal of approximately $350,000 \mathrm{gal}$ of radioactive sludge from six 15 m diam gunite tanks which were constructed and put Into service as a part of the ORNL liquid waste system about 37 years ago. The necessary equipment illustrated in Fig. 8.13 (Dwg. 82-10509) is sequentially installed in each of the tanks as they are cleaned. The sludge removal is accomplished by a circulatory process utilizing tank $W-10$ as a mixing tank. A bentonite suspension is initially prepared in tank W-10 which is then pumped through a jet nozzle in the tank being cleaned. The sluicing action of the jet nozzle discharge entrains sludge in the bentonite suspension producing a radioactive slurry which is then pumped back to the mixing tank $w-10$ after passing through a particle size reduction grinder. Circulation continued until the sludge concentration in the slurry has reached the desired level at which point the sluieing Is stopped and the slurry contents of tank $W-10$ are pumped to the New Hydrofracture Facility for disposal. The process is then repeated until all sludge has been removed.

Facility construction continued from FY 1981. The bentonite mixing system and the work and equipment support platforms over tanks W-10 and W-5 were completed. Necessary 24-in. diam holes in the tops of tanks $W-10$ and $W-5$ were core drilled. Figure 8.14 1llustrates the removal of a core from tank $\mathrm{W}-10$. The core drill is supported by the work platform over the tank. The pump leg, density probe and mixing jet in tank $W-10$, the TV camera, sluicer, and adfustable pump leg in tank $W-5$ were installed. The 
ORNR DWG. 82-10595

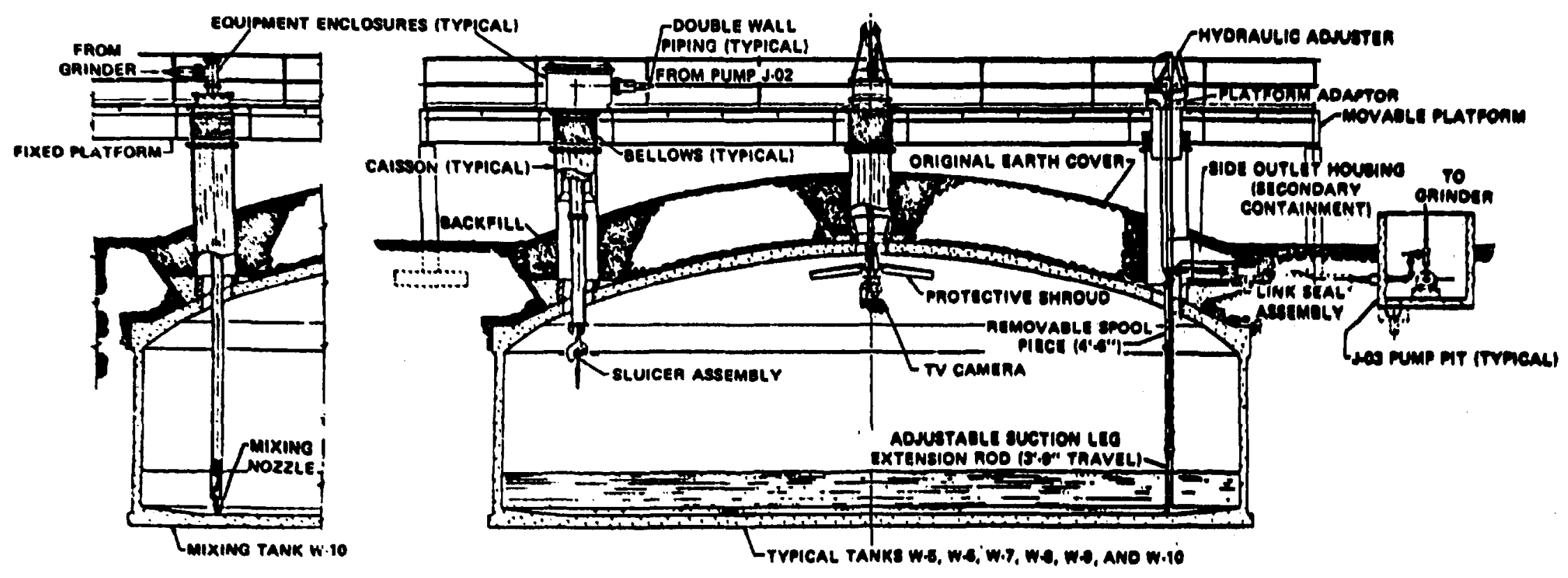

Fig. 8.13 Gunite Tank Sludge Removal Facility Equipment Inatallation. 
ORNL-PHOTO 5786-81

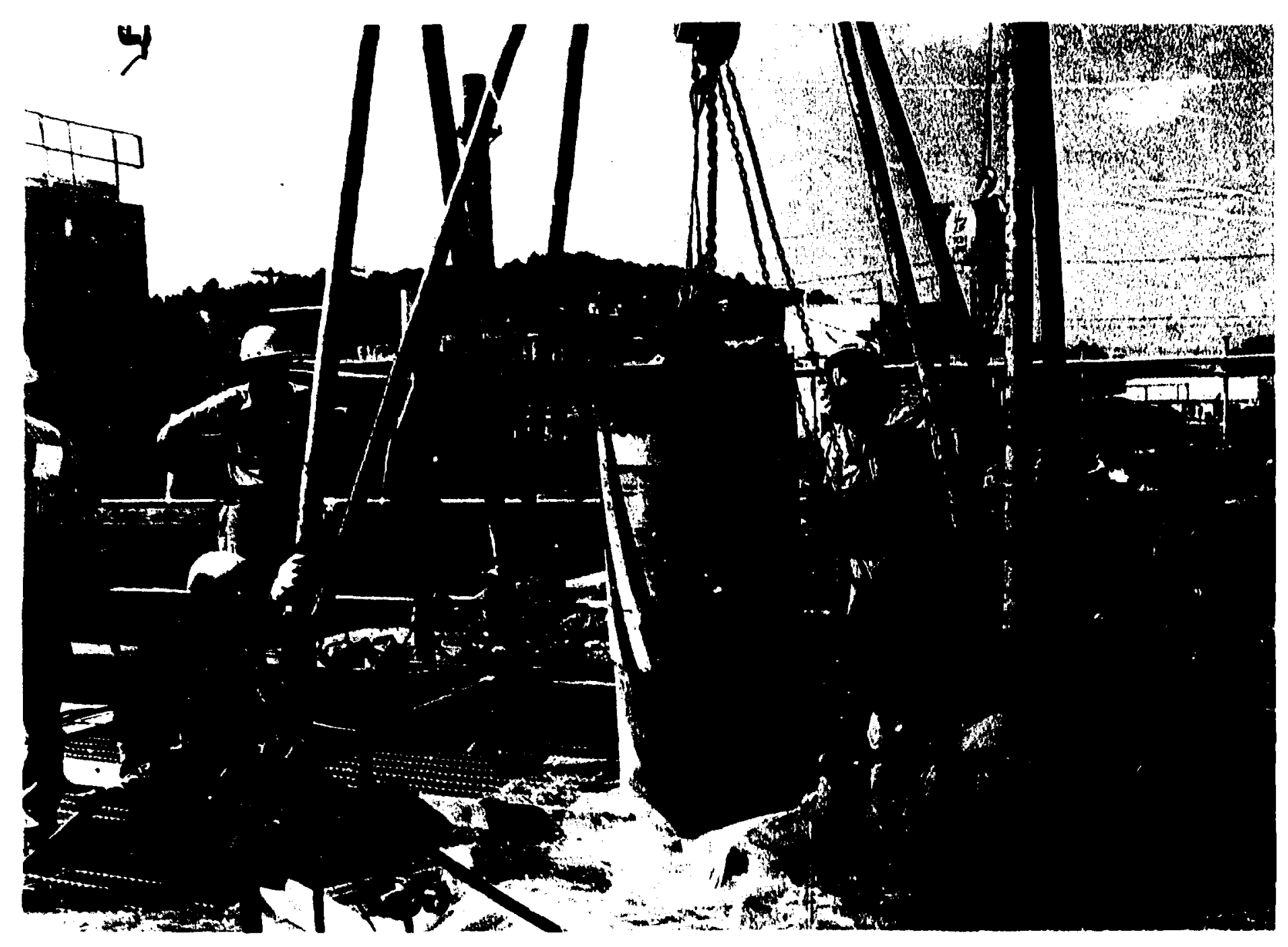

Fig. 8.14 Removal of Access Hole Core from Tank W-10. 
slurry pumps (J-02, J-03) and the grinder were installed and the equipment containment enclosures were completed. Remote controls for the pumps, grinder, TV monitor, and the necessary monitoring instrumentation were installed in the control room (trailer). All site construction activities were completed in December 1981. A critical path study of the project schedule and the interfacing injection operations at the New Hydrofracture Facility resulted in the decision to construct a seconr. moveable platform, which was PLucured and installed over tank W-6 in Mar 2 h 1982.

The necessary support documents including the Quality Assurance Plan, Quality Assurance Assessment, Preoperating Checkout and Calibration Procedures, Operating Procedures, Final Safety Analysis Report (FSAR), and Operating Safety Requirements (OSR) were prepared, reviewed by appropriate groups, approved, and issued. In addition to ORNL approval, the FSAR and OSR were reviewed and approved by DOE-ORO.

Instrument checkout and preoperational testing began in February and extended through June. Minor modifications in equipment and operating procedure were made as a result of the testing program. The office of Operational Safety and the Radioactive Operations Comittee conducted a preoperational review in late June followed by ORO review in early July. Both groups promptly indicated approval to initlate operations; sluicing began on July 12 .

Sluicing and perfodic transfer of the suspended sludge to the Hydrofracture Facility continued to the end of the year. Early sluicings produced waste batches with undesirably low solids content. In September, a redesigned screen was installed on the suciion leg in tank $W-5$, and a 
hydraulic pump was installed on the movable section of the leg so the screen could occastonally be raised for washing with the sluicer. This change has resulted in a favorable increase in slurry solids concentration. As noted in section 8.2.2, two Injections of suspended sludge waste have been made: approximately $184,000 \mathrm{gal}$ the week of August 9 through August 15, and approximately 120,000 gal the week of September 20-24. Operations are currently continuing in '-ank $W-5$; and tank $W-6$ is being readied to receive the sluicing equipment when tank $\mathrm{W}-5$ is empty. 


\subsubsection{Site Specific Low-Level Waste Studies. (D. D. Huff, J. Switek, C. R. Olsen, C. S. Haase, F. G. Taylor, P. D. Parr)}

The primary purpose of the Site Specific Low-Level Waste Studies task is to provide environmental research and development support to solve low-level radioactive waste management problems at ORNL. The major objectives of the work are to:

1. Identify environmental factors that affect waste disposal operations at ORNL,

2. Determine the potential impact of waste disposal operations on enviromental safety and regulatory compliance, and

3. Determine and recommend procedures to ensure that environmental safety and regulatory goals are met.

The following subtask descriptions present summaries of activities directed toward meeting the objectives described above.

\subsubsection{SWSA 4 Studies}

The primary purpose for SWSA 4 investigations is to supply information needed to satisfy the objectives of upgrading and achieving long-term stabilization of the burial ground. Since SWSA 4 is the most important contributor of ${ }^{90} \mathrm{Sr}$ to White Oak Creek (8.1), it has been the fncus of detailed studies of the distribution of ${ }^{90} \mathrm{Sr}$ as well as mechanisms for the hydrologic ransport of ${ }^{90} \mathrm{Sr}$ from disposal trenches (8.2). These studies have resulted in plans for a surface water diversion to capture uncontaminated runoff from the up-slope portions of the SWSA 4 watershed and divert it to other basins. Construction 
is expected to be completed in 1984. In the meantime, more detailed characterization of the nature and extent of radionuclide contamination susceptible to transport by groundwater runoff from within SWSA 4 has proceeded. A $30 \times 30 \mathrm{~m} \mathrm{grid} \mathrm{system} \mathrm{has} \mathrm{been} \mathrm{extended} \mathrm{into} \mathrm{the} \mathrm{region}$ of most active ${ }^{90} \mathrm{Sr}$ transport and is being used to accurately determine the spatial distribution of radionuclide distribution there. A surface contamination survey on $5 \times 5$ m centers has revealed patterns that suggest releases from several individual sources rather than a general broad area source that might be expected as a result of contaminated groundwater discharge over an extended area. Soll samples collected using a percussion-driven coring device have been subjected to gamma-scintillation analysis and show presence of both ${ }^{137} \mathrm{Cs}$ and ${ }^{60}$ Co. Cesium-137 contamination is presert primarily at the ground surface. Cobalt-60 shows highest concentrations at 0.3 to $0.5 \mathrm{~m}$ below ground at locations where it is present. The nature of the 3-dimensional distribution pattern strongly suggests that the spread of contamination results from the "bathtub" effect within several individual trenches in low-1ying areas. These trenches, winfch were constructed perpendicular to contour lines, collect water and overflow to the ground surface at the downslope end rather than releasing contaminated water to the surrounding soils for subsequent groundwater transport. It is expected that this shortened pathway will be reduced to a minor role by the diversion of upslope runoff when the diversion construction is completed in 1984. However, evaluation studies are continufing and the need for additional stabilizing measures will only be 
determined for certain after the surface runoff diversion project has been completed.

\subsubsection{SWSA 3 Studies}

Stueber et a1. (8.3) noted that Solfd Waste Storage Area 3

appeared to supply small quantities of ${ }^{90} \mathrm{Sr}$ not only to the Northwest Tributary (NWT) of White Oak Creek but also to Raccoon Creek which lies outside the White Dak Creek watershed. The suspected transport pathway was by way of a solution cavity labyrinth that parallels the geologic strike. In order to further delineate the nature of this solution network and to allow the development and demonstration of corrective measures to be used in shallow land burial grounds sited in carbonate ( 1 imestone or dolomite) rocks, further characterization using dye tracer tests, water chemistry analyses, and geologic studies has been pursued.

8.2.5.2.1 Dye Tracer Tests. Dye tracer experiments have confirmed that SWSA 3 is the source of radiostrontium to seeps on Raccoon Creek and the Northwest Tributary (NWT) to White Oak Creek. The relative intensity of dye reaching the NWT and the Raccoon Creek seep (Fig. 8.15) Indicates that a spring on the NWT (the D-270 seep) is the major reciplent of radionuclides migrating from SWSA 3 . This spring should be an excellent monftoring point for assessing the effectiveness of any remedial actions implemented at SWSA 3. Breakthrough of tracer to both Raccoon Creek and NWT reveals that the ground drainage water divide is approximately $100 \mathrm{~m}$ further east than previously believed. It now appears that the entire southwestern portion of 
Or.iAl-ow6 a2-19314

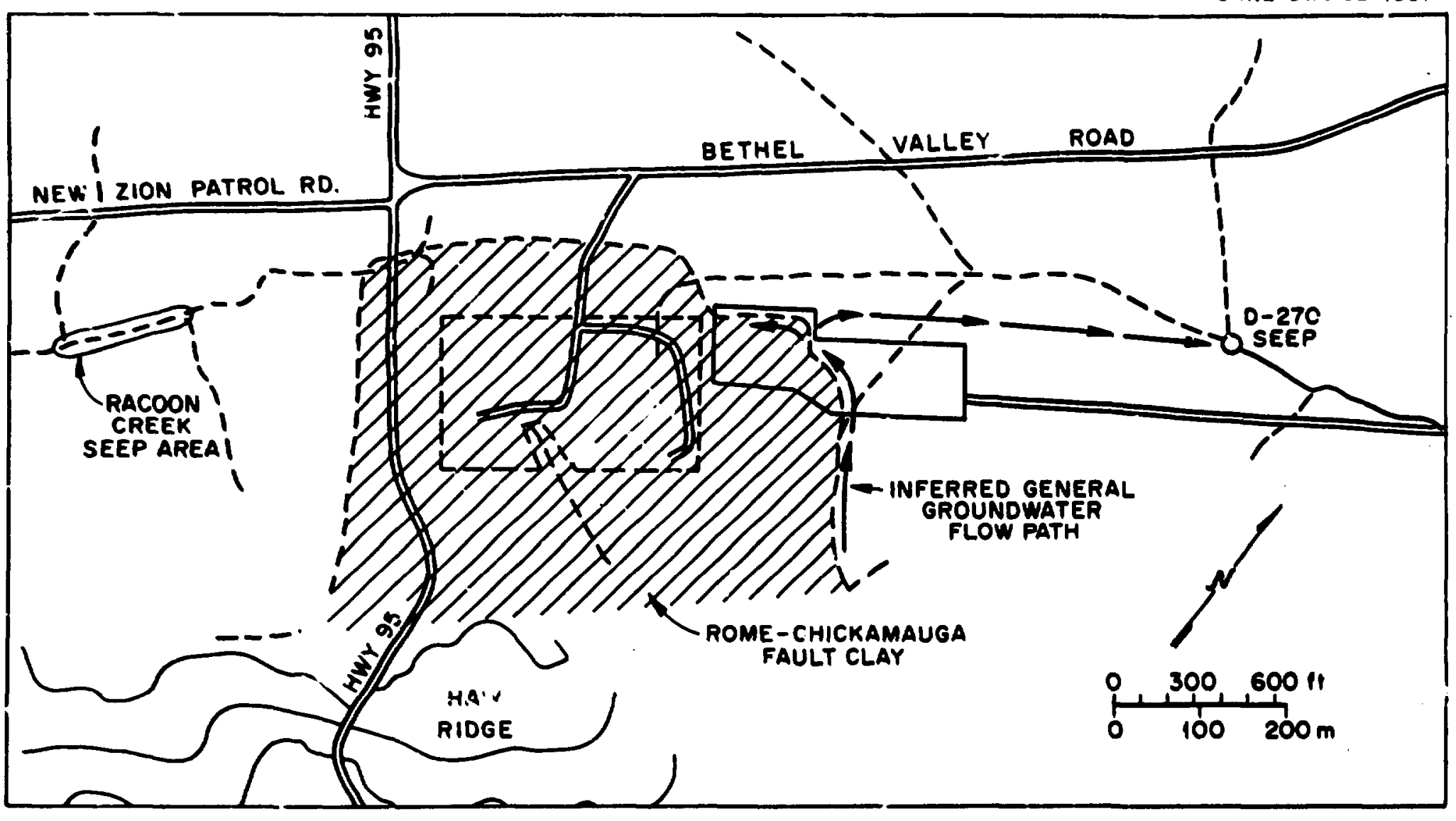

Fig. 8.15. Map of the SWSA 3 area, ORNL, showing contaminated seeps and the appropriate location of the Rome-Chickamauga fault clay deposit. 
SWSA 3 contributes groundwater to the Raccoon Creek drainage urder appropriate conditions. The fact that the concentration of ${ }^{90} \mathrm{Sr}$ discharged to Raccoon Creek (2 Bq/L) represents only 17 of the corresponding concentration in water discharged to $\mathrm{NWT}(200 \mathrm{~Bq} / \mathrm{L})$ may be misleading in that the distance from the infection well ( $7900 \mathrm{~m}$ ) to the Raccoon Creek seep is almost double the distance to the NWT seep (500 m) and dilution and dispersion may be considerable. Samples collected at a point on NWT approximately 900 feet from the injection well contained ${ }^{90} \mathrm{Sr}$ in concentrations of the same order of magnitude as those collected at the new Raccoon Creek seep (8.3). On the other hand, it must be noted that stream discharge at Raccoon Creek seep is much less than at Stueber's sampling point on NWT.

\subsection{Water Chemistry Analysis. Sampling of SWSA 3 wells} and streams has shown that most waters in the vicinity are of a calcium-bicarbonate type as is expected in a limestone aquifer system. However, several wells (including all wells within the SWSA 3 ?ence) show elevated levels of sodium, potassium, sulfate and chloride. Tins presumably represents contamination from waste trenches but it could also be due to other activities such as addition of fertilizer to the grass. Well-bore muds will be analyzed to further evaluate this situation. Radionuclide analyses of the SWSA 3 area waters has shown that almost all the wells surrounding the sfte can contain detectable ${ }^{90}$ Sr and several contain detectable ${ }^{60} \mathrm{Co}$ and $\approx$ lpha contamination. This Indicates that the groundwater flow system witlin and around the burlal ground $1 \mathrm{~s}$ quite complex although on a larger $\left(10^{2} \mathrm{~m}\right)$ scale 
the system appears to be dominated by a small number of solution cavity flow paths.

\subsection{Geological Studies. Reconnaissance level geological} investigations around SWSA 3 suggest that the southwestern end of the area is underlain by fault gouge-clay that marks the thrust faulted contact between limestones of the Chickamauga Group and the older, overlying Rome Formation (Fig. 8.15). Stratigraphic cross sections prepared from logs of SWSA 3 wells drilled in 1949-50 do not show significant deformation of Chickamauga rocks related to this thrusting event. The contact between the clays of the fault gouge and outcropping limestones on the eastern side of SWSA 3 appears to be a major groundwater flow zone feeding water directly into the middle of the burial ground from a small catchment area on Haw Ridge. The area at the base of this catchment, just outside the fence, is ail old landfill with one trench about $100 \mathrm{~m}$ long (not shown). The disturbed ground probably increases the amount of water storage in this arca and releases water to the burial ground over a prolonged pertod of time. It may be possible to install a grout curtain or french drain between this fill area and SWSA 3 to direct water away from the buried wastes. Alternatively, a drain could be installed at the top and a bentonite cap placed over the landfill itself. Future studies will involve drilling a well into the area and conducting a dye tracer test to establish the hydrologic connection between this area and NWT. Sefsmic surveys will be run to determine the position of the clayIimestone contact more accurately. 


\subsubsection{SWSA 7 Siting and Characterization}

Within approximately 10 years new disposal facilities for sclid low-level radioactive waste will be required at ORNL. SWSA 7 is intended to receive higher activity low-level waste and characterization of a proposed site has begun. Groundwater levels in the proposed SWSA 7 were monitored in 11 wells throughout the year. Seven of the original wells were redrilled to $30 \mathrm{~m}$ and four of these were finished with multiple screens to permit study of deeper levels of groundwater flow. In September, three additional $30 \mathrm{~m}$ wells with multiple screens were installed. Thus, by September 30, 1982, groundwater monitoring was being conducted with a total of 14 wells, 4 of which are $10 \mathrm{~m}$ in depth and 10 of which are $30 \mathrm{~m}$ in depth. In adjition, a rain gauge has also been installed to measure precipitation at the site.

Making use of the observed minimum depth to groundwater level from calendar year 1981 (measured from land surface), and land surface slope data a preliminary map fllustrating the potential usable land areas for conventional shallow land burfal practices has been constructed (Fig.8.16). The cross-hatched regions in Figure 8.16 represent potentially usable area where the depth of groundwater is greater than five meters and the slope is $25 \%$ or less. The size of the region is approximately 10 hectare ( $\sim 24$ acres). This value is very dependent on the minimum acceptable depth to groundwater value assumed in construction of the map. If a value of two or three meters for this parameter is acceptable then the usable area would 
ORNL-DWG 82-19325

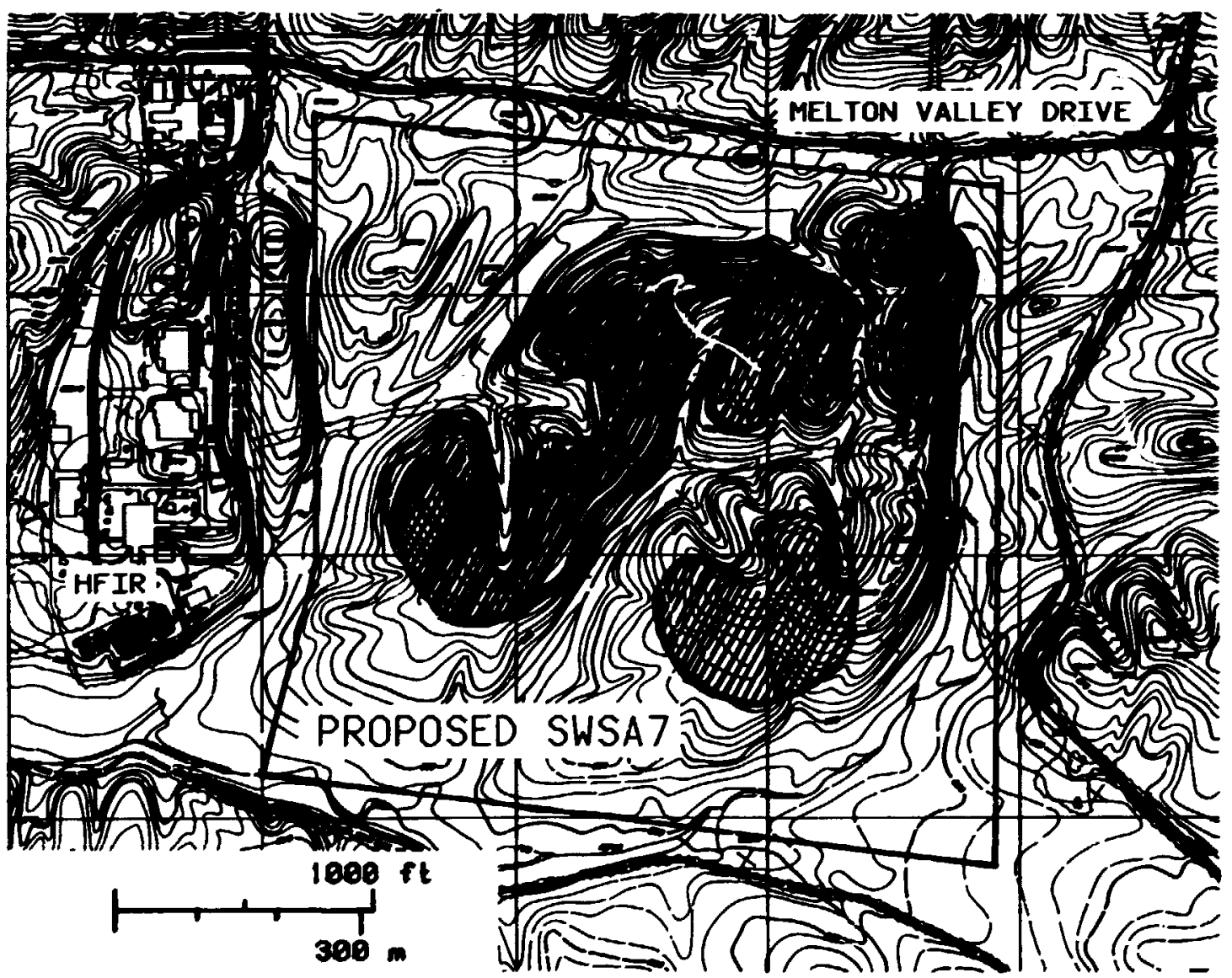

Fig. 8.16 Map showing the general area encompassed by proposed SWSA 7. Regions encloset within the solid lines in the center of the figure are potentially usable portions that have a depth to groundwater greater than $f$ ive meters. Within these regions the crosshatched portions are areas where the slope of the land surface 18 less than $25 \%$. 
increase significantly, perhaps by a factor of two or three. The appropriate value for this paraneter and the value of the maximum acceptable surface slope will be deternined by the disposal technology to be enployed at SWSA 7. The extent of the potentially usable region illustrated in Figure 8.16, therefore, must be considered as tentative at this stage of engineering and design for SwSA 7 .

To provide measurement of surface-water discharge from SiSA 7, a critical-flow flune with complex cross section has been designed, fabricated and installed on the primary strean that drains the proposed disposal area. The flume was designed to frovide accurate measurement of discharge over a wide range in flow rate and at the same time cause minimal ponding of water upstream. The design parameters were finalized using an interactive computer program (8.4) together with field-determined estimateg of downstream channel capacity. Since the flume represents an experiment in the performance of low head-loss measuring structures, it was fabricated frow plywood to minimize costs. It has been installed on a concrete foundation that should allow for changes in design, should they be found necessary.

Barly indications are that the flumperforms well enough to measure flow within $\pm 3 \%$ at very low flow rates. Bvaluation of the design will continue and be the basis for more permanent structures in future years. 


\subsubsection{ILW Pits and Trenches}

From 1951 to 1966 seepage pits and trenches were used for the disposal of intermediate-1evel liquid wastes (ILW) at Oak Ridge National Laboratory (ORNL). These waste pits and trenches were excavated in weathered Conasauga Group and backfilled with crushed 1imestone. Waste 1iquids (adjusted to a $\mathrm{pH}$ of $\sim 12$ with NaOH) were allowed to percolate through the weathered rock $(\mathrm{pH} \sim 5)$ and radionuclide migration was retarded by reactions with the fill and soil. Over one million curies of fission products $\left(\sim 75 \%{ }^{137} \mathrm{Cs}\right.$ and $\sim 25 \%$ ${ }^{90}$ Sr) with some activation products, actinides and transuranics were disposed in this manner prior to the implementation of deep-well hydrofracture.

Groundwater samples have been collected on a monthly basis from $\sim 35$ wells in the vicinity of these formerly used ILW pits and trenches. These samples have been routinely analyzed for $\mathrm{pH}^{3} \mathrm{H}$, ${ }^{90} \mathrm{Sr},{ }^{137} \mathrm{Cs}$ and ${ }^{60} \mathrm{Co}$. Selected samples have also been analyzed for other radionuclides (Including ${ }^{99} \mathrm{Tc},{ }^{233} \mathrm{U}$ and transuranics) and water chemical characteristics $\left(\mathrm{LCO}_{2}, \mathrm{Eh}, \mathrm{PO}_{4}, \mathrm{Fe}, \mathrm{Mn}\right.$, etc. $)$. Data concernIng the chemical properties of the water have been used to help identify the geochemical factors and complexes which may influence nuclide solubility. Cnce in solution, nuclide nigration from these waste disposal sites is controlled primarily by local hydrological flow patterns which are governed to a great extent by local geological features, such as folds, faults, and zones of greater weathering. 
Concentrations of ${ }^{3} \mathrm{H},{ }^{60} \mathrm{Co},{ }^{233} \mathrm{~J},{ }^{238} \mathrm{Pu}$ and ${ }^{99} \mathrm{TC}$ in the groundwaters around the ILW pits and trenches may range as high as 12,000 $\mathrm{Bq} / \mathrm{L}, 1700 \mathrm{~Bq} / \mathrm{L}, 41 \mathrm{~Bq} / \mathrm{L}, 0.06 \mathrm{~Bq} / \mathrm{L}$ and $3200 \mathrm{~Bq} / \mathrm{L}$, respectively. The distribution of ${ }^{3} \mathrm{E}$ has been used to delineate contaninated flow paths. Compleration of ${ }^{60}$ Co with a soluble chelating agent (EDTA) has been the reported cause for its high mobility. Experinents to positively identify the chenical speciation of mobile ${ }^{60} \mathrm{Co}$ are presently in progress. The mobile ${ }^{233} \mathrm{U}$ species is a low molecular weight anionic complex, probably a carbonate complex, but the possibility of a phosphate complex has not been ruled out. Between 20 and 507 of the dissolved ( $<0.45 \mu \mathrm{m}){ }^{238} \mathrm{Pu}$ in the groundwaters is in an oxidized (V, VI) state. It is suspected that the ${ }^{238} \mathrm{Pu}$ contamination in these groundwaters actually reflects the movement of Its parent ${ }^{242} \mathrm{Cm}$ at the original time of disposal rather than the subsequent migration of ${ }^{238} \mathrm{Pu}$. The high concentrations of long-lived ${ }^{99}$ Tc $(210,000 \mathrm{~g}$ half1ife) in the groundwaters probably reflects its mobllity as a negatively charged pertechnetate $10 n, \mathrm{TcO}_{4}{ }^{-}$, which is stable in slightly oxidizing aqueous solutions. At present, levels of ${ }^{90} \mathrm{Sr}$ contamination in these groundwaters are relatively low $(<1 \mathrm{~Bq} / \mathrm{L})$ as a result of retardation by reactions of the alkaline waste with Ca-Mg carbonates in the soil or crushed limestone fill.

A detailed site characterization of the geochemical, hydrolog1cal and geological factors governing radionuclide migration 18 presently being undertaken at ILW Trench 7. Th1s site was chosen because of the occurrence of ${ }^{60} \mathrm{Co}$ and ${ }^{233} \mathrm{U}$ in a surface seep which 
appears in a valley $\sim 50$ aeters east of the trench. Groundwater ${ }^{60} \mathrm{co}$ and 233 concentrations undergo a seasonal variation at this site with the highest activities occurring in the springtine. The seasonal rise in muclide activity is correlated with a rise in the groundwater level and a concurrent ncrease in groundwater pH. This suggests that during spring, the water table may rise to saturate the alkaline f111 in the trench or contaminated soils near the trench and thus pronote nuclide migration.

Two suspected migration pathways of contaminated water from the trench to the nearby seep have been Identified on the basis of nuclide concentrations, inflections in the groundwater table, groundwater compositions, field seismic surveys and local geologic structures. Both pathways appear to be associated with fault zones which strike parallel to a line drawn from the trench to the seep area. A series of wells drilled parallel to the trench and across these fault zones (open circles in Figure 8.17) Indicated an inflection in the groundwater table, rising sharply to the north of well T7-23. Selsmic refraction results were too complex for unequivocal interpretation but definitely indicated structural discontinuities at $77-21$ and $77-23$. Along this series of wells, a geologic cross section was exposed parallel to the trench by widening the banks of an already existing access road. This exposure delineated a fault zone at T7-21, a large anticlinal fold at I7-23 and another fault zone at T7-25 (F1gure 8.18).

Groundwater analyses Indicated that the greatest contanination ocrurred in wells drilled through the fault zones and little or no 


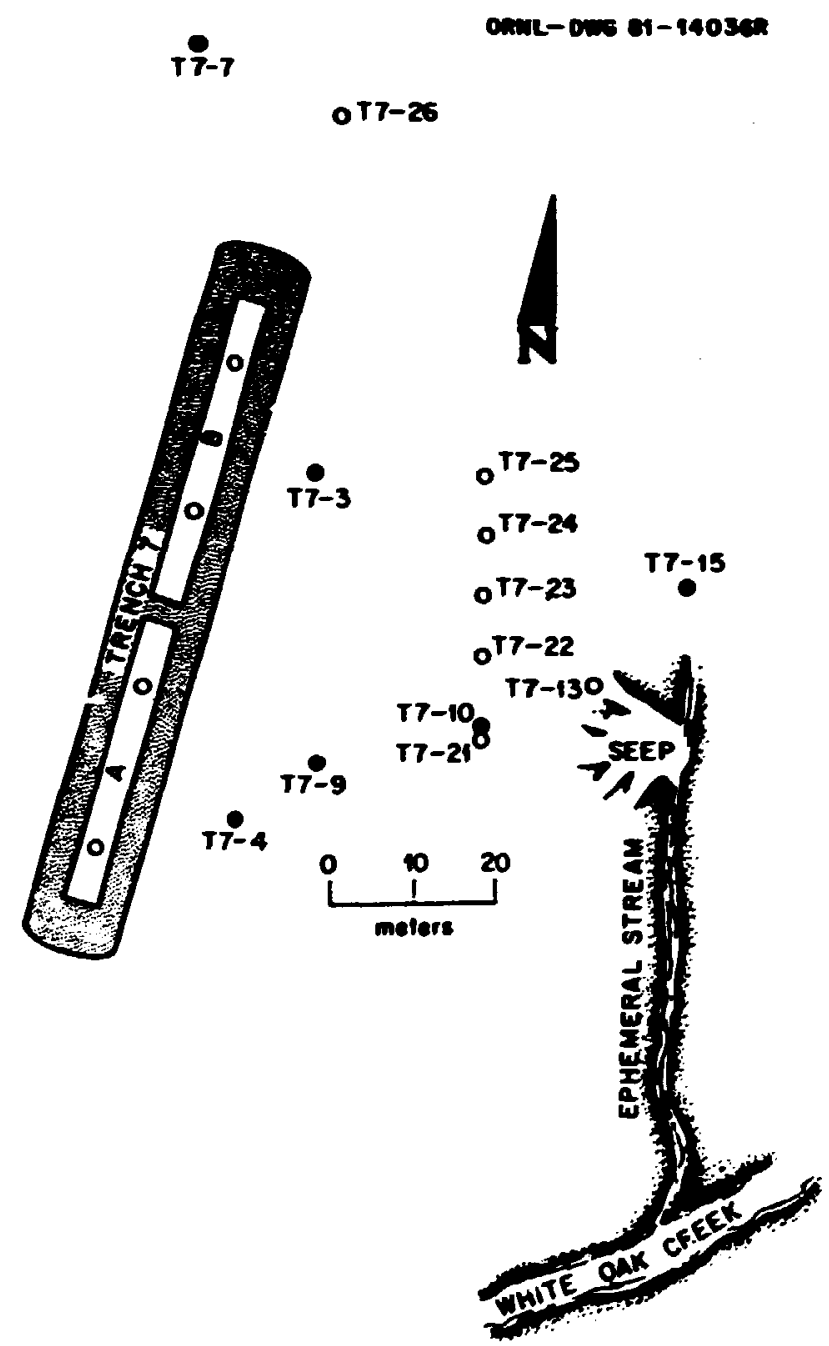

Figure 8.17. Areal map illustrating the location of previous wells (closed circles) and new wells (open circles) in the vicinity of ILW Trench 7 . 
contamination in the groundwater capped by the limestone fold (Table 8.3). Well T7-21, which is not shown in Figure 8.18, is a 15 meter well which penetrates a fault zone $\sim 8$ meters to the south of well T7-22. This fault zone is delineated by a topographic gully, along which several shallow 9 meter wells (T7-4, T7-9, T7-10 in Figure 8.17) were drilled over a decade ago. These shallow wells did not penetrate deep enough to tap ihe contaminated flow fath as indicated by gamma-ray borehole logs and a comparison of the nuclide data for vells T7-21 and T7-10 in Table 8. Although ${ }^{60} \mathrm{Co}$ and ${ }^{99} \mathrm{Tc}$ concentrations in groundwaters of T7-21 are high, the alkalinity, $\mathrm{pH}$ and ${ }^{233} \mathrm{U}$ concentrations are relatively low suggesting that this pathway is not presently :ransporting contamination from the trench itself but rather is a relict pathway which was active during past disposal operations.

The high alkalinity and $\mathrm{pH}$ of the groundwaters in wells $\mathrm{T} 7-24$ and T7-25 along a fault zone at the north end of the trench (Figures 8.17, 8.18) In addition to the high ${ }^{60} \mathrm{Cn},{ }^{99} \mathrm{Tc}$ and ${ }^{233} \mathrm{U}$ concentrations (Table 8.3) indicate that this pathway is presently transporting contamination from the north end of ILW Trench 7 to the seep area in response to the spring rise in the groundwater level. A new series of wells and soil borings are presently being drilled at the north end of the trench to evaluate the above mechanfom and pathway for nuclide mobllization and transport, and the effectiveness of a french drain, groundwater Interceptnr as a remedial action plan to retard nuclide migration along this pathway. 
Table 8.3. Contamination Levels in Wells Near ILW Trench $7^{1}$

\begin{tabular}{lrrrrrr}
\hline $\begin{array}{c}\text { We11 } \\
\text { Number }\end{array}$ & $\mathrm{pH}$ & $\begin{array}{c}{ }_{\mathrm{H}} \\
(\mathrm{Bq} / \mathrm{L})\end{array}$ & $\begin{array}{c}{ }^{90} \mathrm{Sr} \\
(\mathrm{Bq} / \mathrm{L})\end{array}$ & $\begin{array}{c}{ }^{99} \mathrm{Tc} \\
(\mathrm{Bq} / \mathrm{L})\end{array}$ & $\begin{array}{c}{ }^{60} \mathrm{Co} \\
(\mathrm{Bq} / \mathrm{L})\end{array}$ & $\begin{array}{c}{ }^{233} \mathrm{U} \\
(\mathrm{Bq} / \mathrm{L})\end{array}$ \\
\hline $\mathrm{T} 7-10$ & 6.5 & $40 \pm 100$ & $0.4 \pm 0.2$ & - & $89 \pm 3$ & $0.2 \pm 0.1$ \\
$\mathrm{T7}-21$ & 6.9 & $29000 \pm 1000$ & $<0.1$ & $3200 \pm 100$ & $2680 \pm 67$ & $1.6 \pm 0.2$ \\
$\mathrm{T7}-22$ & 7.3 & $10000 \pm 1000$ & $<0.1$ & - & $1090 \pm 41$ & $0.3 \pm 0.1$ \\
$\mathrm{T7}-23$ & 7.1 & $10000 \pm 1000$ & $0.9 \pm 0.3$ & - & $<4$ & $<.1$ \\
$\mathrm{T7}-24$ & 7.3 & $6700 \pm 1000$ & $<0.0$ & $400 \pm 10$ & $2180 \pm 11$ & $2.3 \pm 0.3$ \\
$\mathrm{T7}-25$ & 8.9 & $5600 \pm 1000$ & $1.6 \pm 0.4$ & - & $1820 \pm 30$ & $15.0 \pm 2.0$ \\
\hline
\end{tabular}

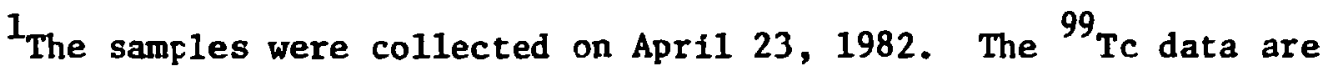
for samples collected on July 23, 1982. 


\section{ORNL-DWG 81-21573B}

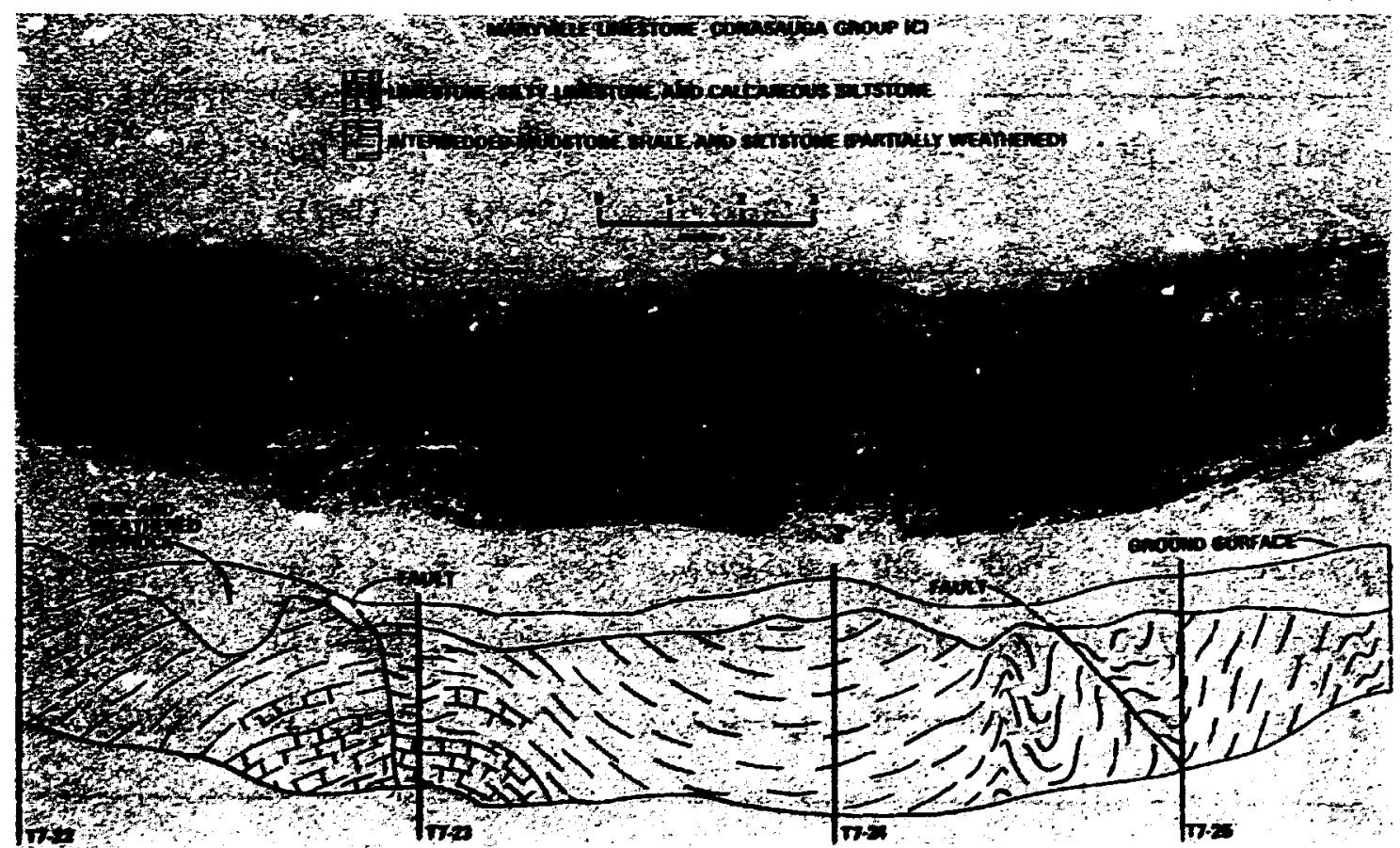

Figure 8.18. Cross-sectional photo and map illustrating the geological structures which strike between ILW Trench 7 and a nearby contaminated seep. Several wells (for which radionuclide data are presented in Table 1) are located in relation to the geologic structures. 


\subsubsection{Long-Term Vegetation Managenient}

The use of vegetative covers other than grass or change in maintenance of the current grass cover may be advantageous for both short-term and long-term management of former solid low-level nuclear waste disposal sites. The "Ideal vegetation cover" would require low or no maintenance, have a high water denand, a shallow root profile, cause negligible radionuclide uptake, and be capable of successful competition with Invading successional species.

Plant species with potential for use as ground cover on the lowlevel waste disposal areas were identified through a literature review. Vegetational types evaluated Included successional grass stages, successional thicket stages, shallow-rooted lawn grass spectes, drought-tolerant lawn grass species, prairie grass species, herbaceous horticultural species, forbs and weeds, low shrub species, tall surub species and trees. No one particular speries or vegetational type emerged as fulfilling all requirements for the "ideal" cover.

Based on the literature revtew, natural succession stages may be promising, although the stabilizing of particular stages may require some maintenance. Broomsedge fields, for example, will not require fertilization, have a suiftciently shallow root profile, and are relatively stable if mowed annually. Thicket or vine stages (e.g., honeysuckle, kudzu, sumac) may cause problems with regard to invading deeprooted species. A grass cover (as presently maintained on the disposal areas) requires greater labor-intensive (mowing, fertilization) care, but can provide the least risk of root mining as long as deep-rooted, drought resistant species are avolded. A dense thicket of ornamental 
shrubs (sumac, spiraea, forsythia, jasmine) can be obtained if shrubs are pruned back occasiona:ly. of the herbaceous ornanental species, yellow root, groutweed, bamboo and lilyturf or a conbination of thege wth perivinlale, bugleveed, and English ivy can be effective. Ornamental shrubs and herbs wili require some maintenance also Geriodic weeding, pruning, pest control).

Some possibflities may exist for low-maintenance arboreal vegetation. For example, prelininary work rith simulation models indicates plantations of certain early successional species way provide sultable vegetation cover while requiring infrequent, labor-intense manipulation. Species such as red maple or white ash may have proper rooting characteristics, sprout rearily when harvested, and can regenerate and maintain, through copficing (s unap sprouting) on a 20-year cycle, leaf areas suitable for relatively high evapotranepiration. Current work with the modeling effort also indicates highiy variable growth under different moisture and nutrient regimes.

The long-term objective of the research is to demonstrate tinat Improved $v \in g e t a t i v e$ covers are avallable aud to provide a sound basis for recommending the type of cover best suited for a particular disposal area. This will be evaluated locally through a series of demonstration plots and extrapolated reglonally through modeling efforts utilizing forest types and variable enviromental conditions typical of the Southesst. 


\subsubsection{Kelton Valley Geology}

Research this past year has focused on the regional stratigraphic character of the Conasauga Group throughout east Tennessee and on the refinenent of the general stratigraphic and petrologic understanding of the Conasauga Group at the Dak Ridge locality. The purpose of this subtask is to characterize the sedimentology, stratigraphy, and petrology of the Conasauga Group so that its role af a host formation for the hydraulic fracturing and the shallow land burial operations at ORNL can be better evaluated.

Regional stratigraphic studies were based on an extensive compilation of data from puolished and unpublished sources. Lithofacies and Isopech maps in conjunction with stratigraphic crcos sections of the Conasauga Group and its constituent formations in east Tennessee were prepared as both present day and palinspastic bases (8.5).

Examination of the present-day base 1sopach snd Iithofacies maps resulted in the identification of spatial and temporal patterns of 1ithofacies distribution that are generally consistent with those outlined by Rodgeis (8.6). Such patterns suggest that the Conasauga Group was deposited on a passive continental margin in a shallow marine shelf setting. Psamination of the data plotted on a restored palinspastic base, which removes the effects of depositional thrust faulting, demorstrates that the pre-thrusting lsopach and 1ithofacies patterns are not consistent with the sfmple shallow marine shelf depositional setting. Instead the data suggest the following features for the regional depositional setting for the Consaaga iroup: 
(1) depositiona settings ranged fro dominantly marine to locally peritidal and sedinentation occurred on a northeast-8outhiest trendIng continental shelf ( $300-500$ w wide) that contained on intra-bhelf basin (100 $200 \mathrm{k}$ wide) that closed to the southest and opened to the northeast aiong an axis apprc efsately parallel to the trend of the sheif argin, (2) the eastern margin of this intra-shelf basin consigts of shaly linestones and dolostones that becone doninatily dolostones eastward of the basin margin; (3) Intra-sheif basin sedihents consist ainly of shales, siltstones and shaly Iinestones; and (4) the western wargin of the basin consists mostly of siltstones, shales and calcareous shales that becone doninantly clastic-rich westward of the basin. These conclusions about the Conasauga Group depositional setting and lithofacies distribution patterns for the east Tennessee region agree well with the shelf-intrashelf basincarbonate ramp shelf margin model proposed for the Nolichucky shale and upper Conasauga Group equivalents in southrest Virginia by Markello and Read (8.7). The results of this stidy provide information about the southern extent of the intra-shelf basin described by Marke1lo and Read $(8,7)$ and about nature of the Conasauga Group depositional setting southrard of the area studied by then. Results of this regional stratigraphic study indicate that the Conasauga Group that occurs at the Oak RIdge locality was deposited on the restern edge of the Intra-shelf basin but eastward of the western basin margin. The abundance of clastic-rich material and the complexiy interfingered nature of clastic-rich and carbonate-rich 1ithologies within the 
Consamiga Group at the Oak Ridge locality are consistent wth such a depositional setting.

Local stratigraphic investigatious of the Conasanga Group in the White Oak Ho ain and Copper Creel thrust blocks to date $(8,8)$ have been based on Ifnited outcrop data and videly scattered dianond drill cores. To provide a conplete reference stratigraphic section of the Conasauga Group for the Copper Creek thrust block (Helton Valley) a deep borehole drflling project was began tn angust of 1982 . The goal of this project is to obtain a continuous rock core of the Conasauga Group and the underlying Rone Formation. The rock core will allow an unabiguous correlation of merous fragnentary rock cores of Conasauga Group matertal obtained previously from throughout the DOE Oak RIdge Reservation. It will also provide stratigraphically well-characterized samples for use in geophysical well logging studies planned for II 1983. As of October 26, 1982, the deep borehole had been drilled to a depth of 730 a ( 2400 feet); total depth of the borehole will be approximately $900=(\sim 2900$ feet). 

Table 8.4. Properties of grouts 1 ade from different trade mames of Attapulgite clay

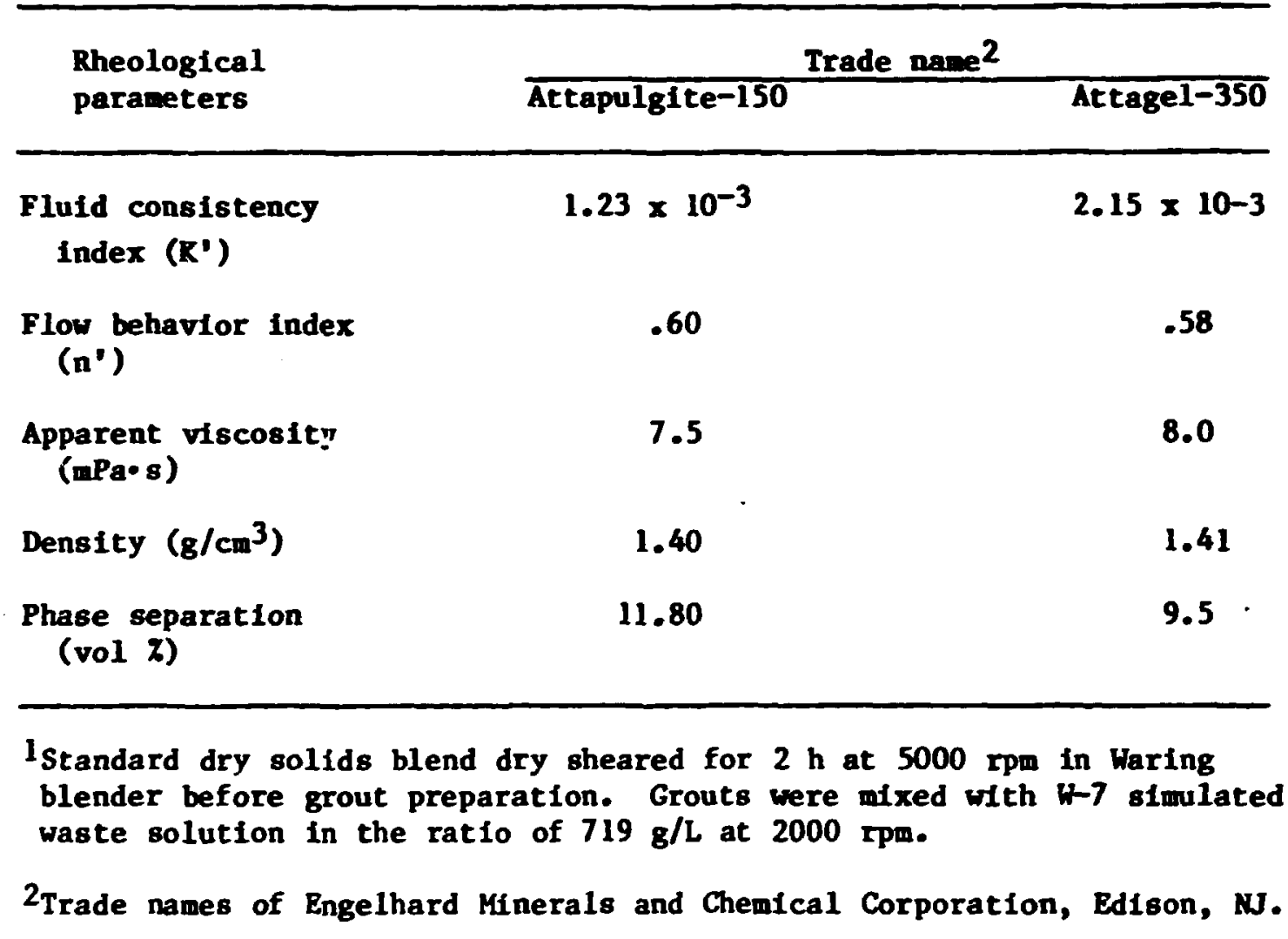


A prelininary conclusion to be drawn from this work is that it is necessary to have solids blended as homogeneously as possible to insure acceptable grout rheology.

\subsubsection{Task 2: Leach Studies}

Strontiun leach studies of hydrofracture sludge-slurry grouts were completed and reported in ORN/nt-8198 in March 1982. The results obtained In this study Indicate that use of the modified IAEA leach procedure and the Joy-Godbee model gives an apparent diffusion coefficlent of $5 \times 10^{-12} \mathrm{~cm}^{2} / \mathrm{s}$ and a moving boundary coefficient of $1 \times 10^{-7}$ $8^{-1}$ for one of the best grout formulations in distilled water (Fig. 8.19).

\subsubsection{Task 3. Injection Assistance}

The jor effort in this task is to determine the dry solids blend and amount to be used for a given waste stream. This is performed prior to the injection. Samples of dry solids are taken at specific intervals during an injection and grouts are prepared with a simulated waste as a quality assurance measure. Based on viscosity calculations from data on the sludge-suspensions that were transferred from the south tank farm to the new hydrof racture (NHF) site holding tanks, the amount of dry solids per gallon of sludge to be used was determined using a theogram that relates flow properties of these sludge-slurry grouts to previous pumpab.e grouts made with waste solutions.

Grouts were prepared whth dry solids taken from the hydrofracture site's welghbelt feeder, at approximately $46,000 \mathrm{~K}$ intervals during the first injection of gunite tank sludge (Aug. 9-15, 1982). Grouts 
ORNL-DWG 82-166R

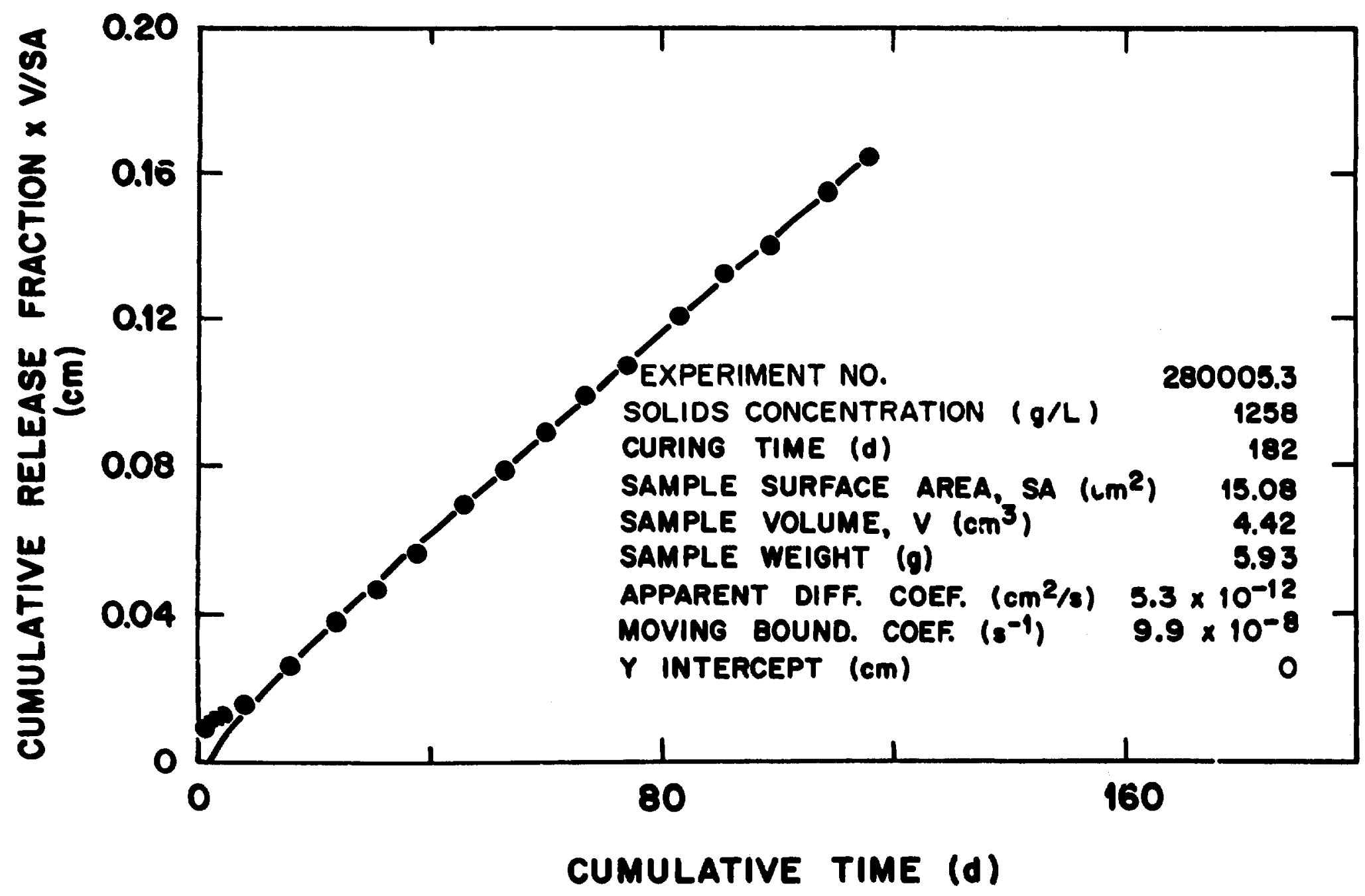

F18. 8.19. Fraction of strontlum leached vs time from sample 280005.3 , cured 182 d. 
were ade frow these samples as a quality assurance (QA) verification of quality control (QC) procedures, which were followed during the dry sollds blending operations. Characteristics of these grouts (Table 8.5) show that the solids in T-8 and T-9 silos were blended uniformly and verify that the site operations conscientiously maintained the dry solids blends within the QC linits during preparation for the SI-1 injection.

\subsubsection{Task 4. Nuclide Mgration Studies}

Studies were Inttlated in FY 1982 to characterlze hydrofracture grouts in terms of phase composition and microstructure. Numerous grout samples containing simulated waste solutions or sludges are currently being Investigated by optical microscopy, X-ray diffraction, and scanning electron microscopy. Fracture surfaces, polished surfaces, and crushed samples are being examined to identify the phases present. We are currently learning to Identify fly ash, calcium hydroxide, and the cementitious phases of tobermorite, ettringite, calcium aluminoferrite hydrate, and tetracalcium aluminate hydrate.

A core-drilled sample of hydrofracture grout injected nearly 18 years ago was examined by optical microscopy, scanning electron microscopy, and $X$-ray diffraction. The X-ray diffraction results revealed that the grout consisted primarily of calcite $\left(\mathrm{CaCO}_{3}\right)$, vaterite $\left(\mathrm{CaCO}_{3}\right)$, portlandite $\left[\mathrm{Ca}(\mathrm{OH})_{2}\right]$, and $\mathrm{Ca}_{2} \mathrm{~S}_{10}$. Fortunately grout samples prepared In the laboratory produced the same phases as actual grout sheets injected into the shale layer and cured in-situ. The core-drilled sagple had no quartz or mullite present indicaring that no fly ash had 
Table 8.5 Comparison of grout properties made with dry solids taken at different places in T-8 and T-9 31108 during SI-1 injection

\begin{tabular}{|c|c|c|c|c|c|c|}
\hline \multirow[b]{2}{*}{$\begin{array}{l}\text { Grout }^{2} \\
\text { parameter }\end{array}$} & \multicolumn{3}{|c|}{$T-8$} & \multicolumn{3}{|c|}{$T-9$} \\
\hline & $\frac{\text { Anou }}{136,363}$ & $\frac{E \ln 8110}{100,000}$ & $\frac{\left(\overline{\left.K_{g}\right)}\right.}{31,818}$ & $\frac{\text { Amount }}{106,818}$ & $\frac{\ln 8110}{86,363}$ & $\frac{(\mathrm{Kg})}{45,454}$ \\
\hline Apparent viscosity (cP) & 35.5 & 34.0 & 35.5 & 36.0 & 35.0 & 34.0 \\
\hline Density $\left(g / \mathrm{cm}^{2}\right)$ & 1.45 & 1.44 & 1.44 & 1.45 & 1.44 & 1.44 \\
\hline Phase separator (Vol $x$ ) & 3.70 & 3.75 & 3.75 & 3.74 & 3.75 & 4.16 \\
\hline
\end{tabular}

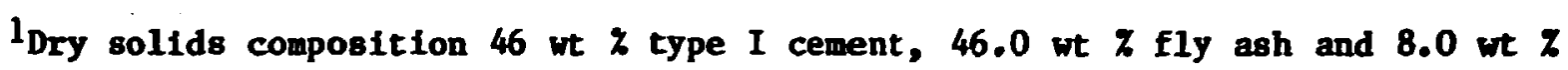
pottery clay.

2Mixed in the ratio of $719 \mathrm{~g}$ of dry 8011 ds per liter $(5.51 \mathrm{~b} / \mathrm{gal})$ of a 15 wt $z$ sludge that has a viscosity of $9.0 \mathrm{cP}$. 
been added to the grout. Because fly ash was added to all Injections since experimental injection $81 x$, the core-drilled sample must be from one of the first five experimental injections. Further analytical exanination Identified the radionuclides as $90_{\mathrm{Sr}}, 137 \mathrm{Cs}$, and $60 \mathrm{Co}$. The relative amounts of these radionuclides identified the grout sheet as experimental injection five.

A portion of the core-drilled sample was mounted for metallographic examination (Fig. 8.20) and found to contain mumerous fragments of shale trapped in the grout. Examination by scanning electron microscopy could not locate the $\mathrm{Sr}, \mathrm{Cr}$, or $\mathrm{Co}$ because of the very low concentration. However, a $\beta-\gamma$ autoradlograph of the sample clearly showed the location of the radionuclides, and more importantly that the radionuclides had not migrated from the grout into the included shale fragments in the 18 years since injection. 
ORNL-PHOTO 2656-82

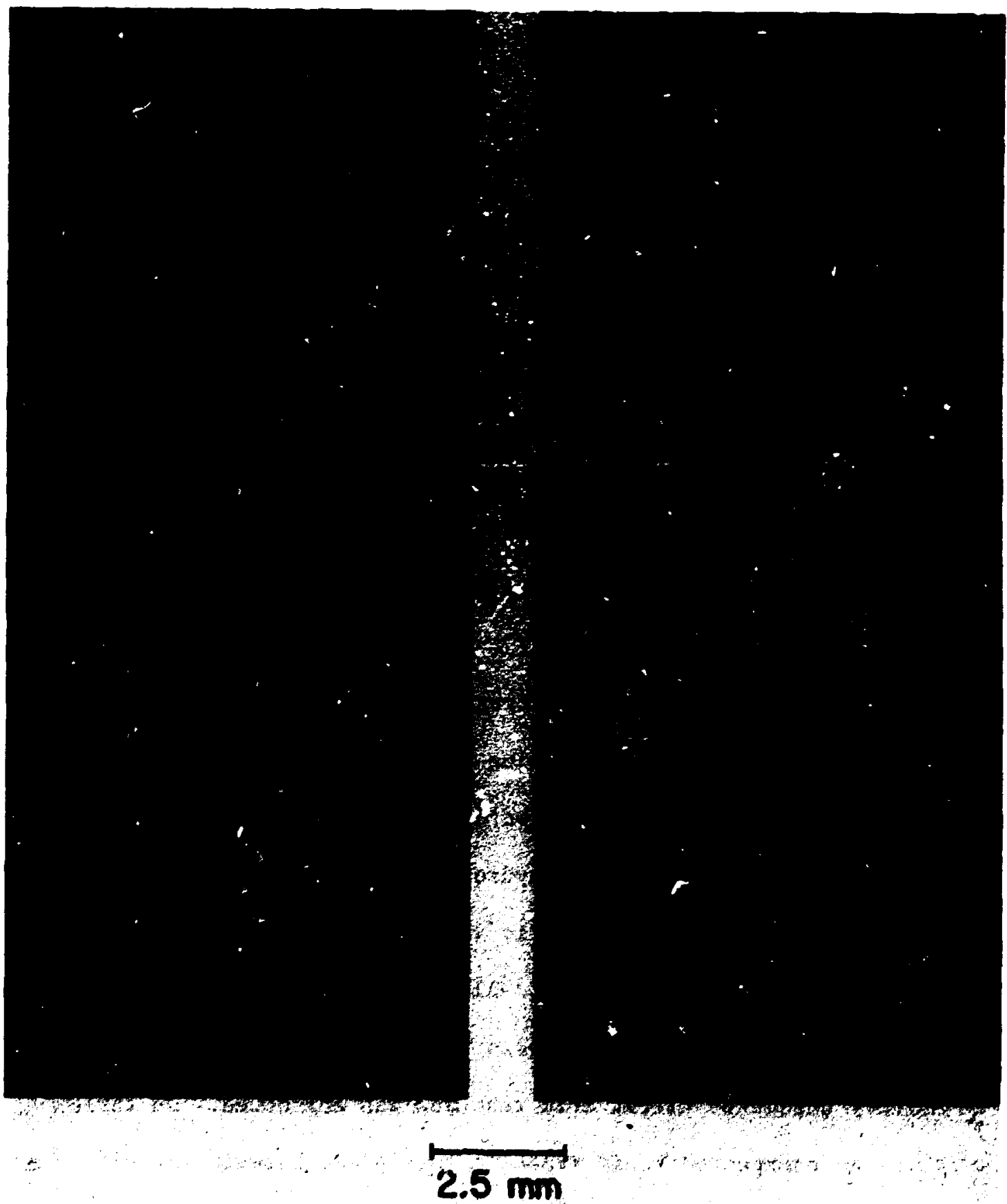

$\beta-\gamma$ AUTORADIOGRAPH

\section{BRIGHT FIELD}

F1g. 8.20. Beta-gamma autograph of cored grout shows no migration of radionuclides. 
8.2.7 Waste Volume Reduction, F. N. Case, J. R. DeVore, T. F. Donaldson, R. W. Haff, S. E. Niorth, J. C. Posey, R. W. Schaich, F. J. Schultz, C. D. Scott, G. W. Strandberg, and J. A. Tompkins

\subsubsection{Dissolution of HFIR Control Plates}

Th1s dissolution of old stored HFIR control plates and their ultimate disposal by hydrofracture is desired to elimfate the storage requirement and to provide space for future change-outs of these control plates.

Two different methods for the dissolution of the aluminum metaleuropium oxide plates were tested successfully. The first method was the direct dissolution of the aluminum and europium oxide in nitric acid using a mercury catalyst. The second method consisted of two steps: first the aluminum was dissolved in sodium hydroxide solution; then, nitric acid was added to convert the aluminum to tne nitrate and to dissolve the europium oxide.

It was shown that the use of iron transfer cans for the control plates is not feasible. The cans containing the plates will be dropped into the dissolution solution. Therefore, both the cans and plates must be soluble. Iron will not dissolve in sodium hydroxide solution. Furthermore, although the 1ron dissolves rapidly in nitric acid, its presence in solution grea $1 \mathrm{y}$ slows the dissolution of aluminum. Aluminum cans should be used.

The use of hydrazine to suppress the formation of nitrogen oxides in the mercury catalyzed nitric acid reaction was abandoned. On three occasions an unexpected rapid reaction took place between the nitric acid and the hydrazine. These reactions were not explosions; they requircd several seconds to go to completion. The very rapid evolution of gas and heat boiled most of the liquid out of the beakers in which the tests were being conducted. On other occasions no reaction was observed even during 
prolonged boiling of the solutions. Rapid fissolution of the aluminum was achieved and observation indicated that zeither $\mathrm{NO}$ or $\mathrm{NO}_{2}$ was produced.

In the best test of the aluminum-nitric acid reaction the initial nitric acid concentration was $5.2 M$ and the mercury concentration was $0.4 \mathrm{~g} / 1$ iter. There were 46 liters of solution per $\mathrm{Kg}$ of aluminum. These values are equivalent to 102 liters of $15.5 \mathrm{M}$ nitric acid and $121 \mathrm{~g}$ of mercury per control plate and aluminum transfer can. The equivalent total volume is 303 liters. This is well below the 1779 liter capacity of the tank in which the reaction will be carried out. Further research may allow some reduction in the reagent requirements.

In this test the mercury catalyst was added to the solution at $64^{\circ} \mathrm{C}$. A very rapid reaction started which quickly heated the solution to boiling, $108^{\circ} \mathrm{C}$. After 9 minutes most of the aluminum had dissolved. The remining part of the sample was floating supported by the bubbles generated on its surface. Only aiter 38 minutes more had the last trace of the sample dissolved. The total time was 47 minutes. All of the very fast reaction, 'oth acid and caustic, followed this pattern. An initial period of very fast reaction was followed by a longer period of slower reaction with a floating aluminum sample.

Mixed rare earth oxides vere added at the beginning of the experiments to simulate the influence of the europium oxide. They dissolved quickly and had no apparent influence on the nitric acid-aluminum reaction.

The reaction of aluminum with $1,2,4$, and $6 M$ sodium hydroxide was investigated. The $6 \mathrm{M}$ solution reacted most rapidly. In this case 20 minutes of very rapit reaction was followed by 33 minutes of slower reaction with a floating sample. The total time for complete dissolution 
was 53 minutes. In the next fastest reaction, $4 M, 75$ minutes was required for complete dissolution.

The acidification of the solution was carried out successfully by the rapid addition of concentrated nitric acid. The heat of the acid-base reaction caused the solution to boil and produced good mixing. When acid was added slowly a gumy precipitate of $\mathrm{Al}(\mathrm{OH})_{3}$ sas first produced. This retissolved with some difficulty. Prolonged digestion might be required in che FPDL reaction tank where no agitation is available, if the procedure of slowly adding acid is followed.

The reagents consumed were as follows: $4.36 \mathrm{Kg}$ of sodium hydroxide per $\mathrm{Kg}$ of aluminum and 17 liters of $15.5 \mathrm{M}$ nitric acid per $\mathrm{Kg}$ of aluminum. The solution volume during dissolution was 18.2 liters per $\mathrm{Kg}$ of aluminum. The corresponding values per control plate are $28.8 \mathrm{Kg}$ of sodium hydroxide and 112 liter 3 of $15.5 \mathrm{M}$ nitric acid. The total volume during dissolution is 120 liters.

Stainless steel test specimens were present during the dissolution tests. The weight losses were determined. The average loss was $1.5 \times 10^{-5} \mathrm{~g} / \mathrm{cm}^{-2}$ during the acid dissolutions. The average weight loss during the caustic dissolution process was $1.9 \times 10^{-5} \mathrm{~g} / \mathrm{cm}^{-2}$. All of this loss took place during the acidification portion of the process.

Each control plate will also contain $1726 \mathrm{~g}$ of cantalum. This metal does not dissolve in either of the processes investigated. Samples of tantalum sheet, $1 \times 1 \times 0.005 \mathrm{in}$, were present during the dissolution tests. No attack of these samples was observed during the acid dissolution tests and only very slight attack was observed during the caustic dissolution tests. Further tests will be made of the dissolution of this material in caustic solution. 
The gaseous products of both reactions could cause problems. The caustic reaction produces hydrogen gas which could cause an explosion hazard. The acid dissolution produces nitrogen oxides' No and $\mathrm{Nu}_{2}$. A peak concentration of about $150 \mathrm{ppm}$ could be reached in the Building 3039 off-gas stack during the initial fast part of the reaction. The nitrogen oxides could be remcved by a scrubbing procedure or by a catalytic reactor similar to those in modern automobile exhaust systems.

The conditions for the reaction of the aluminum control plates with nitric acid were modified so that the reaction can be carried out in existing tankage. The reaction was to be carried out at an acid concentration and mercury catalyst concentration that would give a fast reaction leading to cosplete dissolution in about one hour. An acid concentration of 5.0 to $5.5 \mathrm{M}$ and a mercury concentration of $0.4 \mathrm{~g} / 1$ iter gave these results. The temperature would be controlled by the boiling of the acid. The acid vapor would be condensed in a reflux condenser mounted on the tank and returned to the tank.

The reaction is initially rapid and exothermic. However, calculations indicated that the capacity of the reflux condenser would be exceeded several fold. Furthermore, the required volume of acid would occupy only $a$ sma? I fraction of the tank volume, and because the tank is heated only on the sides by a steam jacket, heating would be ineffective.' Plans to heat the bottom surface with electrical heaters were abandoned because the high radiation background made work in this area infeasible. Both of these problems were solved by using a much laróar volume of more dilute acid. A large fraction of the heat of reaction is used in heating the solution to bolling. When boiling does occur the reaction rate is well past the maximum and the reflux condenser is not overloaded. 
First tests were carried out in beakers heated on a hot plate. Small additions of iron were made to the solutions to simulate the effect of an iron cable used to ower the control plates into the reaction tank. These tests established several facts:

1. The starting time and temperature of the reaction could be controlled by heating the aluminum and acid solution together and then adding the mercury catalyst. A rapid reaction started immediately at temperatures above $60^{\circ} \mathrm{C}$. When the mercury was added before heating the starting temperature varied and was $20^{\circ} \mathrm{C}$ to $30^{\circ} \mathrm{C}$ higher.

2. The initial reaction was rapid but slowed greatly before the sample was completely consumed. The rate can be increased by adding more mercury. The addition of acid is less effective.

Because the heating of the solution by the reaction is a crucial part of the procedure, adequate tests could not be made in a beaker on a hot plate. The rate of hea: loss per unit volume will be much lower for the large tank than for a 1 liter beaker. Consequently, tests were made in a Dewar flask. The heat loss per unit volume was estimated to be similar to that of the 1a: ze canic if the water jacket was not used. The temperature of the reactic measured by a thermometer passing through the stopper of the flask. Id vapor passed through a tube into a graduated cylinder immersed in cold water. The condensate was collected and measured. The results of one of these runs is given in Table 8.6. 
Table 8.6. Reaction of Aluminum with Nitric Acid Under Nearly Adiabatic Conditions ${ }^{a}$

\begin{tabular}{|c|c|c|c|}
\hline $\begin{array}{c}\text { Time interval } \\
\text { (minutes) }\end{array}$ & $\begin{array}{l}\text { Temperature } \\
\text { interval } \\
\left({ }^{\circ} \mathrm{C}\right)\end{array}$ & $\begin{array}{l}\text { Total rate of } \\
\text { heat generation } \\
(B t u / h r)\end{array}$ & $\begin{array}{c}\text { Rate or heat absorption } \\
\text { b) condenser } \\
\left(B t_{u} / h_{r}\right)\end{array}$ \\
\hline $0-3$ & $64.2-66.2$ & $1.9 \times 10^{5}$ & Nil \\
\hline $3-5$ & $66.2-69.2$ & $3.0 \times 10^{5}$ & Nil \\
\hline $5-10$ & $69.3-78.5$ & $3.8 \times 10^{5}$ & Nil \\
\hline $10-20$ & $78.5-92.2$ & $2.8 \times 10^{5}$ & Nil \\
\hline $20-22$ & $92.2-95.2$ & $3.1 \times 10^{5}$ & Nil \\
\hline $22-24$ & $95.2-98.2$ & $3.1 \times 10^{5}$ & Nil \\
\hline $24-30$ & $98.2-102$ & $2.3 \times 10^{5}$ & $8.8 \times 10^{4}$ \\
\hline $30-33$ & $102-102$ & $1.8 \times 10^{5}$ & $1.7 \times 10^{5}$ \\
\hline $33-35$ & $102-102$ & $1.2 \times 10^{5}$ & $1.0 \times 10^{5}$ \\
\hline $35-40$ & $102-102$ & $1.2 \times 10^{5}$ & $1.1 \times 10^{5}$ \\
\hline $40-45^{b}$ & $102-102$ & $1.0 \times 10^{5}$ & $8.0 \times 10^{4}$ \\
\hline $45-50$ & $102-101.4$ & $6.6 \times 10^{4}$ & $5.1 \times 10^{4}$ \\
\hline $50-55$ & $101.4-101.9$ & $8.6 \times 10^{4}$ & $5.1 \times 10^{4}$ \\
\hline $55-60$ & $101.9-102$ & $2.9 \times 10^{4}$ & $3.3 \times 10^{14}$ \\
\hline $60-75$ & $102-101$ & $1.7 \times 10^{4}$ & $2.5 \times 10^{4}$ \\
\hline
\end{tabular}

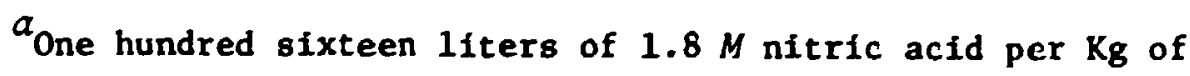
aluminum. The solution also contained $0.88 \mathrm{~g} / 1$ iter of 1 ron and $2.6 \mathrm{~g} / 1$ iter of mixed rare earth oxides. Time zero of the table is the time at which $0.36 \mathrm{~g} / 1$ iter mercury was added.

$b_{0.18}$ g/1iter more mercury was added. 
The rates of heat generation were calculated from the heat capacity of the solution and equipment and the temperature change and from the volume of condensate. No correction was made for the change in heat capacity of the solution as the temperature increased or for the change caused by the reaction of the aluminum and nitric acid. The heat of condensation was assumed to be $540 \mathrm{cal} / \mathrm{g}$. Heat losses from the system were calculated using cooling rate data measured for the system after the completion of the reaction. The rates of heat production have been corrected to the conditions of the full scale reaction. It was assumed that the rate of heat production was proportional to the weight of aluminum present.

The maximum heat load of the reflux condenser is $1.7 \times 10^{5} \mathrm{Btu} / \mathrm{hr}$. This is equal to the estimated capacity of the condenser. The conditions for the reaction are belleved to be approximately correct for the full scale reaction. More exact information cannot be obtained by small scale laboratory experiment. A full scale test should be made if this reaction is used.

More work may be necessary concerning the off-gas. Other investigators report that $\mathrm{H}_{2}, \mathrm{~N}_{2}, \mathrm{~N}_{2} \mathrm{O}$, NO, and $\mathrm{NO}_{2}$ are present in the off-gas. The situation is complicateu further by the fact that $\mathrm{NO}_{2}$ reacts with water to produce nitric acid and NO, and NO reacts with oxygen to produce $\mathrm{NO}_{2}$, but both reactions are comparatively slow. The maximum allowable $\mathrm{NO}_{2}$ concentration in gas released to the atmosphese is $5 \mathrm{ppm}$. The NO w111 oxidize to $\mathrm{NO}_{2}$. The $\mathrm{NO}$ and $\mathrm{NO}_{2}$ will be largely removed by oxidation and scrubbing. If no removal steps are taken and one mole of NO were produced per mole of aluminum, an average concentration of 21 ppm could be present in the off-gas leaving the stack for about 75 minutes once a week. 
The average stoichiometry observed in the laboratory dissolutions was 3.81 moles of nitric acid per mole of aluminum. This is close to 3.75 , which is the value for the reaction producing $\mathrm{N}_{2} \mathrm{O}$, but it is probably the average stoichiometry for several reactions that took place. The heat of reaction calculated from the data used in preparing Table 8.6 was $194 \mathrm{KCal} / \mathrm{mole}$ of aluminum. This falls between the values of 191.2 and $209.3 \mathrm{KCal} / \mathrm{mole}$ for the reactions producing $\mathrm{N}_{2} \mathrm{O}$ and No respectively. The volume of solution used will be 768 liters. This will fit 437 of the volume of tank to be used for this process. This will be sufficient to allow effective heating using the steam jacket.

The acidity of the solution at the end of the reaction was $0.56 M$, but in production the solution must be diluted to 6921 liters in order to achieve a sufficiently low level of radioactivity for handing in the waste disposal system. After dilution the acid concentration will be $0.06 \mathrm{M}$. This assumes a 3-1/2 year old control plate.

Several tests of the dissolution of tantalum metal in caustic solution were made. Sodium hydroxide concentrations of from 6 to $10 M$ were used at temperatures from 100 to $124^{\circ} \mathrm{C}$. The weight losses were low; 0 to 1.9 $\times 10^{-4} \mathrm{~g} \cdot \mathrm{cm}^{-2} \mathrm{hr}^{-1}$ were observed. The addition of sodium nitrite and sodium nitrate as oxidizing agents caused no increase. Previous tests in acid solutions had shown even less attack. No acceptable method for the dissolution of the tantalum present in the control plates has been found. This metal will accumulate in the bottom of the dissolution tank and can be flushed out with water.

The mercury catalyzed dissolution of control plates in nitric acid has been shown to be feasible and the approximate corditions for use of this 
reaction in existing tankage have been established. More detailed work is not planned until it is decided that the process will be used.

Tests were made of the final steps of the process. The solution from a dissolution tes was diluted and neutralized with sodium hydroxide, and the particle size distribution of the resulting precipitate was determined. The $\mathrm{pH}$ of the solution was measured af ter each of a series of dilutions, with results as given below.

\begin{tabular}{cc}
\hline Degree of dilution & $\mathrm{pH}$ \\
\hline 19 to 1 & 1.20 \\
20 to 1 & 1.55 \\
40 to 1 & 1.87 \\
50 to 1 & 2.00 \\
\hline
\end{tabular}

If this solution had been produced by the dissclution af a 3.5 year old plate, a 41-fold dilution would have been required to reduce the radionuclide content to $2 \mathrm{Ci} / \mathrm{gal}$. The solution inftially contained $7.9 \mathrm{~g} / 1$ iter of aluminum, $0.82 \mathrm{~g} /$ liter of iron, and 0.64 molesiliter of hydroger. fon.

The $\mathrm{pH}$ values are close to those predicted by simple dilution calculations. This indicates that the hydrolysis of the $\mathrm{Al}^{3^{+}} \cdot \mathrm{d} \mathrm{Fe}^{3^{+}}$ions did not make a significant contribuiton to the acidity.

The addition of 37.5 mflliliters of $1 \mathrm{M}$ sodium hydroxide per liter of the diluted solution (50 to 1) caused precipitation and increased the pH to 9.9. The particle size distribution of this precipitate was determined using a Leeds and Northrup MICROTRAC. The results, given in Table 8.7 Indicate that the precipitate could be pumped as a slurry. 
Table 8.?. Particle Size Distribution of Precipitate

\begin{tabular}{cc}
\hline $\begin{array}{c}\text { Particle size range } \\
(\mu \mathrm{m})\end{array}$ & $\begin{array}{c}\text { Percent of particles } \\
\text { falling in range }\end{array}$ \\
\hline $16-22$ & 4.2 \\
$11-16$ & 12.5 \\
$7.8-11$ & 22.2 \\
$5.5-7.8$ & 24.5 \\
$3.9-5.5$ & 18.9 \\
$2.8-3.9$ & 11.7 \\
$<2.8$ & 5.6 \\
\hline
\end{tabular}

A study and estimate report for the facility for the HFIR control plate dissolution and other very high activity wastes was issued in August 1982 by the UCC-ND Engineering Division.

\subsubsection{Electropolishing Decontamination Facility}

An electropolisher and a vibratory finisher were installed at the Fission Product Development Laboratory (FPDL) to decontaminate metallic tools and small equipment for reuse at ORNL facilities or for salvage operations. The reduction in the volume of this type of material presently sent to the ORML burial ground will ald in the conservation of the limited burial ground space available at ORNL.

The construction effort on the installatirs of the electropolisher was completed during the report period. ORNL personnel will complete the final tie-ins during the lst quarter of FY 1983 and operational testing will be initiated in the 2nd quarter of FY 1983.

A vibratory finisher was purchased and installed during FY 1982 for decontamination work. Operational testing of this undt will comuence in - FY 1983. 
Decontanination of contaninated equipment during FY 1982 was Iimited due to a lack of operating funds. Approximately $10,000 \mathrm{~K}_{\mathbf{B}}$ of contaminated lead was cleaned to Health Physics tolerance for remelting, and several Itens of equipwent vere decontaninated for reuse in ORKL facilities.

\subsubsection{Anaerobic Digestion of Cellulosic Materials} and Aninal Vastes

A prelininary process design and cost estimate has been made for a plant for volune reduction of low-level solid radioactive waste generated at ORIL. The process is based on extensions of extsting anaerobic digestion technology and laboratory studies indicating the feasibility of this technology for digestion of the organic portion of low-level solid radioactive waste. The volume reduction factor for this process is expected to be approximately $20: 1$.

The waste to be treated consists of $10,500 \mathrm{ft}^{3} /$ year of uncompacted waste from ORIL and the Blology Division at Y-12. This waste 18 assumed to be segregated by the generators to exclude nondegradable materials. The waste 18 delivered to the plant site in dumsters, where it is manually unloaded and fed to a wet shredder-pulper. Some sorting may be done at this point if necessary. Pulped waste is slirried in a mixing tank to the proper solids concentration for feeding to the digestsr ( 117$)$. The 40,000 gallon digester is batch-fed Jally with 11,600 liters water and $117 \mathrm{Kg}$ waste. An equal amount of digest is removed to a surge tank. Hydraulic residence time in the digester is approximately two weeks, which is expected to produce $80 \%$ degradation of solids to soluble organics plus gas $\left(\mathrm{CO}_{2}\right.$ and $\left.\mathrm{CH}_{4}\right)$. The gas will be vented (and flared if necessary) after paselng through a demleter. The digester 1s malntained at $35-40^{\circ} \mathrm{C}$ wth 
Iive steam and is mildy agitated. Caustic is added automatically to control the $\mathrm{pH}$ at 7 , and saall amounts of nutrients are added to maintain the microorganisa population. Effluent from the digester Is filtered to remove suspended solids and the supernatant is discharged to the ILW collection tanks and evaporator system (11,600 1iters/day). The solids are dried and packaged for burial $(23 \mathrm{~kg} / \mathrm{day})$. The digester tank and associated equipment are housed in a prefabricated steel buildire. It is 11kely that the process can be operated wore efficiently than the conservative basis used for study, which would allow some reductions in equipment size or increased capacity.

Capital cost and operating cost were estimated at the conceptual design level. The capital cost estimate includes $30 \mathrm{z}$ for engineering and an additionai 407 of all itemfed costs including engineering for contingencies. The summary of the capital cost estimate 1s:

Item

Land improvements

Buildings

Special facilities

Outside facilities

Construction total

Engineering

Contingency

Total

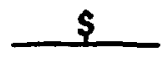

35,000

71,700

320,000

42,600

469,300

140,700

244,000

854,000 
The sumary of the operating cost estimate is:

\begin{tabular}{lrr}
\multicolumn{1}{c}{ Iten } & \multicolumn{1}{c}{} & $\frac{\$ / \mathrm{ft}^{3}}{}$ \\
\cline { 2 - 2 } Direct labor & 56,000 & 5.33 \\
Support labor and materials & 11,000 & 1.10 \\
Worked materials & 6,600 & 0.63 \\
Administrative and clerical & 5,600 & 0.53 \\
Duration materials & 1,400 & 0.13 \\
Total & 80,600 & 7.72
\end{tabular}

These costs are comparable with costs for compaction, and are significantly less than the costs for incineration.

A small 70 liter digester has been ordered to continue process development work and to generate liquid and solid effluents for character:zation and disposal studies in FY 1983. 


\subsubsection{Central Waste Disposal Facility Design and Developeent (B. A. Hannaford, L. H. StInton, and J. H. Chandler)}

This altiyear progran 18 designed to provide a factlity for disposal of low-level solld radioactive saste (LLSR) for all three DOB Oak RIdge plants. The complex geology and hydrology of the DOB Oak RIdge reservation require that extensive site characterization work be carried out in order to quallfy a site under DOE site selection criterfa. A single large area on West Chestnut Ridge, near ORHL, was selected as the reference site. Prelininary field studies (geological, hydrological, and selsnic refraction) were completed on six topographically attractive tracts. As a result of these studies, a decision was wade to continue exanining this site with wore detalled field studies. Because the reference site could not yet be accepted with a high degree of confidence, however, a decision was made to select an additional, alternative site, on which to begin preilninary fleld studies.

For ORIL, the central waste facility will complement SWSA 7, the solld waste storage area belng developed for low-volune, higher-activity solld waste.

\subsubsection{Long-Range Planning for LLSRH Management With1n the Oak Ridge Reservation}

An anaigsis of the current status of Oak Ridge solid waste facilities was prepared for the UCC-ND Waste DIsposal steering Comittee during FY 1982. The results of that study which pertain to low-level solfd radfoactive waste are summarized in Table 8.8. This showed that low-level radloactive waste represented the principal concern because only about 8 years capacity remained for this category of waste, and 
Table 8.8. Status of LLSRU Disposal Pacilities for DOE Oak RT.dge Plants

\begin{tabular}{|c|c|c|c|}
\hline & ORnL & $Y-12$ & ORGDP \\
\hline Exieting factlity & SWSA 6 & Bear Creek Valley & None ${ }^{a}$ \\
\hline Generation rate, $\mathrm{ft}^{3} / \mathrm{gr}$ & 55,000 & 200,000 & 10,000 \\
\hline Regulatory status & Questionableb & Questionableb,c & $\mathbf{H} / \mathbf{A}$ \\
\hline Remaining capacity, yr & $8-10 d$ & $\mathbf{0 0}$ & $\mathbf{H} / \mathbf{A}$ \\
\hline $\begin{array}{l}\text { Lead tire to spen new } \\
\text { factilty, yr }\end{array}$ & $\sim 8$ & $\sim 8$ & $\mathbf{N} / \mathbf{A}$ \\
\hline
\end{tabular}

aORGDP sends unclassified waste to $Y-12$ ( $\alpha$ waste) ard $X-10$ ( $\beta-\gamma$ waste) for disposal.

Concerned with proximity to water table.

CQuestionable compliance with non-DOE regulations.

dDevelopment of SUSA 7 to extend the capacity of SUSA 6 would add an additional 6-8 yr. 
that about 8 years lead tine is required in order to open an facility. In addition, the exdsting OML and I-12 burial grounds were Judged to be in questionable cospliance with regulations because of proxdnity of the waste to the water table.

For low-level radloactive waste, the atudy recomended the development of a central factlity. The centralized concept was recomen.ted on the basis that it fininizes the asount of land set asde for disposal, the site development costs (site characterization, pathways analysis, EIS, site woltoring), tctel capital costs, and operating costs - as compared wth separate facilities for the three plants.

Another alternative which was discarded was comercial disposql. Comercial disposal costs were uncertain, but were 1ikely to be in the range of $\$ 20$ to $\$ 40$ per cublc foot lncluding costs of transportation, contalners, and manifesting. A cost study by OCC-ID Bnglneering for disposal at a site on West Chestnut Ridge produced estinated costs ranging from about $\$ 5$ to $\$ 10$ per cublc foot, with uo provisions for contingency, profit or closure allowances.

\subsubsection{Hest Chestnut Ridge Site Characterization Studies}

From a set, of candidate s1tes which had been Identified in a 1980 study, a single large area on West Chestnut Ridge was selected as the reference site for disposal of radioactive Wh. The favorable characterlstics of the Knox residuum on Chestnut Ridge Included its upland location, considerable depth to groundwater, and good so11 thickness. Portions of the site which wet the requirenent for lese than $20 \%$ slope were then Identifled for wore detalled study (F1g. 8.21). 


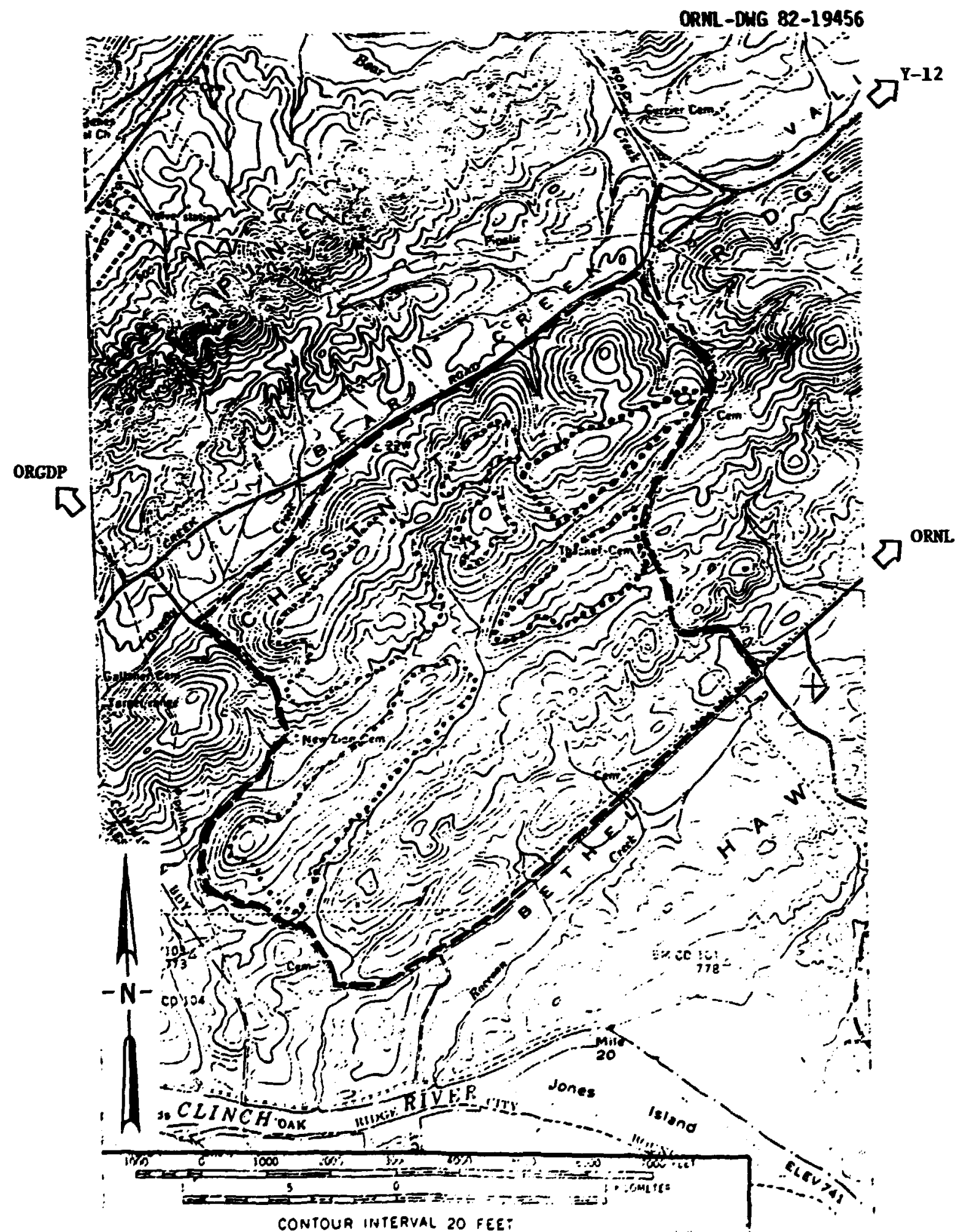

P1g. 8.21. Location and topography of the Hest Chestnut Ridge reference site for a central LLW disposal facility. Tracts witin the dotted Iines represent areas of Knox residuum having 1 ess than 20\% slope; the largest tracts contain $90-100$ acres. D1rections to nearby DOE plants are indicated. 
In terms of DOB siting criterla, the West Chestnut Ridge site characteristics which present the greatest uncertainty are (1) the potential geologic hazard constituted by the karst conditions and (2) the complexity of the site hydrogeologic systen. The characteristics are interactive and both result from chenical weathering of the soluble dolont te bedrock.

8.2.8.2.1 Prelininary Investigations. Several Investigations were carrled out to characterize the site in a prelininary way. The investigations were centered on geologic techniques; supporting studies were done in hydrology and selsaic refraction. These efforts provided the documentation on which to plan wore detalled Investigations which would evaluate the risk posed by the observed karst features.

The preliminary geologic Investigations (8.8) on West Chestnut Ridge generally described the surface expression of karst features - roughly defined as potential sinkholes. These results were to provide part of the foundation for a later drilling progran which would determine the approximate extent of subsurface karst features, such as solution cavit1es.

In order to assess the amount of overburden avallable for shallowland birlal, a selsmic -efraction survey (8.10) was carried out. Reported results showed that ample overburden exists on all six tracts. Selsmograms for 16 locatlons showed that depth to bedrock varied from about 50 ft on lower slopes to over $120 \mathrm{ft}$ near the higher ridges, with depths of about $75 \mathrm{ft}$ or more generally avallable along the ridge crests.

Hydrogeological characterization of the West Chestnut Ridge site was carrled out at two levels. Intetal studies (8.8) was 1dentifled streams, 
springs, and surface runoff features and noted the strong Influence of the karst features on the hydrogeology. A absequent hydrology study (8.12) employed temporary veirs at seven sites in order to measure surface water flow rates to be used as a basis for selection of permanent wontoring sites. Based upon prellainary results, a single locatlon for a permanent flow monitor was recomended. Bunoff fron the eastern portion of the site was very ach lower than fron the western portion; a tentative recomendation was ade that a second permanent monitor be Installed in order to provide better water balance data for the eastern sub-catchments. Design of the first onitor was Inftiated; the design wil employ a flume element in order to provide the desired rangability of approxinately 1 1ps to 4000 1ps. Regular meagurements of runoff were continued st the temporary stations.

\subsection{Study Plan for Thase I Site Characterization}

Investigation. A study plan (8.13) based on the preliminary site investigations was written to serve as the basis for wre detalled studies of the site. These studies wil be performed in a sequence with each phase based on the results of preceding work. The objectives are (1) to determine the three-dimensional extent of the 8011 zone above the water table and bedrock surfaces, (2) determine the existence of extensive bedrock solution cavitles beneath the site, and (3) Iniclate the water balance study for the site.

\subsection{Advisory Subcomitctee Activitie3. A Low-Level Haste} Disposal Site Characterization Advisory Subcommittee was formed by T. H. Row, Chalrman of the Waste Disposal Steering Commlttee (WDSC) for 
UCC-ND. The subconittee, conposed largely of geologists from ORGDP, ORNL and Y-12, was charged with advising WSC on the use of the Knox formation on West Chestmit RIdge for LW disposal. The Subconittee monitored the field investigations, consulted with outside geologists and sumarized their recomendations in an FI 1982 report (8.14).

\subsubsection{Progran Planning for the Central Pacility}

Planned actifities for the new fiscal year generally reflected the results of site characterization reports $(8.8-8.14)$ and called for carrying out a progran of drilling, soll sempling, and hydrological studies on the wore pronising tracts of the West Chestmut Ridge site. Scoping pathways analysis would be performed and compared with the releases allowed under DOE 5820. An alternative site vould be selected for preIIminary investigation, as a hedge against the possible rejection of the West Chestnut Ridge site. 


\subsubsection{Metal Haste Management at ORO Sites (L. C. WHllams)}

Approximately 80,000 metric tons of uranium-contaminated scrap metal Is currently stockpiled at USDOE uranium enrichment facilities in OhIo, Kentucky, and Tennessee. The program sbjective for the past year has been to make assessments of varfous disposal and reclamation options available for elfminating this scrap. The most promising process to date is size reduction followed by melting the metal, then casting the metal into block form for storage or use within the government. An additional benefit resulting from melting is that the bulk of the metal can be readily decontaminated during the smelting process. It is unlikely that commercial resale of the amelted metal will be permitted, but investigatIons have shown that an In-house need does exist for large quantitles of metals in forms that can be easily produced. The current approach toward elimination of the contaminated metal scrapyards is by use of commercial operators for complete processing of the existing scrap metal at the various enrichent facility sites. Commercial operators will be contracted to do on-site segregation and size reduction of the metal. Smelting of the metal by commercial foundry firms may be completed either on- or off-site. The first phase of ecrap processing will begin In early FY 1983 at the ORGDP, then expanded to the Paducah, Kentucky, and Portemouth, Ohio, sites.

The major activities of the Metal Waste Management Program during FY 1982 were as follows: 


\subsubsection{Conceptual Design Requirenents (CDR), Metal Smelting Facility}

The CDR for the Metal Sinelting Facility was completed by Lockwood-Greene Engineers. Inc. Construction, engineering, equipnent, and installation costs were estinated at \$13M with an annual \$2.5M operating cost. The facility was designed for a through-put of 10,000 tons/y. Since the Metal Smelting Facility was not submitted as a FY 1984 line item, no follow-up action has been taken.

\section{9.2 Evaluation of Disposal Options for the ORGDP Contaminated Scrap Metal}

Fluor Enginenrs and Constructors, Inc., completed an evaluation of various disposal options for the ORGDP scrap. "'its study was completed in conjunction with the CDR for the Metal Smelting Factlity. The disposal options investigated by Fluor included (1) burlal of ecrap "as $1 \mathrm{~s}^{\prime \prime},(2)$ burlal of the scrap with varfous modes of size reduction, (3) size reduction and shipment to a smelter facility at either Paducah, Kentucky, or Portsmouth, Ohio. Cost profections of these options are as follows:

$$
\begin{array}{ll}
\text { Burial "as 18" } & 470 \\
\text { Burfal - manual size reduction } & 600 \\
\text { Burfal - semiautomated size reduction } & 575 \\
\text { Burfal - fully automated size reduction } & 375 \\
\text { Fully automated size reduction, then shipment } & \\
\hline \text { to Paducah or Port mouth for final processing } & 350
\end{array}
$$


The cost per ton shown Includes capital equipaent, operating, transportation, and burial ground costs.

\subsubsection{Harket Analysis for the Use of Snelted Steel}

Foundry Design Conpany of Port Lee, New Jersey, was contracted to perform a wiket analysis within the governent to deternine gotsntial usage of steel produced from selting of the contaninated acrap. This study revealed a potential need of 300,000 to 400,000 tons of steel for shlelding purposes through 1992. The jor user of the steel would be accelerator and fusion reactor facilities.

\subsubsection{Comerclal Interest for Processing Contaninated Scrap Metal}

Foundry Design Company of Port Lee, New Jersey, was contracted to investigate the comercial interest in processing the ORGDP acrap. The processing by a comerclal firm would ir-lude on-site scrap sorting and size reduction, then melting of the metal into block form that would be usable for shielding applications. Both on-site and off-site smelting of the ecrap is currently being considered. Preliminary estiwates Indicate an average cost of $\$ 55$ per ton on-site orting and size reduction. Smelting and casting blocks on-site is projected to run $\$ 250$ to $\$ 300$ per ton with off-site amelting estimated at $\$ 450$ to $\$ 600$ per ton. Contacts wth the commerclal firms will proceed during FY 1983 with a projected start of the corting and size-reduction operations beginning during the third quarter of FY 1983. 
8.2.10 Traffic Hanagers Support (D. S. Joy, L. B. Shappert, P. E. Johnson, C. S. Fore, and M. J. Flelden)

The ajor purpose of the Traffic Hanagers Support Progran 18 to convert research and development transportation related computer programs Into operational tools for the DOE traffic anagers. The progran was Inttiated In Karch 1982. The a jor phases of this project Include Legislative Data Base wodifications and application of the routing wodels in energency response.

The scope of the Leglelative Data Base has been expanded to Include operational restrictions wich apply to hazardous wastes in addition to radioactive aterials. A new data bese, Transportation of Hazardous Materials: Directory of Princlpal Contacts, ws developed. By the end of FI 1982, this data base consisted of 568 entries from 32 different states designating those agencles (or personnel) that need to be contacted under particular conditlons by a shipper prior to his movenent of radioactive merial. Also included are esergency response contacts throughout each state. Over 500 requests for Inforwation In the DHrectory of Principal contacts have been recelved and answered.

The HIGHAY routing wodel data base, purchased Initlally In 1979, was expanded to include the location of principal DOE sites, nuclear reactor stes, and approximately 500 major alrports. A separate alport data base was established contalning runway information for the alrports Identifled in the HIGHWI data base which Includes: rumay length, runway width, ruway composition, weight bearing capacity as a function of type of afrcraft landing gear, runway lighting and Instrument approach capabilities. 
In order to respond to an Incident Inwolving radioactive aterials, it ay be necessary to transport trained personnel and/or specialized equipnent to the site of the incident. An airport locator progran was developed wich, when queried, H11 $118 \mathrm{st}$ the airports closest to any site Identified in the HIGHuY routing odel. Several constraints can be Included in the search which would automatically exclude those airports not having the requested ch cacteristics. The characteristics which can be specified Include: ginimue runway length, Instrunent landing capability, and weight of aircraft.

Draft reports of a users' manul for both the HIGHAY routing model and the airport locator program were prepared and subnitted for review. 


\subsection{PUBLICATIONS}

J. D. Sease, E. M. King, J. H. Coobs, T. H. Row, "ORRL Radioactive Waste Operations," Pp. 133-43 in Waste Kanagenent '82, Vo1. II, Proceedings of the Symosiun on Uaste Menagenent at Tucson, Arizona, Harch 8-11, 1982, ed. Roy G. Post, Arizona Board of Regents, 1982.

H. O. Heeren, J. H. Coobs, C. S. Haase, R. J. Sm, and T. Tamara. Disposal of Radioactive Wastes by Hydraulic Practuring, ORu/CF-81/245 (May 1982).

J. M. Chandler, R. P. Milford, B. D. Pletrzak, and S. P. du Hont A Comparison of Costs for Treatment and Storage or Disposal of LowLevel Solid Radioactive Hastes at ORN, ORNL/TM-8092 (Hay 1982).

Evaluation Research Corp., Oak Ridge, TN, History of Disposa: of Radioactive Wastes into the Ground at Oak Ridge National Laboratory, SxNL/CF-82/202 (June 1982).

B. M. Elsenhower, T. H. Jakes, J. H. Coobs, and D. W. Weeter, Current Waste Management Practices and Operations at Oak Ridge National Laboratory - 1982, ORNL-5917 (September 1982).

C. S. Haase, (in press) "Geological and petrological consideration relevant to the disposal of radioactive waste by hydraulic fracturing: An example of the U. S. Department of Energy's Oak Ridge National Laboratory," D. G. Brookins, ed. Proc. of the 6th International Symposiun on he Sclentiflc Basis for Nuclear Haste Management.

D. D. Huff, N. D. Farrow, and J. R. Jones, 1982. "Hydrologic Factors and ${ }^{90}$ Sr Transport: A Case Study." Environ, Geol. Vol, 4(1): 
D. D. Euff, 1982. "Hydrologic Factors and ${ }^{90} \mathrm{Sr}$ Transport of a Low-level Waste Disposal Site." In R. G. Post (ed.) Proceedings of the Sypogine on Maste Hanngent at Tucson, Arizona. Warch 8-11, 1982. Vo1. II, p. 349-356.

B. W. HeDantel, H. T. Korgan, J. G. Koore, H. B. Devaney, and I. R. Dole, Strontion Leachability of Hydrofracture Grouts for SludgeSlurrieg, ORu/Mt-8198, Oak Bidge Mational Laboratory (Harch 1982.)

B. U. NeDaniel, J. G. Koore, "Rheological Characterization of Cenentitious Grouts Used to Dispose of Intermediate-Level Radioactive Waste by Hydrofracturing at Oak Ridge Mational Laboratory," Proceedings of the 4th Syeposin on the Scientific Basis for Huclear Haste Managenent, ha:j at Boston, Massachusetts, Hovember 16-19, 1981.

Lockwood-Greene Bngineers, Final C. D. R. Hetal Seelting Facility, Departwent of Energy, Oak Ridge, TN, Project Order 27, Task 01 (June 1982).

Flour Engineers and Constructors, Evaluation of Diejosal Options for Contaninated Scrap Metal Located at the Oak Ridge Gagecus Diffusion Plant, ORIL/NFW-82/11 (June 1982).

Foundry Design Company, Market Analysis and Facility Modification, Metal Smelting Facillty, Contract No. 62X-04174V (July 1982). Foundry Desisn Company, Comerclal Interest for Proceeding of LowContaminated Scrap Metal Located at the Oak Ridge, Tennessee, Uranfum Bnrichment Facility, Contract No. 12X-43121V (October 1982). 


\subsection{REFERENCES}

8.1 A. H. Stueber, D. S. Huff, M. D. Parrow, J. R. Jones, and I. L. Lunro, 1981. An Evaluation of Some ${ }^{90} \mathrm{Sr}$ Sources in the White Oak Creek Drainage Basin.

8.2 D. D. Huff, N. D. Farrow, and J. R. Jones, 1982. "Hydrologic Factors and ${ }^{90}$ Sr Transport: A Case Study." Envirom. Geol. Vo1. $4(1)$.

8.3 A. H. Stueber, D. A. Hebster, I. L. Kunro, N. D. Rarrow and I. G. Scott. 1981. An Investigation of Radionuclide Releases from Solld Waste Disposal Area 3, Oak RIdge National Laboratory. ORML/TM-7323. Enviromental Sciences DIvision Publication No. 1530. Oak Ridze National Laboratory, Oak Ridge, Tennessee. 53 pP. (Abstract): Geol. Soc. Am. Abstracts with Programs, Vol. 13, no. 1, p. 8.

8.4 J. A. Replogle, 1975. "Critical-Flow with Complex Cross Section." Proceedings of the ASCE Irrigation and Drainage Division Spectalty Conference, August 13-15, 1975, Logan, Utah. p. 366-388.

8.5 K. O. Hasson, and C. S. Haase, 1982. "Stratigraphy of the Conazauga Group (Middle and Upper Cambrian) In the Valley and RIdge Province of East Tennessee" (Abstract): Geol. Soc. Am. Abstracts with Programs, Vol. 14, Nos, 1-2, p. 24.

8.6 J. Rodgers, 1953. Geologic map of Rast Tennessee with explanatory test: Tennessee Geol. Surv. Bull. v. 58, no. 2, 168p.

8.7 J. R. Markello, and J. F. Read, 1981. "Carbonate Ramp-to-Deeper Shale Shelf Transitions of an Upper Cambrlan Intrashelf Basin, Nolichucky Formatinn, Southwest Virginia Appalachians : Sedimentolog," Vo1. 28, p. 57-597.5. 
8.8 C. S. Haase, and N. D. Vaughan, 1981. "Stratigraphy and Lithology of the Conasauga Groups in the Vicinity of Oak Ridge, Ternessee," (Abstract) Geol. Soc. Am. Abstracts with Programs 13 (1):8.

8.9 W. D. Simpson, Principal Fngineer. "Study and Estimate for Very High Activity Waste Handling Facility", UCC-ND Engineering Division, X-0E-191, July 30, 1982 .

8.10 R. H. Kettelle, Report on Preliminary Site Characcerization of the West Chestnut Ridge Site, ORNL/NFW-82/21 (November 1982).

8.11 W. P. Staub, Seismic Refraction Study of the West Chestnut Ridge Site, ORNL/NFW-82/26 (in preparation).

8.12 D. Huff, J. Elmore, and D. Farmer, Hydrologic Study and Evaluation of Ish Creek Watershed (West Chestnut Ridge Proposed Disposal Site). ORNL/NFW-82/27 (in preparation).

8.13 R. H. Ketelle, Study Plan for Phase I Site Characterization Investigation on the West Chestnut Ridge Site, ORNL/NFW-82/22 (in preparation).

8.14 W. E. Manrod III, Chairman, Low-Level Waste Disposal Site Characterization Advisory Subcomittee Report - Fiscal Year 1982, ORNL/NFW-82/28 (in preparation). 


\section{TRANSPORTATION PROGRAM}

\subsection{INTRODUCTION}

The major objectives of the Defense Waste Transportation studies were addressed in a number of topics, Including the legislative and regulatory Inforwation system, DOE support on the next international symposium on tire topic of transportation, transportation criticality support activities, reglonalized population assessments of highway routes, and TRUPACT testing suport.

\subsection{PROGRESS}

Technical progress for eanh of the tasks of this program for this flscal year fust ended follows.

9.2.1 Defense Waste Transportation Studies (L. B. Shappert, D. S. Joy, G. E. Whitesides, C. S. Pore, and N. P. Knox)

The original Legislative and Regulatory Information system was developed several years ago to maintain up-to-date information primarily on state and local legislative actions which could affect the movement of radioactive materials throughout the U.S. Recently the contents of the system were divided into a current and a historical data base, both of which were updated and maintained continuously throughout FY 1982.

Approximately 400 new bills were Identified and status changes were made on hundreds more as the information was recelved. These two data bases were converted to a new data management system, INQUIRE, which will provide an Improved means of data retrieval. To summary papers were written and submitted to the Seventh International Symposium on Packaging and Transportation of Pastoactive Materials (PATRAM '83). Work was inftlated on complling a draft users' manual for accessing the Legislative and Regulatory Information System. Over 
200 requests for Information from the systea were recelved, processed, and answered.

The Seventh International Symposium on Packaging and Transportation of Radioactive Materials (PATRAM '83) has been organized under the sponsorship of TTC at Sandia National Laboratory and ORN with the approval of DOE headquarters. All hotel arrangements have been coapleted and the meetIng, will be held In May 1983 In New Orleans, Loulsiana. Authors' Inscructions for preparation of summarles and final papers have been disveloped by ORNL and approved by TTC.

In June 1979, under the aegis of the Auclear Energy Agency (NEA) and Its Committee on the Safety of Nuclear Installa:lons (CSNI), a working group was formed at which member countries expressed interest In exchanging information and experience on various aspects of spent reactor fuel transportation, wth the infilal project to compare results of the application of criticality codes to a transportation problem.

To support this benchmarking of criticality codes on an International scale, a set of standard problems was developed which would permit the systematic evaluation of these codes which might be applied to shipments of spent light water reactor fuel in casks. An ORNL staff member chaired this effort to organize the problems and compare the results. Particlpating countries subitited results of the five maln problems spectfled which were assembled and evaluated in a final report to members of the NEA. 
The success of this exercise can be masured through the results obtained by applying various calculational sethods to heavly shielded spent fuel casks containing a neutron poison and water coolant in the cask cavity. The studles concluded that the Honte Carlo and other transport wethods can give satisfactory results for spent LWR fuel cask criticality calculations. The results also denonstrate that diffusion theory werhods wst be used wth great care.

Review of the proposed revistons to the IARA regulations for the Safe Transport of Radioactive Materials was also completed. The U.S. position concerning the adoption of the British "Q system" and the addition of a crush test were transmitted to the IABA comitee.

A computerized technique to evaluate the distribution of population densities along a transportation route were developed. Approximately 54 routes were generated to check the population density assumptions used in the RADTRAN program at Sandia National Laboratory. A special set of routes was also prepared showing the population density along both highway and rall routes which would likely be used In transporting waste to a repository site.

\subsubsection{TRUPACT Transport System Tests (L. B. Shappert, W. D. Box, J. C. Rose, and J. 0. Hylton)}

The TRUPACT overpack 18 being designed by TTC at Sandia National Laboratory for the shiprent of TRU wastes from storage locations to a repository. It 18 intended that the overpack withstand all tests required of type B packaging. In addition, it 18 desirable for waste packages carried inside the TRUPACT maintain their integrity under severe impact conditions. To develop information on the behavior of 
these wase packages, the entire transport systen (using a Supertiger overpack as a substitute for the TRUPACT overpack) was tested to accident conditions specified in the regulations. ORM personnel helped load and seal the waste contalners prlor to transporting thea to ORN for testing. The transport systen, weighing approxinately $20,000 \mathrm{~kg}$, was twice dropped fron a helght of 9 at the TSF drop test facility. Acceleroneter data recorded during the test were processed and plots of acceleration, velocity, and displacement versus the were produced at ORML and transitted to ITC.

\subsection{PUBLICATIONS}

C. S. Fore, Transportation of Radioactive Materials: The Legislative and Regulatory Informat1on System, ORM/MM-7439 (TTC-0280) (March 1982).

CSNI Working Group, Standard Problem Exerclse on Criticality Codes for Spent Fuel Transport Contalners (PInal Report), CSNI Report No. 71, prepared for the Committee on the Safety of Muclear Installations, Organization for Bconomic Cooperation and Development of the Nuclear Energy Agency, by Oak Rudge National Laboratory

(G. E. Whitesides, ed.), Oak RIdge, TN (May 1982).

\subsection{REFERENCES}

None. 


\title{
10. TRU WASTE MANAGEMENT PROGRAM
}

\author{
W. W. Pitt
}

\subsection{INTRODUCTION}

The Defense TRU Waste Management Program for FY 1982 consisted of four tasks. These tasks and their overall objectives were:

1. FUETAP Concrete Immobilization - determine the technological feasibility and applicability of autoclaved concretes for isolating IRU wastes.

2. Instrumentation Prototype - field test, calibrate, demonstrate, and evaluate a non-destructive assay system for TRU wastes.

3. TRU Waste Certification Program - develop plans and procedures for certifying ORNL TRU wastes.

4. Cementitious Waste Form Development for PREPP - provide assistance to EG\&G Idaho in the development of a concrete formulation for stored TRU wastes.

\subsection{PROGRESS}

Technical progress for FY 1982 of the four tasks in this program follows.

10.2.1 FUFTAF Concrete Immobilization* (L. R. Dole, G. C. Rogers, J. H. Kessler, T. M. G:Iliam, and K. Duncan)

A large amount of alpha-contaminated waste material is generated in the preparation and fabrication of nuclear components. Much of this

*This project is jointly funded by Defense and Commercial Nuclear Waste Programs and is included in both sections of this annual report. 
waste is combustible; the remainder may be metals, salts, sludges, and filters. Immobilizing these wastes in a FUETAP concrete offers advantages that include a waste form wich is compatible with a wide spectrum of materials, has low leachabilicy, and yields a dewatered final product with negligible radiolysis. Laboratory development and evaluation studies were conducted to obtain data for characterizing the technological feasibility and applicability of such concretes for isolating TRU wastes.

The activity in FY 1982 focused on: (1) PNL FUETAP samples, (2) an engineering scale FUETAP block, (3) Rocky Flats waste stream formulations for Building 374 and $741-2$ sludges, and (4) leach testing of the 374 sludge.

\subsubsection{PNL-FUETAP Samples}

GRNL supplied PNL (W. Ross) with both cold and spiked FUETAP specimens, which are to be included in PNL's TRU-waste form evaluation program. Because of a time shortage, the samples were made with preliminary (but acceptable) formulas using simulated sludge provided by PRL. Time constraints did not allow for optimization of the formulas or for differences between simulated and real waste to be investigated.

\subsubsection{Engineering Scale FUETAP Block}

ORNL successfully cured and dewatered a 75-L FUETAP block, which had a porosity of only 14-volume percent, demonstrating this process on an engineering scale.

The 75-L FUETAP monolith $(51 \mathrm{~cm} \times 46 \mathrm{~cm})$ containing 60 wt \% SPI frit was dewatered September 29-30, 1981. This cylinder was dewatered in a 
113.5-L (30 gal) Jrum with only one end exposed. The temperatures and pore pressures of the block were monitored at: (1) the center, (2) $1 / 2$ $R$ frow the center and top, and (3) 1/2 R from the center and $2 R$ from the top.

The oven required 2 hours to reach $250^{\circ} \mathrm{C}$ and after $24 \mathrm{~h}$ the blocks temperatures at the measuring positions were: (1) $185^{\circ} \mathrm{C}$, (2) $176^{\circ} \mathrm{C}$, and (3) $-140-160^{\circ} \mathrm{C}$. The latter yas estinated because the therwocouple leads shorted out. No significant pore pressures weze measured.

After $24 \mathrm{~h}$ in a $250^{\circ} \mathrm{C}$ oven, this $75-\mathrm{L}$ wonolith lost 5.3 wt $Z$ of water, as compared to 6.1 wh 7 loss from the same batch cast in a 4-L block. The initial water in the formula was 7.0 wt $z$, plus an additional 0.6 we $z$ from the frit. Thezefore, 2.3 wt 7 water remained in the monolith. This is an acceptable water content and is comparable to the water content in the FUETAP concrete used in the $\alpha-$ radiolysis experiments. Therefore, no significant radiolysis is expected from FUETAPs with 2.3 wt 7 water.

\subsubsection{Rocky Flat; Waste Stream Formulations}

A cement-based product (Table 10.1) has been developed wich successfully incorporates 40 Z Rocky Flats Building 374 waste with only a $20 \%$ volume increase. This formula's mix properties make it compatible with inexpensive, standard mixers. The curing and dewatering steps represent a fast, simple and low-temperature process. The compressive strength of this product is adequate and improves upon exposure to potential repository environments.

A simple, rapid, low-temperature solidification process for the Rocky Flats Building 374 wate was developed to achieve reduced processing costs and complexity. Previous experience at the ORNL/CCAC has 
Table 10.1. Trial mix number 86

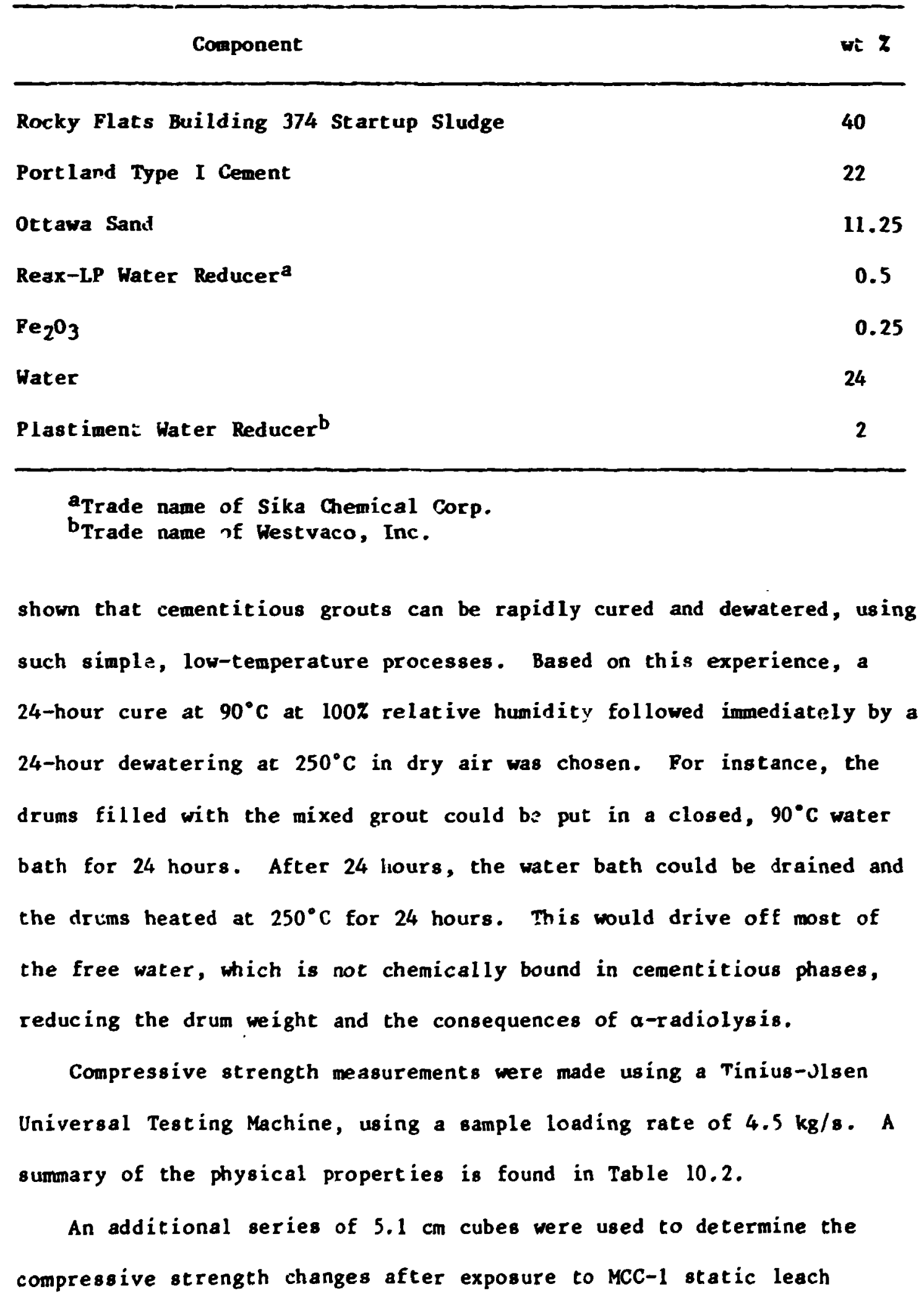


Table 10.2. Bulk Physical Properties of Trial Mix Number 86

Cured Density

Dewatered Density

Porosity

Initial Water/Cement Ratio

Compressive Strength: After Curing

Compressive Strength: After Dewatering
$: \quad 1.75 \mathrm{~g} / \mathrm{cm}^{3}$

$: 1.23 \mathrm{~g} / \mathrm{cm}^{3}$

: 567

$: 1.1$

$: 3.95 \pm 0.16 \mathrm{MPa}$

$: 7.30 \pm 0.24 \mathrm{MPa}$

Final Sample Volume vs. Initial Waste Volume: $-1.2 / 1$

ccnditions. Four replicate specimens were leached in MCC-1 deionized water, silica water and brine for 28 days at $90^{\circ} \mathrm{C}$. In this static leach test, the ratio of leachant volume to sample surface area was approximately $2.3 / 1$.

Afterward leaching, these samples were dried at $250^{\circ} \mathrm{C}$ for 24 hours, cooled, and tested for compressive strength. As shown in Table 10.3, the

Table 10.3. Compressive Strength of Mix 86 Before and After Leaching in MCC-1 Leachants

\begin{tabular}{lcc}
\hline $\begin{array}{c}\text { Leaching } \\
\text { treatment* }\end{array}$ & $\begin{array}{c}\text { Compressive strength } \\
(\mathrm{MPa})\end{array}$ & $\begin{array}{c}\text { \% Increase of compressive } \\
\text { strength after leaching }\end{array}$ \\
\hline $\begin{array}{l}\text { No leaching } \\
28 \text { days in } 90^{\circ} \mathrm{C} \\
\text { deionized water }\end{array}$ & $7.30 \pm 0.24$ & 17 \\
$\begin{array}{c}28 \text { days in } 90^{\circ} \mathrm{C} \\
\text { silica water }\end{array}$ & $8.55 \pm 1.88$ & 13 \\
28 days in $90^{\circ} \mathrm{C}$ & $12.32 \pm 0.78$ & 69 \\
brine
\end{tabular}

*Samples were cured at $90^{\circ} \mathrm{C}$ for $24 \mathrm{~h}$ and dewatered at $250^{\circ} \mathrm{C}$ for $24 \mathrm{~h}$ before leaching and dewatered at $250^{\circ} \mathrm{C}$ for $24 \mathrm{hr}$ after leaching. 
conpressive strengths of these specimens increased after leaching. In the case of the IxC-1 brine, the compressive strength increased by 697 .

ORNL received and disassembled a drum of Rocky Flats 741-2 wastes. This heterogenous material contained the following visually identifiable phases and activities:

\begin{tabular}{llc}
\hline $\begin{array}{c}\text { Drum } \\
\text { fraction }\end{array}$ & Material & $\begin{array}{c}\text { Activity } \\
\mu \mathrm{Ci} / \mathrm{g}\end{array}$ \\
\hline $1 / 4$ & $\begin{array}{l}\text {-Dry brown sugar + wite crystals } \\
\text { - Woist brown sugar with } 20 \mathrm{~cm} \times 0.4 \mathrm{~cm} \\
\text { white blobs } \\
1 / 2\end{array}$ & $\begin{array}{c}100-200 \\
1 / 4\end{array}$ \\
\hline
\end{tabular}

However, once this drum was broken down for glove box experiments funds were not available to do any formulation experiments.

\subsubsection{Leach Studies of Cement-Based Waste Form with Rocky Flats Building 374 Sludge}

Following the MCC-1 guidelines, 29 specimens of Rocky Flats Building 374 sludge in Mix 86 (see Table 10.1) were leached 3-, 7-, 14-, 28-, 56-, and 84-days in distilled water and MCC-1 standard brine at $90^{\circ} \mathrm{C}$. The data were not reduced by the end of the fiscal year and no close-out funds were provided for FY 1983. 
10.2.2 Instrunentation Prototype (P. N. Case, R. H. Haff, and F. J. Schultz)

\subsubsection{TRU Haste Matrix and Isotope Effects Studies}

Ten Neutron Interrogation Assay Systen (NIAS) radionuclide sources

listed below were fabricated at ORML and shipped to the Los Alanos

NatIonal Laboratory.

$\begin{array}{ll}\text { Radionuclide } & \text { Quantity } \\ \text { Curium-244 } & 1 \mathrm{~m} \mathrm{CI} \\ \text { Americium-241 } & 1 \mathrm{~m} \mathrm{CI} \\ \text { Anericium-243 } & 1 \mathrm{~m} \mathrm{C1} \\ \text { Plutonium-242 } & 0.1 \mathrm{~m} \mathrm{CI} \\ \text { Plutonium-240 } & 2.5 \mathrm{mg} \\ \text { Plutonium-239 } & 15 \mathrm{mg} \\ \text { Plutonium-238 } & 10 \mathrm{~m} \mathrm{CI} \\ \text { Neptunium-237 } & 1.42 \mathrm{~g} \\ \text { Uranium-233 } & 20-100 \mathrm{mg} \\ \text { Uranium-235 } & 20 \mathrm{mg}\end{array}$

These sources along with sample drums of known matrices were used in the callbration and determination of sensitivities and detection limits for the neutron Interrogation system. Moderator and absorber characterlstics for the varlous watrices were also studied and correction factors obtained for fissile content assaying of the drums.

Neutron transmission measurements, which wil be useful in elucidating waste matrix effects on both neutron absorption and moderation, were performed on 10 TRU waste drums. The transmission source used was a 0.14 Hg 252 cf sealed calibrated source. 
Eight drums were removed from the TRU Waste Retrievable Storage Facility and shipped to Livi for ise in MAS system calibration and check out.

\subsubsection{Differential Dieaway Neutron Interrogation Assay System}

The LANL neutron Interrogation assay system (NLAS) was received at ORNL on Apri1 1, 1982 (see references 1 and 2 for details of the system). The NIAS can perform the following operations:

1. total spontaneous fission neutron counting (passive interrogation).

2. neutron multiplicity counting for isotope identification (passive interrogation).

3. Induced prompt-fission neutron counting for fissile mass assaying (active interrogation).

The present scheme for neutron assaying the TRU waste drums includes an active interrogation and a total coincidence neutron interrogation for all drums. If, after analysis of the data, any drum cannot be categorized properly a full neutron multiplicity seasurement will be performed. Note that any drum exceeding $5 \times 10^{5}$ neutrons/second total neutron emission rate cannot undergo coincidence or multiplicity measurements in the present system.

An additional flux monttor (a low-pressure $3_{\text {he proportional counter) }}$ was positioned outside the neutron assay cavity opposite the neutron generator. This instrument well measures the neutron output of the generator to ensure that it is a constant value. The measured output varied less than $10 \%$.

Throughput of drums in the active and total coincidence neutrons assay modes (not including neutron multiplicity measurements) was determined. 
It was found that $s 1 x$ to seven drums per hour could be assayed (40-50 drums per 8-hr shift) with sufficient personnel and equipment.

To date, 114 drums have been assayed by the NIAS. The distribution, as of October 1, 1982, of TRU waste druns by neutron enission rate 1s:

\begin{tabular}{lcr}
$\begin{array}{c}\text { Rate of } \\
\begin{array}{c}\text { Neutron Emission } \\
(\mathrm{n} / 8)\end{array}\end{array}$ & $\underline{\text { Druss }}$ & Total \\
\hline$<3 \times 10^{3}$ & 41 & 35.7 \\
$3 \times 10^{3}-5 \times 10^{4}$ & 37 & 32.2 \\
$5 \times 10^{4}-5 \times 10^{5}$ & 22 & 19.1 \\
$>5 \times 10^{5}$ & 14 & 13.0 \\
Total & 114 & 100.0
\end{tabular}

The tentative distribution of TRU waste drums by activity level 13: Activity Concentrations (nC1/g)

No. of Drums

$\ll 10$ 9

$100>$ drums > 10 37

$\sim 100$ 13

$>100$ 55

The drums listed as $\sim 100 \mathrm{nCl} / \mathrm{g}$ may contain less than or greater than 100 $100 \mathrm{nCi} / \mathrm{g}$. Purther fsotopic Investigation 18 required before a definitive answer can be given. 
10.2.3 TRU Waste Certification Progran (W. D. Box, J. D. Sease, E. M. King)

This was a one-year progran and has been essentially completed. All pertinent procedures from the UCC Standard Practice Procedures Manual, the ORNL Health Physics Manual, the Radioactive Sollds Waste Operation Manual, the Code of Pederal Regulations, Quality Assurance Manual, and DHvisional Bullding manals have been assembled into an appendix to the Certification Program.

The first part of the ORNL Certification Program was informally submitted to WIPP In May and was reviewed with very few suggestions for change.

The portion remalning to be completed before final approval of the entire program is the addition of specific passages to the aforementioned procedure manual.

With the addition we hope to certify our first waste by the second quarter of FY 1983. 
10.2.4. Cementitious Haste Form Development for P.REP (L. R. Dole and E. H. KcDaniel)

During FY 1982 the following three subtasks were addressed: (1) waste form formulations studies, (2) INEL PRocessing Experimental Pilot Plant (PREPP) Proof-of-Principle Tests, and (3) review of the Ralph $M$. Parsons (RMP) Company conceptual design of PREPP selection of mixing equipment.

According to the PREPP flow sheet, the incinerator ashes will be separated into a fine and coarse fraction. The coarse material will be shredded metal and noncombustible debris, which will be dumped into 208-L (55 gal) drums. The fine ash fraction $(<1.9 \mathrm{~cm})$ will be mixed with cementitious materials, made into a fluid grout and poured over the drumed coarse debris. This grout is to flow into the interstices, encapsulating and fixing both the PREPP coarse and fine wastes into a durable monolith.

\subsubsection{Formulation Studies}

Workable (easily implaced and resists segration) concrete formulations were prepared with both low noncombustible (high carbon content) and high noncombustible (low carbon content) simulated PREPP waste, as received from INEL. Pour types of waste loadings were used: (1) High NonCombustible (HNC), screened ( $\$ 20 \mathrm{NBS}$ screen) to $\leq 850$ micron particle size; (2) HNC random particle size; (3) Low NonCombustibles (LNC) screened to $\leq 850$ micron particle rize; and (4) Mixture of HNC and LNC screened to $\leq 850$ micron particles. Fata are summarized in Table 10.4 . Using a ASTM I-II LA cement from the IN:L area, workable concrete formulations were prepared with a lower $(0.45)$ water/cement $(w / c)$ ratio than 
Table 10.4. Composition and properties of concrete that contain PREPPa waste

\begin{tabular}{|c|c|c|c|c|}
\hline \multirow[b]{2}{*}{ Material } & \multicolumn{4}{|c|}{ Amcunt (wt $z$ ) } \\
\hline & $\mathbf{1}$ & $\overline{2}$ & $\overline{3}$ & 4 \\
\hline Type I Portland Cemen: & 22.55 & 18.70 & 16.74 & 21.56 \\
\hline ASTM Class F Fly Ash & 19.61 & 16.26 & 14.56 & 18.74 \\
\hline D-65 Water Reducer ${ }^{b}$ & 0.98 & 0.81 & 1.46 & 0.94 \\
\hline $\mathrm{H}_{2} \mathrm{O}$ & 15.69 & 13.01 & 37.12 & 15.00 \\
\hline Haste: HNC ( $<850$ micron) & 41.18 & 34.15 & & 39.36 \\
\hline HNC (large pieces) & & 17.07 & & \\
\hline LNC ( $\leq 850$ micron) & & & 30.57 & 4.40 \\
\hline Density $\left(\mathrm{g} / \mathrm{cm}^{3}\right)$ & 2.23 & 2.17 & 1.54 & 1.95 \\
\hline $\mathrm{W} / \mathrm{C}\left(\mathrm{H}_{2} \mathrm{O} /\right.$ cement $)$ & 0.70 & 0.70 & 2.22 & 0.696 \\
\hline 7d Compressive Strength (MPa) & - & 17.30 & 4.13 & 26.05 \\
\hline & & $\begin{array}{c}(2508 \\
\text { psi) }\end{array}$ & $\begin{array}{l}\text { (602 } \\
\text { psi) }\end{array}$ & $\begin{array}{r}(3777 \\
\text { psi) }\end{array}$ \\
\hline
\end{tabular}

aprocessing experimental pilot plant

bTrade name of Dowe11 Inc.

has been previously reported (0.7). The mix composition is listed in Table 10.5. This mix was thick enough to support three $2 \mathrm{~cm}$ pieces of high noncombustible waste, when they were placed on a $5.1 \mathrm{~cm}$ cube of fresh mix.

\subsubsection{INEL PREPP Proof-of-Principle Tests}

On May 20-21, 1982, a proof-of-principle test was conducted at INEL, EG\&G, Idaho Palls, Idaho, to demonstrate the feasibility of encapsulating shredded metal with incinerator ash in a cement based grout. 
Table 10.5. Composition and properties of concrete that contain PREPPa waste

\begin{tabular}{lc}
\hline \multicolumn{1}{c}{ Material } & Amount (ut $\mathrm{z}$ ) \\
\hline Type I-II LA Cement & 23.67 \\
ASTM Class F Fly Ash & 21.62 \\
Waste - High Noncombustable, $\langle 850$ microns & 42.20 \\
D-65 ${ }^{2} \mathrm{H}_{2} \mathrm{O}$ Reducerb & 0.87 \\
Water & 10.60 \\
\hline Density (g/cm ${ }^{3}$ ) & 2.23 \\
W/C (H20/cement) ratio & .45 \\
Slump & $5-8 \mathrm{~cm}(2-3$ in.) \\
14 d Compressive Strength & $45.0 \mathrm{kPa}(6521 \mathrm{psi})$ \\
\hline
\end{tabular}

aprocessing experimental pilot Plant.

${ }^{b}$ Trade name of Dowell Inc.

The test was in conjunction with the PREPP to be built at INEL, Idaho Falls, Idaho.

Two basic grout formulas, one provided by RMP Company, design engineers for the PREPP facility, and an ORNL formula which contained fly ash and a water reducing agent, were considered for possible use. The RMP formula used no water reducing agent and used sand instead of fly ash. This formula is used in the construction industry and has 2 proven performance record when mixed with inert aggregate. The ORNL formula is similar, but tries to compensate for the uncertain effects of the incinerator ash. Each has a water/cement (w/c) ratio of sbout 0.70 . 
Different types of anixtures are added to concrete (or grout) to modify some of its physical and mechanical properties to make it more workable and/or wore durable. A major function of the ORNL waste form development effort for PREPP was to select, based on past experience, admixtures that would be suitable for use in preparing grouts to fix PREPP waste and to verify performance by laboratory tests.

The first mixes were poured into 19-L (5 gal) cans containing a variety of $>2 \mathrm{~cm}$ BNC particles. Grouts were vibrated around the waste using a construction "stinger" vibrator. In all cases, a slump of 13-15 cm (5-6 in.) was obtained, which is standard for pouring concrete. Five or six mixes were tested in this manner. Even though the grouts had an acceptable slump and no water collected on top, they did not have the right gel properties. Initial set had been achieved within $24 \mathrm{~h}$. Final set was also probably achieved within 24 h (visually determined, not actually measured).

Grouts made with LNC ash tended to be water demanding and had a low slump and poor workability. These grouts required a w/c of approximately 2.0 .

Samples made in 208-L (55 gal) drums were vibrated on a vibrating table. The drums were filled with scrap metal that had been heated to $77^{\circ} \mathrm{C}$, in order to simulate incinerator conditions, and the grout containing the $<2 \mathrm{~cm}$ incinerator ash was poured around the metal. The RMP formula with approximately 35 wt $z$ incinerator ash did not flow well around the metal and had false set. The grout was a dry crumbly material, wich indicated a need for a wetting agent. ORNL recommended that D-65, a Dowell water reducer, be added. Past tests at 
ORNL showed this admixture to be effective in separating the cenent particles and suspending them uniformly in the wix vater. This separation of cement particles resulted in a lubricating effect, as if there were wre free wer to decrease the grout viscosity. Unlike many admixtures, D-65 does not retard set time of the grout, and early set time is required for safest transfer in the PREPP process. Twenty-five wt $z$ D-65 was added to the nix, and the w/c was kept at approximately 0.70 . The slump went to $>30 \mathrm{~cm}(12 \mathrm{in.})$. The grout becane extremely fluid and began to segregate. This mix was added to the first drum since two mixes were required to fill a 208-L (55 gal) drum.

Another mix was made to try to achieve a constant slump of $12.7 \mathrm{~cm}$ (5 in.). The dry solids were added to the mixer; D-65 was dissolved in minimum $\mathrm{H}_{2} \mathrm{O}$ and added slowly as the solids were tumbled in the mixer. A w/c of 0.57 was required to achieve a constant slump of $12.7 \mathrm{~cm}(5 \mathrm{in})$. This grout contained about 35 wt $z$ incinerator ash. The grout was very plastic and workable. Visual tests showed enough air was entrained to provide good freeze-thaw property (This should be verified in the laboratory). A second mix using this formula was prepared to finish filling the second frum. This last grout possessed excellent rheological properties, and should pass the "proof-of-principle test."

\subsubsection{Review of PREPP, the RMP Company Conceptual Design Selection of Mixing Equipment}

Through an existing contract with EGGG, Idaho, ORNL was solicited to evaluate the RMP Company's Study Report for RHMC PREPP Cementing. After reviewing the RMP Company's report, ORNL chose to undertake an independent equipment review of relevant batch equipment. Basically, this 
review defines and applies a well described evaluation procedure by establishing a systematic approach to the numerical scoring of selection criteria against specific performance requirements. It uses the RMP basis and scoring system with some modifications to normalize equipment cosparisons and rationalize the numerical rating (1 to 10 ) of the performance criteria.

10.2.4.3.1. Evaluations. Of the nine performance categories listed by RMP, seven were rated by ORNL by assigning numerical weights ( 1 to 10) to each. The remaining two were evaluated and determined to have little inpact on overall plant operating costs and therefore were not assigned a numerical weighting value. These categories along with their weighting factors are given in Table 10.6. The development status was given the highest weighting (8) and reflects the extent of operational experience with a particular model of mixer. Space requirements and controlled delivery to drums were also rated high because cell construction is the most important cost factor and delivery to the drums is one of the most critical and sensitive phases of the process. Tolerance to mix variation was given a weight of 5 , becalls e fluctuations in the waste stream and their effects on mix rheolo,. in be mitigated by formulation studies. The deconcamination water recycle was given a rating of 6 because ideally the aixing operation should not result in a side stream that requires additional waste volume. The availability and ease of maintenance was given an 8 weighting factor (RMP rating $=6$ ) because they are the keys to cost-effective operation throughout the plant life. The contamination confinement of the mixer was wighted four because other operations such as calcining and screening will determine the size 
Table 10.6. Batch processing equipment rating sheet*

\begin{tabular}{|c|c|c|c|c|c|}
\hline & $\begin{array}{c}\text { Rotary } \\
\text { non-tilt }\end{array}$ & $\begin{array}{l}\text { Rotary } \\
\text { tilt }\end{array}$ & $\begin{array}{l}\text { Vertical } \\
\text { side-out }\end{array}$ & $\begin{array}{c}\text { Vertical } \\
\text { bottom-out }\end{array}$ & $\begin{array}{l}\text { Little ford } \\
\text { horizontal }\end{array}$ \\
\hline Development (8) & 64 & 64 & 48 & 32 & 32 \\
\hline $\begin{array}{l}\text { Mix variation } \\
\text { tolerance (5) }\end{array}$ & 50 & 50 & 20 & 20 & 50 \\
\hline Space required $(8)$ & 32 & 20 & $16 *$ & $16 \star$ & 48 \\
\hline $\begin{array}{l}\text { Contamination } \\
\text { confinement }(4)\end{array}$ & 24 & 8 & 40 & 40 & 32 \\
\hline $\begin{array}{l}\text { Decont amination } \\
\text { water } \\
\text { recycle (6) }\end{array}$ & 48 & 48 & 48 & 48 & 60 \\
\hline $\begin{array}{l}\text { Availability/ } \\
\text { maintenance (6) }\end{array}$ & $48 * *$ & $32 \star \star$ & 48 & 48 & 48 \\
\hline $\begin{array}{l}\text { Controlled } \\
\text { delivery }\end{array}$ & 16 & 16 & 32 & 32 & 32 \\
\hline $\begin{array}{l}\text { Total raw score } \\
\text { (510 maximum) }\end{array}$ & 282 & 238 & 252 & 236 & 302 \\
\hline
\end{tabular}

*ORNL's analysis dropped RMP's equipment cost (3) and power consumption categories and raised the wighted availability and maintenance fror. (6) to 8 . **Normalized to $10 \mathrm{drums} / \mathrm{batch}$ or $20 \mathrm{drums} / \mathrm{day}$ - continuous. ***High maintenance doses from contamination.

of the off-gas cleanup system. ORNL dropped the power consumption category because there is little practical difference between mixers, and this will be an insignificant fraction of the plant load. The equipment costs were also deleted because they were not considered an important impact on the overall plant costs.

The equipment listed on the RMP report and a Littleford mixer Model KFM 3000 were evaluated in the ORNL stidy. The results are listed in Table 10.6. 
10.2.4.3.2. Conclusions. Table 10.6 shows ORH's analysis without RMP's categories of equipment cost and power consumption and with raising the weight of the availability and ease of maintenance from six to eight. This analysis shows about a 107 difference between the Vertical Sideout (252), the Rotary Non-Tilt (282) and the Littleford horizontal (302) mixers. The average score of these three is 280 with a spread of about \pm 28 points. These ratings are close enough to be inconclusive and the relative total scores could be reordered with the development of more accurate evaluations of maintenance requirements, space requirements, and controlled delivery systems. Resources did not allow ORNL to pursue these critical items in sufficient detail.

\subsection{PUBLICATIONS}

None.

10.4 REFERENCES

None. 
C'JMMERCIAL NUCLEAR WASTE MANAGEMENT PROGRAMS 


\section{INTEGRATED DATA BASE PROGRAM}

R. J. Notz

\subsection{INTRODUCTION}

This progran was intlated in FY 1980 for the purpose of establishing and maintaining a computerized, integrated data base of current and projected nuclear wastes in the United States. A consistent set of evaluated information on waste inventories, characteristics, sources, package descriptions, and locations of interim storage and disposal sites is needed by the DOE and other agencles and contractors for use in waste program planning and systems analysis. The data base will also include costs, and will be capable of taking into account the effects of different methods of chemical treatment and packaging on the characteristics of final waste forms.

\subsection{PROGRESS}

Technical progress for each of the tasks of this program for this flscal year just ended follows.

\subsubsection{Integrated Data Base Program (C. W. Alexander, W. L. Carter, C. W. Forsberg, H. W. Godbee, B. M. Horwedel, A. H. K1bbe;, and G. W. Morrison)}

This program is fointly funded by Commercial Naste Management and Defense Waste Management, and 18 carried out in a fully integrated manner. See Section 12 for the Progress, Publications, and References dealing wth this program.

\subsection{PUBLICATIONS}

See Section 12.3

\subsection{REPERENCES}

See Secrton 12.4 . 


\section{HIGH-LEVEL WASTE MANAGEMENT PROGRAM}

W. W. PItt

\subsection{INTRODUCTION}

The Commerclal High-Level Waste Management Program for FY 1982 consisted of three tasks. These tasks and these objectives were as follows:

1. ORNL FIxation of Hastes in Concrete - prepare an evaluation report on PUETAP concrete as an alternative waste form for high-level wastes.

2. High-Level Waste Container Development - conduct final examination of HW canister material and the document study.

3. ORNL So1-Gel Coated Particle Waste Porm Development - document reeilts of work done on sol-gel coated particle waste form for high-level wastes.

\subsection{PROGRESS}

Technical progress for each of the tasks of this program for FY 1982 follows:

11.2.1 ORNL PIxation of Waste in Concrete (L. R. Dole, J. H. Keseler, M. T. Morgan, and G. C. Rogers)

Th1s task was performed as part of the DOE program to evaluate alternative processes to solidify $h i g h-l e v e l$ radioactive wastes and to evaluate the quality of the solid waste product. over the past year, studies have been directed toward characterizing the technological feasibility and applicability of concrete. In particular, FUUTAP concretes (Figure 1) have been developed as alternative waste forms for both defense and commerclal radioactive wastes. This program was terminated at the end of 
ORNL-DWG 81-9507R3

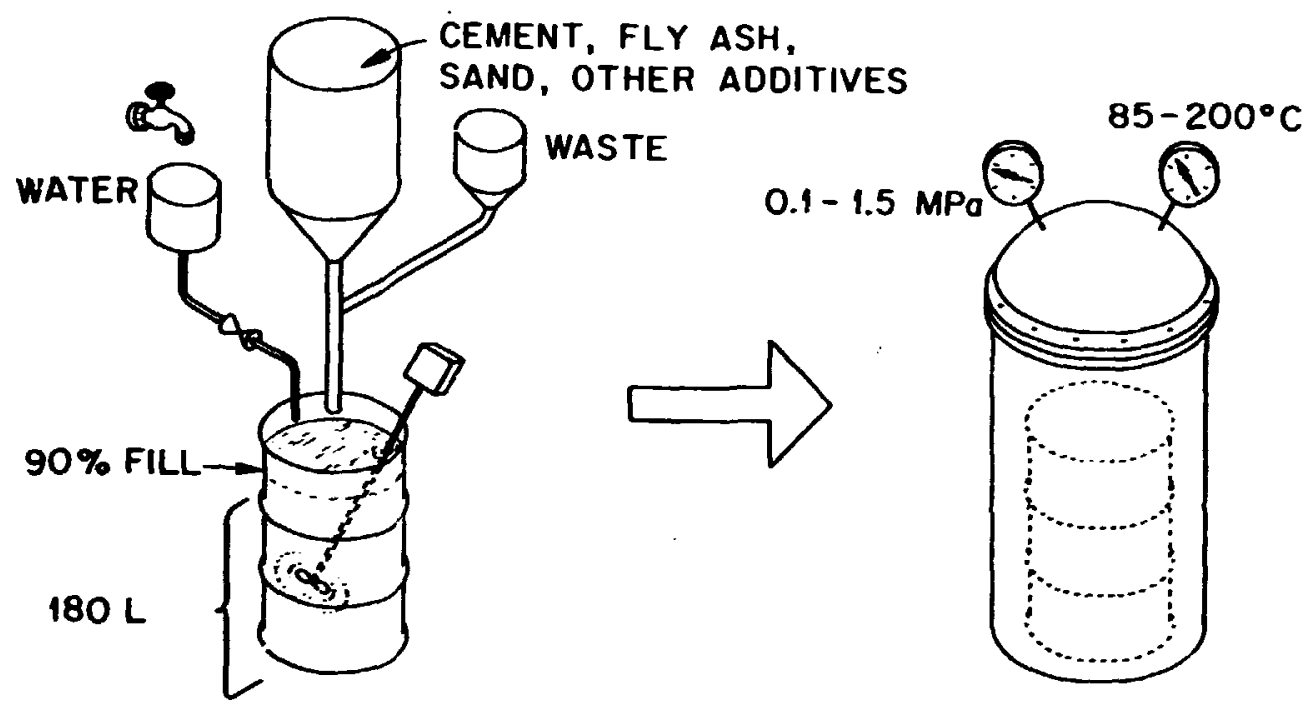

(1) $M I x$

(2) 24-h PRESSURE
CURE

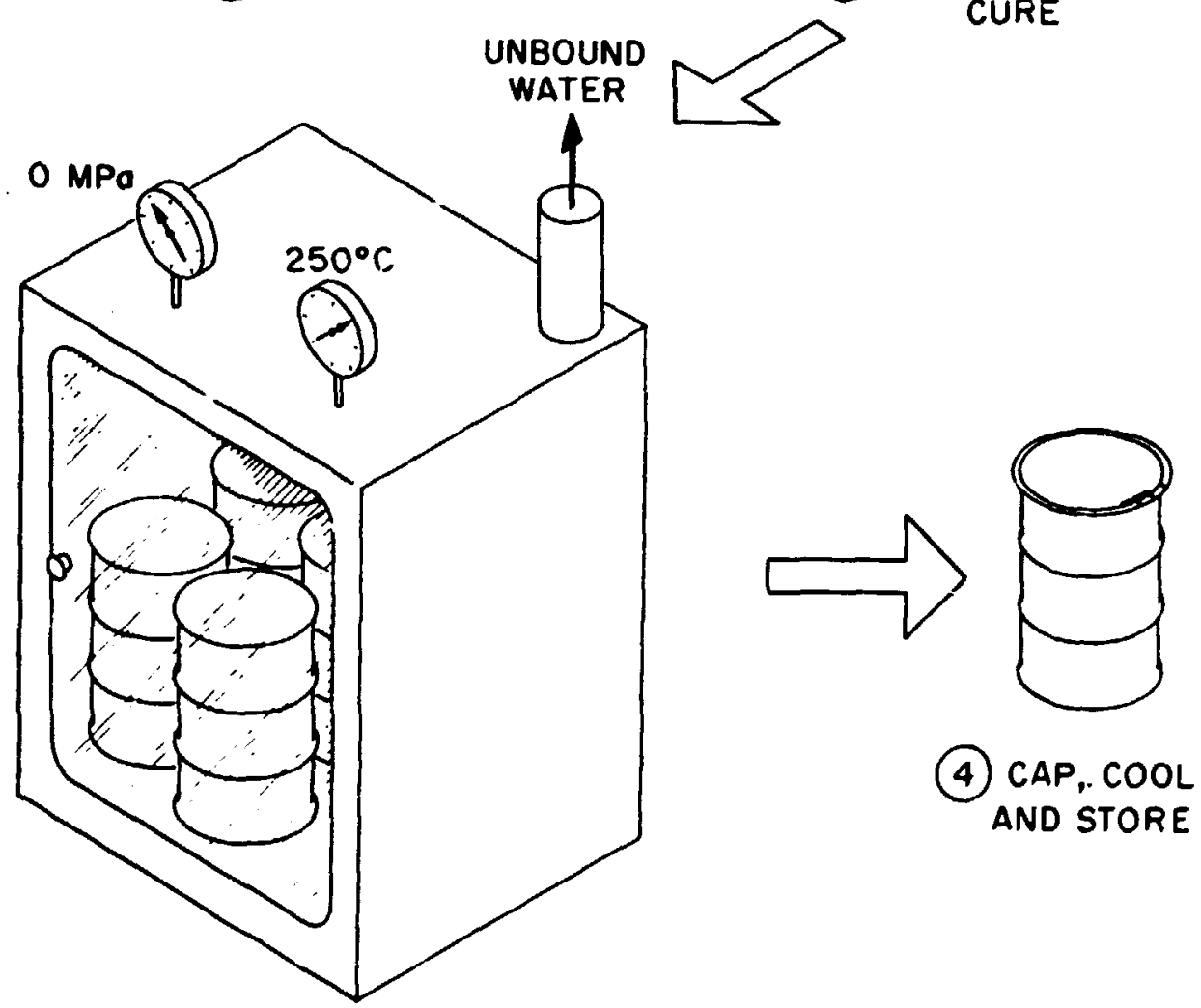

(3) 24-h OVEN DRY

FUETAP FLOW SHEET

F1g. 11.1. Plow sheet for FUETAP concrete developed for the Savannah River Plant high-level defense wates. 
FY 1982 wth the preparation of a draft evaluation report, which w11 be published as ORNL/TM-8579.

The following sections summarize selected topics from this evaluation report.
(1) Processabillty
(2) Radiolytic Stability
(3) ieachability
(4) Thermal Stability
(5) Summary and Conclustons

\subsubsection{Processability of Concrete Waste Hosts}

The processability of FUETAP concretes is a major advantage of this radioactive waste disposal alternative. For example, one of the alternative flow sheets for the SRP defense high-level waste requires that two tons of dry solids be added to a full charge of water and set retarder In a ribbon mixer over two h. To assess the consequences of a broken blender-shaft or a frozen transfer boom, the threshold solids for set, the phase separation and the set-time were investigaced.

Shown below are the threshold solids addition for set, the phase separation and the set-time for the MCC-1 FUETAP formulation wh simulated SRP-HLW defense waste.

These results show that for this process step, no auxiliary agitation, backup transfer system, or extraordinary operational procedures are required to deal wh abnormal events.

\subsubsection{Radiolytic Stability}

The Jong-term $a-r a d 10 l y s i s$ experiments at $25-30^{\circ} \mathrm{C}$ used $10 \mathrm{ml}$ carbon steel capsules, containing FUETAP concrete specimens $(1.5 \phi \mathrm{cm} \times 3.5 \mathrm{~cm}$; 


\begin{tabular}{|c|c|c|c|c|}
\hline $\begin{array}{c}\text { Percent of } \\
\text { total solids } \\
\text { added } \\
\end{array}$ & Set-tIme & $\begin{array}{l}\text { Percent } \\
\text { phase } \\
\text { separation }\end{array}$ & $\begin{array}{c}\text { Volume } \\
\text { of } \\
\text { liquid }\end{array}$ & $\begin{array}{l}\text { Volume } \\
\text { of } \\
\text { solids }\end{array}$ \\
\hline 25 & No set & 43 & $117.0 \mathrm{~cm}^{3}$ & $155.0 \mathrm{~cm}^{3}$ \\
\hline 37.5 & " & 31 & 91.0 & 200.0 \\
\hline 50 & " & 14 & 56.0 & 340.0 \\
\hline 52.5 & " & $<1$ & 3.0 & 365.0 \\
\hline 75. & $<10 \mathrm{~h}$ & 0 & - & 399.0 \\
\hline 87.5 & $4-10 h$ & 0 & - & 412.0 \\
\hline
\end{tabular}

$6.2 \mathrm{cc} ; 8.2 \mathrm{~g}$ sollds) which were spfked with $4.5 \mathrm{mg}$ (tests $1,2,3), 0.5$ mg (tests 4,5) and $1.5 \mathrm{mg}$ (test 6) of curium -244 (12.3 mg per curfe). The dead volume $(\sim 5.8 \mathrm{cc})$ of each test cell was measured by expanding a known volume and pressure of argon into the test capsules. The test's experimental condftions and ara summarized below.

\begin{tabular}{cccc}
$\begin{array}{c}\text { Dewatered } \\
250^{\circ} \mathrm{C}, 24 \mathrm{~h}\end{array}$ & $\begin{array}{c}\text { Dose rate } \\
\text { M rad } / \mathrm{hr}\end{array}$ & $\begin{array}{c}\text { G(total gas) } \\
\text { molec./100 } \mathrm{eV}\end{array}$ & $\begin{array}{c}\text { Dose range } \\
\text { for average } \\
\text { rad }\end{array}$ \\
\hline No & .56 & 0.095 & $.1-7 \times 10^{8}$ \\
Yes & .56 & 0.006 & $1-2 \times 10^{9}$ \\
Yes & .56 & 0.005 & $.01-2 \times 10^{9}$ \\
Yes & .063 & 0.001 & $3.7 \times 10^{8}$ \\
Yes & .19 & 0.002 & $.2-1 \times 10^{9}$ \\
Yes & .19 & 0.008 & $1-5 \times 10^{8}$
\end{tabular}

The conservative total gas $G$ (Molecule/100 ev) values were taken from the averages of the steeper inttial linear pressure rises. These $G$ (total) values are a fifth to a third of Bibler's values.l 
Use of these $G$ values is over conservative, since they were taken from the Intital steep linear portion of the curves. If they had been taken from the flatter region of the Pressure vs. Time curves (Figure 2), the calculated integrated off-gasing would be lower by 3 to 4 fold. Purthermore, actual waste particles would be of sufficlent size to reduce the dose to the concrete matrix two orders of magnitude compared to these specimens which were spiked using a nitric actd solution, giving a homogeneous distribution of Con-244.

Independer: studies have shown that FUETAP concretes can be very effective recombination catalysts. But, these small ( $5 \mathrm{cc})$ samples may have had Insufficient internal diffusion paths for effective recombination; and therefore, there may be a significant sample geometry effect. It is possible that radfolysis measurements on very small specimens could be conservatively high by factors of 10-30x, due to the high escape surface-to-volume ratio.

The combination of these factors could result in an overestimate of radfolysis rates of $3-12,000 x$, if the total gas G-values are used in a simple Iinear model.

Figure 11.1 shows estimates of gas pressurization for non-dewatered and dewatered FUETAP concretes in a perfectly sealed $200 \mathrm{~L}$ drum filled to 90\% capacity. These estimates are made from actual data points and did not use a linear extrapolation of the Initial G-values.

\subsubsection{Leachability}

Using the MCC-1 static leach tests, two PUETAP formulation series, MIX:MCC-I and MIY:MCC-6, were evaluated for the following effects:

a. The effect of substituting slag and fondu cements for Portiund Type I Cement (Table 11.1). 


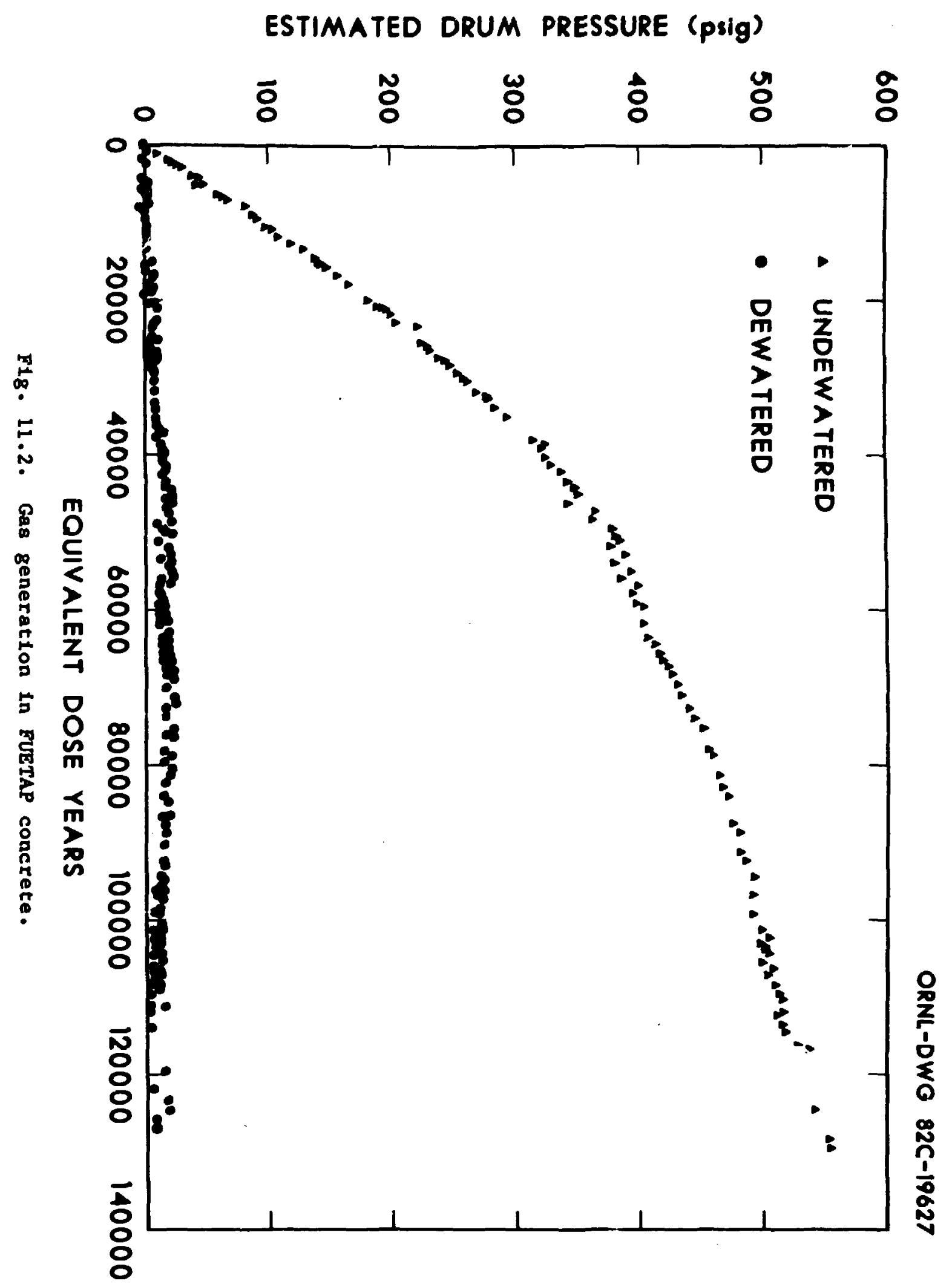


b. The effect of adding sodium bentonite and Indian Red Pottery clay (Table 11.2 and PAgure 11.3).

c. The effects of MCC standard leachants and temperature on Cs, Sr, U, Ce, N tzon a FUETAP MIX: MCC-6 (Table 11.3).

These data (Table 11.1) show that the FUETAP process results in durable product with three readily avallable comercial cements.

Table 11.2 and PIgure 11.3 demonstrate that clay additives reduce the Initial Cs washout and leach rates by about a factor of two.

This effect of Initial washout on the reported HCC-1 leach rates 18 11lustrated In Figure 11.4 using $M C C-190^{\circ} \mathrm{C}$ strontlum leach data. In these cases, the short-term leach rate data reported, as specified in the McC-1 testing procedure, are dominated by wahout and are therefore biased. Because the MCC-1 procedure results in testing specinens with a sample surface-to-volume $(8 / v)$ ratio of $\sim 7$ and the actual waste forms have a $8 / v<0.1$, the MCC-1 leach data Implies nearly a 100x larger fractional release rate than actually expected.

Using a revised simulated SRP reference waste and the same FUETAP formula, the FURTAP m1x: MCC-6 series was leached to determine ine effects of the three standard MCC-1 leachants and two temperatures, $40^{\circ} \mathrm{C}$ and $90^{\circ} \mathrm{C}$ (Table 11.3). Comparing the data In Table 11.3, only the leaching of $\mathrm{Sr}$ and $\mathrm{U}$ In silica water shows a statistically significant difference between the MCC-1 leach rates (solubilities) at 40 and $90^{\circ} \mathrm{C}$. Since the revised SRP simulated waste used In this FUETAP mix: MCC-6 was more water demanding than the previous reference waste (Table 11.1 and 11.2), this formulation resulted in a specimen with $50 \%$ greater porosity ( 40\%). As a result, the Cs washouts were higher $(4-5 x)$ and the 28-day 
Table 11.1. Bffect of cenent type on the leach rates of various elenents fron FUETAP (KCC-1) concrete in delonized water

\begin{tabular}{|c|c|c|c|c|}
\hline \multirow[b]{3}{*}{ Cenent type } & \multirow{2}{*}{ 28-Day } & \multirow{2}{*}{\multicolumn{2}{|c|}{ HCC-1 leach rates at $90^{\circ} \mathrm{C}$}} & 81 \\
\hline & & & & $\overline{\mathbf{M}^{2}-\text { day }}$ \\
\hline & $\Delta \mathbf{1}$ & $\mathbf{P e}$ & Mn: & Sr \\
\hline Type I Portland & 3.31 & 0.0041 & 0.00096 & 0.43 \\
\hline Type I-S Slag & 1.57 & 0.0020 & 0.0234 & 0.39 \\
\hline $\begin{array}{l}\text { Pondu } \\
\text { (high alumina) }\end{array}$ & 5.67 & 0.0091 & 0.0152 & 0.83 \\
\hline $\begin{array}{l}507 \text { Type I + } \\
50 \% \text { Fondu }\end{array}$ & 4.11 & 0.0159 & 0.0268 & 0.11 \\
\hline
\end{tabular}

Table 11.2. Effect of Indian Red Pottery plus bentonite clay additives on the leach rates of cestum from PUETAP (HCC-1) concrete

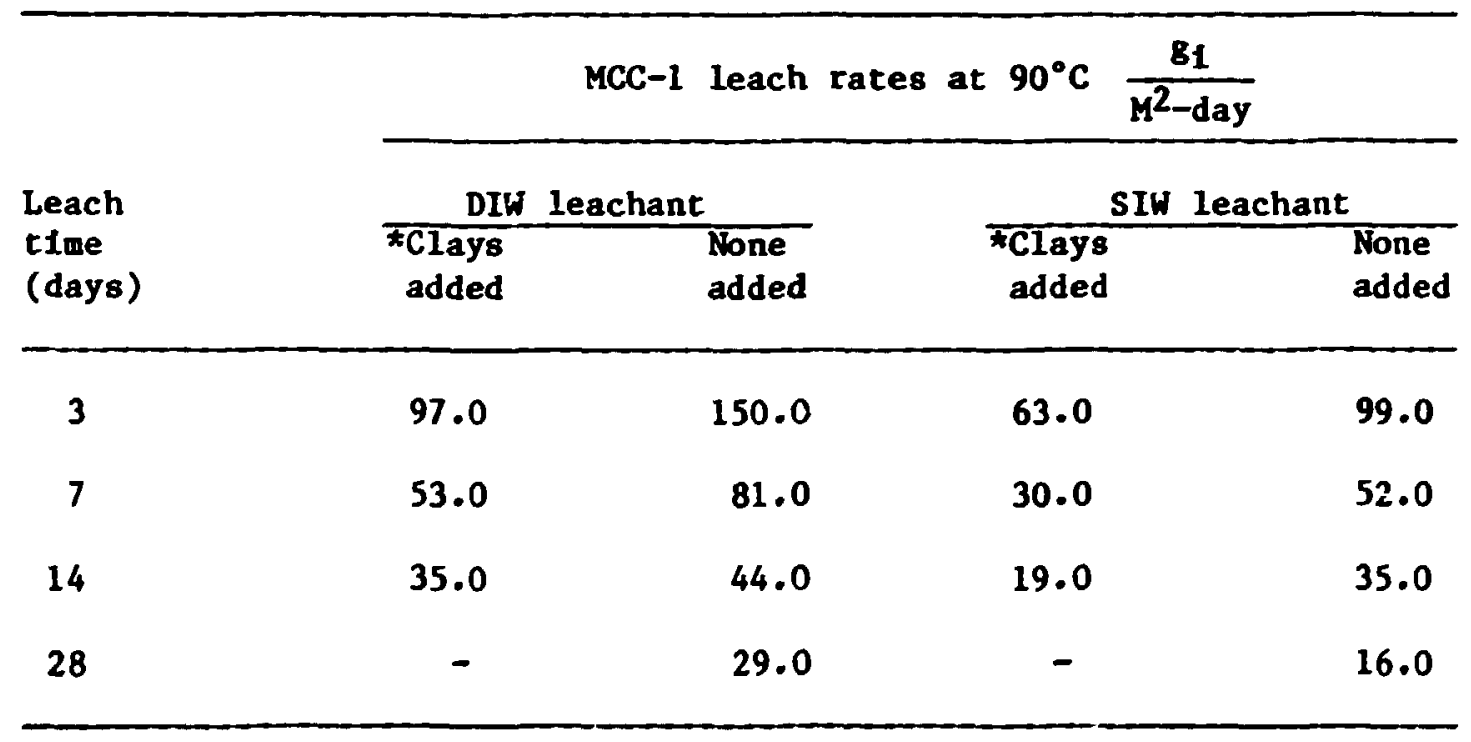

DIW - Quartz distilled water

SIW - MCC Bll1Ca water

$\star 3.5 \%$ Indian Red plus 3.5\% Bentonite added 
ORNL-DWG 81-15760

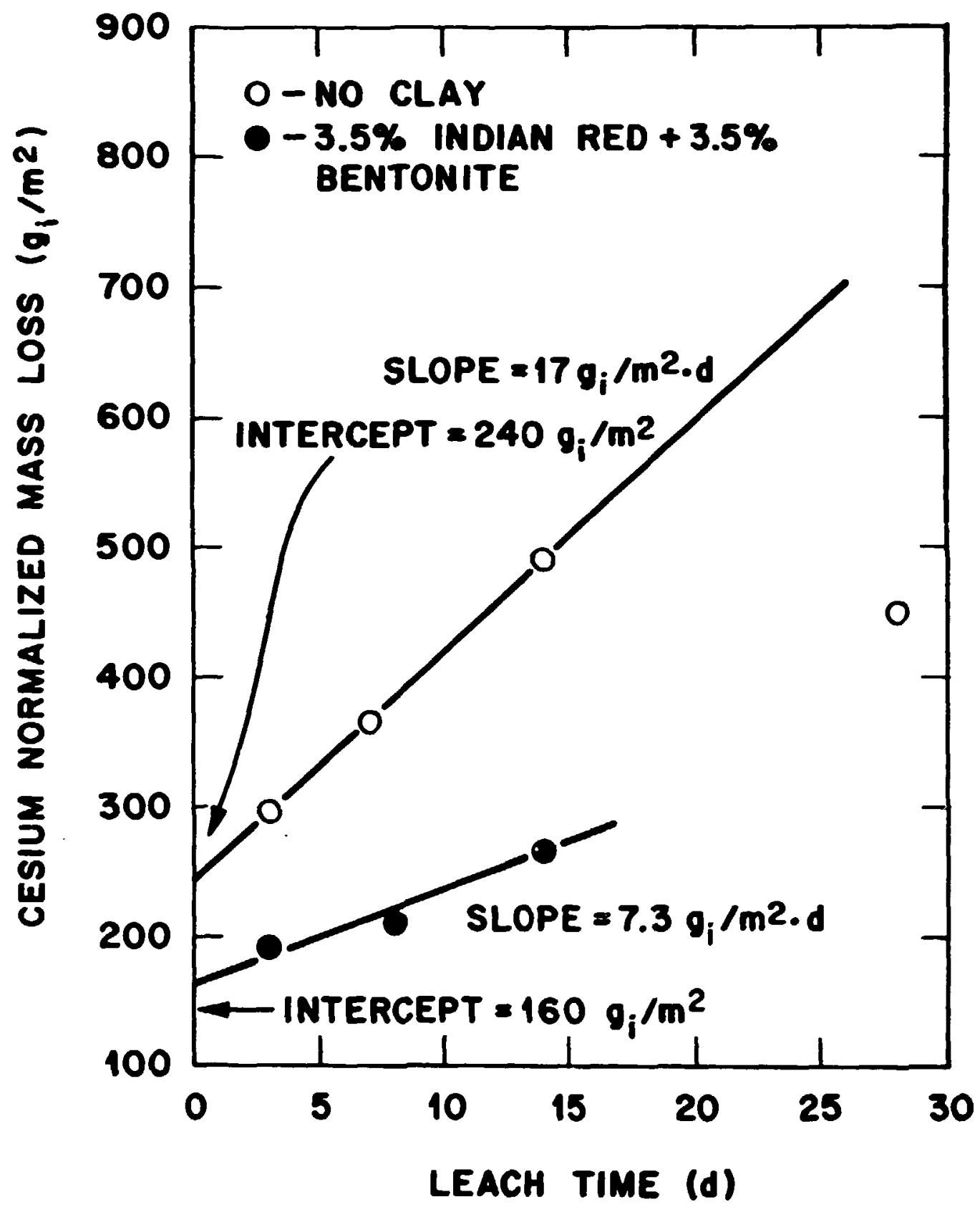

Fig. 11.3. Effects of clay additives on cesium leach rates from PUETAP (MCC-1) In silica water at $90^{\circ} \mathrm{C}$. 
ORNL DWG 81-598

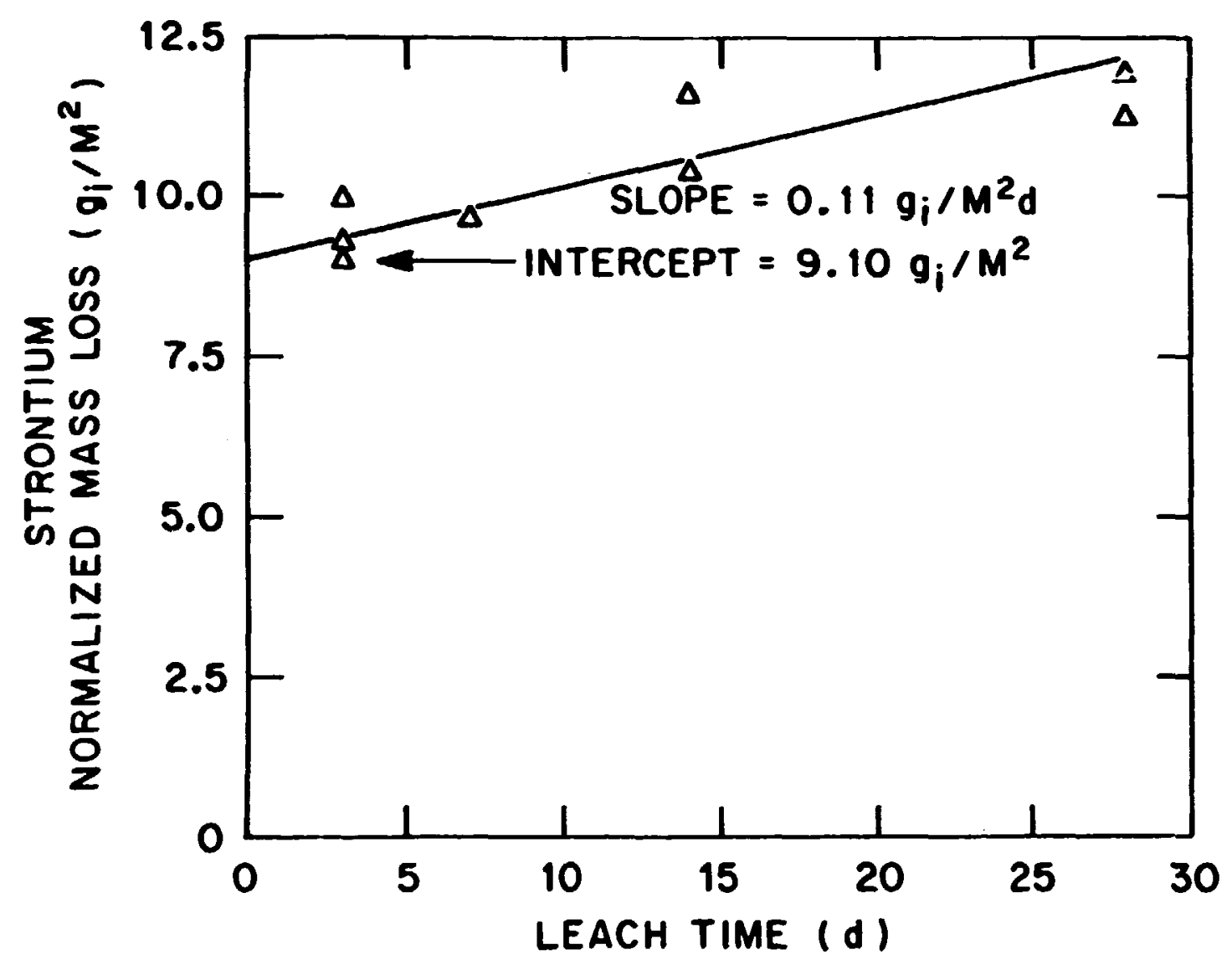

F1g. 11.4. FUETAP with Type 1 Portland Cement and SRP-4 - simulated waste MCC-1 strontium leach results at $90^{\circ} \mathrm{C}$ in delonized water. 
Table 11.3. Results of 40 and $90^{\circ} \mathrm{C} \mathrm{MCC-1} \mathrm{C8,} \mathrm{Sr,} \mathrm{U,} \mathrm{Ce} \mathrm{and} \mathrm{Nd} \mathrm{28-day}$

leash teats of FUETAP concrete mix: MCC-6 with Savannah River

Plant (SRP) simulated waste formula: SRP6A with Indian Red

Pottery clay (reduced-grams $/ \mathrm{M}^{2} \cdot \mathrm{d}$ )

\begin{tabular}{lcccccc}
\hline & $\begin{array}{c}\text { Temperature } \\
\left({ }^{\circ} \mathrm{C}\right)\end{array}$ & $\mathrm{Cs}$ & $\mathrm{Sr}$ & $\mathrm{U}$ & $\mathrm{Ce}$ & Nd \\
\hline $\begin{array}{l}\text { Distilled water } \\
\text { (DII) }\end{array}$ & 90 & $48 \pm 7$ & $.27 \pm .02$ & $.035 \pm .008$ & $.11 \pm .02$ & $<.1$ \\
$\begin{array}{l}\text { Silica waier } \\
\text { (SIW) }\end{array}$ & 40 & $46 \pm 3$ & $1.3 \pm .1$ & $.007 \pm .003$ & $.02 \pm .02$ & $<.1$ \\
& 90 & $37 \pm 3$ & $.30 \pm .01$ & $.02 \pm .01$ & $.02 \pm .01$ & $<.1$ \\
$\begin{array}{l}\text { Salt brine } \\
(\text { BRI) }\end{array}$ & 40 & $59 \pm 12$ & $17 \pm 6$ & $.06 \pm .01$ & $<.1$ & $1.0 \pm .5$ \\
& 90 & $53 \pm 5$ & $23 \pm 5$ & $.06 \pm .01$ & $<.1$ & $.6 \pm .2$ \\
\hline
\end{tabular}


leach rates are $0.8 x$ and $3 x$ higher than the DIW and SIW 28-day leack rates In Table 11.2, because of the washout blas in these data.

A statistical analysis of $70 \mathrm{MCC}-1$ leach results for uraniun (Tables 11.4-11.7) shows that there significant difference in uraniun concentrations (Pp) between sinulated raste fornulas SRP-6A and SRP-6B, which had 3.5\% Indian Red Pottery clay and sodiun bentonite, respectively (Table 11.4, whle Table 11.5 shows that there was no significant tine dependence of the uraniun concentrations (ppa). This indicates that the her:-1 test does not measure U-leaching, but rather U-solubility. Table 11.6 shows that it 18 the sane for $40^{\circ}$ and $90^{\circ} \mathrm{C}$ in WIPP Brine B (BRI). On the other hand, there was an Increase in U-solubility with temperature in the case of MCC-1 silica water (SIW).

No statistically significant difference in uranium solubility between dlonlzed water (DIW) and the sllica-water (SIW) leachants was observed (Tabj.e 11.7). However, the WIPP-brine B (BRI) could hold more uraniun In solution, probably due to the lower final pH of these brine leachates.

\subsubsection{Thermal Stability}

Thermal expansion measurements were made using samples whose inftial size was approximately $15 \mathrm{~mm}$ diameter by $31 \mathrm{~mm}$ long. These samples were made using the MCC-1 formulation whth SRP-4 waste solids cured and dewatered by the standard PUETAP method $\left(100^{\circ} \mathrm{C}\right.$ - cure, $250^{\circ} \mathrm{C}$ - dewater, 24 hour 8).

Samples were heated at a rate of $4^{\circ} \mathrm{C}$ per minute to $800^{\circ} \mathrm{C}$, held at $800^{\circ} \mathrm{C}$ for approximately five minutes, then returned to room temperature at a rate of $4^{\circ} \mathrm{C}$ per minute. 
Table 11.4. Duncan's multiple range test* for variable: uranium concentration vs. waste formula

(Means wth the same letter are not significantly different.)

Alpha $=0.05 \quad$ DF $=66 \quad$ MSE $=.0244771$

Harmonic mean of cell sizes $=34.5429$

\begin{tabular}{cccc}
\hline Duncan grouping & Mean & N & $\begin{array}{c}\text { Haste } \\
\text { foruula }\end{array}$ \\
\hline A & 0.16027 & 39 & SRP6B \\
B & 0.03877 & 31 & SRP6A \\
\hline
\end{tabular}

Table 11.5. Duncan's multiple range test* for varlable: uranium concentration vs. days leached

(Means wth the same letter are not significantly different.)

Alpha $=0.05 \quad$ DF $=66 \quad$ MSE $=.0244771$

Harmonic mean of cell sizes $=5.69637$

\begin{tabular}{cccc}
\hline Duncan grouping & Mean & N & Day \\
\hline A & 0.15214 & 10 & 3 \\
A & 0.10635 & 53 & 28 \\
A & 0.04583 & 3 & 7 \\
A & 0.03932 & 4 & 14 \\
\hline
\end{tabular}

*Note: This test controls error rates at different levels depending on the number of means between each pair being compared. Its operating characterlstics sonewhat resemble Fisher's unprotected LSD test. 
Table 11.6. Duncan's multiple range test* for variable: uraniue concentration (ppm) vs. tenperature

(Heans with the sane letter are not significantly different.)

On waste formila SRP6A leached in MCC-1 brine

$A l p h a=0.05 \quad$ DF $=5 \quad$ KSE $=2.0 \mathrm{E}-04$

Harmonic mean of cell sizes $=3.42857$

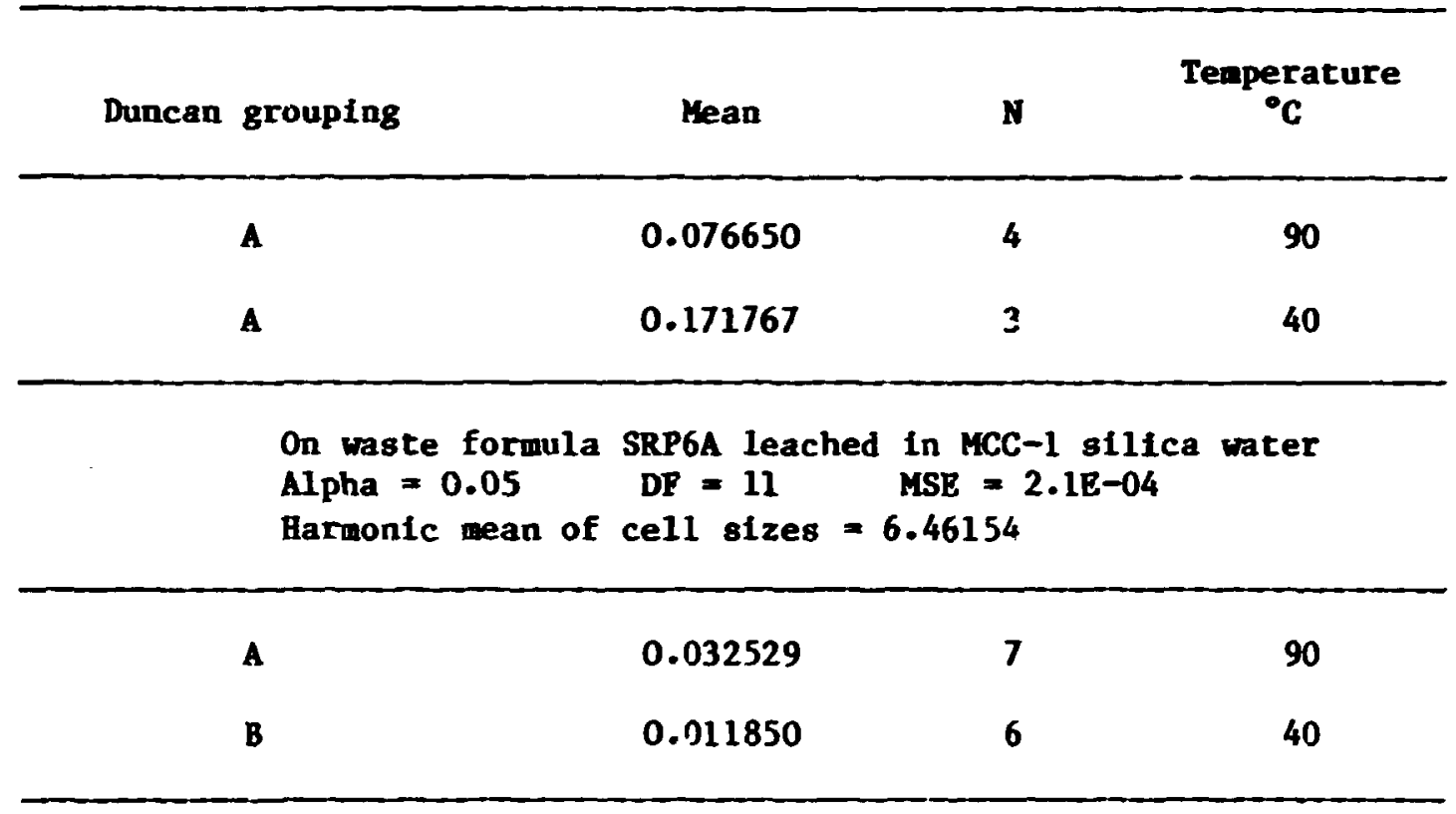

Table 11.7. Duncan's multiple range test* for vartable: uraniun concentration vs. leachant type

(Means with the same letter are not significantly different.)

$$
\begin{aligned}
& \text { Alpha }=0.05 \quad \text { DP }=66 \quad \text { MSE }=.0244771 \\
& \text { Harmonic mean of cell s1zes }=23.1555
\end{aligned}
$$

\begin{tabular}{cccc}
\hline Duncan grouping & Mean & N & $\begin{array}{c}\text { MCC-1 } \\
\text { leachant }\end{array}$ \\
\hline A & 0.24468 & 21 & Brine \\
B & 0.060207 & 23 & D-Water \\
B & 0.03576 & 26 & Silica water
\end{tabular}

*Note: Th1s test controls error rates at different levels depending on the number of means between each pair being compared. Its operating characteristics somewhat resemble plsher's unprotected LSD test. 
A typical expansion curve for the MCC-1 FUETAP formula is shown in Figure 11.5. During the heating cycle the sample length increased almost linearly to approxiastely 0.27 at $400^{\circ} \mathrm{C}$. The sample length continued to Increase in length up to approxinately $580^{\circ} \mathrm{C}$. This was caused by the transition from low to high quartz. The sample length remained fairly constant between $600^{\circ} \mathrm{C}$ and $700^{\circ} \mathrm{C}$. At approxinately $700^{\circ} \mathrm{C}$ the sample began shrinking rapidly. At $800^{\circ} \mathrm{C}$ the sample expansion was approximately $-0.7 \%$.

Upon cooling, the sample shrank IInearly until a sharp drop occurred at approximately $580^{\circ} \mathrm{C}$, caused by the reversible transition from high to low quartz. At room temperature again, the final thermal expansion was approximately -1.77 of the original length.

Using the expansion curve In Figure 11.5, an average thermal expansion coefficient of $4.7 \times 10^{-6} /{ }^{\circ} \mathrm{C}$ can be derived between $20^{\circ} \mathrm{C}$ and $400^{\circ} \mathrm{C}$. This coefficient is about half that of most HLW glasses and hard rolled steel.

\subsubsection{Sumary and Conclusions}

Where do FUETAP concretes stand wth regard to the major questions concerning the performance of radloactive waste forms?

With regard to leachablitty, the dynamic leach rates of transuranics are below our detectable limfts $\left(<0.01 \mathrm{~g}_{1} / \mathrm{M}^{2} \mathrm{~d}\right)$. Cs and $\mathrm{Sr}$ leachabilities compare with glass, but the Inittal washout is higher. These leach rates are sufficiently low to meet the Intent of the proposed NRC 10 CPR 60, without credit for the package.

Radiolytic decomposition of these low-water (<2\%) PUETAP concretes is negligible over $7 \times 10^{5}$ years. They are thermally stable to $900^{\circ} \mathrm{C}$ and have thermal expansions less than steel. 
ORNL DWG 81-547R

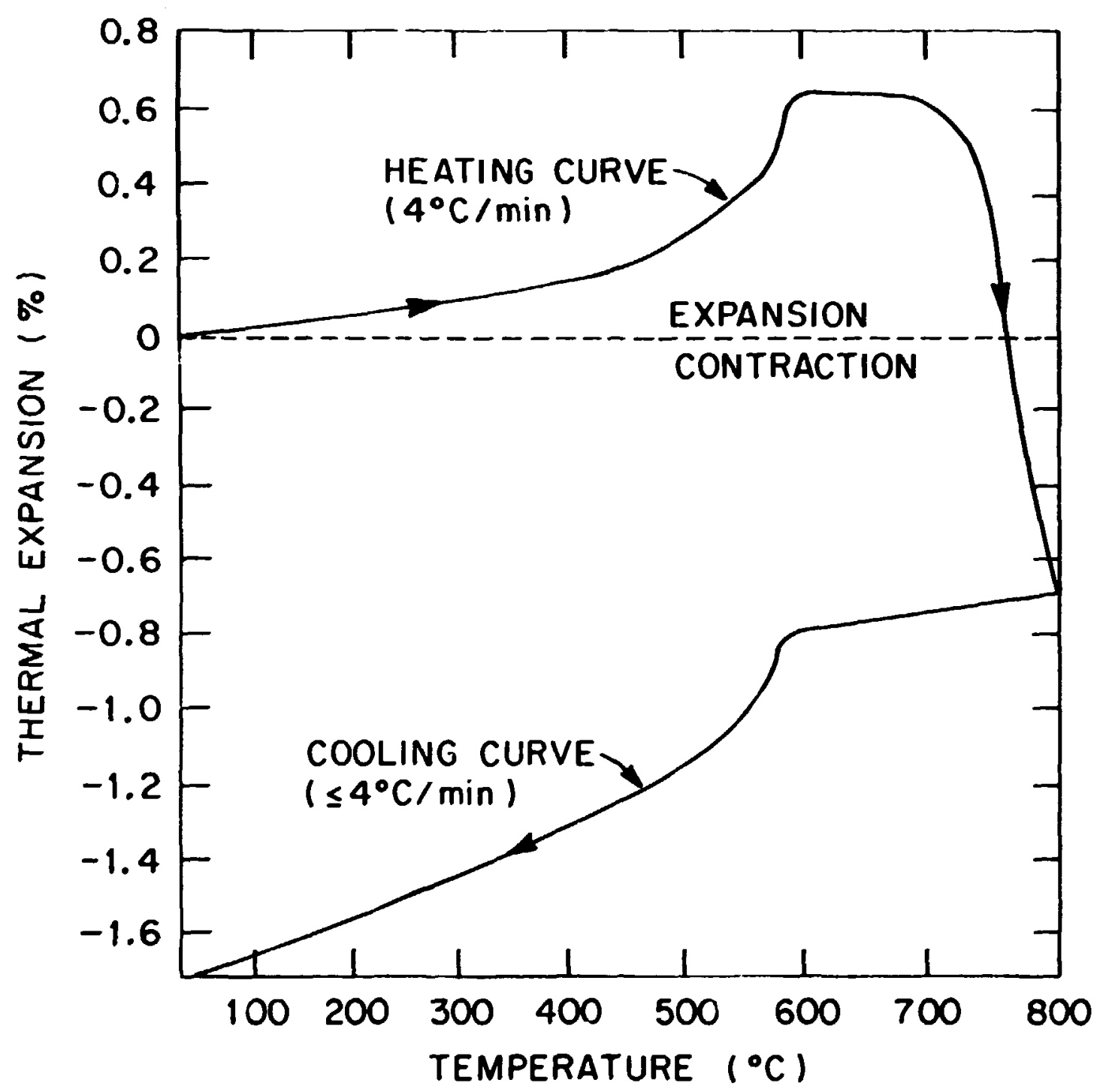

Pig. 11.5. Typlcal expansion curve of an MCC-1 type concrete. 
FUETAP concretes are high strength concretes (40-100 MPa, compressive strength) and produce less than 0.4 wt $Z$ respirable fines upon impact of $\sim 10 \mathrm{~J} / \mathrm{M}^{3}$. Their porosities, permeabilities $\left(\sim 10^{-5} \mathrm{darcy}\right)$, thermal conductivities, and densities are inversely proportional to their water:cement $(w / c)$ ratlos. In turn, the $w / c$ depends on the process rheological limits and the water demand of the specific waste stream. The formula must be tallored to obtain compatibility with specific waste stream, processing/implacement technology, and disposal environment.

Since concrete is already the principle radwaste host for most lowand Intermediate-level waste, and accelerated curing is a common Industry practice, no Inventions are required to apply the FUETAP process. It uses inexpensive and readily avallable materials, which process at low temperatures. This process works with a broad range of waste streams and cementitious materials.

The cementitious and radioactive waste phases are complex mixtures, and the identification and location of their specific nuclides has just begun. However, FUETAP concretes have already been shown to work as durable, tenaclous hosts for most of the major defense and reprocessing radioactive waste streams.

\subsubsection{High-Level Waste Contalner Development}

The wurk accomplished under this program in PY 1982 included the corpletion of the post exposure examination of test specimens, and preparation of a final report. The abstract of the final report is given below: 
H. E. HeCoy, Studies of Waste-Canister Compatibllity, ORNL/TM-8491 (In publication).

Compatiblilty studies were conducted between 7 waste forms and 15 potential canister etructural materials. The waste forms were Al-Si and with carbon or carbor plus sllicon carbide. The canister naterials included carbon steel (bare and with chromium or nickel coatings), copper, Mc:el, Cu-357 M1, titanium (grades 2 and 12), several Incisncels, aluminum alloy 5052, and two stainless steels. Tests of elther 0888 or $8821 \mathrm{~h}$ were conducted at 100 and $300^{\circ} \mathrm{C}$, wich bracket the low and high ilmits expected during storage. Glans and FUErAP evolved sulfur, which reacted preferentlally with copper, nickel, and alloys of these metals. The $\mathrm{Pb}-\mathrm{Sn}$ matrix alloy stuck to all samples at $300^{\circ} \mathrm{C}$, but the extent of chemical reaction was not determinef. The carbon-coated praticles also stuck to most samples at $300^{\circ} \mathrm{C}$, but the extent of chemical reaction was not determined. Testing for 0.5 in at $800^{\circ} \mathrm{C}$ was included because it 18 representative of a transportation accident and is required of casks containing nuclear materials. During these tests (1) glass and FUETAP evolved sulfur, (2) FUEThip evolved large anounts of gas, (3) Synroc stuck to titanlum alloys (4) glass was molten, and (5) both matrix alloys were molten with consideratle chemical interactions with many of the canister samples. If th1s test condition were lmposed on waste canisters, it would be design limiting in many waste storage concepts.

\subsubsection{ORNL So1-Ge1 Coated Particle Haste Form Development}

Progress during FY 1982 included completion of several development tasks Inftiated during FY 1981, and final documentation of the program.

The documentation was completed in four reports. Acstracts of the reports are Included below:

W. D. Arnold et al, "Preparation of Gel Spheres Contalning Simulated High-Level Radioactive Waste," Radioactive Waste Management and Lhe Nuclear Fuel Cycle, Volume 3 (1), September 1982 (pp. 57074).

Gel-derlved microspheres contalning slmulated high-level radloactive waste sludge and ceramic additive mater' ' '... :e prepared by internal gel.ation at waste loadings as $\mathrm{high}$ as $90 \%$. ate gel spheres were amenable to subsequent drying, olntering, and coating procedures producing highly leach-resistant crystalline waste forus sultable for permanent disposal. Potential application of this technique to commerclal power reactor waste prncessing was demonstrated by Incorporating slmulated Purex solvent extraction waste In gel spheres at $20 \%$ waste loading. 
W. D. Arnold et al, Incorporation of Simulated High-Level Nuclear Waste in Gel Sphere, ORNL-TM/8124, Decenber 1982 .

Gel sphere technology developed for reactor fuel fabrication was applied to the fixation of simulated high-level radioactive waste in crystalline ceramic fore for permanent disposal. Gel spheres containing simulated alkaline defense waste sludges and cerantc matrix materials were prepared by internal gelation at waste loadings as high as $90 x$. The gel spheres were anenable to subsequent drying, sintering, and coating procedures to produce crystalline wate forms with extremely high leach resistances. Potential application of this technique to the processing of commercial power reactor waste was demonstrated by incorporating simualted Purex solvent extraction waste in gel spheres with up to z0X raste ioading. Cestum present in the sinualted waste was adsorbed on zeolite and imobilized by coating with carbon.

D. P. Stinton et al, "Coating of Crystalline Nuclear Waste Forms to Improve Inertness," Journal of the American Ceramic Society, Vol - 65, No. 8.

Microspheres of a crystalline waste form prepared by sol-gel processing were successfully coated with layers of pyrolytin carbon and silicon carbide to isolate the radioactive wastes from the biosphere. A separate process for cestum Immoblilization was developed, which loads 5 wt $\%$ Cs onto zeolite particles for subsequent coating. Pyrolytic carboncoated particles showed leach rates $\sim 2$ to 4 orders of magnitude less than the candidate reference borosilicate glass waste form. Aqueous leach-test results of coated waste forme were below detection limits of such sensitive analytical techniques as atomic absorption and Inductively coupled plasma atomic emission.

D. P. Stinton et al, "Immobilization of Radioactive Cesidm In Pyrolytic Carbon-Coated Zeolite," submitted to the Journal of the American Ceramic Soc1ety in September 1982.

All waste forms currently being developed for radwaste disposal have difficulty lmmobilizing cesium. A new waste form was developed to dispose of ceslum by loading up to 5 wt $\% \mathrm{Cs}$ onto zeolite granules. These zeolite particles are then heat-treated and coated with pyrolytic carbon and/or Sic to completely immobilize cesium. The leach rate of cesium from pyrocarbon-coated zeolite is 3 to 4 orders of magnitude less than for other waste forms. We therefore propose that cesium be romoved from the primary waste stream and loaded onto zeollte granules for subsequent coating. The total waste form (prinary waste form plus coated zeolite) would have acceptable leach: resistance for all radwaste components and extremely leach resistant for ceslum. 
11.4 REFERENCES

1. N. E. BIbler In: Proceedings of the Conference on the Scientific Basis for Nuclear Waste Management, Vol. 2, C. J. M. Northrup ed. (Plenum Press, New York 1980), pp. 525-582.

2. S. Katz In: Proceedings of the Conference on the Scientific Basis for Nuclear Waste Management, Vol. 2, J. G. Moore ed. (Plenum Press, New York 1980), Pp. 577-58:. 


\section{INTEgRATEd DATA BASE PROGRAM}

R. J. Notz

\subsection{INTRODUCTION}

This program was Initiated in FY 1980 for the purpose of establishing and maintaiuing a computerized, integrated data base of current and projected nuclear wastes in the United States. A consistent set of evaluated Information on waste Inventories, characteristics, sources, package descriptions, and locations of interin storage and disposal sites is needed by the DOE and other agencies and contractors for use in waste program planning and systens analys1s. The data base will also include costs, and will be capable of taking into account the effects of different methods of chendcal treatment and packaging on the characteristics of final waste forms.

This program is jointly funded by Commerclal Waste Management and Defense Waste Management, and is carried out in a fully integrated manner. Thus, this work is shown under both funding sources (see also Section 6) but is reported in detail only once, in this section.

\subsection{PROGRESS}

Technical progres.; for the task of this program for the fiscal year just ended follows.

\subsubsection{Integrated Data Base Program (C. W. Alexander, W. L. Carter,} C. W. Forsberg, H. W. Godbee, B. M. Horwedel, A. H. Kibbey, and G. W. Morrison)

The mafor thrust of the program is to develop and build a reliable, easily accessible, and versatile data base that covers all domestic spent fugl and radwaste and that uses computerlzed data handing capabilities effectively. 
Bssential components of the data handling capability are (1) conputerized data input, (2) electronic transfer of data, and (3) a data base managenent systen that provides direct, easy, and fast access to data in the systen. This access nust also allow tallered data output to serve specific needs in terms of content, forest, and presentation, both tabular and graphical. In support of these objectives, the IDB Progran has major tasks in four ureas:

- To develop the data handling capability, using state-of-the-art hardware and software, and focusing on the urgent need to facilitate fast, accurate, and easy access by users;

- To develop a data base of Inventorles, sharacteristics, source terns, packaging, and costs covering all domestic spent fuel and radwastes (Including HLW, TRU waste, LLW, alrborne waste, mill tallings, renedial action wastes, and D\&D wastes; frow the comnercial fuel cycle, from Institutional and Industrial (I/I) activities, and from DOE/defense functions;

- To develop the necessary models to allow projections of future quantitles and characteristics of spent fuel and radwaste, Including the capability to deal easily and quickly with alternative projection scenar10s and treatment/handling varlations;

- To maintal. and enhance the ORIGEN2 model and code systere for calculating detalled isotopic generation and depletion, for application to spent fuel and all categories of radwaste. In addition to these four tasks, the program provides direct support for special needs for directly derived information and also carries out related studies, under separate funding, that draw heavily on IDB 
background Inforation and/or capabilities, but go beyond the scope of the IDB Program itself. Two of these separately funded studies are also described in Chapter 15: IRU Comercial puel Cycle Studies and TRO Isotope Decay Chains.

A major project each year that draws heavily on all four of the task areas outlined above 18 the preparation of an annual report covering all dowestic spent fuel and radwaste inventories, projections, and characteristics; the third such report was 1ssued recently. 1 This project uses the capabilities and data developed by these task areas, anci brings existing capabilities to a focus. It also serves as an ideal vehicle to present, under a single cover, a huge amount of related data. No other publication in the fleld has this scope of coverage. The report also helps to Identify weak areas, where more or better data are needed, where Improved or modified data handling capabilities are required, and It permits (and encourages) a critical review of the data by all Interested users, to everyone's benefit. An overall sumary table, taken frow the latest report, 18 given in Table 12.1. Many of the characteristics were calculated and projected using newly developed ORGENTRE (Oak RIdge Generation and Treatment) codes. The waste Inventory data are acquired through the cooperation of the lead offices that were established by the DOE to oversee the management of the various types of waste. It 18 expected that future reports containing additlonal Information will be published perlodically as the ORGENTRE system becomes fully developed and operational. A special session on Radwaste Inventories and Profections ${ }^{2}$ was held at the ANS National Meet Ing in Los Angeles, June 1982, Including three papers describing this work.3-5 
Table 12.1. Spent fuel and radraste Inventories as of Decenber 31,1981

\begin{tabular}{|c|c|c|c|}
\hline Spent fuel & Mass, Mro & Activitz: kCI & Heat, $\mathbf{u}$ \\
\hline $\begin{array}{l}\text { BRs (18,700 assenblies) } \\
\text { PWRs (10,900 assenblles) }\end{array}$ & $\begin{array}{l}3,300 \\
4,500\end{array}$ & $\begin{array}{l}3,360,000 \\
6,960,000\end{array}$ & $\begin{array}{l}12,500 \\
26,700\end{array}$ \\
\hline High-level mate & Volune, $7^{3}$ & Activity, $k C_{1}$ & Heat, ld \\
\hline $\begin{array}{l}\text { Savannah River } \\
\text { Idaho CPP } \\
\text { Banford } \\
\text { Euclear Ruel Servicea }\end{array}$ & $\begin{array}{r}106,000 \\
12,000 \\
183,000 \\
2,190\end{array}$ & $\begin{array}{r}982,000 \\
64,000 \\
531,000 \\
39,000\end{array}$ & $\begin{array}{r}2,900 \\
210 \\
1,640 \\
115\end{array}$ \\
\hline Transuranic wate & Folune, $\mathbf{n}^{3}$ & Activity, $\mathrm{kCl}_{1}$ & IRU elements, $\mathrm{kg}$ \\
\hline $\begin{array}{l}\text { DOR, burled } \\
\text { DOE, atored } \\
\text { Cor,erclal, burled }\end{array}$ & $\begin{array}{c}299,000 \\
67,000 \\
(1 n \text { with LWH) }\end{array}$ & $\begin{array}{r}400 \\
1,000 \\
-\end{array}$ & $\begin{array}{r}1,000 \\
910 \\
130\end{array}$ \\
\hline Low-leve 1 rasts & Volune, $\mathbf{n}^{3}$ & Activity, $\mathrm{kCI}$ & Land used, ha \\
\hline $\begin{array}{l}\text { DoE sites } \\
\text { West Valley (closed 1975) } \\
\text { Maxey Flats (closed 1977) } \\
\text { Sheffleld (closed 1978) } \\
\text { Barnuell, sC } \\
\text { Beatty, iN } \\
\text { Richland, WA }\end{array}$ & $\begin{array}{r}1,607,000 \\
66,500 \\
135,000 \\
88,000 \\
363,000 \\
93,000 \\
102,000\end{array}$ & $\begin{array}{r}10,700 \\
580 \\
2,400 \\
60 \\
3,000 \\
370 \\
1,020\end{array}$ & $\begin{array}{r}159 \\
3 \\
6 \\
4 \\
19 \\
11 \\
11\end{array}$ \\
\hline Remedial Action Progran & Volume, $m^{3}$ & Act1vity, $k C_{1}$ & No. of g:ces \\
\hline $\begin{array}{l}\text { DMIRAP } \\
\text { PUSRAP } \\
\text { SEP }\end{array}$ & $\begin{array}{r}22,000,000 \\
452,000 \\
1,560,000\end{array}$ & $\begin{array}{ll} & 150 \\
--- & \end{array}$ & $\begin{array}{r}24 \\
31 \\
\sim 500\end{array}$ \\
\hline Active mill tallings & Volume, $\mathrm{m}^{3}$ & Activity, kCI & Heat, $\mathrm{kH}$ \\
\hline 21 active mils & $87,000,000$ & $\therefore, 000$ & 20 \\
\hline
\end{tabular}


The IDB Progran obvlously nust draw upon data sources outside of its own funding area, and work closely with wany other prograns and with contractor lead sites and DOE Field Offices and HQ staff in order to achieve effective integration. To facilitate this, a steering condtee has been set up, with memership representing all major prograns and functional areas directly related to spent fuel and radwastes. The connittee 18 backed up by technical contacts and DOE contacts. As progrannatic changes occur, the comittee nemership also changes to reflect th1s. The makeup of the comittee as of June 1982 is given In Ref. 1. A serles of computer codes and data files called ORGENTRE is being developed to handle this information and to project nuclear waste generation and treatment options. It consists of the following major components :

1. A serles of waste generation codes and data bases comprising (a) characteristics of the existing inventory, (b) a nuclear materials projection code to calculate the fissile and fertile materials throughputs of all fuel cycle facilities for any given nuclear power bulldup and reactor mix, (c) a defense waste profection code, and (d) an Institutional/Industrial waste projection code.

2. A waste treatment simulation code to calculate the characteristics of secondary wastes that are generated as a consequence of any proposed treatment process.

3. A system data base composed of several 11 braries contalning fuel cycle facility and waste treatment process flowsheet data, and tables of pertinent nuclear and engineering conversion constants. 
4. An econoucs data file and code to detemine the cost of varlous treatnent options.

5. An output file containing the Identity and characteristics of all the wastes that have been finally generated and projected, and a data base manager progran that 18 needed to supply tabular and graphical representations of these data.

The overall data flow and information handling scheme is shown in F1g. 12.1. Isotope generation and depletion are handled by the ORIGEN2 code system and data files are managed with SAS (Statistical Analysis System). SAS has been an extremely helpful tool. It can take as input virtually any pre-existing computer data file, generates our own tabular output (which we then print directly on a CF:-8000 word processor through a link to a PDP-10 large computer), can produce graphics (see Ref. 1 for examples of pie charts and line graphs), and will mesh with any future DBMS (Data Base Management System) the program may elect to use.

The ORIGEN2 code for 1sotope generation and depletion calculations predates this program6-8 but is now supported by the IDB Program because 1t is an essential element in ORGENTRE. ORIGEN2 is the most widely used code for the calculation of lsotopic composition of spent reactor fuel. We also use it to compute decay of the various radioactive wastes. It can also apportion the total spent fuel assemblage into various components, such as fuel, cladding, and structural materlal or, for the reprocessing case, Into recovered $U$ and $\mathrm{PU}, \mathrm{HLW}, \mathrm{TRU}$ waste, effiuents, and structural material. The ORIGEN2 code has been modeled for many 
ORNL DWG 82-945

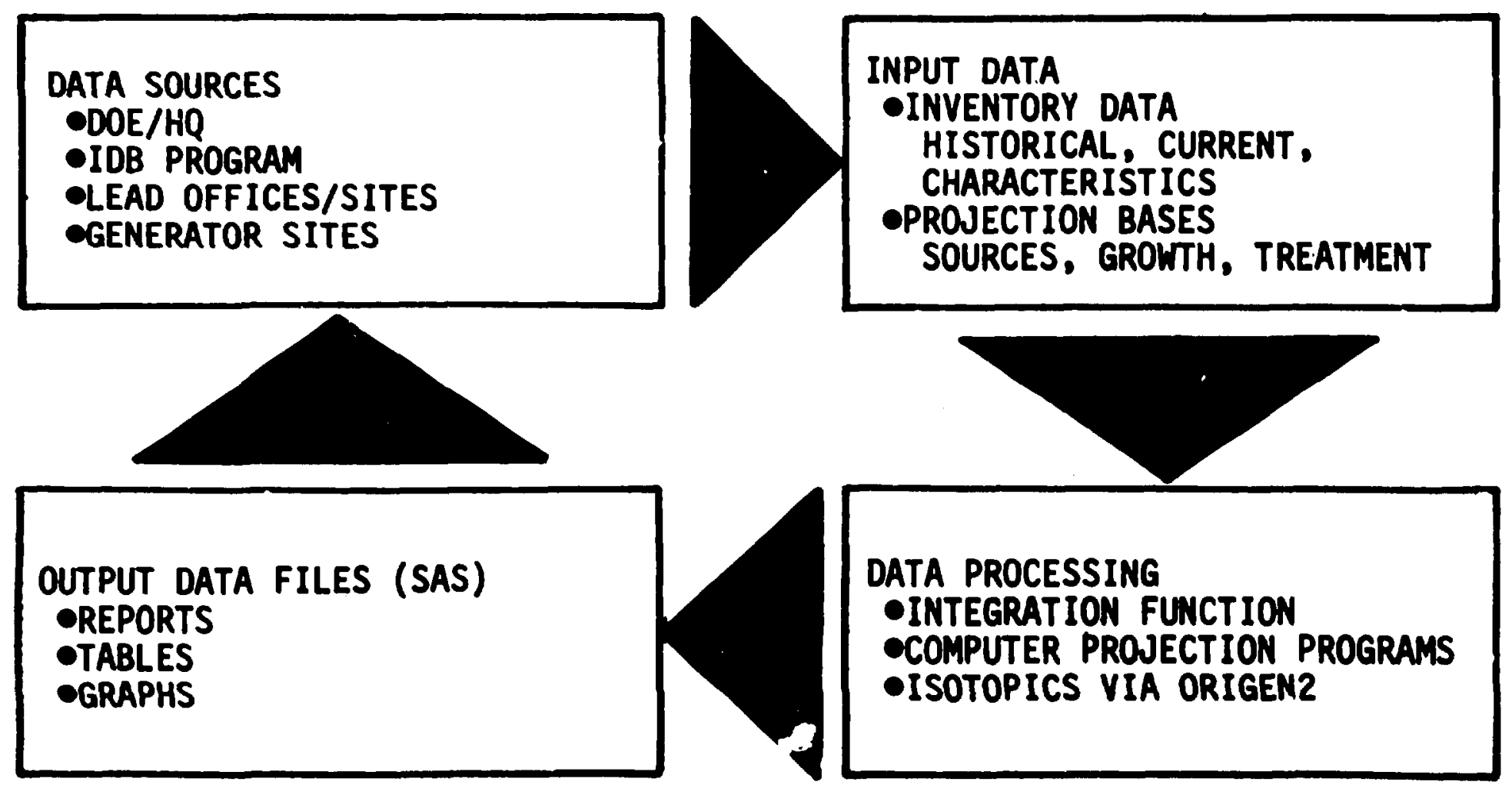

Fig. 12.1. Data Flow for Integrated Data Base Program 
reactor systens and variations thereof, including many LWR and LMPBR cases. Four reports have been issued recently dealing with specific cases. 9-12

A bibliographic file is also being created, wh emphasis on inventories, projections, and characteristics. Abstracts, key words, and other pertinent information are stored in a computer file that is designed to facilitate machine searches. A two-volume bibllography 1,14 (abstracts and indices) has been published and alsc an update.15 The program was also responsible this past year for pubilcation of the Radioactive Waste Management Newsletter.16

\subsection{PUBLICATIONS AND SEFERENCES}

1. Spent Puel and Waste Inventories, Projf:ctions, and Characteristics, DOE/NE-0017-1 (October 1982).

2. K. J. Notz, Radwaste Inventories and Projections: An Overview, ORNL/TM-8322 (July 1982).

3. E. F. Mastal, "Data Base Needs and Functions; National Planning," ANS Nat lonal Meeting, Los Angeles, CA, June 1982; Proceedings, Vol. 42, pp. 80-81.

4. K. J. Notz, W. L. Carter, and A. H. Kibbey, "Integrated Data Base for Spent Fuel and Radwaste: Inventories," ANS National Meeting, Los Angele8, CA, June 1982, Proceedings, Vo1. 42, pp. $8 \mathrm{i}-83$.

5. C. W. Forsberg, C. W. Alexander, and G. W. Morrison, "Integrated Data Base Projections," ANS National Meeting, Los Angeles, CA, June 1982; Proceedings, Vol. 42, pp. 83-84.

6. M. J. Bell, ORIGEN - The ORNL Isotope Generation and Depletion Code, ORNL-4628 (May 1973). 
7. A. G. Croff, A User's Manual for the ORIGEY2 Computer Code, ORNL/TM-7175 (July 1980).

8. A. G. Croff, ORIGEN2 - A Revised and Updated Version of the Oak RIdge Isotope Generation and Depletion Code, ORNL-5621 (July 1980).

9. A. G. Croff and C. W. Alexander, Decay Characteristics of Once-Through LWR and LMFBR Spent Fuels, High-Level Wastes, and Fuel Assembly Structural Material Wastes, ORNL/TM-7431 (November 1980).

10. A. G. Croff and M. A. Bjerke, Alternative Fuel Cycle PWR Models for the ORIGEN Computer Code, ORNL/TM-7005 (February 1980).

11. A. G. Croff, J. W. McAdoo, and M. A. Bjerke, LMFBR Models for the ORIGEN2 Computer Code, ORNL/TM-7176 (October 1981).

12. A. G. Croff, M. S. Liberman, and G. W. Morrison, Graphical and Tabular Sumnaries of Decay Characteristics for Once-Through PWR, LMFBR, and FFTF Fuel Cycle Materfals, ORNL/TM-8061 (January 1982).

13. C. A. Johnson and P. A. Garland, Radioactive Waste Management Integrated Data Base: A B1bliography, ORNL/TM-7385/V1 (Indices) (September 1980).

14. C. A. Johnson and P. A. Garland, Radioactive Waste Management Integrated Data Base: A E1bllography, ORN/TM-7385/V2 (C1tations) (September 1980).

15. C. A. Johnson, Radloactive Waste Management: A Bibliography for the Integrated Data Base Program, 0RNL/TM-7385/V3 (Update) (October 1981).

16. "Radioactlve Waste Technology Program Newsletter," Isque No. 15 (November 1981); Issue No. 16/17 (May 1982); Issue No. 18 (August 1982). 
12.4 REFERENCES

None. 


\title{
13. LOW-LEVEL WASTE MANAGEMENT PROGR:M
}

\author{
L. J. Nezga, N, H. Cutshall
}

\subsection{INTRODUCTION}

In FY 1982 two tasks, (1) the Low-Level Waste Information Center and (2) the Tn State Screening project were performed as Low-Level Waste Commercial Nuclear Waste Programs. These tasks were carried out under the overall management of the Program Manager at DOE's Idaho Operations Office, the lead contractor, (EG\&G, Idaho) at the Idaho National Engineering Laboratory, and DOE's Oak Ridge Operations office.

\subsection{PROGRESS}

Technical progress for each of the tasks 0 : this program for FY 1982 follows:

\subsubsection{Low-Level Waste Information Center (C. S. Fore)}

The Low-Level Waste Information Center continued in its function to support the U.S. DOE's National Low-Level Waste Maragement Program. (LLWMP). As of January 31,1982 , LLWMP funding for this effort was ceased, and all future tasks were supported through U.S. DOE's Integrated Data Base Program.

The task provided information support to the Low-Level Waste Management Program. This was achieved by maintenance of a bibliographic data base containing scientific literature pertinent to the Low-Level Waste Management Program. The data hase makes this information readily available to researchers and decision makers involved with low-level radioactive wastes. Hork is divided intn three activities: (1) information collection and analysis, (2) purblications, and (3) request handling. 
The accomplishments for the funded period October 1, 1981 to February 1, 1982 were as foliows: (1) identified, collected, analyzed, abstracted, indexed, and disseminated technical information relevant to low-level radioactive waste technology - approximately 200 new documents were received and 150 abstracts were written and entered into the online data base; (2) compiled and published one newsletter on radioactive waste technology receiving a distribution of approximately 1000; and (3) responded to 300 information requests for governmental, academic, industrial, and foreign affiliations.

13.2.2 State Screening Project (J. T,. Cannon, W. P. Staub, P. R. Ir.tenann, and L. E. Stratton)

This project supports the DOE Low-Level Waste Management Program responsibility for providing b:ssic techni: $a l$ assistance to requesting states and regional groups considering sites $f^{\prime}$ dispcsal of low-level radioactive waste. This support to states is the responsibility of EG\&G-Idaho. The ORNL team works with EG\&G staff in this project. Th.e technical assistance includes: (1) the development of screening parameters and a screening process, based on $10 \mathrm{CFR} 61$ and work in the low-level waste management program, applicable to the existing geographic, hydrologic and geologic s jotems of the particular state and/or region; and (2) application of the screening process through a reconnaissance-level investigation to identify potentially suitable areas and sites for low-level waste disposal. The current focus of the project is the State of Tennessee which is used a a model to demonstrate a procedure for locating low-level waste disposal site!s. The results of the project are intended to be of direct use to the State of Tennessee, and will be available to other states as generil information and support for site selection projects. 
A formal site selection process for a low-level waste disposal facility may be formulated as three levels of consideration: (1) the region is screened for suitable areas; (2) the areas are screened for potential viable sites on more detailed scale; and (3) the potential viable sites are screened to yield recommended sites. As shown in Fig. 13.1, each sceg progresses to a smaller geographic unit and involves more detailed information. Table 13.1 lists the criterion measures which are to be used at each screening level of this process. The criterion measures were developed from ennsideration of the Nuclear Regulatory Commission's proposed waste-disposal regulation $10 \mathrm{CFR} 61$.

The first level of screening in this site selection process was conducted for the state of Tennessee to ascertain the subregions within the state most likely to have suitable areas. The subr gions were defined as physiographic provinces wich are finite divisions of land with distinct geologic and geomorphic characteristics (Pig. 13.1). Based on the screening criteria and screening factors (Table 13.1), only the eastern Mississippi Embayment was found to have all of the desirable natural features to meet the criteria for shallow land burial of low-level waste. The remaining physiographic provinces were excluded on the basis of one or a combination of the following: (1) geolozical hazards, (2) complex features such as karst topography and faults that may not be readily amenable to reliable hydrogeologic analysis, and (3) insufficient overburden. Pigure 13.2 shows the composite suitability map. 
ORNL-OWO 62-15306

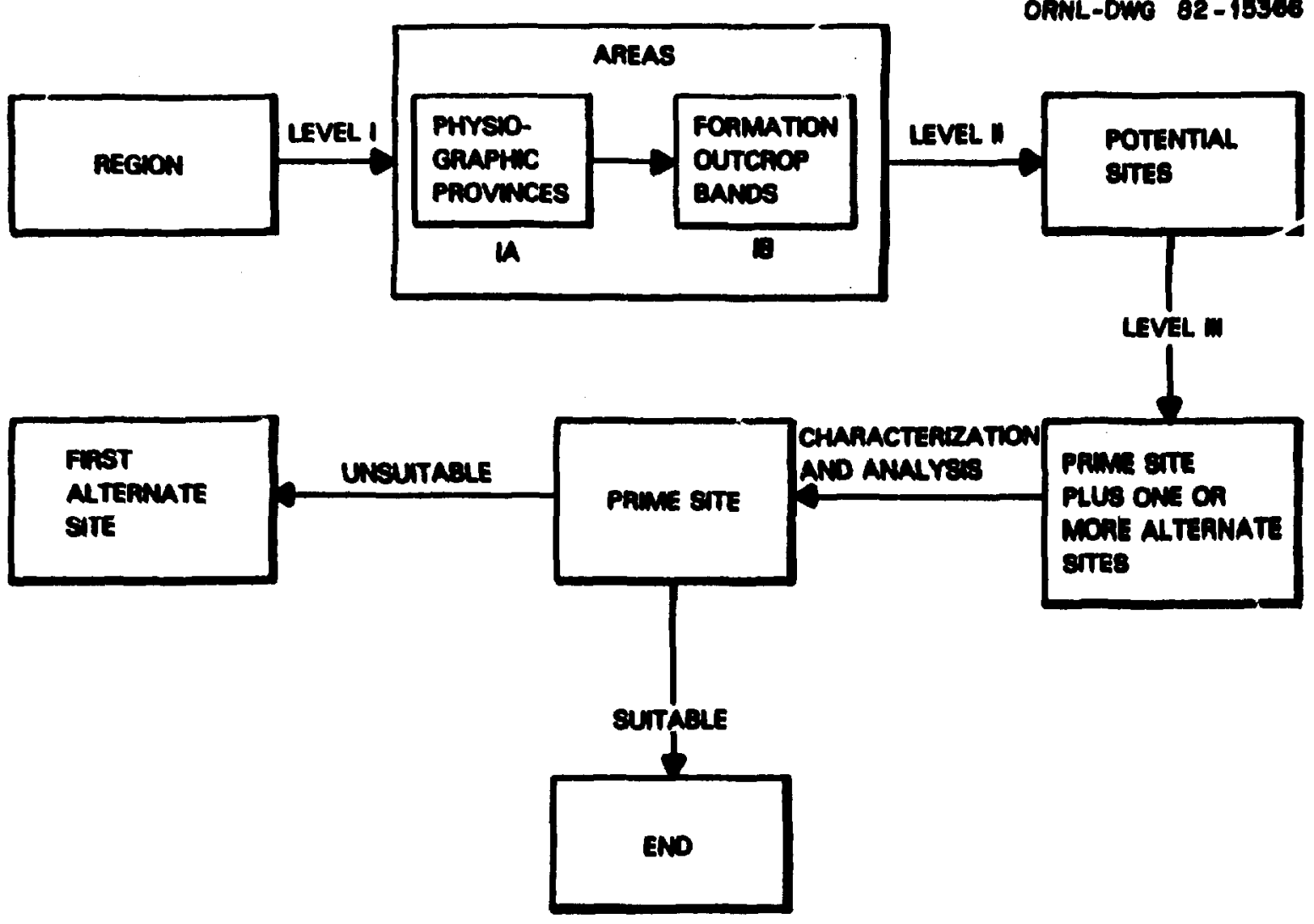

Figure 13.1. Screening levels and analysis. 
Table 13.1 Criteria mesurements: iaforention resdily arailable for initial screenio and informtion required for sice licensing

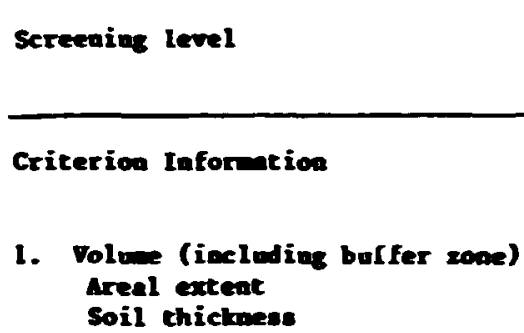

2. Depth to water table

3. Flood haxard Drainace divides loo-st flood plein

4. Erovion potentiel

5. Cechydrologic predictability Solution cavitie: Geweral seoloty Faulte and frectures

IA I8 II III Prinary sice
Charecterization

6. Geologic hezards Seisieiey

lique faction

slope inatability Subeidence

keret copoegraphy aroundwater vithdreval nine:

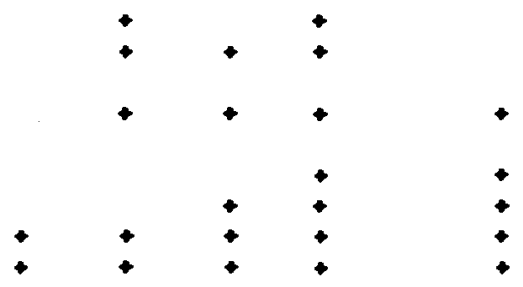

7. Geochemical Meturducion

8. Population Present Treads

9. Land Uce and Resource Davelopment

10. Transportation

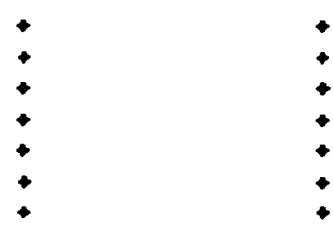

II. Lewe

Federal

State

Local

\begin{tabular}{l}
$\begin{array}{l}\text { Arailable for } \\
\text { Screening }\end{array}$ \\
\hline
\end{tabular}

$\bullet$

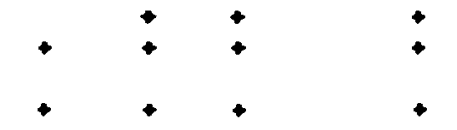

12. Regulations

Tederal

state

Local

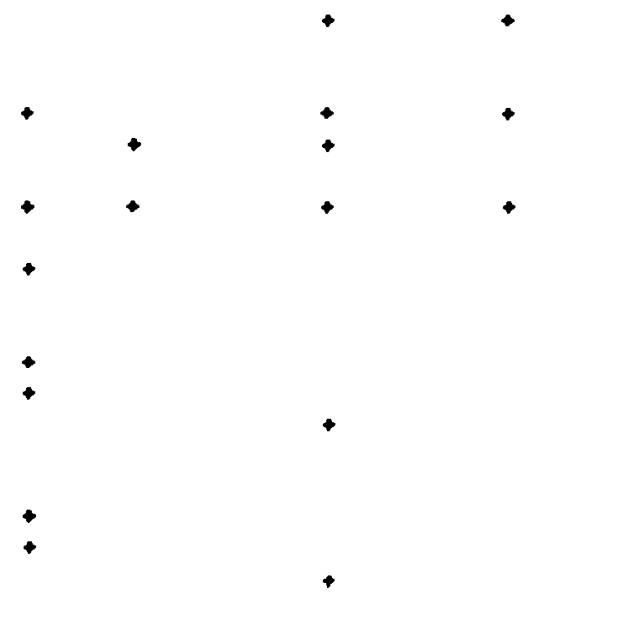




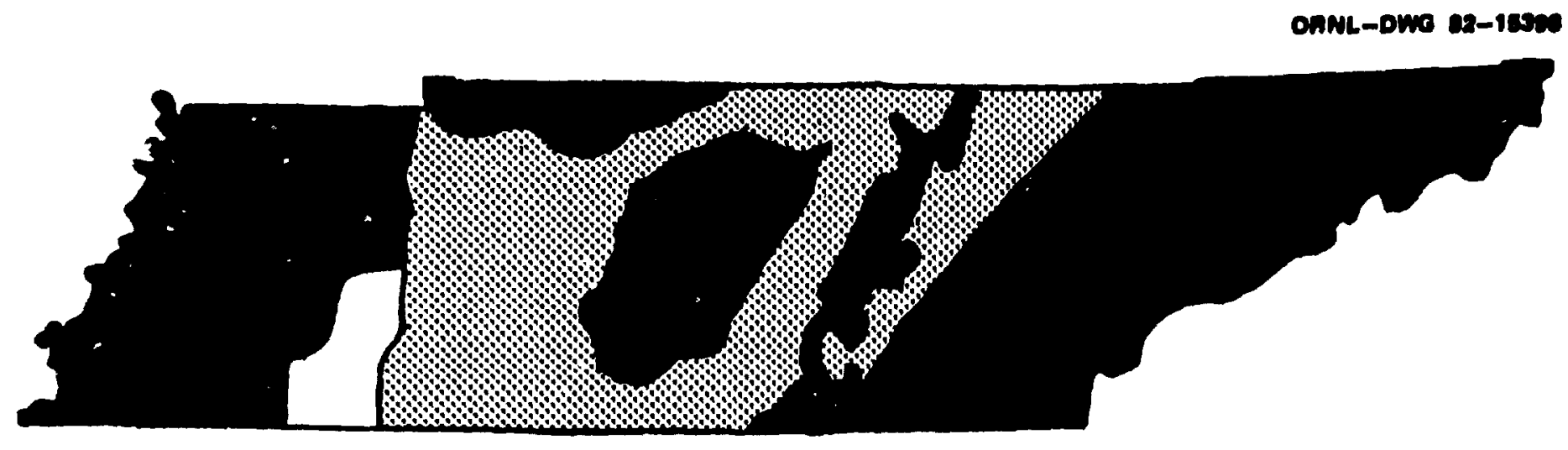

HGH SUITABILTTY

LOW BUITABILITY

INTEAMEDIATE SUITABILITY

Figure 13.2. Composite suitability map for Tennessee. 


\section{TRASPORTATIOA PROGRAM}

\subsection{ImRODUGTOM}

The goal for this task of the Iransportation Technology Center (IIC) transportation program is to evaluate the novenent of comercial nuclear waste from point of generation to final isolation, utilizing the various computer codes already developed for these studies; where existing oodes are not adequate to generate the required information, they will be nodifled appropriately.

Hajor objectives are to complete the logistics support studies as required, upgrade and utilize the full-scale repository logistics nodel, obtain up-to-date shipping cost data, apply the scopg (Shipping Cask Optinization and Paranetric Evaluation) cask design code to current needs, and apply the TBF computer nodels to current needs.

\subsection{PROGRESS}

Technical progress for each of the tasks of this program for the flscal year just ended follows.

\subsubsection{Comercial Waste Transportation Studies (L. B. Shappert, D. S. Joy, J. F. Walker, S. M. Gibson, and P. E. Johnson)}

In the transportation/logistics area, the major task in FI 1982 was the Test and Evaluation Fac1lity (TEP) Logistics Study. A computer program for simulating the flow of packages from waste sources to packaging facilities and TEF sites was developed and made operational three wonths ahead of schedule. Over 200 different TEF runs, each simulatins a different transportation scenar1o, were completed by Bebruary 1982 to assist ONWI In evaluating the BuD facility as a possible waste packaging site. Additional analyses were performed evaluating six hot cells located around the United States as possible 
pecixaging facilities in the TBF transportation systen. A large number of ccnceptual cask designs. were evaluated with the IBP nodel to assist ITC and General Atonic in preparing the Cask Acquisitions Report. Several alternate cask designs were included for each of the proposed waste packages. Several nodes of transportation, including legal and oremelght truck and rail casks, were Included in the study.

Approximately 60 special waps were prepared shouing the highway network in major cities around the country. These maps also included population densities generated from 1980 Bureau of the Census data. This information was used by both TIC and the Department of Transportation in forwulating responses to questions concerning the proposed DOT regulation, EM 164.

The NUS waste managewent model RAKSYM was successfully installed on the ORIL computer system. A number of test cases were run and checked with the data published by NuS. The results indicated that the ORI version was Identical to the program being operated by NUS.

The RAHSYM model is being modified to meet the specific needs for repository transportation scenarios funded by the ITC. The first phase of this modification as cowpleted in FY 1982 and included the incorporation of the latest $\mathrm{DOE}$ spent fuel data base. The projected spent fuel shippirs schedules match the estimated spent fuel storage experiments $(14,4,1)$.

A number of preliminary transportation calculations were performed in support of the ONWI salt repository site recommendation study. Information generated included transport costs, distance traveled, and cask pleet requirements. Seven different salt sites as well as the basalt and tufe sites were included in this analysis. 


\section{$275 / 276$}

The outcrop formations of the remaining physiographic province, the eastern Mississippi Embayment, were then exanined in a wore detailed wanner. The process identified the Coon Creek Foration outcrop band as the best candidate area for further screening for low-level waste sites. inis area is remote from population centers; major transportation syscems are available; the risk of flooding is minimal; sverburden thickness is adequate; erosion resistance is high; the water table is deep; the area is well drained; a relatively impermeable stratum lies above the regional aquifer offering protection from contamination; there are no apparent geologic hazards; and reliable groundwater monitoring and predictability are achievable.

\subsection{PUBLICATIONS}

None.

\subsection{REFERENCES}

None. 
A computerized technique to evaluate the distribution of population densities along a transportation route were developed. Approxinately 54 routes were generated to check the population density assumptions used in the RADTRAN program at Sandia lational Laboratory. A special set of routes was also prepared shoring the population density distribution along both highway and rail routes which would likely be used in transporting waste to a repository site.

\subsection{PUBLICATIONS}

1. J. H. Cashwell and D. S. Joy, "Impacts of Nuclear Materials Flou on Transportation Routing Alternatives," Waste Management '82, Vol. 1, p. 389 .

14.4 REFERENCES

1. Spent Ruel Storage Requirements, DOE/RL-82-1 (June 1982). 


\section{TRU MASTE MAHAGEAERT PROGRAM}

H. H. Pitt

\subsection{INTRODUCTION}

The Comerclal TRW Haste Management Program for FY 1982 consisted of turee tasks:

1. FUETAP Concrete Innobilization - jointly sponsored by the Defensé TRU Waste Managerent Progran and reported In Section 10.

2. TRU Comercial Fuel Cycle Studies - provide quantitative data on TRU waste derived from LWR reprocessing and LMFFBR fab:ication and reprocessing.

3. TRU Isotope Decay Chains - calculate the detalled alpha decay behavior of 38180 topes and present results graphically.

\subsection{PROGRESS}

The progress for each of the tasks in this program for PY 1982 follows :

\subsubsection{FUETAP Concrete Immobilization (L. R. Dole, G. C. Rogers,} J. H. Kessler, and T. M. GIIIIam)

Th1s program was jointly funded by the Defense TRU Waste Management Program and progress is reported in Section 10.2.1.

\subsubsection{TRU Comercial Fuel Cycle Studies (K. J. Notz, W. L. Carter and}

The objectives of this program for PY 1982 were: (1) to provide quantitative data on TRU waste derived from LWR reprocessing, based on the AGNS' (Barnwe11) flowsheet, far realtzicic speut frel burning and ages prior to reprocessing and for realist1c fuel cycle scenarios; and (2) to 
provide qualitative data on TRJ waste derived fron IMPBR fabrication and reprocessing, with attention directed toward identification of generic differences between the LMPBR and LWR cases. Bot.h objectives used projection scenarios out to year 2020, and these were based on the Integrated Data Base (IDB) treatrent (see Section 12).

Detalled flowsheets were prepared for $L W R$ reprocessing, based on the AGNS flowsheet, 1 which 1 s sized for 1500 MTHM/y. All waste streams were quantifled (not just the TRU waste streans) in order to achieve an overall material balance. The Identities of individual waste streams were retained in order to facilicate any future changes or modifications to the processing flows, separation factors, or distribution coefficients. The overall plant was broken down into six major operations: head end, solvent extraction, waste treatment, of f-gas treatment, uranium product recovery, and plutonium product recovery. An overall summary of the waste volumes is shown In Fig. 15.1.

The elemental and Isotopic contents of the waste streams were then calculated, assuming spent fuel 16 y out of reactor wth an average burnup of 25,200 Mwd/MTHM, made up of two-thirds PWR fuel and one-third BWR fuel. The incoming compositions we re calculated using the ORIGEN2 code $^{2}$ and the distributions as a result of reprocessing were also handled using ORIGEN2. The basis for total quantities was the reactor growth projection used by the Integrated Data Base Program ${ }^{3}$ and the reprocessing plant schedule assumed by that program:

$$
\begin{aligned}
& 1500 \mathrm{MTHM} / \mathrm{y} \text { in } 1989 \\
& 1500 \mathrm{MTHM} / \mathrm{y} \text { additional in } 2000 \\
& 1500 \mathrm{mTHM} / \mathrm{y} \text { additt, i in } 2004 \\
& 1500 \mathrm{MTHM} / \mathrm{y} \text { additional in } 2008
\end{aligned}
$$


ONNL OWE S2-57s

\section{maSTE STREAMS}

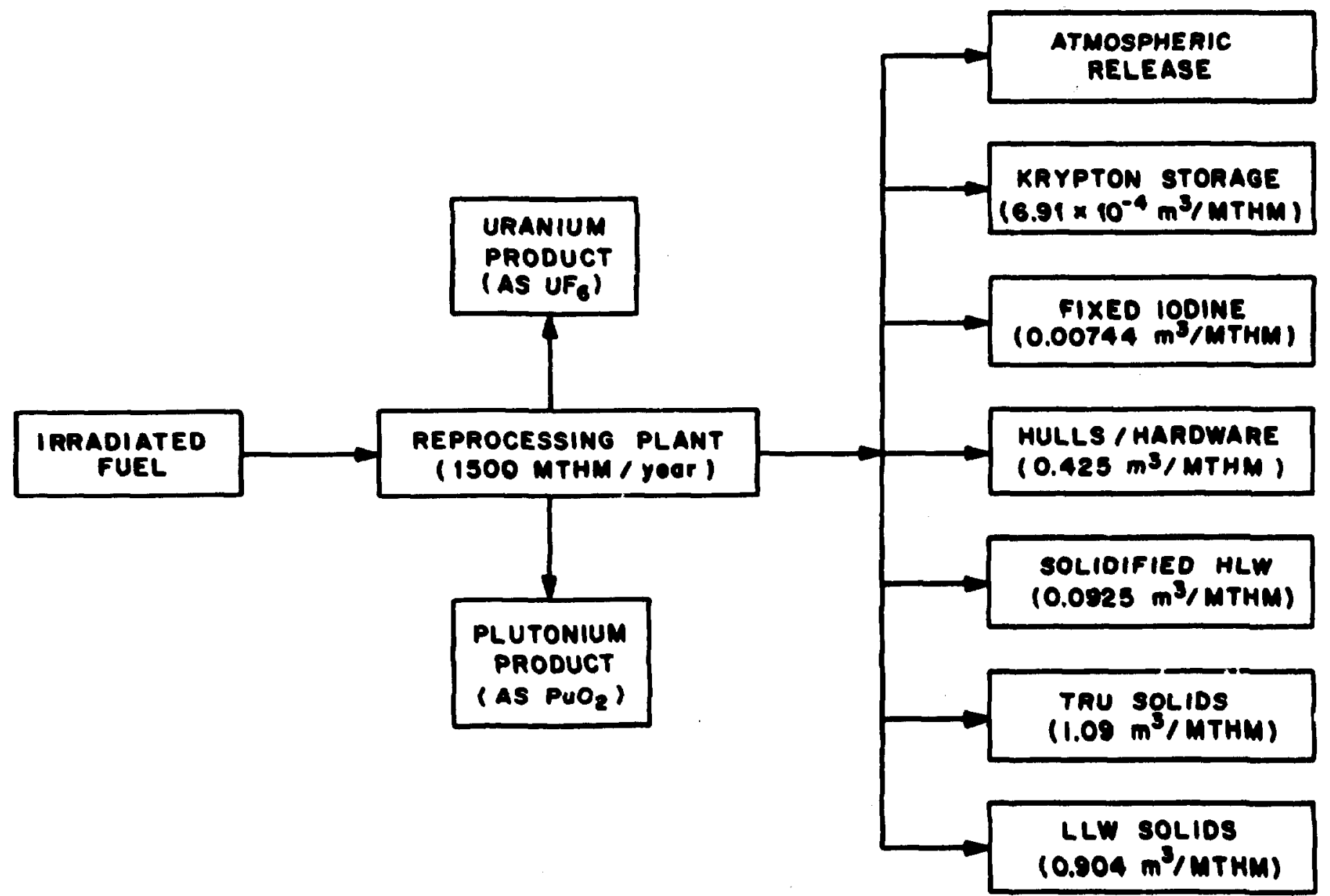

Fig, 15.1. Waste Streams from LWR Reprocessing 
Por the LMPBR fuel reprocessing case, a qualitative analysis was made to Identify generic differences relative to LWRs that will derive fron the different fuel (1.e., Exed $U$, Pu oxide), harder neutron spectrum, and different cladding (sodium-bonded stainless steel). These results and the LUR data will be published in a topical report (see under 15.3).

\subsubsection{TRU Isotope Decay Chaing (K. J. Notz and C. W. Alexander)}

This was a special, short-terw task to provide detalled decay behavior of all TRJ (or potential TRU) 1sotopes. The calculations were done via ORIGBN2 for 38 1sotopes. The detalled results were sumarized on hard copy (a 6-cm-high stack of computar printout for the summary) and then preented graphically, one page per 1sotope, showing the total alpha for each 1sotope, as it decays, including daughters. The time frame covered is from 0.1 year to $10^{6}$ years. Each isotope was "started out" at 100 nCi inftial ativity, efther alpha or beta, as appropriate.

The 38 Initial nuclides included are 11sted in Table 15.1. An additional 21 nuclides appeared in the calculations as daughter products, Table 15.2. Two plutonium 18otopes are show In Fig8. 15.2 and 15.3, 11lustrating several features observed in these plots; e.g., slow decay of a long-1ived parent, in-growth of both short-1ived and long-lived daughters, low Initial alpha activity from a parent that first undergoes a beta decay, and near-term growth of total ilpha activity. This work will be published as a program document (see under 15.3). 
Table 15.1. Initial Muclides Used In this Study

\begin{tabular}{llll}
\hline Ra-226 & $\mathrm{U}-232$ & $\mathrm{Pu}-236$ & $\mathrm{Cm}-242$ \\
$\mathrm{Ra}-228$ & $\mathrm{U}-233$ & $\mathrm{Pu}-238$ & $\mathrm{Cm}-243$ \\
$\mathrm{Ac}-227$ & $\mathrm{U}-234$ & $\mathrm{Pu}-239$ & $\mathrm{Cm}-244$ \\
$\mathrm{Th}-228$ & $\mathrm{U}-235$ & $\mathrm{Pu}-240$ & $\mathrm{Cm}-245$ \\
$\mathrm{Th}-229$ & $\mathrm{U}-236$ & $\mathrm{Pu}-241$ & $\mathrm{Cm}-246$ \\
$\mathrm{Th}-230$ & $\mathrm{~J}-238$ & $\mathrm{Pu}-242$ & $\mathrm{Cm}-247$ \\
$\mathrm{Th}-232$ & $\mathrm{~Np}-236$ & $\mathrm{Pu}-244$ & $\mathrm{Cm}-248$ \\
$\mathrm{~Pa}-231$ & $\mathrm{~Np}-237$ & $\mathrm{Am}-241$ & $\mathrm{Cf}-249$ \\
$\mathrm{~Pa}-233$ & & $\mathrm{Am}-242$ & $\mathrm{Cf}-250$ \\
& & $\mathrm{Am}-243$ & $\mathrm{Cf}-251$ \\
& & & $\mathrm{Cf}-252$ \\
\hline
\end{tabular}




\section{6}

Table 15.2. Additional Daughtier Nuclides Used in this Study

\begin{tabular}{llll}
\hline Bi-211 & Po-210 & At-217 & Ra-223 \\
Bi-212 & Po-211 & Rn-219 & Ra-224 \\
Bi-213 & Po-212 & Rn-220 & Ac-225 \\
Bi-214 & Po-213 & Rn-222 & Th-227 \\
& Po-214 & Fr-221 & \\
& Po-215 & & \\
& Po-216 & & \\
\hline
\end{tabular}


ORNL DWG 82-14532

DECAY OF 100 NFNOCURIES OF PU-238

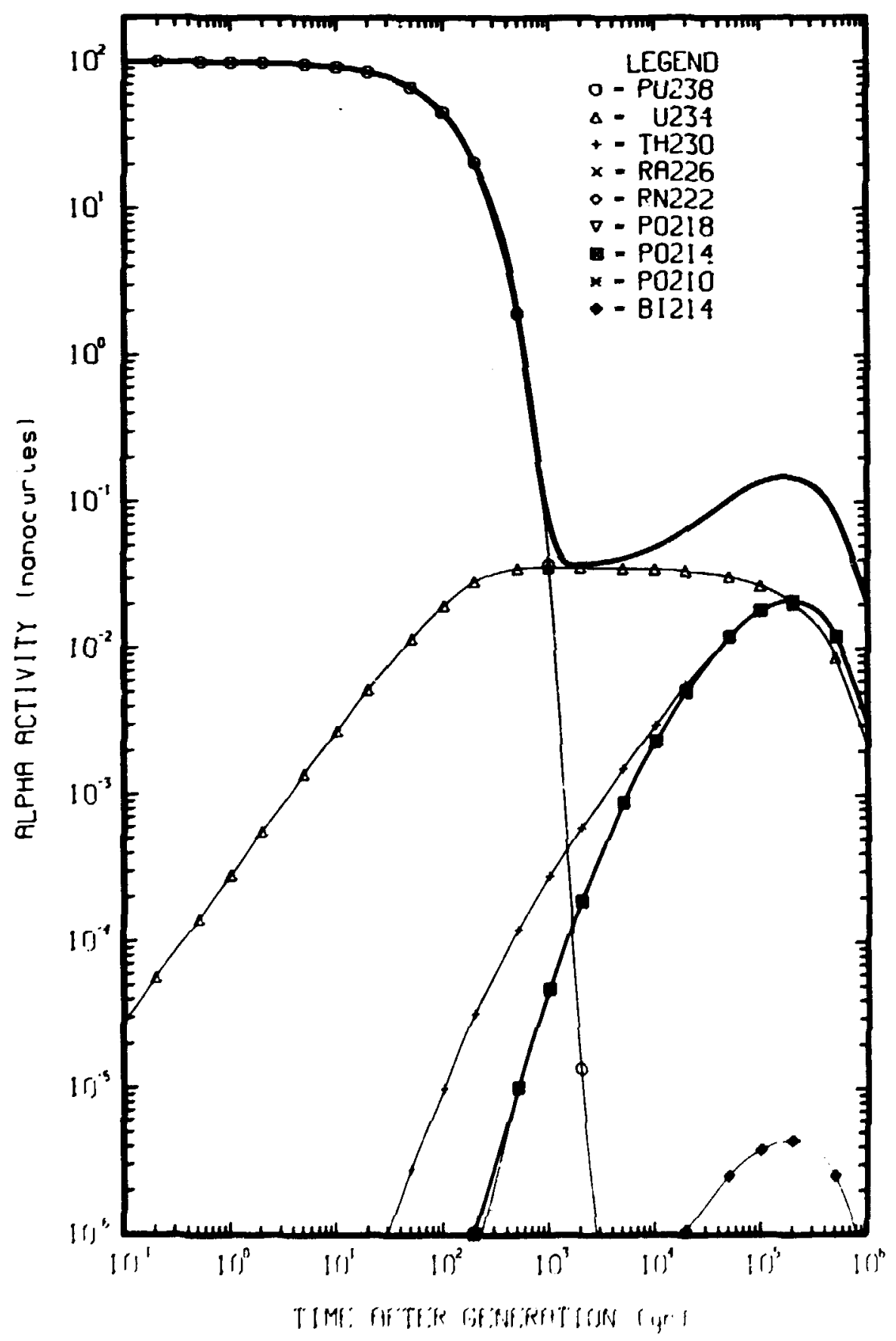

FIg. 15.2. Decay of 100 Nanocuries of Pu-238 
ORNL DWG 82-14535

DECAY OF 100 NANOCURIES OF PU-241

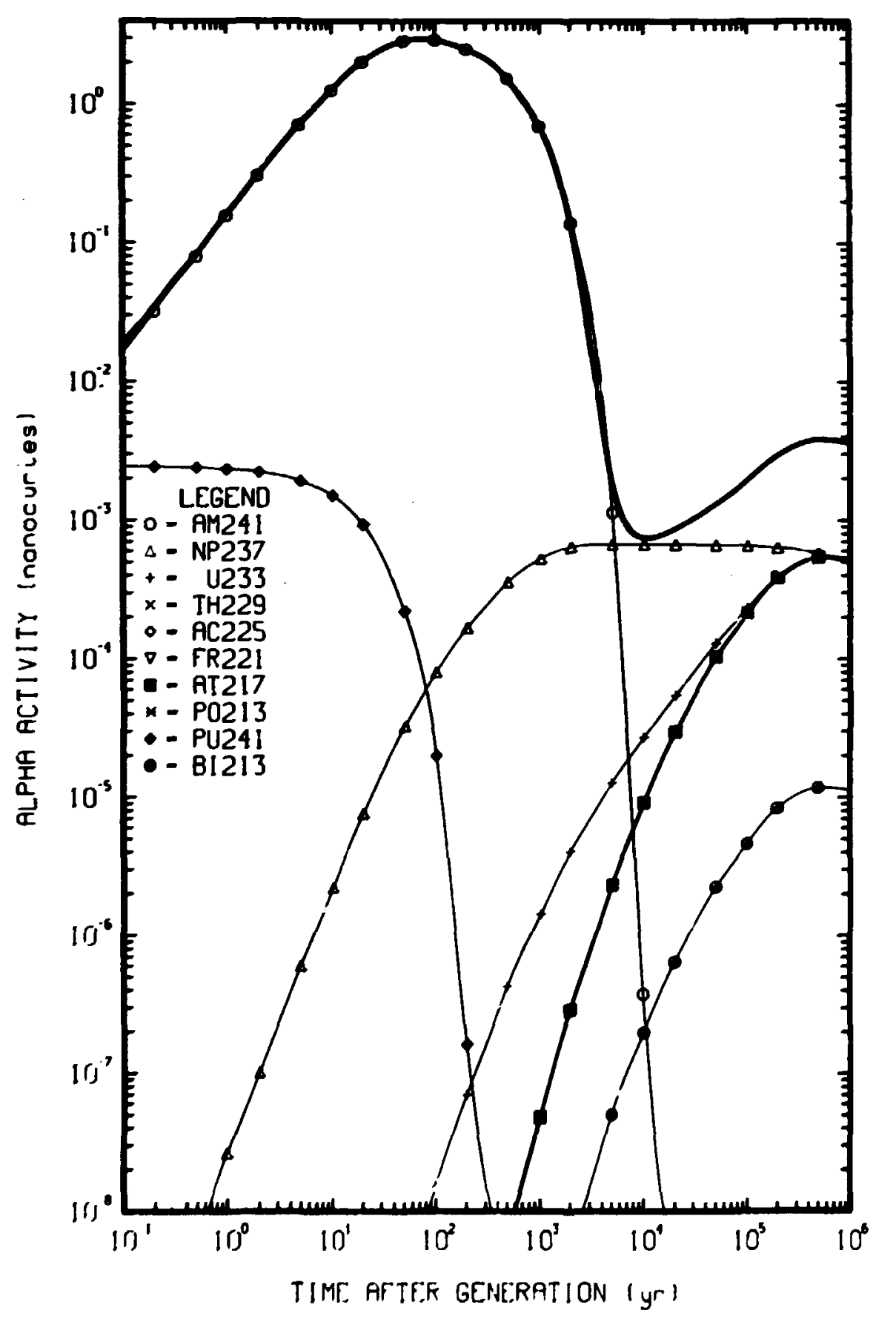

Fig. 15.3. Decay of 100 Nanocuries of Pu-241 


\title{
16. HASTE ISOLATION PROGRAM
}

\author{
S. H. Stow
}

\subsection{INTRODUCTION}

The Waste Isolation Prograw is supported through the Cffice of Nuclear Waste Isolation (OWI) at Battelle Memorial Irstitute in Columbus, Ohio. OWI's efrorts are directed toward the siting of a geologic repository for comercial nuclear waste. ORIL supports this endeavor with a wide variety of tasks.

\subsection{PROGRESS}

Technical progress for each of the tasks of this program for the fiscal year just ended follows.

\subsubsection{Regional Environmental Characterization Studies - Nuclear Haste (J. R. Krummel and S. G. Hildebrand) \\ The objective of this task is to characterize the environment of} the Southern Piedmont region that includes a number of granitic formations which have geologic characteristics potentially suitable for permanent disposal of nuclear wastes. The region will be screened using environmental and geologic criteria in order to identify the most favorable areas for further study. This task supports the ONWI overall goal of providing a significant degree of assurance that highlevel nuclear wastes can be isolated from the biosphere in a safe and environmentally acceptable manner. 
Information contained in the regional environmental characterization report was used to screen geologic formations which have potential as high-level nuclear waste repositories to select formations suitable for further detailed analyses in the area phase of this study. The selection criteria and the screening process was included in the sumary and recomendation report.

16.2.2 Institutional Arrangements for Nuclear Waste Siting The National Waste Terminal Storage Progran recognizes the need to reach consensus not only on the technical issues but on institutional and social issues as well. Our design and testing of possible incentive arrangements for siting hazardous waste facilities mot, therefore, include an integration of economic, institutional, and public participatior. factors into each alternative considered. The objective is the development of a range of evaluated options for inclusion in the consultation and concurrence and other siting processes.

- There are five important findings in this research: (1) the considerable uncertainty that remains in the repository design and siting process' indicates a need for continued research to lessen uncertainty, and flexibility in job training program design as uncertainty is reduced; (2) there are likely to be multiple major factors that need to be involved in job training program design (i.e., the Department of Energy, repository state and local government and their training institutions, labor unions, and the prime contractor and its subcontractors); (3) mechanisms for resolving potential 
conflicts among these major actors need to be developed; (4) program design and implementation decisions need to be documented carefully to protect each program participant's interest; and (5) given the number and diversity of major actors, a clear assignment of responsibilities for program design and implementation must be made.

\subsubsection{Evaluation of Avery Island Coupons (J. C. Griess)}

The objective is to obtain the necessary corrosion data so that various multibarrier waste package emplacement concepts in domal salt can be evaluated.

The tests showed that only carbon steel experienced appreciable attack; maximum penetration during the three-year test was only 200 microns. All other test materials (titanium, Zircaloy-2, Hastelloy C-276, E-Brite 26-1, and T-304L stainless steel) showed no change, except a few isolated areas of attack were noted on E-Brite 26-1 and T-304L stainless steel, none of which exceeded 25 microns in depth.

\subsubsection{Effects of Water in Salt Repositories (C. F. Baes, Jr.)}

It is the objective of this program to predict from experimental and modelling studies those consequences of the presence of water in a salt repository that might compromise the integrity of the repository.

While the generalization of the results is not yet complete, it seems clear that the consolidation of polycrystalline salt down to vnid fractions of approximately 0.05 can be represented adequately by the expression already presentef. Since in a number of tests 
consolidation has been carried almost to completion with continuous expulsion of brine, it appears that the incorporation of brine within crystals is not an mportant trapping mechanism. It should be possible to approximate the permeability of consolidated salt as a function of applied stress, time, and temperature in terms of the expression found for the permeability of crystal interfaces. This permealility probably will determine the final rate of consolidation.

\subsubsection{Salt Model Pillar Studies (T. F. Lomenick)}

The objective of this work is to provide data for the proper design of excavated cavities in rock salt repositories that are candidates for the storage/disposal of radioactive wastes.

Recently a careful examination of the creep records of the long-term tests revealed the existence of episodes of transient creep occurring between periods of steady behavior. The potential importance of these transient creep episodes in repository design and in the verification of computer codes to be used in design justified a more in-depth investigation. Such episodic creep had not previously been reported for salt and consequently a question arose as tc whecher transient episodes reflected material behavior cr some aspect of the test equipment such as sticking and slipping of the load ram or environmental parameters such as temperature or humidity fluctuations in the laboratory.

In order to investigate episodic creep more completely, it was desirable to automate the data acquisition and control the tests to achieve more accuracy and better control. 
The most suitable jystem would include a data acquisition and control system with printing, plotting, and magnetic storage capability controlled by a dedicated micro computer capable of performing data analysis. By using as much software control as possible, such a systen provides a great amount of flexibility for possible future data acquisition and control needs. 16.2.6 Expected Repository Environments for Commercial Hastes,

The primary objective is to provide information in designing experiments and repositories and in licensing procedures based on calculated expected repository environments for the disposal of both commercial and defense high-level wastes and spent fuel in salt formations. The predicted environments or effects include near- and far-field temperature histories, brine chemistry, brine migration rates, fluid pressure histories, and nuclear radiation fields. A series of reports has been issued describing the environments.

16.2.7 Technical Topical Report on Brine Migration (H. C. Claiborne This project was initiated to provide technical data on bi ine migration in a salt repository as input to a licensing topical report. A report was issued describing the technical findings. 
16.2.8 Systen Kodel to Assess Flooding in a Waste Repository (H. C. The objective of this project is to develop the methodology and appropriate computer codes for analyzing the effects of freshwater intrusion into a salt repository for nuclear waste that also has applicability for other geologic media. The methodology to be developed will include the effects of mechanical responses to the mine, the analysis of potential flow patterns in both open rooms and rooms backfilled with crushed salt or other materials and the potential radionuclide concentrations that could result from the assumed flooding scenarios and waste package leaching models.

Salt dissolution mechanisms were examined, and the sequence of solutioning was divided into two phases--essentially an isothermal phase during flooding and after filling and a heatup phase causing additional dissolution of salt. Models for the two phases were identified. The literature on leaching of radionuclides was examined and appropriate models were identified. Evaluation of the experimental data on the permeability of crushed salt as a function of time while being stressed was completed. Considerable progress was made on developing a computer code for simulating the flooding process. This code (REFS) will be based on the existing code HYTAQ.

16.2.9 Sensitivity and Uncertainty Analysis Methods Development The objective of this task is to develop the GRess computer language to automatically calculate the sensitivities of waste 
respository model performance with respect to model data. Results of this task will be central to the developwent of a comprehensive methodology for sensitivity and uncertainty analysis for waste repository design licensing. The development of the GRESS language will autonate the application of adjoint sensitivity theory to large scale risk analysis problems. It will allow sensitivities to be produced for all model data thereby focusing licensing analysis on the most important parameters and their uncertainties.. Developments in this task will make adjoint sensitivity theory competitive with statistical uncertainty methods in applicability to large scale models. The inherent advantage of adjoint methods in study completeness will then allow a comprehensive sensitivity and uncertainty analyses to be performed on a waste disposal design for licensing.

This task began in June 1981 with the development of a demonstration version of the GRESS automated language approach to adjoint sensitivity analysis. The program was halted September 30 , 1981 with the cumpletion of GRESS Version A. After an evaluation of adjoint sensitivity methods by OWHI in April 1982 plans were made for full scale development and implementation of this approach for repository design licensing. This overall program will begin October 1 , 1982. The small cask described in this report was begun in the last quarter of FY 1982 to evaluate the feasibility of demonstrating a fully developed version of the GRES language on the large scale hydrology modeling code SWENT. 


\section{6.? PUBLICATIONS}

D. J. Bjornstad and R. Johnson, "Payments in Lieu of Taxes Between Federal and Local Govermments in the Siting of Federally-Owned Waste Isolation Facilities," Review of Regional Studies, v. 12, 1982.

D. J. Bjornstad and G. Coss, "Issues in the Use of Payments in Lieu of Taxes to Provide luclear Waste Facility Siting Incentives, Radioactive Waste Kanagement, December 1981.

B. Beyerlein and H. C. Claiborne, "The Possibility of Multiple Temperature Maxima in Geologic Repositories for Spent Fuel from Nuclear Reactors," Jour. of Heat Transfer, February 1982.

S. A. Carnes, et al., Inceatives an: the Siting of Radioactive Waste Respositories, ORNL-5880.

S. A. Carnes, et al., "Framework for Evaluating the Utilit, of Incentive Systems for Radioactive Waste Repository Siting, Waste Management, 1982, Vol. 2, Roy G. Post, Ed. (Tucson: University of Arizona, 1981)

S. A. Carnes et al., "Incentives and Muclear Waste Siting: Prospects and Constraints," submitted to Energy Systems and Policy 16, July 1982 .

H. C. Claiborne, The Efficacy of Backfilling and Other Engineered Barriers in a Radioactive Waste Repository in Salt, ORNL/TM 83\%2.

E. D. Copenhaver et al., "Framework for Evaluating the Utility of Incentive Systems for Radioactive Waste Repository Siting," In Advances in the Science and Technology of the Management of High-Level Nuclear Waste, Peter L. Hofman, ed. (Columbus, Ohio: Office of Nuclear Waste Isolation, in press). 


$$
289 / 290
$$

\subsection{PUBLICATIONS}

W. L. Carter, P. J. Johnson, and R. H. Rainey, Quantities and Characterlstics of Transuranic Hastes fron Comercial Fuel Cycles, ORAL/TH-8580 (to be published).

C. W. A'exander and K. J. Notz, Alpha Decay of 38 Nuclides, ORnL/NFW-82/32 (to be published).

\subsection{REFERENCES}

1. W. H. Carr, Estination of the Nuclear Haste Types, Characteristics, and Quantities fron the Barnwell Nuclear Fuel Plant, B 512-09600R (May 1982).

2. A. G. Croff, A User's Manual for the ORIGEN2 Conputer Code, ORNL/TM-7175 (July 1980).

3. Spent Fuel and Radioactive Waste Inventories, Projections, and Character1stics, DOE/NE-0017-1 (October 1982). 
E. D. Copenhaver et a1., "Framework for Evaluating the Utility of Incentive Systems for Radioactive Waste Repor,itory Siting," NWTS Program, DOE/NWTS-15.

L. 0. Gilpatrick, C. F. Baes, A. J. Shor, and D. Canonico, The Permeability of Salt Crystal Interfaces to Brine, ORNL-5874.

L. O. Gilpatrick, A. J. Shor, C. F. Baes and D. Canonico, Initial Report on the Permeability of Salt Grain Boundaries, ORNL/NFW-81/32.

J. C. Griess, Evaluation of Corrosion Damage to Materials After Three Years in the Avery Island Salt Mine, ORNL/TM-8351.

G. H. Jenks and H. C. Claiborne, Brine Migration in Salt and Its Implications in the Geologic Disposal of Nuclear Waste, ORNL-5818.

J. R. Krumme 1, M. Nungesser, C. Hunsacker, and C. Tucker, Regional Charactorization of the Solthern Appalachian Crystalline Region, ONWI-343.

T. F. Lomenick and J. Russel1, Measurement of Long Term Creep in Salt Pillars, NWTS Program, DOE/NWTS-15.

L. Rickertsen, L. Arbital, and H. C. Claiborne, Expected Near-Field Thermal Environments in a Sequentially Loaded Nuclear Waste Repusitor: in Salt, ORN/TM-8083.

L. Rickertsen, O. Misplon, and H. C. Claiborne, Expected Very-Near-Field Thermal Environments in a Salt Repository for Advanced Spent Fuel and Defanse High-Level Waste Package, ORNL/TM-8109.

\subsection{REFERENCES}

None. 


\title{
17. SURPLUS FACILITIES MANACEMENT PROGRAM
}

\author{
J. H. Cosbs
}

\subsection{INTRODUCTION}

This is the second of two programs that are concerned with the management of surplus facilities. The facilities in this program are those related to commercial activities, which include tile three surplis experimental and test reactors [(MSRE, BRE-2, and the Low Intensity Test Reactor (LITR)] and seven experimental loops at the ORR. The program Is an Integral part of the rurplus Fac1lities Management Program, which Is a national program administered for DOE by the Richland Operations office. Objectives of the program are to provide for survi:ilance and maintenance of surplus radfoactively contaminated DOE facllities awaiting decommissioning in order to assure safe conditions and to implement a structured decommissioning program to accomplish disposition of all surplus DOE-owned facilities. The decommissioning operations are supported by financial estimating, planning and scheduling, engineering, and technology development activities.

\subsection{PROGRESS}

Technical progress for the task of this program for fiscal

year 1982 follows.

17.2.1 Commercial Surplus Facilities Survelilance (R. V. McCord and

This task includes survey and inspection of surplus faclities on a regular basis, collection and analysis of samples from waste streams, 
replacement of exhaust air filters on a regular besis, and matntenance of facilities as Indicated by procedures and results of inspections. Routine survelllance and naintenance activities were continued at several facllities. The annual fuel salt reheat and coutalnnent leak test was conpleted at the MSRE. A leaking shield plug at the ORR north bean hole BN-1 was replaced with a new plug. This facility had previously been used for the witen salt loop experinent. Excess com ponents and exposed plolng at the LITR were removed and disposed of as solid waste. A radiological survey of the HRE facilities was completed except for retrieval and analysis of subsurface soll cores.

\subsection{PUBLICATIONS}

None.

\subsection{REPERENC_3}

None. 


\section{URANIUM MILL TAILINGS PROGRAM}

\section{J. H. Coobs}

\subsection{INTRODUCTION}

The Oranium Mill Tallings Remedial Action Progran (UMTRAP) is a national program dedicated to the cleanup and/or stabilization of 25 abandoned all tallings sites in ten states. The progran is adminlstered for DOE by the Albuquerque Operations Office. Progran participation by ORN during FY 1982 consisted of two snall tasks: one on evaluation of liners for tallings piles and a second on information support for all aspects of the program. The liner technology task was Intended to address the long- and short-terw changes in properties of IIner materials, but the scope of work was limited to an evaluation and assessment of grouted In-situ liners as a remedial action alternative. The second task provides information support to the program by maintaining a computerized data base, conducting searches of the data base as a service to users, preparing an annotated blbllography covering additions to the data base, and providing technical support at conferences.

\subsection{PROGRESS}

Technica! progress for ea :h of the tasks for this program for flscal year 1982 follows.

18.2.1 Liner Evaluat lons for Uranlum Mill Tallings (T. Tamura and Th1s task was responsive to a request from the UMTRA Program office to prepare an assessment of the possible utilization of grouted in-situ 
liners as a reaedial action alternative. The work was carried out by collecting and evaluating Inforation on grouting technology obtafned through literature searches and from discussions with experinentalists and practitioners oi greuting. This information and an assessment thereof were documented In a draft report that was subnitted for review and will be published early in FY 1983. The report discusses grouting equipment and procedures and the characteristics of grouts and their compatibility with mill tallings piles, and presents an economic assessment of grouting as a remedial action and recommendations for Implementation of the method.

\subsubsection{UMTRAP Information Support (P. T. Owen)}

The Remedial Action irogram Information Center (RAPIC) was supported folntly during FY 1582 by UMTRAP, by the Surplus Facilitfes Management Program, and by the Formerly Utilized Sites Remedial Action Program, thus enabling the center tc perform a full spectrum of Information support activities. The data base was expanded by abstracting and indexing 1037 documents, and 502 information requests were answered. Abstracting continued unt 11 . June when preparations for the publication of volume three of the blbllography were begun. The blbllography was published and 971 coples were distributed. A revised distribution list for RAPIC publications is being maintained as a separate data base.

Information support at conferences consisced of attendance by two representatives of RAPIC at the International Symposium on Management of Waste from Uranlum Mining and M1lling, held May 10-14, 1982, in 
REMEDIAL ACTIONS PROGRAM 


$$
307 / 308
$$

Albuquerque, New Mexico. RAPIC staff manned an Inforation booth, wich Included a display of RAPIC and UMTRAP Ifterature, a poster exhibit on RAPIC and UMTRAP activities, and video tapes for individual viewing on uranium nfll tailings and decommissioning technologies. Computerized literature searches and copies of RAPIC publications were provided to conference attendees upon request.

\subsection{PUBLICATIONS}

T. Tamura and H. J. Boegly, Jr., In-Situ Grouting of Uranium Mill Ta111ngs P1les - An Assessment, ORNL/TM-8539 (In publication).

P. T. Owen et al., Nuclear Facility Decommissioning and Site

Remedial Actions: A Selected Bibllography, Vol. 3, ORRL/EIS-154/V3

(September 1982).

18.4 REFERENCES

None. 
19. FORYRRLY UTILIZED SITES REARDIAL ACTIONS PROGRAY

\subsection{IMIRODUCTION}

Low-level radioactive containants associated wth past activities at the Middlesex S pling Plant. Site are currently stored on a spectally designed and constructed asphalt pad at the south end of the facility. Although this wans of contalment provides an Interin solution to the problea, it is apparent that plans for the ultinate disposition of the mastes nst be developed. One of the wot prodsing alternatives for the permanent disposal of these wastes as well as FUSRAP wastes at other sites is in situ stabilization. This report sumarizes data on the critical elements of geology and hydrology at the Hddlesex site and outlines a plan for their possible explacenent.

\subsection{PROGRESS}

Technical progress for each of the tagks of thls progran for this fiscal year just ended follows.

\subsubsection{Stabilization Studies at Middlesex, New Jersey Sampling Plant}

The former Mddlesex Sampling Plant S1te (MSPS) occuples a 9.6-acre tract adjacent to the New Jersey Central Rallroad and Mountaln Avenue within the Borough of Middlesex, New Jersey. The facllity was formerly used in the 1940's and 1950's for the processing and storage of uranim and thortur ores, but 18 currently uttlized as a site for the storage of low-level radioactive residues that resulted from the cleanup of surrounding properties. The U.S. Departient of Energy ouns the facility which 1s one of the first sites to be Investigated and to undergo remedial-cleanup masuree under the 
Formeriy Utilized red/ABC Sites Remedial Action Progran (FUSRAP). National Lead of Ohio, Inc. served as the contractor responsible for the two-phase cleamup operations during 1980-81; since then, managent responsibilities for the site have been transferred to Bechtel Maticnal, Inc. as the Progran Management Contractor far FisRaP. The general Hiddesex-Piscataway area of Hew Jersey 18 situated wthin a geologic-physiographtc region known as the Triassic-Newark Basin. It is one of a muber of simlar elongate basins which are orfented northeast-southwest and extend from Nova Scotia on the north to northern Florida on the south. These basins are developed in both the crystalline-rock (1gneous and netamorphic) terrane of the Appalachian Mountains belt (PIedmont) and beneath younger sedimentary units of the Atlantic Coastal Plain. Most of these basins are known to be bounded by steep faults on at least one side and filled with non-marine sedimentary strata of Triassic to Jurassic age. Many of the rock unfts are red; associated volcanic lavar (1.e., Watchung basalts) and shallow intrusives (i.e., Palisades diabase) are found in many areas.

Northeastern New Jersey was also glactated during the major glacial age, or Plefstocene. AS a result, 1rregular, linear deposits of glacially-derived and glacially-transported sediment are found to the north of the Middlesex-P1scataway area. These so-called morainic deposits also provlded a source of sediments which glacial meltwater redeposited out in front of the woraines. These rewashed, water-1ain segments are cermed outwash deposits and they typlcally overlie the red-colored bedrock of the Newark Basin in this area. 
Solls found throughout this part of hew Jersey are derived from the blochenical weathering of both the Triassic bedrock and these unconsolidated glacial-outwash sediments. In addition to the thin veneer of glacial outwash and soils (in the agronontc sense), man's activities have added backfill (soil in the engineering sense) and other construction aterials (crushed stone or aggregate, cinders, asphalt, etc.) in certaln localized areas.

The MSPS proper is underlain by a thin covering of artificlally-added construction merials, soil, and silty glactal sediments, all of which overlie at shallow depth a bedrock unit known as the Brinswick Shale. As indicated by the boreholes drilled during past studies, the depth to this red-colored bedrock unit varied from 3.0 to 7.5 feet throughout the MSPS.

Based upon the borehole data collected onsite and regional Information about the Brunswick Shale in adjacent areas, red shale (or midstone) is the principal rock type in this geologic formation. Although sandstones and siltstones are found in this formation elsewhere, neither of these 11thologies were encountered in any of the five deep boreholes at the MSPS. Thus, Information collected to date Indicates that red shrie is the only rock type present within the shallow ( $<50$ feet) bedrock at the site.

Immediately overlying this red shale is a thin (<1 foot) zone of weathered, disaggregated shale. Where the veneer of glacial sediments 1a absent, this zone of weathered shale, especially at its more shallow positions, appears as a red clayey silt (or sllty clay) containing fragments of red shale. Under the current Soll 
Conservation Service designation, this thin, shale-derived soll is called the Reaville Serles.

Where not fractured or jolnted, the shale of the Brunowick Shale Is deep red, compact, silty, and impermeable. Cores recovered fron the deep boreholes onsite did, however, reveal zones of green coloration, white calcareous coatings (suggestive of secondary dneralization filling foint openings), and black carbonaceous films as uepartures from the description above. Another exception was provided by borehole DOE-6A, which apparently penetrated a 9-foot zone of fractured-jolnted shale. Hydraulfc testing confirmed the presence of this porous-permeable interval.

Discovery of a zone of fractured-jointed shale in the bedrock at MSPS was not unexpected. To the north and northwest, the Brunswick Shale exhibits joints in outcrops and is also interrupted by the three Watchung Yountain lava flows (Van Houten, 1969). Elsewhere, the Brunswick Shale 18 an aquifer from which potable ground water 18 obtained; the occurrence and movement of th1s ground water 18 clearly associated with the presence of foints within an otherwise permeable sequence of fine-grained rock types (Vecchioli, Carswe11, and Rasabach, 1969). A simf lar relationship between ground-water ocarrence and secondary porosity within the Brunswick Shale as caused by jolnting has been Identified In Bssex County, New Jersey to the northeast of the M1ddlesex-P1scataway area (N1chols, 1968). Roy P. Weston, Inc. (1980) also Indicated that ground water 18 obtained from fracture porosity wthin the Brunswick Shale In western Middlesex County. Several water wells within a two-nlle radius of the MSPS are 
belleved to produce ground water from fractures-joints in the Brunswlck Shale (Pord, Bacon, and Davis, Otah, Inc., 1979). In fact, a greater density of boreholes drilled into this bedrock unit at or near the MSPS would probably indicate the presence of additional zones of fracturing and jointing.

Purthernore, the Brunswick Shale 18 gently Inclined within this part of Kew Jersey. The unit as a whole 18 tilted so that it dips toward the northwest.

In an early 8011 survey (Holman and Junk16, 1953), portions of the tract occupled by the MSPS are mapped as having soll derived fron thin glacial-outwash sedinents that overlie the red Brunswick Shale. In several of the boreholes (Doe-2, 3, 3-A, 4, 4-A, 6, 6-A, and 8) drilled by Roy F. Weston, Inc, a thin (1/2 - 2-1/2 feet) zone of gray clog-rich silt is present and may well represent this glacial parent material and/or solla Given the amount of past construction activties, Including grading, backfiling, and asphalt paving, it is difficult to clearly establish the above relationship.

By ut1lizing the 20 boreholes drilled at the MSPS, weekly water-level measurements were taken during June and July of 1980 and compared against precipltation records from the nearby Newark International AIport (Roy F. Weston, Inc., 1980). Several slug tests were also perfc swed in selected horeholes. These data are the principal means by which the nature of the ground-water hydrology at the MSPS has been established.

In summary, the geologic and hydrologic setting of the MSPS is rather stralghtforward. The sice exhibits a rather gentle topography developed upon a thin veneer of solls, artificial fill material, and 
weathered ahale which collectively overlles a shale-do-inated bedrock fornation called the Brunswick Shale. the latter is present throughout the site at shallow depth, contains at least one and possibly more zones of higher permeablity (or transulssivity if viewed from a hydrologic vierpoint) caused by jointing, and dips toward the northwest. Data collected prior to renedial-action measures and on-site construction Indicated the presence of a shaljow ground-water systen within the overlying unconsolidated materials and a deeper systew wthin the bedrock. Some modification to the entire hydrologic regine at the MSPS has resulted from the several construction activities associated with Installation of a disposal pad.

A generalized plan for an in situ stablization program might Include these elements:

1. Excavation outside of the southern portion of the area to a depth of a few feet below grade over several acres to remove any on-Bite contaminated soll and to acquire adequate natural soll (uncontaminated) for admixing.

2. Backfiling this initial excavation wth a 1- to 2-ft layer of additive material (natural and/or artiftcial) which has been demonstrated to have a high level of Ion-exchange capacity with particular regard to the radioactive specles within the wastes.

3. Spreading next a thin (6-12 in.) layer of natural soil materlal over the sorptive buffer layer, followed by alternating layers of waste admlxed with the natural soll (and possibly vartous additives) and soll adndxed only 
additives. In other words, the waste materials would be contained in a thin-layer stratification sequence.

4. Lateral extension of this approach would be made in order to acconmodate all the waste materlals currently stored on the pad in the southern part of the area and the contaninated soll under that area. If necessary, a part or all of the southern portion of the area could be utilized so that the resulting layered, In situ stabilized sequenca produced as low a topographic increase as possible.

5. Contouring, drainage diversion structures, and other runoff control measures would be Incorporated to Insure that surface dratnage presented a IIInimal concern with regard to the in situ waste system.

6. A cover of 1 to 2 foot of compacted clay would be added over the ipper part of the in situ sequence to significanty lessen the amount of water avallable for infiltration.

7. Addition with appropriate grading, fertilization, seeding, and mulching of a vegetative cover (grass or other shallow-root plants) wuld constitute the final step in completing this in situ stabilization approach.

\section{3 PUBLICATIONS}

T. F. Lomenick, In Situ Stabilization at the Former Sampling Plant S1te, Middlesex, New Jersey (In review). 


\section{4 :EFBRENCES}

Ford, Bacon and Davis, Otah, Inc., 1979, Englneerling Evalrdtion of the Former Middlesex Saipling Plant and Assoctated Properties, Hidlesex, New Jersey: Salt Lake CIty, Dtah, Final Report, FBDD-230-001, prepared for the U.S. Department of Energy. Envi ronmental Analysis of the Former Middlesex Sampling Plant and Associated Properties, Middlesex, Hew Jersey: Salt Lake City, Utah, Final Report, FBDU-230-001, prepared for the U.S. Departwent of Energy (1979).

W. W. Holman and A. R. Jumikis, "Englneering Soll Survey of New Jersey-Middlesex County," Rutgers University Bureau EngIneerIng Research Report No. 10 (1953).

National Lead of Ohfo, Inc., Phase I Remedial Action of Properties Assoclated with the Former Middlesex Sampling Plant Site: CIncinnat1, Ohio, Project Report NCRO-006EV, prepared for the U.S. Department of Energy (1982).

W. D. N chols, "Ground Water Resources of Essex County, New Jersey," New Jersey Division Water Resources Special Report No. 28 (1968).

F. B. Van Houten, "Late Triassic Newark Group, North-Central New Jersey and Adjacent Pennsylvania and New York," In Seymour Subitzky (ed.), Geology of Selected Areas in New Jersey and Eastern Pennsylvanta, and Guldebook of Excursions: Geol. Soc. America Gu1debook, At lantic City Meetings, pp. 314-47 (1969).

J. Vecch1ol1, L. D. Carswell, and H. F. Kasabach, "Occurrence and Movement of Ground Water in the Brunswlck Shale at a S1te near Trenton, New Jersey," U.S. Geol. Survey Prof. Paper 650-B, pp. B154-B157 (1969). 
Roy F. Weston, Inc., Hydrogeology of the Pormer Middlesex Sampling Plant Site, Middlesex, New Jersey - West Chester, Pennsylvania," PInal Report prepared for Oak RIdge National Laboratory. 
CONVENTIONAL REACTOR PROGRAM 
20. THRBE MILE ISLAND PROGRAM

A. P. Malinauskas

\subsection{INTRODUCTION}

Activities associated with the Three Mile Island (TMI) Progran were of two types. One involved providing technical review and guidance for specific recovery efforts at $\mathrm{NL}$, whereas the second was concerned wore directly with providing technical assistance to recovery operations through detalled analyses and experimental activities. The work was divided Into four elements: Task I - coordination of and participation in the operation of the Technical Advisory Group (TAG) for the cleanup of aqueous streans at TMI; Task II - participation in the Technical Assistance and Advisory Goup (TAAG) on TMI operations; Task III - chemical development and other technical support to TMI recovery operations; and Task IV - deveiopment of inorganic sorbents for the decontamination of aqueous streams. At the program review that was conducted approximately mid-fiscal year, it was decided to curtail the Task IV activities in favor of studies of more urgent problems.

\subsection{PROGRESS}

Technical progress for each of the tasks of th1s program for the flscal year just ended follows.

\subsubsection{Technical Advisory Group Activities}

The TAG activities were concerned primarily with the prediction and subsequent analysis of the operation of the Submerged Demineralizer System (SDS) for cleanup of the high-activity-level warer in the containment 
building and for the adaptation of the SDS to decontaninate the reactor coolant system (RCS) water.

A number of lesser activities involved considerations of the following problens: (1) processing of the containment building water head;

(2) elution of radiocesium from an in-containment decontanination experiment utilizing a pushcart lon-exchange colum; (3) the disposition of slightly contaninated anmoniun hydroxide solution; (4) wethods for the removal of chloride from RCS water; (5) the use of sodium nitrate or nitrate to suppress radiolytic hydrogen production in SDS ion exchange columns; (6) the employment of decontanination reagents in the reactor bulding and their potential effect on SDS operation; (7) the need to design a canal/reactor vessel cleanup systen for use in defueling; and (8) analysis of concentration changes during feed/bleed of RCS water to ascertain the extent of mixing in the primary system.

\subsubsection{Technical Assistance and Advisory Group Activities}

Unlike TAG, whose activities are generally restricted to matters Involving aqueous stream cleanup, TAAG considerations extend to all TM: recovery efforts. The Goup, in fact, played a mafor role in the axial power shaping rod motion tests and the "quick look" video camera insertions during the past year. TAAG reports formally to the TMI-2 Plant Manager after each series of deliberations. These reports are avallable through the EG\&G Technical Interpretation of fice at TMI.

\subsubsection{Technical Support Activities}

The technical support activities generally consist of a number of ad hoc operations of relatively short duration, which are conducted to resolve 
specific problens that arise during the recovery efforts. The work is, however, generic in the sense that similar problens would be encountered in any light water reactor (LWR) accident recovery effort. During this fiscal year, the technical support work consisted of the following activities.

\subsubsection{Expected Source Terms During Defueling Operations}

This activity consisted in convening an in-house peer review group to eval-rate a document entitled "Estinated Source Term for Radionuclides and Suspended Particulates During TMI-2 Defueling Operations." The group concluded that the source tems were grossly overestiated. A second draft of the document is currently in preparation.

\subsubsection{TMI Cricicality Safety Support Study}

Calculationai criticality studies were conducted on various postulated mixtures of fuel pellets, fuel "fines," water, and boron to develop information that is required in assessments of proposed recovery procedures. The results of the studies were transitted in a report entitled Nuclear Critlcality Safety Studies of Interest to TMI--2 Recovery Operations, ORNL/CSD/TM-193 (October 1982) by J. T. Thomas.

\subsubsection{Steam Cenerator Tube Corrosion}

Inadvertent injection of thlosulfate into the TMI-1 RCS resulted in extensive stress corrosion cracking of the steam generator tubes. Assistance was provided to General Public Utilities at U.S. Department of Energy request to ascertain the nature and cause of the corrosion. Guldance In the development of a research program almed both at Identifying the specific cause of the cracking and at developing a means of preventing nonthrough-wall cracks from propagating was also provided. 


\subsubsection{Elution of Pushca-. Zeolite}

In order to remove the pushcart colum that was installed in the MII-2 containment building for use In prelininary testing of the SDS flowsheet, It was advantageous to decontaminate the zeolite that was eaployed in the test and was thereby loaded with radiocesium.

An experimental study was conducted to develop an elutriant which

would introduce no foreign chenicals into the containnent building and moreover could be used in a straightforward manner. The use of cesiun borate solution was shown experinentally to provide a viable solution to the problem.

\subsubsection{Wethods for Chloride Removal from RCS Water}

A series of experiments was conducted to deternine the capability to reduce the concentration of chloride ion in the RCS water fron the reported 0.7-2 ppr level to a level of $0.1 \mathrm{ppm}$. Materials selected for testing included silver-loaded zeolites, borate-form anion exchange resins, silverloaded cation exchange resin, and silver metal powder. The silver-loaded zeolites and the silver-loaded cation exchange resin were shown to be attractive candidates for chloride removal, provided problems associated with 81lver chloride precipitation could be overcome.

\subsubsection{Thermal Pallure Mechant8ms of Self-Powered Neutron Detectors}

A serles of experiments was conducted whth four objectives in mind: (1) determine if self-powered neutron detectors (SPNDs) can fall through Imply thermal-activated processes; (2) determine the temperature or temperature range of fallure; (3) determine the thermal 11mits for thermal 4.t?ration of a SPND; and (4) postulate a fallure mechantsm for the SPNDs 
at MII. The tests, which were conducted to temperatures of $1300^{\circ} \mathrm{C}$, led to the conclusion that the thermal response of the SPND was dontnated by effects to the electrical leads. Although some chenical interaction between the leaks and the electrical insulation was noticed, the tests to $1300^{\circ} \mathrm{C}$ did not lead to shorting of ather cable or sensor.

\subsubsection{Sorption Rate Studies}

Studies were made of the contact time required for each of two speclally selected zeolites to absorb elther cesiun or strontiun from solutions simulating those to be expected to result from MII-2 reactor building surface washdown operations. Results of the tests demonstrated a clear superiority of one of the zeolites over the other for early sorption of both cesium and strontiun. The resulis also indicated no pronounced dependence upon tenperature over the range $24-54^{\circ} \mathrm{C}$ for the preferred zeolite.

\subsubsection{Analysis of RCS Hater and Contalngent Bullding Sludge}

A sanple of RCS water that was taken at 0700 hours on June 14, 1982, was analyzed chemically. Boron 1sotopic analysis Indicated the naturallyoccurring distributior; this resolved a question that had arisen prior to the axial power shaping rod motion tests. Uranlum lsotoplc analyeig Ind1cated $2.347^{235} U$ and $97.597{ }^{238} U$ at a uranium concentration of $1.9 \times 10^{-4}$ $\mu g / m L$. Other species analyzed were at more or less expected concentration 1eve1s. The carbonate concentration was found to be 0.04 molar, which tends to confirm the likelihood that fission product strontium that escaped from the fuel during the accident subsequently precipitated as the carbonate. 
A sample of containment bullding sludge is currently undergoing chenical analysis. Prelininary results using spark source nass spectronetry Indicate very high concentrations of copper, boron, sodiun, aluginum, and nickel, and significant amounts of Iron, calctur, chloride, magnesium, silver, and cadniun to be present in the sludge. (S1licon and phosphorous could not be deternined by the nethod enployed.)

\subsubsection{Development of Inorganic Sorbents}

Screening tests Involving elghteen Inorganic sorbents were aade to evaluate thls ablity to renove cesfun and strontiun from aqueous systems. These tests identified a number of attractive candidate aterials, but the work did not proceed beyond the screening experiments in order to focus on some urgfnt issues which were Identifled in the course of the TMI-2 recovery operation.

\subsection{PUBLICATIONS}

None.

\subsection{REFERENCES}

None. 
INTERAAL DISTRIBUTION

1. T. L. Ashwood

2. J. F. Alexander

3. S. I. Auerbach

4. L. D. Bates

5. J. 0. Bloneke

6. H. D. Box

7. J. C. Brown

8. W. D. Burch

9. G. H. Burger

10. F. N. Case

11. H. R. Casto

12. J. H. Chandler

13. J. H. Coobs

14-15. H. S. Cooper

16. H. H. Cutshall

17. L. R. Dole

18. R. C. Durfee

19. I.. D. Eyman

20. D. E. Ferguson

21. R. B. Fitts

22. C. S. Fore

23. E. J. Frederick

24. H. Fulkerson

25. S. M. Gibson

26. J. R. Gissel

27. R. W. Glass

28. H. H. Godbee

29. T. Grizzard

30. K. W. Haff

31. B. A. Hannaford

32. P. B. Harrington

33. R. E. Helms

34. J. R. Hightower

35. D. D. Huff

36. P. E. Johnson

37. D. S. Joy

38. S. V. Raye

39. E. Y. Kimmerly

40. E. M. King

41. E. H. Krieg

42. H. J. Lackey

43. E. Lamb

44. L. C. Lasher

45. R. B. Leuze

46. R. S. Lowrie

47. T. S. Mackey

48. A. P. Malinauskas
49. R. C. Hay

50. B. H. McDantel

51. L. J. Mezga

52. H. S. Moran

53. J. H. Hapier

54. B. Newan

55. R. J. Hotz

56. T. H. Oakes

57. H. H. Pechin

58. T. H. Pickel

59. W. U. Pitt

60. D. E. Reichle

61. C. R. Richnond

62. J. J. Roddy

63. P. S. Rohwer

64. H. H. Rosenthal

65-67. T. H. Row

68. T. F. Scanlan

69. R. W. Schaich

70. C. D. Scott

71. J. D. Sease

72. L. B. Shappert

73. K. W. Somerfeld

74. H. G. Stewart

75. D. P. Stinton

76. L. H. Stinton

77. S. H. Stow

78. L. E. Stratton

79. J. H. Swanks

80. T. Tamura

81. T. N. Tiegs

82. D. B. Trauger

83. V. C. A. Vaughan

84. J. F. Walker, Jr.

85. G. C. Warlick

86. D. A. Webster

87. H. O. Weeren

88. J. R. Weir, Jr.

89. G. A. West

90. G. W. Westley

91. D. J. Wilkes

92. L. C. Williams

93. R. G. Hymer

94. ORLL Patent Oefice

95-96. Laboratory Records

97. Laboratory Records-RC 


\section{BXTERAAL DISTRIBUTION}

98. E. L. Albenesius, E. I. duPont de Memours \& Company, Savannah River Laboratory, P.0. Box A, Aiken, SC 29801

99. J. B. Baublitz, Division of Remedial Action Projects, U.S. Department of Bnergy, Ma1l Stop B-107, Nashington, DC 20545

100. R. H. Beers, Manager, Waste Programs Division, EG\&G Idaho, P.0. Box 1625, Idaho Palls, ID 83415

101. J. J. Blakeslee, Program Manager, Nuclear Naste Processing, Rockwell International, P.0. Box 464, Golden, CO 80401

102. L. G. Blalock, Chlef, Transportation Managesent Branch, Supply Division, U.S. Department of Energy, Oak Ridge Operations Office, P.0. Box E, Oak Ridge, TH 37830

103. R. A. Brown, Excon Nuclear, P.0. Box 2800, Idaho Palls, ID 83401

104. T. D. Chikalla, Battelle-Pacific Northwest Laboratory, Battelle Boulevard, P.0. Box 999, Richland, UA 99352

105. B. W. Church, Director, Health Physics Division, U.S. Department of Energy, Hevada Operations Office, P.0. Box 14100, Las Vegas, IN 89114

106. Dr. F. E. Coffman, Director, Office of Terminal Waste Disposal and Remedial Actions, Office of Nuclear Energy, U.S. Department of Energy, Mail Stop B-107, Washington, DC 20545

107. G. H. Daly, Technical Advisor, Deputy Assistant Secretary for Nuclear Materials, Defense Programs, U.S. Department of Energy, Ma11 Stop B-107, Washington, DC 20545

108-112. J. E. Dieckhoner, Director, Operations and Traffic Division, Office of Defense Waste and Byproducts Management, Defense Programs, U.S. Department of Energy, Mall Stop B-107, Hashington, DC 20545

113. R. L. Dintaman, WIPP Project Office, U.S. Department of Energy, Albuquerque Operations Office, P.0. Box 5400, Albuquerque, NM 87115

114. P. F. Dunigan, Jr., Low-Level Haste Management Program, Program Manager, U.S. Department of Energy, Richland Operations Office, P.0. Box 550, Richland, HA 99352

115. H. A. Frankhauser, Office of Defense Waste and Byproducts Management, Defense Programs, U.S. Department of Energy, Mall Stop B-107, Washington, DC 20545

116-118. C. Gertz, U.S. Department of Energy, Idaho Operations Office, 550 Second Street, Idaho Falls, ID 83401

119. R. V. Gilbert, Program Manager, Transuranics Waste Systems Office, Rockwell International Corporation, Rocky Plats Plant, P.0. Box 464, Golden, CO 80401

120. S. Goldsmith, Manager, Office of Waste Isolation, BattelleColumbus Laboratortes, 505 King Avenue, Columbus, OH 43201

121. F. P. Gorup, U.S. Department of Energy, Chicago Operations Office, 9800 South Cass Avenue, Argonne, IL 60439

;22. J. P. Hamric, Director, Nuclear Fuel Cycle and Waste Management Division, U.S. Department of Energy, Idaho Operations Office, 550 Second Street, Idaho Palls, ID 83401

123. E. Hennlly, U.3. Department of Energy, Savannah R1ver Laboratory, P.0. Box A, Alken, SC 29801

124. R. R. Jaeger, Manager, Nuclear Waste Technology, Monsanto Research Corporation, P.0. Br,x 32, M1amisburg, OH 45342 
125. R. M. Jefferson, Transportation Technology Center, Sandia National Laboratories, Department 4550, P.0. Box 5800, Albuquerque, M 87185

126-128. J. J. Jicha, Jr., Director, ReD and Byproducts Division, 0.S. Department of Bnergy, Mail Stop B-107, Hashington, DC 20545

129. E. L. Reller, Program Manager, FuSRAP, U.S. Department of Energy, Oak Ridge Operations Office, P.O. Box E, Oak Ridge, TI 37830

130. H. R. Kre!ter, Manager, Low-Level Waste Managenent Progran, Paciflc Northwest Laboratory, P.0. Box 999, RIchland, Wh 99352

131. W. J. Kyriazis, UxC-Nuclear Industries, Office of Surplus Facilities Managenent, P.0. Box 490, Richland, WA 99352

132. L. Lani, Project Manager, Nuclear and Magnetic Pusion Division, U.S. Department of Bnergy, San Francisco Operations Office, 1333 Broadway, Oakland, CA 94612

133. D. B. LeClaire, Deputy Director, Office of Defense Waste and Byproducts Management, Defense Programs, U.S. Department of Energy, Mail Stop B-107, Washington, DC 20545

134-138. J. L. Lenhard, Assistant Manager for Energy Research and Developirent, U.S. Department of Energy, Oak Ridge Operations Office, P.0. Box E, Oak Ridge, TN 37830

139. Dr. G. B. Levin, Program Manager, DOE Low-Level Waste Management Progran, BG\&G Idaho, P.0. Box 1625, Idaho Palls, ID 83415

140-144. R. Y. Lowrey, U.S. Department of Bnergy, Albuquerque Operations Office, P.0. Box 5400, Albuquerque, Ny 87115

145. W. J. Madia, Manager, Site Exploration, OCRD, Project Management Division, 505 King Avenue, Columbus, OH 43201

146. N. J. Magnani, Sandia National Laboratories, Department 5840, P.0. Box 5800 , Albuquerque, NM 87185

147. J. Malary, UMTRAP Office, U.S. Department of Energy, Albuquerque Operations Office, P.0. Box 5400, Albuquerque, NM 87115

148. S. A. Mann, Manager, Crystalline Rock Project Office, U.S. Department of Energy, Chicago Operations Office, 9800 South Cass Avenue, Argonne, IL 60439

149. B. F. Mastal, Manager, Planning Group, Division of Plans and Evaluations, U.S. Departmen'c of Energy, Mail Stop B-107, Hashington, DC 20545

150. D. J. McGoff, Head, Three Mile Island Project, Office of Nuclear Haste Management and Puel Cycle, U.S. Department of Energy, Mail Stop B-107, Washington, DC 20545

151. N. B. McLeod, NUS Corporation, 910 Clopper Road, Galthersburg, MD 20878

152. D. T. Oakley, Program Manager for Hast,e Management, Los Alamos National Laboratory, P.0. Box 1663, Los Alamos, MM 87545

153-157. Dr. G. K. Oertel, Director, Office of Defense Waste and Byproducts Management, U.S. Department of Energy, Ma1l Stop B-107, Hashington, DC 20545

158. K. 01liher, Transportation Program Manager, Haste Management and Transportation Division, U.S. Department of Energy, Albuquerque Operations Orfice, P.0. Box 5400, Albuquerque, MM 87115 
159. R. B. Pope, Transportation Systens Technolozy and Analysis, Division 9782, Transportation Technology Center, Sandia National Laboratories, P.0. Box 5800, Albuquerque, MA 87185

160. Beverly Rawles, Manager, Staff and Information Services, Battelle Menorial Institute, 505 King Arenue, Columbus, OA 43201

161. V. L. Sallor, Spectai Assistant to the Chairman for DOE LOWLevel Waste Prograns, Brookhaven Mational Laboratorles, Associated Universities Inc., Building 701, Opton, WY 11973

162. H. B. Saucier, Chier, Uaste Management Branch, Process and Veapons Division, U.S. Department of Bnergs, Savannah River Operations Orfice, P.0. Box A, Alken, SC 29801

163. J. J. Schreiber, Director, Uaste Management Division, $0 . S$. Depart cent of Energy, Richland Operations Office, 825 Jadwin Avenu' $=$, P.0. Box 550, Richland, WA 99352

164 L. J. Silth, TRU Waste Systens Orfice, Rockwell International Corporation, P.0. Box 464, Golden, CO 80401

165. R. E. Salth, Rockwell Hanford Operations, 2750 Bast Building, Roow D-264, P.0. Eox 800, Richland, Wh 99352

166. J. G. Steger, Environmental Sciences Group, Los Alanos Sclentiflc Laboratory, P.0. Box 1663 (LS-6), MS 495, Los Alawos, WA 87545

167-168. J. D. White, Director, Surplus Pacilities Managenent Program Office, U.S. Department of Energy, Richland Operations Office, P.0. Box 550, Richland, wh 99352

169. J. R. Wiley, Savannah River Laboratory, P.O. Box A, Aiken, SC 29801 